UNIVERSIDADE DE SÃO PAULO

INSTITUTO DE GEOCIÊNCIAS

\title{
O GREENSTONE BELT SAPUCAIA, MUNICÍPIO DE ÁGUA AZUL DO NORTE, PROVÍNCIA CARAJÁS: CARACTERIZAÇÃO PETROGRÁFICA E GEOQUÍMICA E IMPLICAÇÕES METALOGENÉTICAS
}

Soraya Damasceno Sousa

Orientadora: Prof ${ }^{a}$. Dr ${ }^{a}$. Lena Virgínia Soares Monteiro

\section{DISSERTAÇÃO DE MESTRADO}

Programa de Pós-Graduação em Recursos Minerais e Hidrogeologia

SÃO PAULO

2014 
UNIVERSIDADE DE SÃO PAULO

INSTITUTO DE GEOCIÊNCIAS

O GREENSTONE BELT SAPUCAIA, MUNICÍPIO DE ÁGUA AZUL DO NORTE, PROVÍNCIA CARAJÁS:

CARACTERIZAÇÃO PETROGRÁFICA E GEOQUÍMICA E IMPLICAÇÕES METALOGENÉTICAS

Soraya Damasceno Sousa

Orientadora: Prof ${ }^{a}$. Dr ${ }^{a}$. Lena Virgínia Soares Monteiro

\section{DISSERTAÇÃO DE MESTRADO}

Programa de Pós-Graduação em Recursos Minerais e Hidrogeologia

SÃO PAULO

2014 
Autorizo a reprodução e divulgação total ou parcial deste trabalho, por qualquer meio convencional ou eletrônico, para fins de estudo e pesquisa, desde que citada a fonte.

Ficha catalográfica preparada pelo Serviço de Biblioteca e Documentação do Instituto de Geociências da Universidade de São Paulo

Sousa, Soraya Damasceno

O Greenstone belt Sapucaia, município de Água Azul do Norte, Província Carajás: caracterização petrográfica e geoquímica e implicações metalogenéticas / Soraya Damasceno Sousa. -- São Paulo, 2014 .

185 p. : il. + apêndices + anexos

Dissertação (Mestrado): IGc/USP

Orient.: Monteiro, Lena Virgínia Soares

1. Rochas ultramáficas 2. Geoquímica 3. Província Carajás I. Título 


\section{AGRADECIMENTOS}

A conclusão desse trabalho, mesmo que não exatamente da forma como imaginei, foi possível com a ajuda de Deus e o incentivo de familiares, amigos e conhecidos.

Algumas pessoas deram sua contribuição muito além de suas tarefas diárias, por simples amizade ou gentileza; outras o fizeram como parte de suas atividades profissionais, pelo simples prazer de ensinar, com muita atenção e cordialidade - a todas essas pessoas, meu muito obrigada!

A minha família, pelo apoio incondicional, que desde o inicio os tirei da "zona de conforto", mas nunca duvidaram da minha certeza em concluir esse projeto - Mariana, Vanderley, Vanildo e Isabella.

A Dr ${ }^{\mathrm{a}}$ Lena Virgínia Monteiro Soares, que aceitou ser a orientadora deste trabalho, sempre muito atenciosa, me guiou por caminhos até então desconhecidos, mas que hoje são belos e fascinantes; participou de exatamente tudo, desde a escolha da área, da metodologia, dos trabalhos de campo, e sempre sugerindo, criticando, aconselhando e animando - qualquer agradecimento seria muito, mais muito pouco.

Ao Dr. Davis Carvalho de Oliveira, da Universidade Federal do Pará, primeiro a me incentivar a "aventurar em terras uspianas", acreditou na realização do trabalho e se dispôs a colaborar com que fosse preciso.

Ao Dr. Caetano Juliani, simplesmente pela amizade e pelo amor a geologia, muitas vezes conversou, orientou e discutiou sobre a geologia local e regional; pelos convites a campo, seja como monitora ou não, apenas para me mostrar uma geologia tão bela quanto a da Amazônia.

Ao Dr. Johann Hans Daniel Schorscher, que aceitou fazer parte da banca de qualificação e depois me recebeu várias vezes em sua sala, sempre com muita atenção, esclarecendo dúvidas, sugerindo, orientando, vendo lâminas, informando bibliografia e sempre deixando as portas abertas para uma volta.

Aos amigos que lá deixei..., porém sempre amigos - Jerffson, Fábio e Mariuza.

Aos meus colegas da pós-graduação, que nesses dois anos não mediram esforços para a realização de alguma etapa desta pesquisa. Entre eles, Carolina Moreto e Marcos Delinardo, da Unicamp, verdadeiros parceiros, participaram da etapa de campo e muito contribuíram com suas descrições e discussões; a Angela Veloso, pela ajuda nas preparações de amostras e pelas conversas sobre metamorfismo e mineralizações; a Claúdia Tokashiki, sempre disposta a ajudar em tudo, qualquer obrigado seria simples demais, pois desde a companhia para almoçar até as crises de dor de cabeça, ela sempre esteve presente; ao incansável Carlos Mário Misas, ao Ivan Marques, Natali Barbosa, Alexandra Aguja, Geane Cavalcante e 
Gustavo Viegas; aos membros e coordenador do grupo Evolução Crustal e Metalogênese em Carajás, professor Roberto Xavier...Obrigada!

Finalmente, a CAPES, financiadora da bolsa de pesquisa; ao INCT- Geociam (Proc.: 573733/2008-2) / Edital 01/2010 ICAAF 053/2011 Convênio VALE/FAPESPA, pelo apoio financeiro e ao Programa de Recursos Minerais e Hidrogeologia da Universidade de São Paulo, pelo auxílio. 


\section{RESUMO}

O Grupo Sapucaia, localizado no sudeste do Cráton Amazônico, na Província Mineral de Carajás, entre os Domínios Carajás e Rio Maria, repreenta uma sequência supracrustal provavelmente de idade mesoarqueana. Essa unidade ocorre como lentes descontínuas, imbricadas nas rochas do embasamento ao longo de zonas de cisalhamento de direção E-W a NW-SE, interceptadas por falhas rúpteis com variadas direções (N/S - NE/SW). Foram reconhecidas no Grupo Sapucaia, unidades metaultramáficas, metabásicas e metassedimentares, além de corpos gabroicos e granitoides variados. Nas unidades metaultramáficas predominam amplamente (antofilita)-tremolita-clorita xistos, constituídos por clorita magnesiana do tipo clinocloro e tremolita, geralmente substituída em suas bordas por antofilita, além de porfiroblastos de magnetita e cristais de ilmentita. Os demais litotipos são representados por serpentinitos, constituídos por lizardita com textura em rede associada a pseudomorfos de olivina (forsterita) intensamente intemperizados e limonitizados. Esse litotipo apresenta vestígios de texturas ígneas cumuláticas do protólito. Outros litotipos metaultramáficos incluem talco-clorita xisto; (talco)-clorita-cummingtonita xisto e magnetita clorititos, além de hercinita-olivina-clorita-hornblenda xisto. Os (talco)-clorita-cummingtonita xisto apresenta conteúdo de $\mathrm{MgO}>30 \%$, característico de rochas cumuláticas (olivine cumulates) comumente associada aos derrames ultramáficos. Os magnetita clorititos resultam de alteração do tipo black wall associada a processos metassomáticos ao longo do contato tectônico entre as rochas metaultramáficas e os granitoides. Os litotipos metaultramáficos apresentam paragênese metamórfica compatível com condições de fácies xisto verde superior a anfibolito inferior. As rochas metaultramáficas menos metassomatisadas (antofilita-cloritatremolita xistos) possuem semelhanças geoquímicas com komatiítos do tipo Barberton com elevadas razões de $\mathrm{Gd} / \mathrm{Yb}_{\mathrm{N}}(1,31$ a 3,46), indicativas de formação a partir de magmas resultantes de elevadas taxas de fusão do manto peridotítico com majorita no resíduo. Suas significativas anomalias positivas de $\mathrm{Nb}$ evidenciam derivação de plumas mantélicas com contribuição de material do slab reciclado em grandes profundidades. Razões entre elementos HFS indicam para tais litotipos semelhança com basaltos de ilha oceânica (OIB) transicionais para MORB. A assinatura química distinta dos antofilita-Mg-cummingtonita xistos (baixo conteúdo de ETR, razões $\mathrm{Gd} / \mathrm{Yb}_{\mathrm{N}}$ mais baixa e anomalias negativas de $\mathrm{Nb}$ ) não pode ser atribuída apenas à contaminação crustal ou metassomatismo e é sugestiva de derivação de pluma heterogênea com múltiplos componentes. Adicionalmente, corpos de olivina-hercinitaclorita-(Mg) hornblenda xisto com olivina fortemente estirada revelam deformação dúctil de alta temperatura em condições de fácies anfibolito superior a granulito, refletindo trajetória metamórfica distinta das demais unidades atribuídas ao Greenstone Belt Sapucaia. A 
semelhança desses litotipos com peridotitos do manto superior, mais comumente associados a sequências ofiolíticas desmembradas, e a associação espacial com limite de domínios tectônicos, pode sugerir associação com antiga zona de sutura. Os metabasitos são representados por hornblenda anfibolitos, variavelmente foliados, granoblásticos e com textura porfiroblástica. As rochas metabásicas apresentam conteúdos de $\mathrm{SiO}_{2}(49,81 \%$ a $52,67 \%), \operatorname{MgO}\left(7,69\right.$ a 16,14\%) e $\mathrm{Na}_{2} \mathrm{O}+\mathrm{K}_{2} \mathrm{O}(1,28$ a 2,45\%) semelhantes à de basaltos e andesitos basálticos tholeiíticos formados em ambiente MORB. A unidade metassedimentar é constituída por (granada)-muscovita-biotita xistos com textura lepidoblástica e cristais de almandina estirados. Corpos gabroicos com orientações variadas (NE-SW, NW-SE e N-S) e caráter isotrópico também foram reconhecidos. O contato do Greenstone Belt Sapucaia com unidades granito-gnáissico-migmatíticas é marcado por extensas zonas de cisalhamento, com trend preferencial E - W. Esses granitoides incluem: (a) anfibólio (hornblenda)-biotita granito foliado; (b) biotita leucogranito; e (c) biotita gnaisses de composição trondjemítica ou granodiorítica, variavelmente migmatizados e milonitizados. Os biotita gnaisses e o biotita leucogranito apresentam assinatura típica de suítes TTG formadas a partir de magmas resultante da fusão de metabasaltos hidratados a pressões elevadas (acima de 12 kbar), compatíveis com estabilidade da granada e anfibólio no resíduo. O anfibólio (hornblenda)biotita granito foliado difere dos demais por sua semelhança geoquímica com granitos do tipo A, formados em ambiente intra-placa de forma análoga aos granitos alcalinos neoarqueanos da Suíte Planalto, caracterizado apenas no Domínio Carajás. Assim, o conjunto de litotipos caracterizados na área de Água Azul do Norte pode registrar resquícios de platôs ou ilhas oceânicas, representados pelas unidades do Greenstone Belt Sapucaia, amalgamados ao protocontinente constituído pelas unidades TTG, atribuídas ao Complexo Xingu, possivelmente durante o Mesoarqueano. 


\section{ABSTRACT}

The Sapucaia Group, located in the southeastern portion of the Amazonian Craton, in the Carajás Mineral Province, between the Carajás and Rio Maria domains, represents a supracrustal sequence, possibly Mesoarchean in age. The Sapucaia Group occurs as discontinuous lenses, imbricated in the basement rocks within EW- or NW-trending ductile shear zones, and are usually cut by brittle structures with different directions (N/S - NE/SW). Metaultramafic, metabasic, and metasedimentary units have been recognized, as well as gabbroic bodies and a variety of granitoids. In the metaultramafic unit, (anthophyllite)tremolite-chlorite schist predominates. It is composed of magnesian chlorite and tremolite, which is replaced along crystal rims by anthophyllite, and subordinate porphyroblasts of magnetite and ilmenite. Serpentine consisting of lizardite with mesh texture and olivine pseudomorphs, which were heavily weathered to limonite, was also recognized. It reveals remnants of pre-existing cumulate textures of the protholith. Other metaultramafic rocks comprise talc-chlorite schist, (talc)-chlorite-cummingtonite schist, magnetite chloritites, and olivine-hercinite-chlorite-hornblende schist. The (talc)-chlorite-cummingtonite schist has $\mathrm{MgO}$ content $>30 \%$ and exhibits characteristics of cumulate rocks (olivine cumulates), commonly associated with ultramafic flows. The magnetite chloritites resulted from black wall alteration associated with metasomatic processes within the tectonic contacts between the granitoid and metaultramafic rocks. The least-metasomatised metaultramafic rocks (anthophyllite-chlorite-tremolite schists) are similar to Barbenton-type komatiites. They have high $\mathrm{Gd} / \mathrm{Yb}_{\mathrm{N}}$ ratios (1.31 to 3.46), which are indicative of protholith formation from magmas resulting from high melting rates of the peridotitic mantle with majorite in the residue. Significant positive $\mathrm{Nb}$ anomalies suggest derivation of mantle plumes with contribution of recycled slab material at great depths. HFS element ratios indicate similarity of these rocks with oceanic island basalts (OIB) transitional to MORB. The distinct chemical signature of the Mg-anthophyllite-cummingtonite schist (low REE contents, lower $\mathrm{Gd} / \mathrm{Yb}_{\mathrm{N}}$ ratios, and negative $\mathrm{Nb}$ anomalies) cannot be attributed only to crustal contamination or metasomatism and is suggestive of derivation of heterogeneous multicomponent plume. Additionally, the olivine-hercinite-chlorite-( $\mathrm{Mg})$ hornblende schist with strongly stretched olivine reveals high temperature ductile deformation in conditions of the upper amphibolite to granulite facies, reflecting distinct metamorphic trajectory in relation to the other units assigned to the Sapucaia Greenstone Belt. This lithotype is similar to the upper mantle peridotites, commonly associated with dismembered ophiolite sequences. Its spatial association with the tectonic boundary between the two domains of the Carajás Province may suggest association with an ancient suture zone. The metabasites are represented by hornblende amphibolite, which is 
variably foliated, showing granoblastic and porfiroblastic texture. The metabasic rocks have $\mathrm{SiO}_{2}(49.81 \%$ to $52.67 \%), \mathrm{MgO}$ (7.69 to $16.14 \%$ ) and $\mathrm{Na}_{2} \mathrm{O}+\mathrm{K}_{2} \mathrm{O}$ (1.28 to $2.45 \%$ ) contents similar to those of tholeiitic basalt and basaltic andesites formed in MORB environment. The metasedimentary unit comprises (garnet)-muscovite-biotite schist with lepidoblastic texture and stretched almandine porphyroblasts. Gabbro bodies with different orientations (NE-SW, NW-SE and NS) and isotropic character have been also identified. The tectonic contact between the Sapucaia Greenstone Belt and the granite-gneiss-migmatitic terrain is marked by extensive shear zones with preferential E-W trend. These granitoids include: (a) foliated amphibole (hornblende)-biotite granite; (b) biotite leucogranite; (c) biotite gneisses with trondhjemitic or granodioritic composition, which have been variably migmatized and mylonitized. The biotite leucogranite and the biotite gneisses have geochemical signature typical of TTG-type suites derived from magmas generated by melting of hydrated metabasalts in conditions of high pressures (above $12 \mathrm{kbar}$ ), which are consistent with stability of garnet and amphibole in the residue. The foliated amphibole (hornblende)biotite granite is similar to A-type granites formed in intra-plate environment and shares characteristics with the widespread Neoarchean granite magmatism represented by the Planalto suite, which was characterized only in the Carajás Domain.Thus, the set of lithologies in the Água Azul do Norte area can register remnants of plateaus or oceanic islands (Greenstone Belt Sapucaia) amalgamated to the proto-continent, which is represented by TTG orthogneisses attributed to the Xingu Complex, possibly during the Mesoarchean. 


\section{LISTA DE FIGURAS}

Figura 1. Mapa de localização da área de estudo: A) localização da área no contexto do Estado do Pará; e B) principais vias de acesso no contexto regional (modificado de Leite 2004).

Figura 2. Modelo de geração dos Greenstones belts devido à progradação arco-fossa (Hoffman,1990).

Figura 3. Extrusão de magma ultramáfico por extensão e posterior acrescão ao continente. (Barth 2007). 30

Figura 4. Modelos tectônicos para formação de greenstone belts. a) Modelos de formação de greenstone belts baseado no processo de sagducção; b) Modelo de formação de greenstone belt devido à tectônica de acresção (Neves 2001). 30

Figura 5. Estratigrafia simplificada de uma sequência greenstone belt, mostrando derrames komatiíticos na base, rochas vulcânicas máficas a félsicas e rochas sedimentares no topo (Condie 1981).

Figura 6. Secção estratigráfica geral para as associações arqueanas (De Wit \& Ashwal 1997).

Figura 7. Províncias geocronológicas do Cráton Amazonas de acordo com as propostas de a) Tassinari \& Macambira (2004), e b) Santos et al. (2006).

Figura 8. (A) Localização da Província Carajás no Estado do Pará; (B) Divisão da Província Carajás nos Domínios Rio Maria (DRM), ao sul, e Carajás (DC), que é limitado ao norte pelo Domínio Bacajá (DB); (C) Mapa geológico do Domínio Rio Maria (modificado de Vasquez et al. 2008b e Almeida et al. 2011).... 39

Figura 9. Mapa geológico do Domínio Carajás (Vasquez et al. 2008b). 47

Figura 10. a) Localização da Província Carajás no Cráton Amazônico, modificado de Tassinari \& Macambira (1999); b) Mapa geológico da Província Carajás, modificado de Vasquez et al. (2008b), Almeida (2010) e Feio et al. (2012). 52

Figura 11. 1) Modo de ocorrência das rochas metaultramáficas em blocos in situ e rolados; 2) rocha metaultramáfica intensamente intemperizada com relíquia de possíveis pseudomorfos de cristais de olivina e foliação metamórfica; 3) foliação milonítica em rocha metaultramáfica, 4) variedade litológica das rochas ultramáficas pertencentes ao Grupo Sapucaia, representada por Mg-clorita-tremolita xistos com porfiroblastos idiomórficos de magnetita. .....

Figura 12. Feiçoes estruturais caracterizadas na área de estudo: 1) foliação milonítica em biotita granodiorito, com presença de porfiroclastos de quartzo e plagioclásio; 2) bandamento composicional representado por bandas quartzo-feldspática e por bandas de minerais máficos em gnaisses; 3) dobras assimétricas em migmatito (metatexito estromático); 4) foliação milonítica em zona de cisalhamento, no contato entre os granitoides e as rochas do Grupo Sapucaia; 5) foliação milonítica e dobramento de veios de quartzo em biotita granodiorito cisalhado; 6) fraturas e vênulas preenchidas com quartzo em dique de rocha máfica; 7) injeções pegmatíticas em biotita tonalito; 8) clivagem de crenulação bem desenvolvida nas rochas metaultramáficas (tremolita-Mg-clorita xistos).

Figura 13. Mapa de localização dos pontos amostrados sobrepostos ao mapa geológico da região de Água Azul do Norte de Araújo \& Maia (1991).

Figura 14. (1) Modo de ocorrência dos serpentinitos foliados; (2) Detalhe da amostra de serpentinito, mostrando a granulação fina dos litotipos mais preservados; (3) amostra de serpentinito com pseudomorfos de olivina e calcedônia ao longo de planos de foliação, 
fraturas e descontinuidades; (4) detalhe dos cristais parcialmente preservados de olivina, e sua substituição por limonita (fotomicrografia em luz transmitida; polarizadores cruzados); (5), (6) e (7) textura em rede, na qual os canais são preenchidos por serpentina e calcedônia, com alguns cristais de magnetita associados (fotomicrografia em luz transmitida; polarizadores cruzados); e (8) detalhe dos cristais de magnetita subeuhedrais associados com lizardita (fotomicrografia em luz transmitida; polarizadores descruzados). Abreviações: Cld = Calcedônia; $\mathrm{Mag}=$ magnetita $; \mathrm{Ol}=$ olivina $; \mathrm{Srp}=$ serpentina .

Figura 15. (1) Modo de ocorrência, geralmente em blocos rolados ou pequenos lajedos, do talco xisto; (2) detalhe da amostra de talco xisto com clivagem de crenulação bem desenvolvida; (3) talco xisto crenulado com foliação $\mathrm{Sn}$ localmente transposta pela foliação $\mathrm{Sn}+1$, ao longo da qual orientam-se cristais de magnetita (fotomicrografia em luz transmitida, polarizadores cruzados); (4) Idem com polarizadores descruzados; (5) talco xisto com magnetita alinhada no plano da clivagem de crenulação (fotomicrografia em luz transmitida, polarizadores cruzados); (6) Idem com polarizadores descruzados. Abreviações: $\mathrm{Chl}=$ clorita; Mag = magnetita; Tlc $=$ talco.

Figura 16. (1) modo de ocorrência em blocos rolados dos antofilita-clorita-tremolita xistos; e (2) detalhe macroscópico dos antofilita-clorita-tremolita xistos, mostrando sua textura fina e foliação bem desenvolvida.

Figura 17. Fotomicrografias em luz transmitida e polarizadores cruzados dos antofilita-cloritatremolita xistos. (1) porfiroblasto de antofilita em meio a matriz constituída por clorita e tremolita; (2) cristal prismático de ortoanfibólio (antofilita) com extinção reta; (3) porfiroblastos de tremolita, com bordas alteradas, possivelmente para antofilita, com talco em sua volta, provavelmente decorrente da desestabilização da tremolita; e (4) porfiroblastos de tremolita com bordas alteradas. Abreviações: Ath = antofilita; $\mathrm{Chl}=$ clorita; $\mathrm{Tlc}=$ talco; $\mathrm{Tr}=$ tremolita.

Figura 18. (1) Imagem de elétrons retro-espalhados obtida em microscopia eletrônica de varredura (MEV) mostrando as relações de contato entre os anfibólios. Notar que geralmente a antofilita ocorre nas bordas e nos planos de fraqueza dos cristais de tremolita, substituindoa. A imagem mostra também a presença de ilmenita e pequena inclusão de pirrotita na tremolita; (2) cristal de tremolita substituído por antofilita e opacos tanto no centro como nas bordas (luz transmitida; polarizadores cruzados); e (3) presença significante de carbonato (magnesita?) nas rochas dessa unidade (luz transmitida; polarizadores cruzados). Abreviações: Ath = antofilita; Clc = clinocloro; Ilm = ilmenita; Mag = magnetita; Mgs = magnesita; $\operatorname{Prr}=$ pirrotita; $\operatorname{Tr}=$ tremolita.

Figura 19. (1) Modo de ocorrência, geralmente em pequenos blocos rolados, do cummingtonita-magnetita-clorita-tremolita xisto; (2) detalhe da clivagem de crenulação em amostra de cummingtonita-magnetita-clorita-tremolita xisto; (3) cristais prismáticos de tremolita associada a magnetita parcialmente limonitizada (fotomicrografia em luz transmitida; polarizadores cruzados); (4) rocha constituída predominantemente por tremolita, com rara ocorrência de $\mathrm{Mg}$-cummintonita em sua borda (fotomicrografia em luz transmitida; polarizadores cruzados); (5) cristal de tremolita substituído parcialmente por clorita (no centro, bordas e fraturas) e por talco em sua borda (fotomicrografia em luz transmitida; polarizadores cruzados); (6) clorita magnesiana, associada à magnetita, orientada no plano da foliação Sn e clivagem de crenulação (fotomicrografia em luz transmitida; polarizadores cruzados). Abreviações: $\mathrm{Clc}=$ clinocloro; $\mathrm{Lim}=$ limonita; $\mathrm{Mag}=$ magnetita; $\mathrm{Mgcm}=$ magnésio-cummingtonita; $\mathrm{Tlc}=$ talco; $\mathrm{Tr}=$ tremolita

Figura 20. (1) Imagem de elétrons retro-espalhados obtida por microscopia eletrônica de varredura (MEV) mostrando as feições texturais entre os diferentes anfibólios no cummingtonita-magnetita-clorita-tremolita xisto. A Mg-cummingtonita substitui os cristais de 
tremolita, principalmente nas suas bordas. Também podem ser observadas na imagem a clorita associada com os cristais de tremolita e magnetita euhédrica a subeuhedral; (2) cristais de tremolita intercrescida à magnetita, e presença de limonita como produto de alteração da magnetita (imagem de elétrons retro-espalhados); (3) cristal de magnetita com exsolução de ilmenita nos planos de fraqueza. Abreviações: Clc = clinocloro; Ilm = ilmenita; Lm = limonita $;$ Mag = magnetita $;$ Mgcm = magnésio-cummingtonita $; \operatorname{Tr}=$ tremolita . 70

Figura 21. Aspectos petrográficos dos clorita-(Mg)cummingtonita xistos. (1) Raros cristais de tremolita, parcialmente alterados ao longo de suas bordas, em meio aos cristais de $\mathrm{Mg}$ cummingtonita e clorita; (2) talco retrometamórfico substituindo a cummingtonita; (3) cristais hipidiomórficos de clorita, com maclas bem definidas; e (4) arranjo de cristais de Mgcummingtonita, exibindo textura decussada, juntamente com clorita e talco. Fotomicrografias em luz transmitida e polarizadores cruzados. Abreviações: $\mathrm{Chl}=$ clorita; $\mathrm{Mag}=$ magnetita; $\mathrm{Mgcm}=\mathrm{Mg}$-cummingtonita; $\mathrm{Tl} \mathrm{c}=$ talco $; \mathrm{Tr}=$ tremolita.

Figura 22. Aspectos petrográficos dos clorita-actinolita xistos. (1) Clivagem de crenulação em clorita-actinolita xisto com alguns porfiroblastos de actinolita alterados pelo intemperismo; (2) e (3) cristais porfiroblásticos de actinolita envoltos por clorita e cristais prismáticos e finos de actinolita (luz transmitida, polarizadores cruzados); (4) cristal de actinolita com bordas alteradas (luz transmitida, polarizadores cruzados); (5) porfiroblastos de actinolita com inclusão de magnetita (luz transmitida, polarizadores cruzados) e (6) cristais de magnetita estirados e alinhados no plano da foliação (luz transmitida, polarizadores descruzados). Abreviações: Act $=$ actinolita $; \mathrm{Chl}=$ clorita; $\mathrm{Mag}=$ magnetita .

Figura 23. (1) Amostra de edenita-clorita xisto com foliação bem desenvolvida; (2) Edenita com baixa cor de interferência e clorita magnesiana orientadas ao longo do plano de foliação Sn (luz transmitida, polarizadores cruzados); (3) detalhe da textura lepidonematoblástica, com anfibólio e clorita alinhados no plano da foliação (luz transmitida, polarizadores cruzados); (4) magnetita parcialmente dissolvida e com corrosão nas bordas e no centro (luz transmitida, polarizadores descruzados). Abreviações: $\mathrm{Chl}=$ clorita; $\mathrm{Ed}=$ edenita; $\mathrm{Mag}=$ magnetita. ..... 74

Figura 24. (1) Clorita-fluoroedenita xisto com brilho sedoso e xistosidade bem desenvolvida; (2) cristais de fluoroedenita com bordas alteradas, possivelmente substituídas por antofilita (luz transmitida, polarizadores cruzados); (3) Talco associado à magnetita em cloritafluoroedenita xisto (luz transmitida, polarizadores cruzados); (4) cristal de magnetita subeuhedral associada ao anfibólio e à clorita (nimita) (luz transmitida, polarizadores descruzados). Abreviações: $\mathrm{Chl}=$ clorita; $\mathrm{Fle}=$ fluoroedenita; $\mathrm{Mag}=$ magnetita; Tlc $=$ talco.

Figura 25. (1) Modo de ocorrências dos clorititos, em blocos; (2) amostra de cloritito com porfiroblastos idiomórficos de magnetita; (3) aspecto geral ao microscópio, com cristais de clorita fortemente pleocróica, orientados segundo o plano da foliação $\mathrm{Sn}$, com a presença de cristais de apatita com cor de baixa birrefringência (luz transmitida, polarizadores cruzados); (4) resquício de biotita em meio aos cristais de clorita (luz transmitida, polarizadores cruzados); (5) imagem de luz refletida dos cristais alongados de ilmenita e pequeno cristal de zircão com halo pleocróico; (6) Imagem de elétrons retro-espalhados obtida por microscopia eletrônica de varredura (MEV) de cromomagnetita, na qual é possível observar as bordas mais ricas em cromo; (7) Imagem de elétrons retro-espalhados obtida por microscopia eletrônica de varredura (MEV) de cristal de magnetita com exsolução de ilmenita no centro dos cristais e substituição por ilmenita e rutilo nas bordas e nos planos de fraqueza e (8) imagem de elétrons retro-espalhados mostrando cristais de zircão, monazita e apatita, comuns nos clorititos. Abreviações: $\mathrm{Ap}=$ apatita; $\mathrm{Bt}=$ biotita $; \mathrm{Clc}=$ clinocloro $; \mathrm{Chmg}=$ cromomagnetita $; \mathrm{Cst}=$ crisotila; Ilm = ilmenita; Mag = magnetita; $\mathrm{Mnz}=$ monazita $; \mathrm{Rt}=$ rutilo; $\mathrm{Zr}=$ zircão. 
Figura 26. (1) Amostra de olivina-hercinita-clorita-(Mg) hornblenda xisto na qual é possível a observação dos cristais de olivina intensamente estirados e alterados pelo intemperismo, resultando em sua cor ocre; (2) relação de contato entre os cristais Mg-hornblenda, geralmente poligonal, no plano da foliação (luz transmitida, polarizadores cruzados); (3) e (4) olivina, limonitizada, com cor avermelhada, orientada e fortemente estirada, cortada e/ou substituída por clorita magnesiana e serpentina (luz transmitida, polarizadores cruzados); (5) Hercinita (verde) associada ao cristais de olivina (luz transmitida, polarizadores descruzados); (6) imagem de elétrons retro-espalhados obtida por microscopia eletrônica de varredura (MEV) onde observa-se a serpentina nas bordas da olivina, ripas de clorita discordante a foliação, cristais de cromomagnetita e magnetita. Abreviações: Clc = clinocloro; $\mathrm{Chmg}=$ cromomagnetita; Hc = hercinita; Mag = magnetita; $\mathrm{Mhb}=$ Mg-horblenda; $\mathrm{Ol}=$ olivina; $\mathrm{Srp}=$

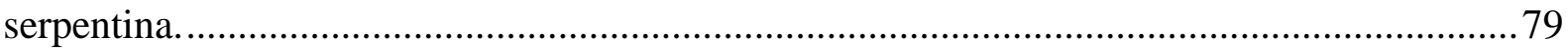

Figura 27. (1) Mg-hornblenda anfibolito foliado e com segregação metamórfica entre minerais máficos e félsicos; (2) aspecto geral da rocha com arranjo granoblástico a decussado; luz transmitida e polarizadores cruzados; (3) porfiroblastos de hornblenda com finas inclusões de quartzo orientadas, indicando geração sin a pós-cinemática em relação à $\mathrm{Sn}-1$, que teria sido transposta pela Sn; luz transmitida e polarizadores cruzados; (4) cristais de Mghornblenda em forma fibro-radiado e estrutura do tipo arco poligonal; luz transmitida e polarizadores cruzados; (5) porfiroblastos de hornblenda com inclusão de outros cristais de hornblenda e quartzo; luz transmitida e polarizadores cruzados; (6) turmalina associada aos cristais de anfibólio; luz transmitida e polarizadores descruzados; (7) segregação metamórfica entre máficos e félsicos; luz transmitida e polarizadores cruzados; (8) Detalhe da primeira geração de plagioclásio, texturalmente mais grosso; luz transmitida e polarizadores cruzados. Abreviações: $\mathrm{Hbl}=$ hornblenda; $\mathrm{Pl}$ = plagioclásio; $\mathrm{Qz}=$ quartzo; Tur = turmalina. 81

Figura 28. (1) Modo de ocorrência do hornblenda anfibolito, geralmente em blocos rolados; (2) detalhe da rocha, mostrando finos cristais de hornblenda; (3) presença de hornblenda, plagioclásio e quartzo no hornblenda anfibolito (luz transmitida e polarizadores cruzados); (4) relação de contato entre os cristais de hornblenda, alguns dos quais parcialmente alterados (luz transmitida e polarizadores cruzados); (5) relação de contato regular e reto entre cristais de hornblenda (luz transmitida e polarizadores cruzados); (6) possível magnetita com feição de dissolução nas bordas e partes centrais (luz transmitida e polarizadores descruzados). Abreviações: $\mathrm{Hbl}$ = hornblenda; $\mathrm{Pl}$ = plagioclásio; Qz = quartzo; Mag = magnetita.

Figura 29. (1) modo de ocorrência do muscovita-biotita xisto com granada em afloramento extenso; (2) xistosidade bem desenvolvida e crenulada do muscovita-biotita xisto; (3) cristais de muscovita em textura lepidoblástica definindo uma foliação espaçada (luz transmitida, polarizadores cruzados); (4) cristal de almandina subeuhedral com biotita em suas bordas, com foliação interna Sn-1, discordante da foliação externa, $\mathrm{Sn}$, da rocha (luz transmitida, polarizadores cruzados); (5) cristais de muscovita e biotita arqueados, com textura lepidoblástica (luz transmitida, polarizadores descruzados); (6) cristais de quartzo em textura bulging entre si, extinção ondulante e contato poligonal; ao centro, cristal de allanita com halo pleocróico (luz transmitida, polarizadores cruzados); (7) imagem de elétrons retro-espalhados obtida por microscopia eletrônica de varredura (MEV) na qual é possível observar lamelas de ilmenita e hematita na biotita; (8) inclusões de quartzo vermicular no plagioclásio (luz transmitida, polarizadores cruzados). Abreviações: $\mathrm{Alm}=$ almandina; $\mathrm{Aln}=$ alanita; $\mathrm{Bt}=$ biotita $; \mathrm{Chl}=$ clorita $;$ Hem = hematita Ilm = ilmenita; $\mathrm{Ms}=$ muscovita; $\mathrm{Qz}=$ quartzo.......... 85

Figura 30. (1) aspecto das rochas metavulcanoclástica com cor avermelhada e variegada; (2) cristais de clorita alongados, orientados no plano da foliação (luz transmitida, polarizadores descruzados); (3) possivelmente cristal de magnetita, que foi deformado e orientada, envolto por finos cristais de clorita e grãos de quartzo (luz transmitida, polarizadores cruzados); (4) quartzo que possivelmente representa níveis de chert metamorfisado e cisalhado (luz 
transmitida, polarizadores cruzados). Abreviações: $\mathrm{Chl}=$ clorita; Mag = magnetita; $\mathrm{Qz}=$

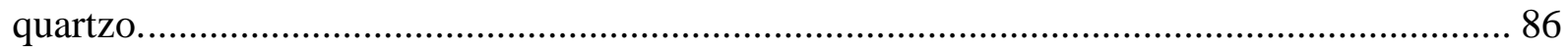

Figura 31. (1) Aspecto macroscópico do gabro, representado por rocha mesocrática, grossa e isotrópica; (2) cristais de hornblenda intersticiais e plagioclásio ripiforme em gabro; (3) cristal de clinopiroxênio com baixa birrefringência (piogenita); (4) cristal de hornblenda, associada ao clinopiroxênio (luz transmitida e polarizadores cruzados). Abreviações: $\mathrm{Hb}=$ hornblenda; Pgt = piogenita $; \mathrm{Pl}=$ plagioclásio . 88

Figura 32. (1) Afloramento in situ do Biotita Gnaisse Granodiorítico, localmente migmatítico, no qual o bandamento composicional é bem evidente; (2) amostra macroscópica mostrando os megacristais de microclínio; (3) cristal de microclínio com inclusão de quartzo e plagioclásio; (4) megacristal de plagioclásio, cujas fraturas foram preenchidas por quartzo recristalizado; (5) cristal de ortoclásio com inclusão de quartzo; (6) cristais de epidoto em associação com a biotita; (7) cristal de plagioclásio com encurvamento dos planos da geminação e (8) muscovita em associação com a biotita (luz transmitida e polarizadores cruzados). Abreviações: $\mathrm{Bt}=$ biotita; $\mathrm{Ep}=$ epidoto; $\mathrm{Mc}=$ microclínio $; \mathrm{Ms}=$ muscovita; $\mathrm{Pl}=$ Plagioclásio; $\mathrm{Or}=$ ortoclásio; $\mathrm{Qz}=$ quartzo.....

Figura 33. (1) Modo de ocorrência em lagedo de migmatito metatexítico estromático e dobrado; (2) mesossoma com diopsídio com textura simplectítica, com inclusões vermiculares de quartzo; (3) epidoto e quartzo com textura simplectítica; (4) aspecto geral do mesossoma, com cristais de plagioclásio, quartzo, biotita e epidoto; (5) textura simplectítica formada por anfibólio, epidoto e clinopiroxênio com inclusões de quartzo, sendo que a biotita substitui o anfibólio; (6) cristal de plagioclásio geminado com sericitização seletiva e inclusão de quartzo; (7) associação entre biotita e opacos (magnetita?) e (8) associação de biotita, anfibólio e epidoto. Fotomicrografias de 37-2 a 37-6 foram feitas a luz transmitida e polarizadores cruzados; fotos 37-7 e 37-8 sob luz transmitida e polarizadores descruzados. Abreviações: $\mathrm{Amp}=$ anfibólio; $\mathrm{Bt}=$ biotita $; \mathrm{Cpx}=$ clinopiroxênio; $\mathrm{Ep}=$ epidoto; $\mathrm{Mag}=$ magnetita; $\mathrm{Pl}=$ Plagioclásio; $\mathrm{Qz}=$ quartzo

Figura 34. (1) Detalhe do biotita granodiorito gnaisse em amostra de mão; (2) detalhe da foliação anastomosada, milonítica, e porfiroclastos de plagioclásio; (3) detalhe do encurvamento dos planos de geminação do plagioclásio; (4) quartzo recristalizado, em subgrãos e com extinção fortemente ondulante; (5) clinozoisita com textura simplectítica e (8) cristais de titanita em associação com biotita (luz transmitida e polarizadores cruzados). Abreviações: $\mathrm{Bt}=$ biotita; $\mathrm{Ep}=$ epidoto; $\mathrm{Mc}=$ microclínio; $\mathrm{Pl}=$ plagioclásio; $\mathrm{Qz}=$ quartzo; Ttn = titanita.

Figura 35. (1) Aspecto geral do gnaisse granodiorítico milonitizado com veios de quartzo, por vezes dobrados; (2) detalhe da foliação milonítica e dos porfiroclastos de plagioclásio; (3) faixa contínuas de biotita, cujo espaço microlítico é composto por quartzo recristalizado; (4) plagioclásio com geminação apertada, pouco desenvolvida; (5) cristal de allanita envolvido por epidoto, em associação com cristais de biotita e (6) fotomicrografia mostrando faixas de biotita. Fotomicrografias de 40-1 a 40-5 em luz transmitida e polarizadores cruzados e 40-6 com luz transmitida e polarizadores descruzados. Abreviações: Aln = allanita; $\mathrm{Bt}=$ biotita; $\mathrm{Pl}$ $=$ plagioclásio $; \mathrm{Qz}=$ quartzo; $\mathrm{Ttn}=$ titanita.

Figura 36. (1) Bloco rolado de hornblenda-biotita granito foliado, com enclaves de rocha máfica; (2) veios de quartzo em hornblenda-biotita granito foliado; (3) megacristal de plagioclásio, cujas fraturas estão preenchidas por quartzo recristalizado; (4) epidotoem fraturas; (5) hornblenda em associação com biotita e titanita; (6) cristais de hornblenda com inclusão de biotita e titanita; (7) biotita orientada no plano da foliação, em associação com epidoto e titanita e (8) megacristal de ortoclásio com pequenas inclusões de epidoto. Fotomicrografias feitas sob luz transmitida e polarizadores cruzados. Abreviações: Amp = 
anfibólio; $\mathrm{Bt}=$ biotita; $\mathrm{Ep}=$ epidoto $\mathrm{Pl}=$ Plagioclásio; Or = ortoclásio; Ttn = titanita; $\mathrm{Qz}=$ quartzo.

Figura 37. (1) Aspecto macroscópico do biotita leucogranito com textura fanerítica média e sutil alinhamento da biotita segundo uma orientação preferencial; (2) megacristais de microclínio e matriz com predominância de quartzo recristalizado; (3) megacristal de plagioclásio com geminação apertada, fraturas preenchidas por quartzo e bordas corroídas; (4) cristal de ortoclásio hipidiomórfico com pertitas, envolvido por mimerquitas; (5) microclínio com inclusão de plagioclásio e biotita; (6) microclínio com pertitas em filme; (7) biotita, que representa a principal fase ferromagnesiana do biotita leucogranodiorito a monzogranito e (8) epidoto em associação com biotita. Fotomicrografias sob luz transmitida e polarizadores cruzados. Abreviações: $\mathrm{Bt}=$ biotita; $\mathrm{Ep}=$ epidoto; $\mathrm{Mc}=$ microclínio; $\mathrm{Pl}=$ Plagioclásio $\mathrm{Or}=$ ortoclásio; $\mathrm{Mc}=$ microclínio; $\mathrm{Qz}=$ quartzo.

Figura 38. Aspecto do biotita monzogranito milonitizado: (1) porfiroclastos de feldspato potássico em biotita leucomonzogranito com foliação milonítica anastomosada; (2) e (3) detalhe da foliação milonítica bem desenvolvida e forte orientação da biotita em seus planos; (4) porfiroclasto de microclínio com inclusão de epidoto, envolto por quartzo recristalizado; (5) muscovita em associação com os raros cristais de opaco e biotita; (6) titanita em associação com biotita e muscovita; (7) fotomicrografia em luz transmitida com polarizadores descruzados evidenciando a pequena quantidade de biotita presente na rocha e (8) matriz quartzo-feldspática dessas rochas, com microclínio formando pertitas em filme. Abreviações: $\mathrm{Bt}=$ biotita; Mag = magnetita $; \mathrm{Mc}=$ microclínio; $\mathrm{Ms}=$ muscovita; $\mathrm{Pl}=$ plagioclásio; $\mathrm{Qz}=$ quartzo; Ttn = titanita.

Figura 39. Diagrama TAS (Le Bas et al. 1986) mostrando variação nos conteúdos de sílica e álcalis, das rochas metaultramáficas e nos metabasitos, classificadas como basaltos e andesitos basálticos. Os dados plotados foram recalculados considerando-se base anidra.... 112

Figura 40. Diagrama de Le Maitre (1989) para classificação de rochas vulcânicas ultrabásicas a intermediárias, mostrando a composição das rochas metaultramáficas e metamáficas do Greenstone Belt Sapucaia em relação a seus conteúdos de $\mathrm{SiO}_{2}$ e $\mathrm{Na}_{2} \mathrm{O}+\mathrm{K}_{2} \mathrm{O}$. As rochas metaultramáficas, devido a seu quimismo, poderiam ser classificadas como komatiítos, embora para essa classificação evidências texturais que comprovem a origem vulcânica sejam necessários.

Figura 41. Diagrama catiônico de Jensen (1976) para classificação de rochas máficas e ultramáficas. Nota-se a concentração das rochas metaultramáficas no campo dos komatiítos peridotíticos e dos komatiítos basálticos, onde plotam duas amostras. Entre as rochas metamáficas, nota-se dispersão, com composições variando entre komatítos basálticos, basaltos tholeiíticos de alto $\mathrm{Mg}$ e basalto cálcio-alcalino.

Figura 42. Diagrama ternário $\mathrm{MgO}-\mathrm{CaO}-\mathrm{Al}_{2} \mathrm{O}_{3}$ para classificação de komatí́tos do tipo Barbenton (Al-depleted komatiites) e rochas relacionadas (Viljoen et al., 1982), mostrando semelhança dos clorita-tremolita xistos e clorita-actinolita xistos com a composição dos komatíítos basálticos, próximo à interface com os komatiítos peridotíticos. Amostras de antofilita-Mg cummingtonita xistos e cloritito não plotam em nenhum dos campos composicionais. 114

Figura 43. Diagramas que ilustram a composição dos principais tipos de komatítos (tipos Barbenton, Munro e Gorgona), de acordo com Arndt et al. (2008), e a comparação desses com as rochas do Greenstone Belt Sapucaia. O limite de $18 \% \mathrm{MgO}$ separa basaltos komatiítos de komatiítos e o limite em $30 \% \mathrm{MgO}$ indica o teor máximo provável de líquidos komatiíticos. Rochas com mais de $30 \%$ de $\mathrm{MgO}$ representam cumulatos de olivina. Notar que no diagrama $\mathrm{TiO}_{2}$ vs $\mathrm{MgO}$, o cloritito não foi plotado, devido a seu conteúdo muito mais elevado de $\mathrm{TiO}_{2}$ $(2,76 \%)$. No diagrama $\mathrm{Al}_{2} \mathrm{O}_{3} / \mathrm{TiO}_{2}$ vs $(\mathrm{Gd} / \mathrm{Yb})_{\mathrm{N}}$, as altas razões $(\mathrm{Gd} / \mathrm{Yb})_{\mathrm{N}}$ e baixas de 
$\mathrm{Al}_{2} \mathrm{O}_{3} / \mathrm{TiO}_{2}$, indicam que granada foi mantida no resíduo de fusão e que os magmas foram formados em grandes profundidades no manto. 116

Figura 44. a) Diagrama AFM de Irvine \& Baragar (1971), mostrando para as rochas metaultramáficas tendência komatiítica e tendência tholeiítica para as rochas metabásicas; b) No diagrama de Hastie et al. (2007), os litotipos metaultramáficos possuem tendência tholeiítica, exceto o cloritito e o antofilita-( $\mathrm{Mg})$ cummingtonita xistos, enquanto para os metabasitos, duas amostras evidenciam tendência cálcio-alcalina.

Figura 45. Diagrama de Hughes (1973) mostrando o campo do espectro ígneo e, fora desse campo, rochas alteradas por processos metassomáticos. Ao lado direito, detalhe das rochas metaultramáficas.

118

Figura 46. Diagramas binários mostrando variações dos conteúdos de \# $\mathrm{Mg}$ vs. $\mathrm{CaO}, \mathrm{Na}_{2} \mathrm{O}$, $\mathrm{P}_{2} \mathrm{O}_{5}$ e FeOt nos metabasitos e rochas metaultramáficas do Greenstone Belt Sapucaia......... 120

Figura 47. Diagramas de Harker, mostrando a relação entre conteúdo de $\mathrm{SiO}_{2}$ vs. óxidos de metabasitos e rochas metaultramáficas do Greenstone Belt Sapucaia e sua comparação com os campos dos basaltos tholeiíticos e komatiítos dos greenstone belts do Domínio Rio Maria, de acordo com Souza et al. (2001).

Figura 48. Diagramas de \#Mg vs. elementos traços para as rochas metabásicas e metaultramáficas do greenstone belt Sapucaia.

Figura 49. Diagramas de Zr vs. elementos maiores (óxidos em \%) para as rochas metabásicas e metaultramáficas do greenstone belt Sapucaia. 123

Figura 50. Diagramas de $\mathrm{Zr} v s$. elementos traços (ppm) para as rochas metabásicas e metaultramáficas do greenstone belt Sapucaia. 124

Figura 51. Distribuição de elementos terras raras normalizados em relação ao condrito (Boyton 1984) das rochas do greenstone belt Sapucaia. 126

Figura 52. Padrões de distribuição de elementos traços incompatíveis normalizados em relação ao manto primitivo para as rochas metaultramáficas e máficas do greenstone belt Sapucaia, segundo Sun \& McDonough (1989).

Figura 53. Diagramas binários de $\mathrm{MgO}$ vs. $\left(\mathrm{La} / \mathrm{Sm}_{\mathrm{N}}\right), \mathrm{Nb} / \mathrm{Th}, \mathrm{Zr} / \mathrm{Y}$ e La/Nb para metabasitos e rochas metaultramáficas do Greenstone Belt Sapucaia.. 128

Figura 54. Diagramas para discriminação de ambiente geotectônico de rochas ultrabásicas e básicas, proposto por Agrawal et al. (2008), baseado nas razões log-transformadas $\ln (\mathrm{La} / \mathrm{Th})$, $\ln (\mathrm{Sm} / \mathrm{Th}), \ln (\mathrm{Yb} / \mathrm{Th})$ e $\ln (\mathrm{Nb} / \mathrm{Th})$.

Figura 55. Ilustração apresentando a geometria básica do diagrama da isocon. A isocon corresponde a $\Delta \mathrm{Ci}=0$ e é designada nesse exemplo pela equação $\mathrm{CA}=0.8 \mathrm{Co}$. Todos os componentes para os quais $\Delta \mathrm{Ci}$ é constante são plotados numa linha paralela à isocon, como $\mathrm{BD}$. Todos os componentes para os quais houve ganho ou perda de massa constante em relação à Co são plotados numa linha que passa pela origem, como AD ou AH (Grant, 1986).

Figura 56. Diagramas Isocon (Grant, 1986) mostrando balanço de massa entre as amostras MCS16 (clorita-tremolita xisto) e MCS36 (clorita-actinolita xisto).. 132

Figura 57. Diagramas Isocon (Grant, 1986) mostrando balanço de massa entre as amostras amostras MCS16 (clorita-tremolita xisto) e MCLS18b (cloritito). 134

Figura 58. Diagramas geoquímicos mostrando a distribuição dos granitoides: (a) diagrama Ab-An-Or normativo (O’Connor 1965 com campos de Barker 1976); (b) diagrama K-Na-Ca 
com tendências para as rochas cálcio-alcalina (CA) com o campo dos Trondhjemitos (Martin 1994)

Figura 59. Diagramas geoquímicos mostrando a distribuição dos gnaisses e granitos: (a) diagrama $\mathrm{SiO}_{2}$ vs $\mathrm{FeO} /(\mathrm{FeO}+\mathrm{MgO})$ de Frost et al. (2001) para granitos ferrosos ou magnesianos; (B) diagrama ASI vs. A/NK de Frost et al. (2001); (c) diagrama AFM (A = $\mathrm{Na}_{2} \mathrm{O}+\mathrm{K}_{2} \mathrm{O} ; \mathrm{F}=\mathrm{FeO}+0,9 * \mathrm{Fe}_{2} \mathrm{O}_{3} ; \mathrm{M}=\mathrm{MgO}$ ) de Irvine \& Baragar (1971); (d) Digrama $\mathrm{SiO}_{2}$ vs. $\mathrm{Na}_{2} \mathrm{O}+\mathrm{K}_{2} \mathrm{O}+\mathrm{CaO}$; (e) diagrama de discriminação dos elementos maiores para leucogranitos (Sylvester 1989). 138

Figura 60. Diagramas de Whalen et al. (1987) para distinção entre granitos dos tipos A e I \& S, mostrando a classificação dos gnaisses e granitos da área de Água Azul do Norte. 139

Figura 61: Diagramas de Harker mostrando as variações composicionais dos granitoides estudados. 141

Figura 62. Diagramas de Harker para elementos traços das rochas granitoides. 142

Figura 63: Diagramas dos elementos traços das unidades da área de Água Azul do Norte: (a) diagrama $\mathrm{Zr}$ vs $\mathrm{Rb} / \mathrm{Sr}$, (b) diagrama $\mathrm{La} / \mathrm{Yb}$ vs $\mathrm{Sr} / \mathrm{Y}$.

Figura 64: Padrões de ETR normalizado pelo condritos de Boyton (1984) para os gnaisses e rochas graníticas. 144

Figura 65. Diagrama multielementar normalizado em relação ao condritos de Sun et al. (1980), comparando as amostras de granitoides com a média da composição dos TTG e adakitos de alto conteúdo de sílica (HSA) de Martin et al. (2005). 144

Figura 66. Diagrama de Martin et al. (1999) para a distinção entre TTG, adakitos e rochas de arcos de ilha, mostrando a semelhança dos biotita gnaisses com TTG. 145

Figura 67. Diagramas discriminantes de ambiente tectônico para rochas graníticas de Pearce et al. (1984). 146

Figura 68. Diagrama de $\log (\mathrm{Sr} / \mathrm{Y})$ vs. $\log (\mathrm{La} / \mathrm{Yb})_{\mathrm{N}}$ proposto por Condie e Kröner (2013) para mostrar a distribuição de rochas ígneas félsicas, incluindo vulcânicas, hipoabissais e plutônicas, de diferentes ambientes tectônicos e a comparação entre amostras de gnaisses e granitos da região de Água Azul do norte, Província Carajás, com rochas de arco continental, oceânico, LIPS e rochas félsicas de sequências ofiolíticas. LIP = Large Igneous Province; WI e EI = composição média das rochas ígneas félsicas da Irlanda Ocidental e Oriental, respectivamente (Draut et al. 2002; 2009); EPRB e WPRB = Batólito de Peninsular Range, Califórnia (Lee et al., 2007); Izu = Arco Izu-Bonin, Complexo Granítico Izu (Saito et al. 2007); Whundo = Arco Whundu, Pilbara, Austrália (Smithies et al., 2005). Exceto para as amostras do Complexo Xingu, cada ponto no gráfico refere-se ao valor médio de cada localidade. Análises compliladas por Condie e Kröner (2013). Composições médias da crosta continental são de Rudnick \& Gao (2003). 


\section{LISTA DE TABELAS}

Tabela 1 - Síntese dos dados geocronológicos das unidades do Domínio Rio Maria. 45

Tabela 2: Síntese dos dados geocronológicos das unidades do Domínio Carajás 50

Tabela 3. Composições químicas médias de rochas metaultramáficas e metamáficas do greenstone belt Sapucaia, região de Carajás.

Tabela 4. Cálculos de balanço de massa entre as amostras MCS16 (clorita-tremolita xisto) e MCL36 (clorita-actinolita xisto).

Tabela 5. Cálculos de balanço de massa entre as amostras MCS16 (clorita-tremolita xisto) e MCLS18b (cloritito). 134

Tabela 6. Composições químicas representativas dos granitoides da área de estudo. 137 


\section{SUMÁRIO}

AGRADECIMENTOS

RESUMO

ABSTRACT

LISTA DE FIGURAS

LISTA DE TABELAS

1. INTRODUÇÃO

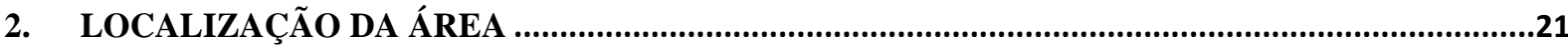

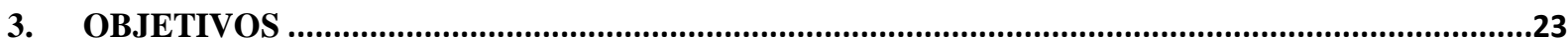

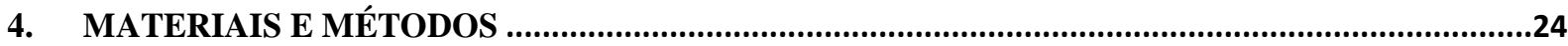

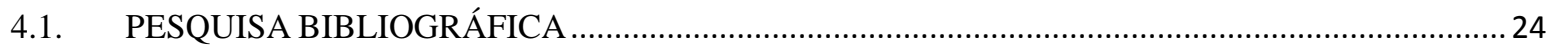

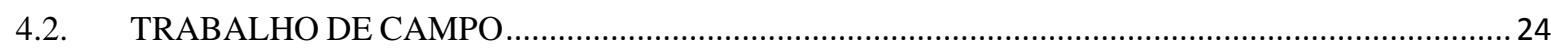

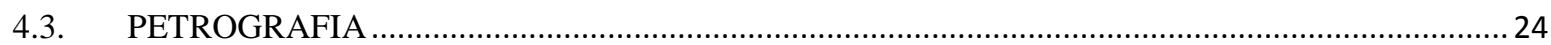

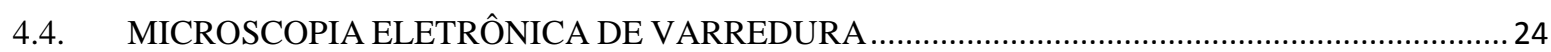

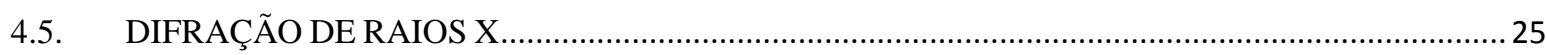

4.6. PREPARAÇÃO DAS AMOSTRAS E ANÁLISES QUÍMICAS ……………………………….....25

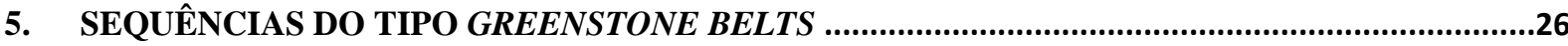

5.1. DISTRIBUIÇÃO ESPACIAL, TEMPORAL E AMBIENTE GEOTECTÔNICO................................ 26

5.2. ESTRATIGRAFIA DE SEQUÊNCIAS DO TIPO GREENSTONE BELT ……............................... 31

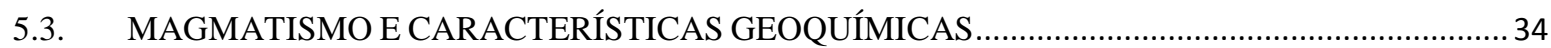

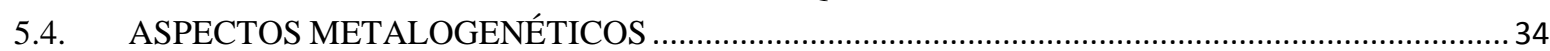

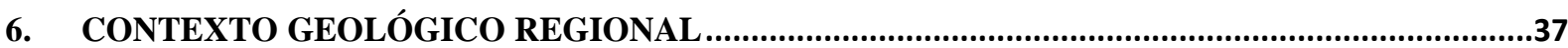

7. O GREENSTONE BELT SAPUCAIA NA REGIÃO DE ÁGUA AZUL DO NORTE, PROVÍNCIA

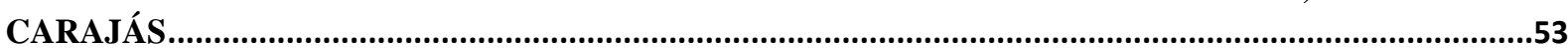

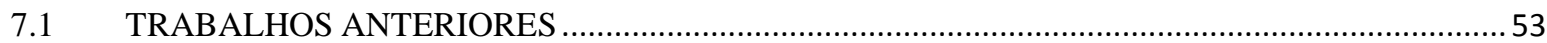

7.2 CONTEXTO GEOLÓGICO DA ÁREA DE ÁGUA AZUL DO NORTE............................................ 55

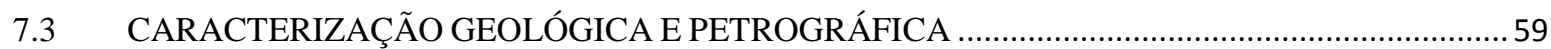

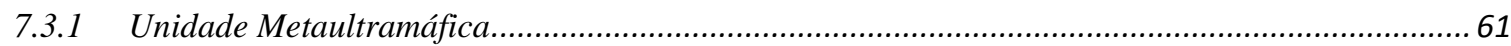

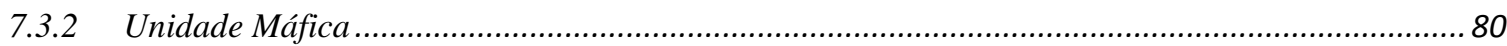

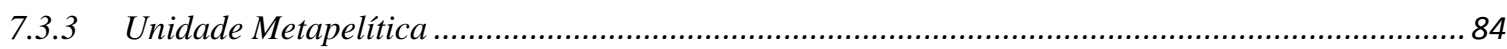

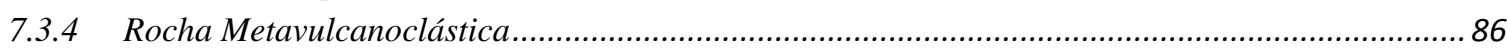

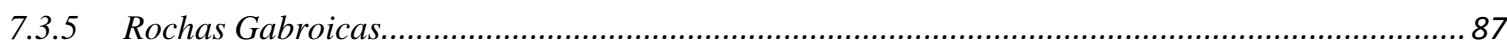

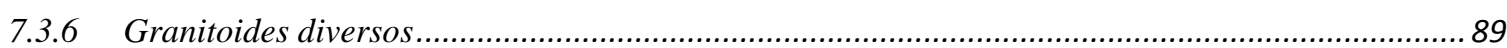

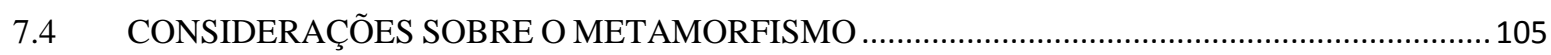

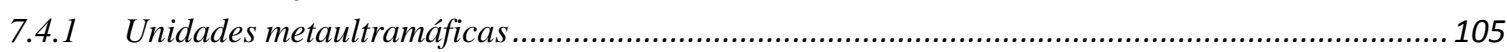

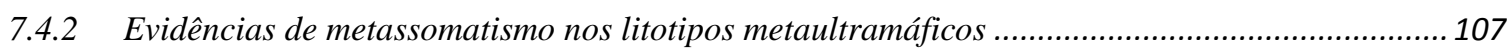

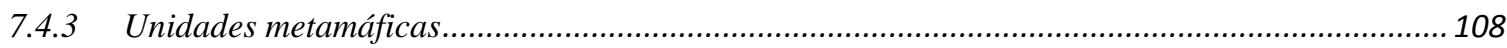

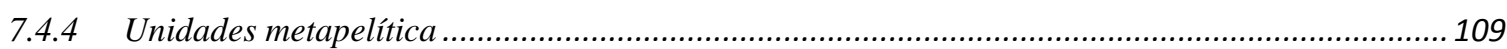

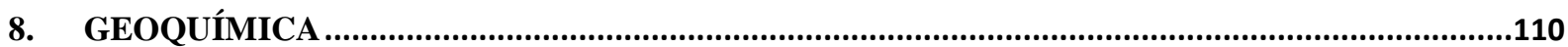

8.1 GEOQUÍMICA DAS ROCHAS METAULTRAMÁFICAS E METAMÁFICAS ….......................... 110

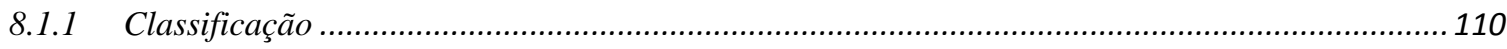

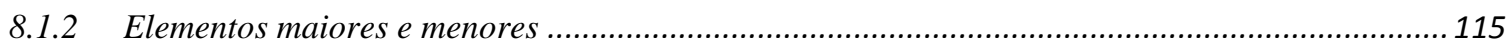

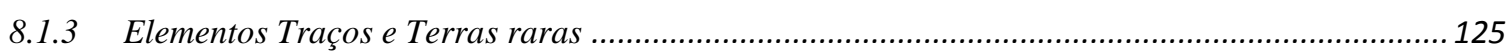


8.1.4 Ambiente geotectônico de formação .......................................................................................128

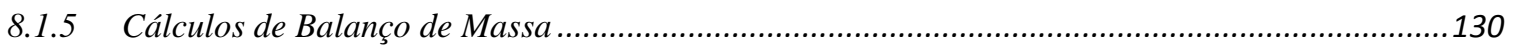

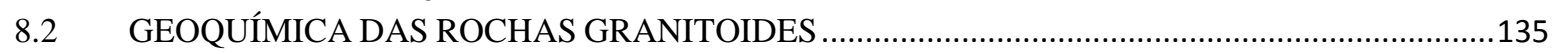

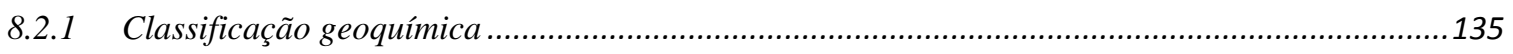

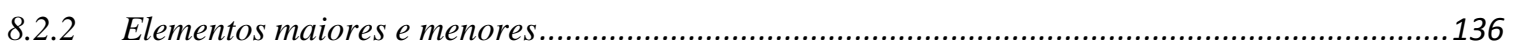

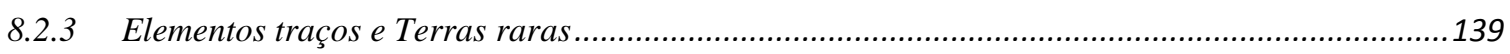

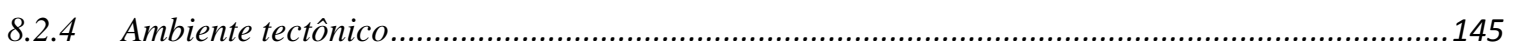

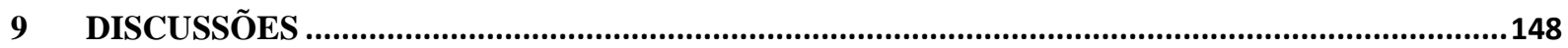

9.1 O GREENSTONE BELT SAPUCAIA: CARACTERIZAÇÃO DOS LITOTIPOS ..........................148

9.2 NATUREZA DO MAGMATISMO ULTRAMÁFICO …...........................................................150

9.3 COMPARAÇÕES DO GRUPO SAPUCAIA COM OS DEMAIS GREENSTONE BELTS DA

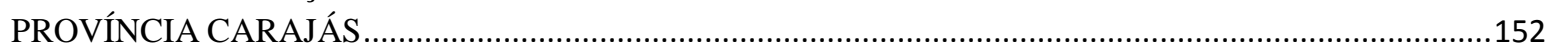

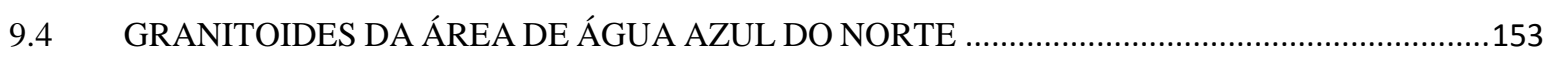

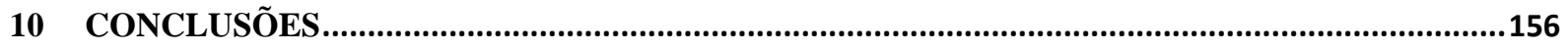

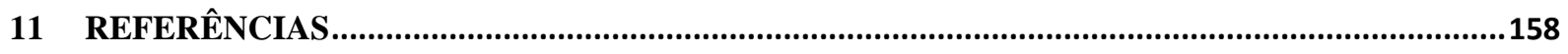

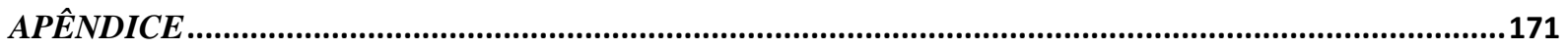

Apêndice 1. Gráfico de difratometria de raios X da amostra MCLS 17 ..............................................172

Apêndice 2. Gráfico de difratometria de raios X da amostra MSC 36 ................................................173

Apêndice 4. Gráfico de difratometria de raios X da amostra MCS 11 ..................................................175

Apêndice 5. Gráfico de difratometria de raios X da amostra MCS 34 ...................................................176

Apêndice 6. Gráfico de difratometria de raios X da amostra MCS 35 ..................................................177

Apêndice 8. Gráfico de difratometria de raios X da amostra MCLS $18 b$..............................................179

Apêndice 9. Gráfico de difratometria de raios $X$ da amostra MCLS $18 d$...............................................180

Apêndice 10. Tabela dos dados geoquímicos analisados. ................................................................... 181 


\section{INTRODUÇÃO}

A Província Carajás (Santos et al. 2000, Santos 2003) compreende o núcleo crustal mais antigo do Cráton Amazônico, formado e estabilizado tectonicamente no Arqueano (Tassinari \& Macambira 1999, 2004). Essa província também destaca-se por representar uma das mais importantes províncias minerais do planeta, na qual são conhecidos depósitos gigantes de minério de ferro de alto teor, de cobre-ouro considerados de classe mundial, de cromo e níquel-EGP associados a intrusões máfica-ultramáficas acamadadas, de tungstênio associado a granitos anorogênicos, depósitos manganesíferos sedimentares e depósitos lateríticos de ouro, níquel e bauxita. Adicionalmente, Carajás também hospeda um dos raros exemplos mundiais de depósito de ouro-EGP associado a rochas metassedimentares, representado por Serra Pelada, que se tornou famoso na década de 1980 devido à intensa atividade garimpeira (Dardenne \& Schobbenhaus 2001; Villas \& Santos 2001; Ferreira Filho et al. 2007; Monteiro et al. 2008).

A Província Carajás é subdividida em dois domínios tectônicos, Carajás, ao norte, e Rio Maria, ao sul (Santos 2003, Vasquez et al. 2008a), limitados por uma descontinuidade regional de direção aproximada E-W. Esses dois domínios apresentam significativas diferenças em sua evolução geológica, reconhecidas a partir das associações litológicas presentes nos dois blocos. No Domínio Rio Maria, estabilizado tectonicamente em ca. 2,86 Ga há predominância de faixas de greenstone belts strictu sensu e magmatismo mesoarqueano tonalítico-trondjemítico-granodiorítico (TTG), sanukitóide e granitos anorogênicos (Oliveira et al. 2009a, Oliveira et al. 2010, Almeida et al. 2010, 2011). No Domínio Carajás, unidades metaultramáficas são raras nas sequências metavulcanossedimentares. Adicionalmente, um importante evento de granitogênese (ca. 2,76 - 2,74 Ga; Huhn et al. 1999b, Avelar et al. 1999, Feio et al. 2013) e desenvolvimento de zonas de cisalhamento durante o Neoarqueano são restritos a esse domínio. Magmatismo granítico anorogênico paleoproterozóico (ca. 1,88 Ga; Machado et al. 1991, Dall'Agnoll et al. 2006) é amplamente reconhecido nos dois domínios, assim como coberturas sedimentares arqueanas a paleoproterozóicas.

Próximo ao limite entre esses dois domínios, na região localizada entre os municípios de Xinguara e Água Azul do Norte, são reconhecidas ocorrências de rochas pertencentes a uma sequência metavulcanossedimentar atribuída ao Grupo Sapucaia (Araújo \& Maia, 1991), que aflora na forma de corpos alongados dispostos em trend E-W. Estudos sistemáticos que permitam a caracterização geológica desses litotipos e sua correlação com as sequências do tipo greenstone belt conhecidas no Domínio Rio Maria ainda não são reportados na literatura.

Na região de Água Azul do Norte, poucos estudos foram realizados com ênfase nos corpos da sequência greenstone belt, necessitando-se, portanto, de estudos detalhados para 
melhor individualização das variedades litológicas e sua distribuição espacial, bem como redefinição de seus limites e suas relações de contato com as demais unidades, caracterização petrográfica das diferentes variedades e caracterização dos processos deformacionais e metamórficos que afetaram as rochas deste grupo.

Tendo em vista a carência de estudos, a variedade e importância destas rochas que ocorrem na região de Água Azul do Norte, os estudos realizados nesse projeto de mestrado visaram à caracterização petrográfica e geoquímica dessas rochas, bem como a compreensão de seus aspectos metalogenéticos. 


\section{LOCALIZAÇÃO DA ÁREA}

A área de estudo localiza-se na porção leste da sede do município de Água Azul do Norte, no sudeste do Estado do Pará (Fig. 01). A partir de Belém o percurso de $853 \mathrm{~km}$ é realizado pela rodovia PA 150 até o município de Xinguara e depois pela rodovia PA 279 no sentido de Água Azul do Norte.

A partir de Marabá, cidade com voos regulares mais próxima, o percurso de $317 \mathrm{~km}$ também pode ser feito pela rodovia PA 150 até o município de Xinguara e depois pela PA 279 sentido Água Azul do Norte ou, alternativamente, é possível seguir pela rodovia PA 150 até o município de Eldorado dos Carajás e depois pela PA 275 em direção à cidade de Canaã dos Carajás, a partir de onde segue-se por estradas vicinais. Em linha reta, a distância do centro da cidade de Água Azul do Norte até a área de estudo, é de aproximadamente $30 \mathrm{~km}$. 
A)

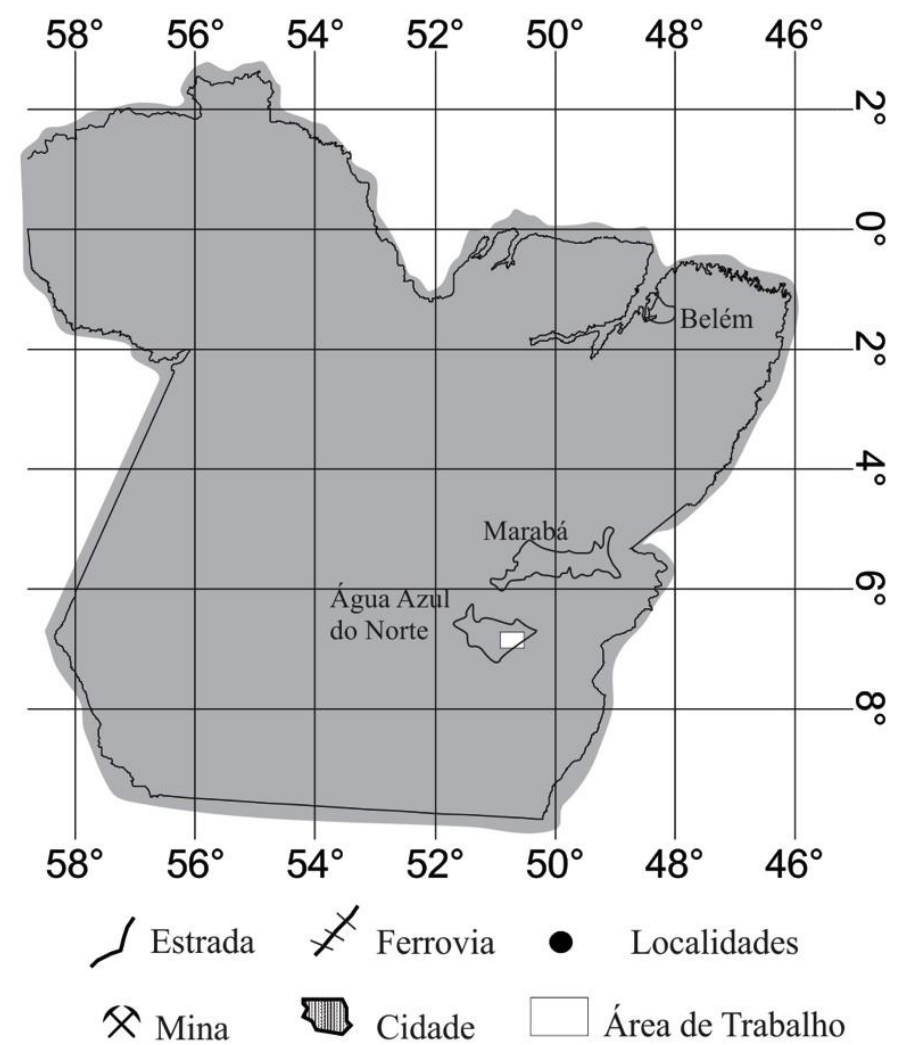

B)

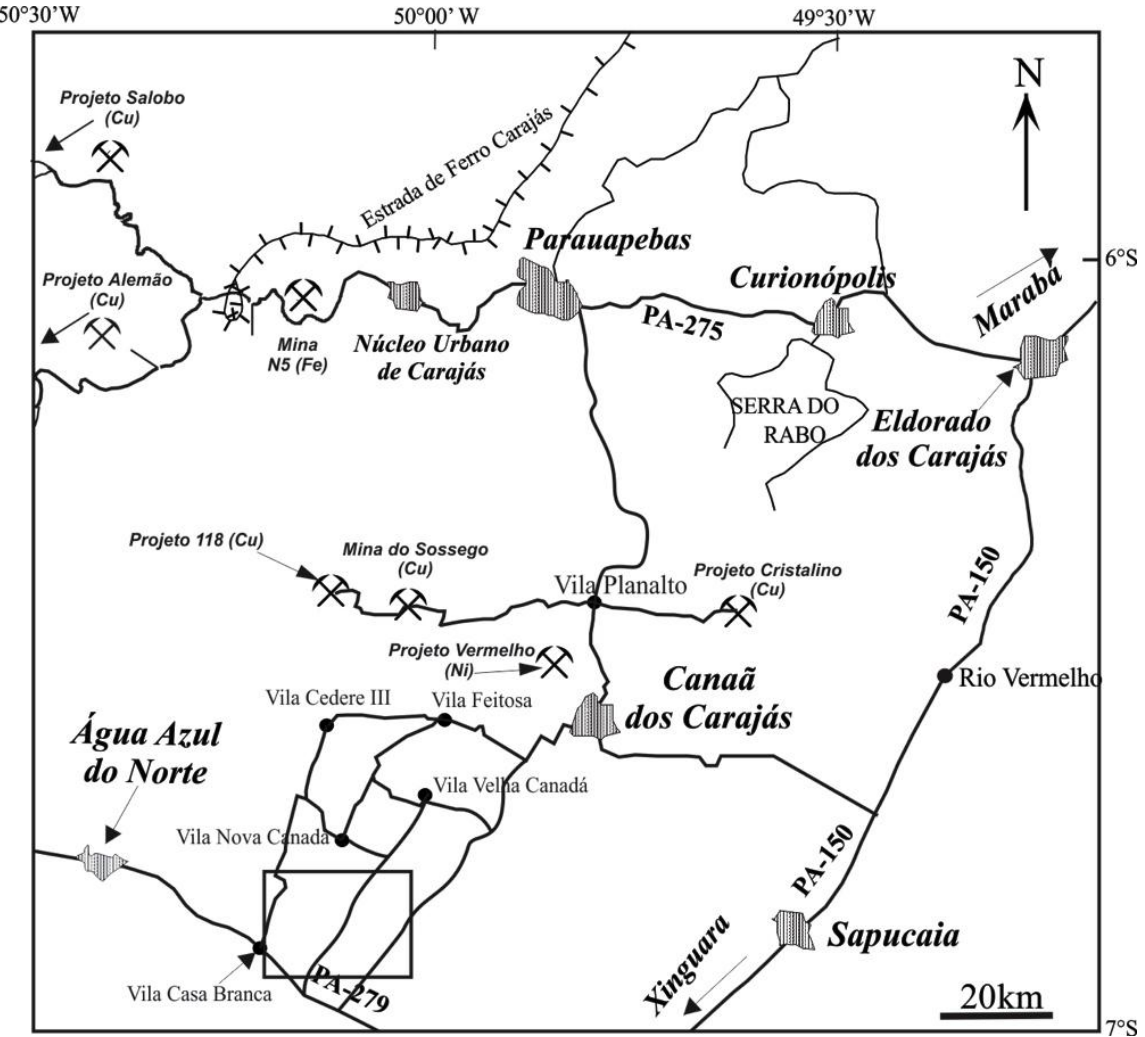

Figura 1. Mapa de localização da área de estudo: A) localização da área no contexto do Estado do Pará; e B) principais vias de acesso no contexto regional (modificado de Leite 2004). 


\section{OBJETIVOS}

Este projeto propõe a caracterização geológica, petrográfica e geoquímica da associação de rochas máficas-ultramáficas atribuídas ao Grupo Sapucaia e a identificação do seu ambiente de formação, visando reconstituir o significado tectônico e metalogenético dessa unidade e suas relações com a evolução da Província Carajás no Mesoarqueano. Associado ao objetivo principal pretende-se alcançar os seguintes objetivos específicos:

$\checkmark \quad$ Caracterização petrográfica e geoquímica dos litotipos do Grupo Sapucaia;

$\checkmark \quad$ Caracterização das relações de contato com as demais unidades;

$\checkmark \quad$ Comparação da associação de rochas do Grupo Sapucaia com as unidades litológicas características de greenstone belts;

$\checkmark \quad$ Identificação das condições metamórficas e dos processos deformacionais que afetaram a unidade;

Confecção do mapa geológico em ambiente SIG. 


\section{MATERIAIS E MÉTODOS}

\subsection{PESQUISA BIBLIOGRÁFICA}

A pesquisa bibliográfica consistiu no levantamento bibliográfico referente ao contexto geológico da Província Carajás, artigos e livros sobre temas relacionados à geologia de terrenos arqueanos, com ênfase à gênese e estratigrafia das sequências greenstone belts, aspectos petrográficos de rochas metamórficas, tipos de texturas, microtectônica e processos metamórficos. Para acesso a esses dados foram utilizados o acervo da biblioteca do IG-USP e os sistemas de buscas de dados do Sistema Integrado de Bibliotecas da Universidade de São Paulo (SiBi/USP) e as bases de dados DEDALUS, SCIELO, ERL, ProBe, Web of Science e aquelas disponíveis a partir do portal CAPES.

\subsection{TRABALHO DE CAMPO}

Os trabalhos de campo foram precedidos por análise analógica e digital de imagens de satélite (Landsat 7 e TM), mosaicos de radar (SRTM) e de cartas aero-radiométricas e aeromagnetométricas. A etapa de campo foi realizada entre os dias 08 e 18 de julho de 2012, visando à realização de perfis geológicos em escala 1:60.000, acompanhados de coleta de amostras em 45 pontos (Fig. 01) para estudos petrográficos e litoquímicos. Os afloramentos foram descritos em seus aspectos litológicos e estruturais, enfatizando-se as relações de contato.

\subsection{PETROGRAFIA}

Os estudos petrográficos em luz transmitida e refletida foram realizados no Instituto de Geociências da Universidade de São Paulo - USP em 61 lâminas delgadas e delgadas-polidas, visando à identificação dos litotipos (Kerr 1959; Deer et al. 1992), suas paragênesess minerais, análise das texturas e estruturas microtectônicas, relações de blastese mineral e foliações metamórficas, bem como possíveis evidências de metassomatismo e alteração hidrotermal. Estudos microtectônicos foram realizados visando à identificação das principais feições deformacionais e relações de blastese e desenvolvimento de foliações metamórficas.

\subsection{MICROSCOPIA ELETRÔNICA DE VARREDURA}

Estudos de microscopia eletrônica de varredura (MEV) com detectores de elétrons retro-espalhados, secundários e catodoluminescência foram realizados no Instituto de Geociências da UNICAMP com utilização de microscópio eletrônico LEO 430i com varredura digital acoplado à espectrômetro de energia dispersiva (EDS) da Oxford Instruments, que permitiu a realização de análises de química mineral semi quantitativas. Os estudos com uso de MEV visaram também à caracterização detalhada de fases minerais, 
zoneamentos composicionais, cristalizações secundárias, exsoluções, intercrescimentos, assim como o estabelecimento de controles das relações micro-estruturais e texturais dos minerais com suas variações químicas.

Para a obtenção das imagens de elétrons retro-espalhados a energia do feixe foi mantida em $20 \mathrm{kV}$ e a corrente do feixe que atinge a amostra ajustada para valores de $6000 \mathrm{pA}$. A distância de trabalho foi fixada em $19 \mathrm{~mm}$, em virtude da geometria e disposição do detector EDS dentro da câmara, garantindo uma maior eficiência na aquisição de sinais EDS da amostra e, portanto, melhor qualidade de análise.

\subsection{DIFRAÇÃO DE RAIOS X}

A caracterização mineralógica também foi realizada com o auxílio de análises de difração de raios X com uso de difratômetro SIEMENS, modelo D5000, do Laboratório de Difração de Raios X do Departamento de Mineralogia e Geotectônica do Instituto de Geociências da USP. As análises foram realizadas utilizando-se ânodo de CuK $\alpha$ com a tensão de $40 \mathrm{kv}$ e corrente de $40 \mu \mathrm{A}$. Os intervalos de $2 \Theta$ medidos, variaram de 3-65 2Ө, com passo de 0,05 2Ө/s/passo. As interpretações foram feitas com uso do software Diffacat Plus, utilizando-se o banco de dados Powder Difraction, set1-45, de 1995 (http://www.icdd.com).

\subsection{PREPARAÇÃO DAS AMOSTRAS E ANÁLISES QUÍMICAS}

As amostras foram cominuídas em prensa hidráulica a menos de $0,5 \mathrm{~cm}$ de diâmetro e moídas em moinho de carbeto de tungstênio durante 3 a 6 minutos, dependendo da amostra, até aproximadamente $90 \%$ passante em peneira de 0,075 mm (200 mesh). Após a moagem, foi realizada homogeneização e quarteamento, separando-se uma alíquota para arquivo e outra para as análises. As análises foram realizadas no Laboratório ACME Analytical Laboratories Ltda., sendo utilizados os pacotes analíticos 4A e 4B. Os métodos empregados e os limites de detecção podem ser encontrados no site do laboratório (www.acmelab.com).

Os elementos maiores e menores foram analisados em Espectrômetro de Emissão com Plasma Indutivamente Acoplado (Inductively Coupled Plasma Emission Spectrometry, ICPES), enquanto elementos traços e terras raras foram quantificados em Espectrômetro de Massa com Plasma Indutivamente Acoplado (Inductively Coupled Plasma Mass Spectrometry, ICPMS), após fusão com metaborato/tetraborato de lítio e digestão com ácido nítrico. Os voláteis foram determinados na perda ao fogo por sinterização a $1000^{\circ} \mathrm{C}$ e o total de carbono e enxofre pela combustão em forno de indução com alta frequência (técnica LECO). Os dados litoquímicos foram tratados com uso do software livre GCDKit for Windows 3.0 (Janousek et al. 2011). 


\section{SEQUÊNCIAS DO TIPO GREENSTONE BELTS}

As sequências metavulcanossedimentares do tipo "greenstone belts" (cinturões de rochas verdes) compreendem rochas máficas-ultramáficas associadas a rochas sedimentares metamorfisadas geralmente em baixo grau, predominantemente na fácies xisto-verde (Neves 2001) e representam importantes áreas de pesquisa devido à sua importância petrogenética relativa à evolução precambriana da Terra e metalogenética. Ocupam segmentos estreitos nos crátons, geralmente circundados por rochas graníticas formando os típicos terrenos granitogreenstone arqueanos.

Terrenos arqueanos são inquestionavelmente regiões complexas e nem sempre possuem exposição adequada ou preservada a ponto de permitir uma avaliação da natureza de todos os seus litotipos, suas relações estratigráficas e estruturais e reconstituição do seu ambiente de formação, resultando em uma variedade de modelos reconstrutivos. Há praticamente duas décadas pensava-se que os greenstone belts representavam rochas restritas ao Arqueano. Atualmente, essas sequências, predominantemente arqueanas, vêm sendo reconhecidas em terrenos mais novos, indicando que os greenstone belts se formaram ao longo do tempo geológico, porém com ocorrências apenas pontuais no Paleoproterozóico e mais raras ainda no Fanerozoico, registrando diversidades litológicas, estratigráficas e principalmente características distintas relativas ao ambiente de colocação tectônica (Condi 1989).

Diversos fatores devem ser considerados na reconstrução da história geológica dos terrenos granito-greenstone, destacando-se as características geológicas e geoquímicas que fornecem um conjunto importante de informações para a elaboração de modelos que explicam a sua origem e evolução. Os modelos de evolução crustal dependem do desenvolvimento termal do planeta e os greenstone belts, formados em um período da história da Terra com alto gradiente térmico, representam importantes registros dessa evolução. Porém, qualquer tentativa de proporcionar uma síntese completa e universalmente aceita para evolução geológica e geotectônica desses ambientes oferece ainda restrições e muitas dificuldades.

\subsection{DISTRIBUIÇÃO ESPACIAL, TEMPORAL E AMBIENTE} GEOTECTÔNICO

Por suas características geológicas e ocorrência em diversos blocos continentais do planeta, os greenstone belts são tratados como unidades individualizadas no âmbito dos diversos tipos de complexos vulcanossedimentares. 
Esses terrenos apresentam largura variando de 20 a $100 \mathrm{~km}$ e comprimento de 100 a $300 \mathrm{~km}$, podendo chegar até $1000 \mathrm{~km}$. Além das dimensões, as formas são variadas, apresentando-se curvelineares, lineares e amebóides. Entretanto, sua distribuição indica que os greenstone belts fazem parte de um largo sistema orogenético (De Wit \& Ashwal 1997).

Sequências do tipo greenstone belts estão distribuídos ao longo da história, em vários crátons de todos os continentes. Exemplos importantes incluem os da América do Norte, como a Província Superior do Canadá (e.g., Polat \& Kerrich 2001; Cousens et al. 2002); da Europa, Central Lapland na Finlândia (e.g., Hanski et al. 2005); Barberton, África do Sul (e.g., Anhaeusser 1971, 1982; Arndt \& Nisbet 1997), na Oceania, Austrália, Kalgoorlie (e.g., Bateman et al. 2001), na América do Sul os do Supergrupo Rio das Velhas (e.g. Schorscher 1994; Vial et al. 2007) e Rio Itapicuru no Bloco Serrinha (e.g. Silva 1983, 1987) do cráton São Francisco, no Brasil; dentre outros.

A formação de terrenos granito-greenstone tem decrescido desde a formação inicial da crosta no Arqueano, já que são resultantes de processos que deram origem à mesma. A origem de greenstone belts mais antigos que 3000 Ma é interpretada como relacionada à tectônica vertical, que teria resultado em fendas relacionadas a placas em rifts continentais, complexos acrescionários e centros de expansão oceânica (Lowe 1994). Para Shackleton (1995), são caracterizados inicialmente pela formação das rochas vulcânicas komatiíticas que foram sendo progressivamente substituídas por rochas vulcânicas basálticas a félsicas no decorrer do tempo geológico e a sedimentação que acompanha o processo evoluiu de predominantemente química para clástica.

Foi sugerido que greenstone belts associados à diferentes eventos podem coexistir na mesma região, como descrito por Wilson $(1979,1981)$ no cráton Rhodesin, no qual sequências metavulcanossedimentares podem ser divididas em Greenstone Superior (2700 Ma) e Greenstone Inferior (idade provável de 3000 Ma). De modo análogo, Glikson (1976) reconheceu sequências greenstone de várias idades em várias partes do mundo, descrevendoas como greenstones primários e secundários, incluindo os cinturões da Índia e oeste da Austrália. Os primários foram definidos como predominantemente compostos por sequências máficas-ultramáficas, de ocorrência generalizada que representariam a crosta oceânica primitiva. Os secundários consistiriam de ciclos vulcânicos bimodais (basalto-andesitoriolito) desenvolvidos em regiões parcialmente cratonizadas.

De acordo com Anhaeusser (1982), os estilos deformacionais de complexos arquenos são únicos e podem ser descritos como resultantes de duas fases principais. A primeira relaciona-se com a configuração geotectônica primária e ainda permanece enigmática, porém seria nessa fase, em um ambiente dominado pelo alto fluxo de calor e pela influência Dissertação de Mestrado - IG-USP - Soraya Damasceno Sousa - 2014 
gravitacional, que seriam gerados os primeiros tonalitos/throndhjemitos por fusão parcial. Na segunda fase, a cratonização incipiente resultaria na formação de greenstone mais jovens como resultado do faturamento crustal e do desenvolvimento de riftes intracontinentais.

Além das diferenças de idades, essas sequências vulcanossedimentares diferem quanto aos seus ambientes geotectônicos, pois nenhuma ocorrência de greenstone belts é idêntica e cada uma se formou seguindo uma vasta gama de padrões sequenciais de desenvolvimento, embora possam ser discernidos em sua evolução processos comuns para a maioria deles, incluindo vulcanismo, plutonismo, sedimentação, metamorfismo e mineralizações associadas (Anhaeusser 1982).

A tectônica dos greenstone belts, em geral, é caracterizada por várias fases, sendo que para Ramsay (1963) e Shackleton (1995), a primeira fase é a de caráter extensional, seguida por compressão e, posteriormente, encurtamento da crosta. Durante o processo de evolução destas rochas, a formação de domos é um elemento importante, pois geralmente estão relacionados a processos de subducção seguida de acresção colisional no final do processo tectônico, indicando o envolvimento de tectônica vertical (De Wit \& Ashwal 1997).

Embora o metamorfismo mais comum nos greenstone belts seja o de fácies xisto verde, os estudos mais recentes têm revelado que alguns dessas sequências foram submetidas a condições de alto grau de metamorfismo. A transição de greenstone belt para terrenos de alto grau metamórfico geralmente ocorre ao longo de falhas reversas intracratônicas ou em margens transpressivas adjacentes a regiões de impacto (De Wit \& Ashwal 1997).

Diversos modelos têm sido utilizados para explicar a evolução dos greenstone belts. No entanto, para se admitir uma proposta evolutiva para essas sequências devem ser correlacionadas características que permitam classificar essas rochas quanto à sua idade. É conhecido que os greenstone belts ocorreram tanto no Arqueano como no Proterozoico, assim, modelos evolutivos são propostos conforme esses intervalos de idade.

A seguir serão apresentados alguns modelos propostos para explicar a origem e evolução desse ambiente.

Hofman (1990) propõe um modelo no qual os greenstone belts se formariam em ambiente de progradação arco-fossa, em que estes seriam os remanescentes dos complexos de acresção da zona fore-arc, e que as rochas vulcânicas seriam formadas em arcos de ilhas alóctones e a proporção sedimentar seria constituída por turbiditos da zona de fossa e por sedimentos pelágicos alóctones. A progradação faz com que partes da zona de acresção sejam diacronicamente intrudidas por granitoides de arco magmático, o que explica a relação cronológica entre as supracrustais e as intrusões graníticas nesses terrenos (Fig. 02). 
$\checkmark \quad$ Para Barth (2007), a evolução destes terrenos teria ocorrido em uma bacia back-arc ou bacias entre protocontinentes, com afundamento por extensão que abre canais para extrusão de rochas máficas e ultramáficas, no processo de sagducção. Quando a crosta se torna espessa, o fundo do oceano constituído de rochas máficas e sedimentos marinhos colapsa, formando os cinturões que são acrescionados para formar a crosta continental arqueana, e a crosta oceânica que resiste à subducção torna-se parte do cráton (Fig. 03).

$\checkmark \quad$ O modelo proposto por Neves (2001) admite a existência de uma crosta siálica que pelo processo de rifteamento resultaria no extravasamento de lavas, originando rochas vulcânicas. As rochas vulcânicas mais densas sofreriam por superposição e gravidade afundamento seguido da ascensão dos domos siálicos (Fig. 04). A evolução dos greenstone belts mais jovens ou com idades contemporâneas aos terrenos de alto grau é comumente associada pela maioria dos autores como resultado da tectônica compressiva. Este modelo é sugerido devido à presença de falhas de empurrão, transcorrências e dobras recumbentes que ocorrem com frequência nas sequências proterozoicas. Logo, a tectônica de acresção evidenciaria a atuação de processos de bordas de placas similares às atuais, onde seriam produzidos vulcanismo e sedimentação em bacias marginais ao mesmo tempo em que a associação TTG seria produzida em arcos magmáticos.

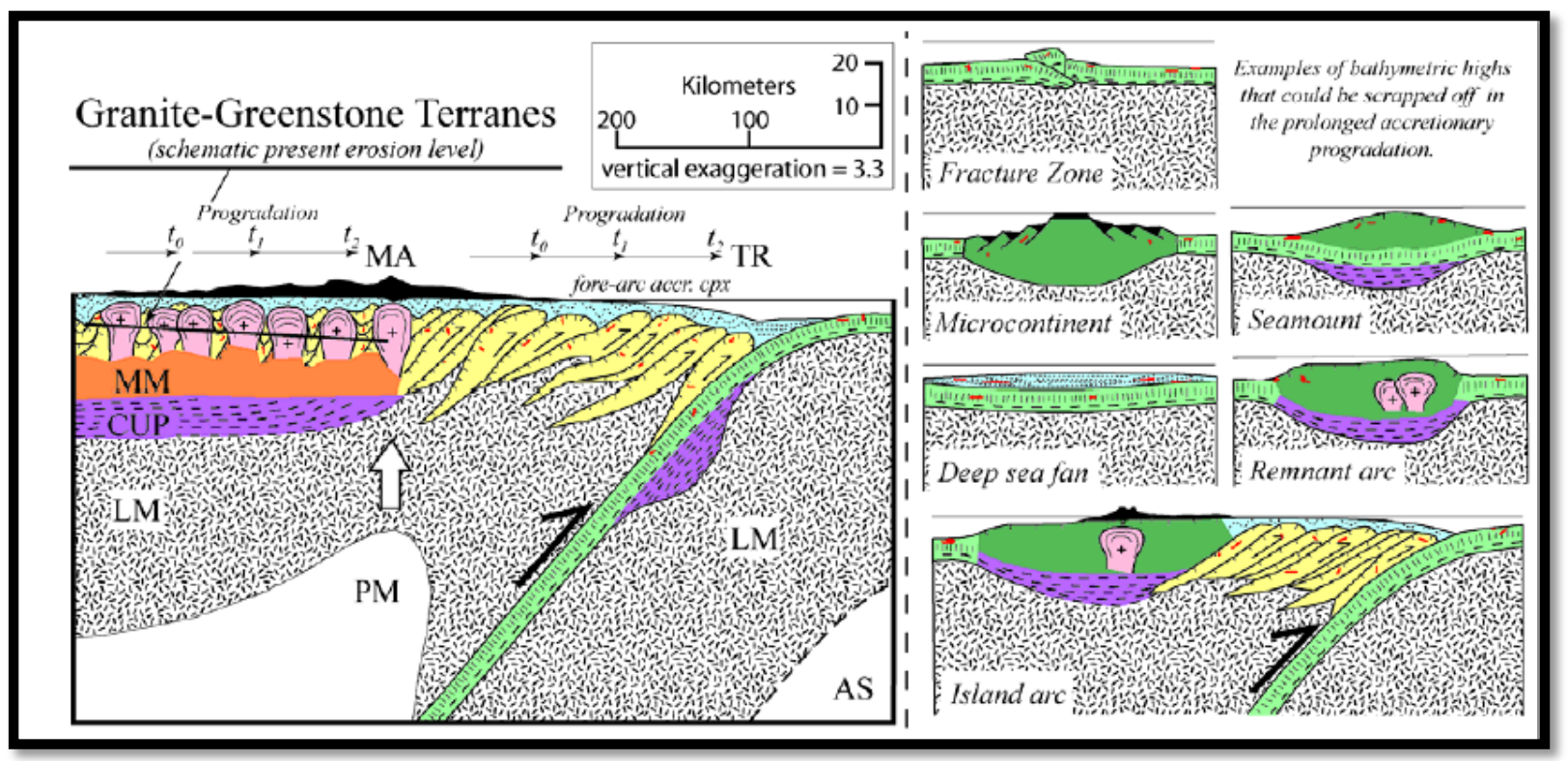

Figura 2. Modelo de geração dos Greenstones belts devido à progradação arco-fossa (Hoffman,1990). 


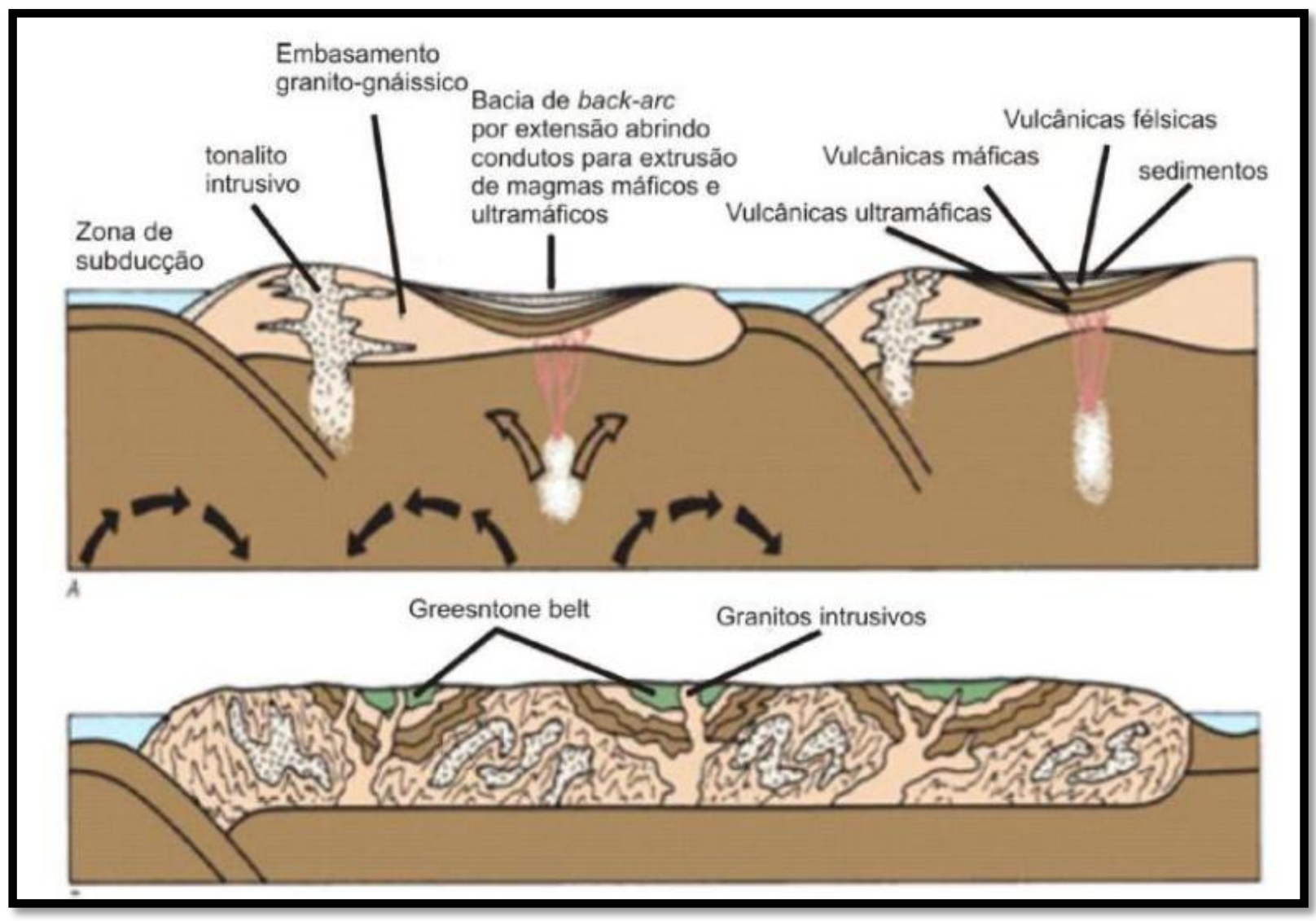

Figura 3. Extrusão de magma ultramáfico por extensão e posterior acrescão ao continente. (Barth 2007).

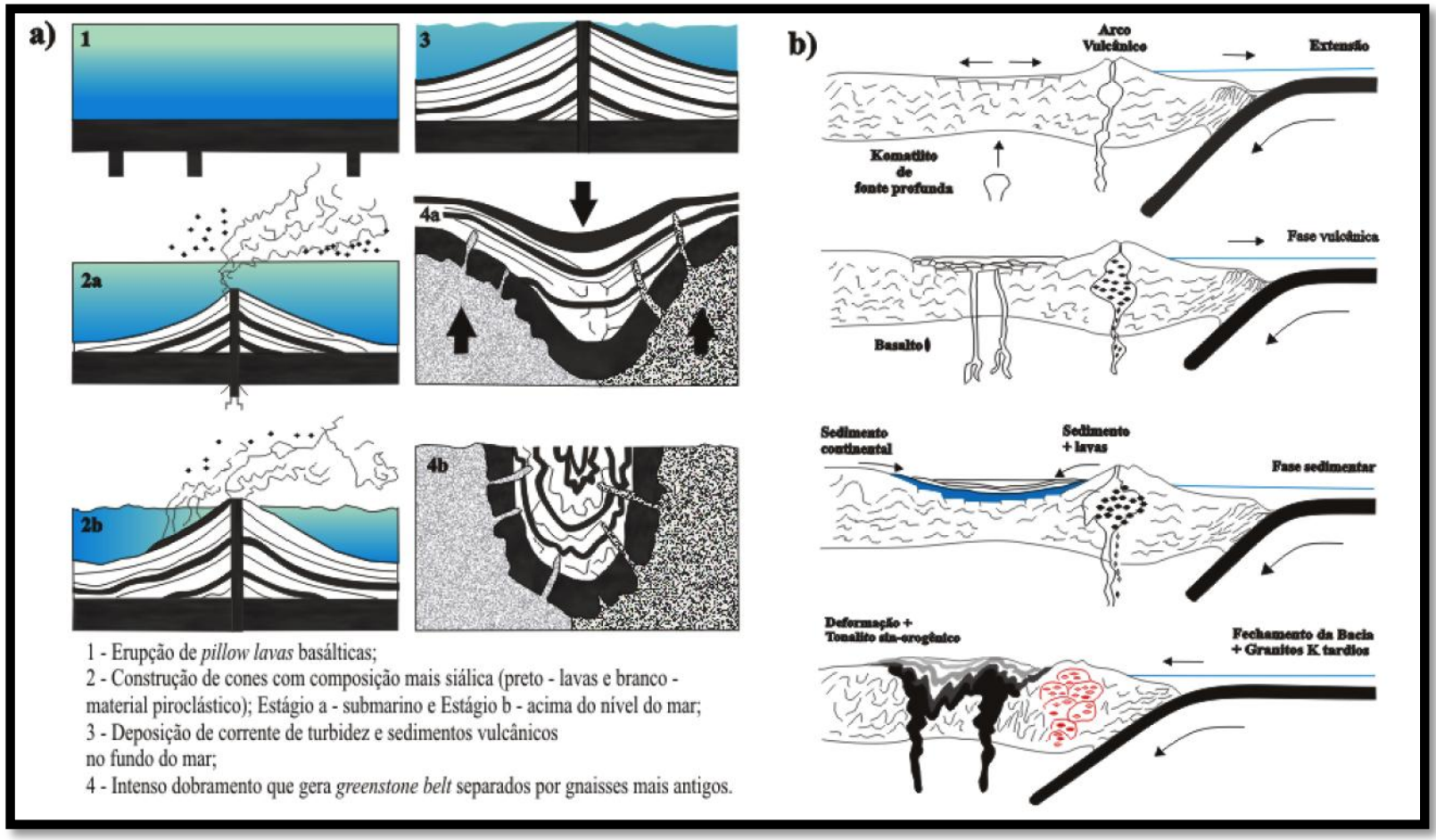

Figura 4. Modelos tectônicos para formação de greenstone belts. a) Modelos de formação de greenstone belts baseado no processo de sagducção; b) Modelo de formação de greenstone belt devido à tectônica de acresção (Neves 2001). 


\subsection{ESTRATIGRAFIA DE SEQUÊNCIAS DO TIPO GREENSTONE BELT}

A evolução estratigráfica das sequências de greenstone belts foi inicialmente relacionada com uma evolução cíclica, que resultaria em todas as sequências em associação de rochas máficas-ultramáficas na base e andesitos e rochas vulcânicas altamente diferenciadas em níveis intermediários sobrepostos por sucessões sedimentares (e.g. Anhaeusser 1971). As unidades basais foram consideradas como representantes da crosta oceânica máfica primitiva, enquanto as sequências superiores mais evoluídas, assim como os granitoides associados, corresponderiam à evolução de arcos de ilhas ensimáticos (Anhaeusser 1993; Glikson 1976). De acordo com Kröner (1982), similaridades geoquímicas aparentes das rochas vulcânicas máficas-ultramáficas e as rochas mais diferenciadas com MORB moderno e complexos de arco intraoceânicos evidenciam modelos evolutivos relacionados à subducção, que foram o principal motivo para especulações de que o atual ciclo de Wilson operou desde o início do Arqueano.

De forma geral, na tentativa de simplificar a estratigrafia dessas sequências, que apresentam heterogeneidade litológica, os greenstone belts geralmente são subdivididos em três sequências (Fig. 05): (1) sequência inferior dominada por derrames de rochas vulcânicas máficas (tholeiíticos pobre em K) e ultramáficas (komatítos), reconhecida em diversos crátons, tais como Kaapvaal, Yilgarn, Zimbabwe, Báltico e Superior; (2) sequência intermediária, na qual prevalecem ciclos de basaltos tholeiíticos e andesitos e dacitos geralmente com afinidades cálcio-alcalinas; (3) sequência superior dominantemente metassedimentar derivada de sedimentos maturos e imaturos. Algumas intercalações vulcânicas e piroclásticas podem ocorrer (Condie 1981, 1994, Ayres \& Thurston 1985, Hofman 1990 e Neves 2001).

Para Anhaeusser (1982), as sequências mais antigas, máficas-ultramáficas, são representados por basaltos com alto conteúdo de magnésio (predominantemente komatiítos, mas, incluem basaltos tholeíiticos) e peridotitos que ocorrem como derrames subaquosos com estrutura almofadada e intrusões de sills diferenciados. A estratificação ciclicamente repetitiva origina associações de dunitos, peridotitos, harzburgitos, orto e clinopiroxenitos, noritos, gabros e anortositos gabroicos. Ainda segundo esse autor, brechas, tufitos e outras unidades sedimentares vulcanoclásticas estariam presentes na maioria dos greenstone belts e teriam predominantemente fragmentos de rochas félsicas. Chert associados a xistos, argilitos, folhelhos, arenitos quartzosos e conglomerados contendo clastos de rochas plutônicas ou metamórficas antigas foram descritos como sedimentos interfluxo no Bloco Yilgarn, no Grupo Bulawayan (cráton Rhodesian) e de muitas formações no Escudo Canadense (Lowe 1980). 


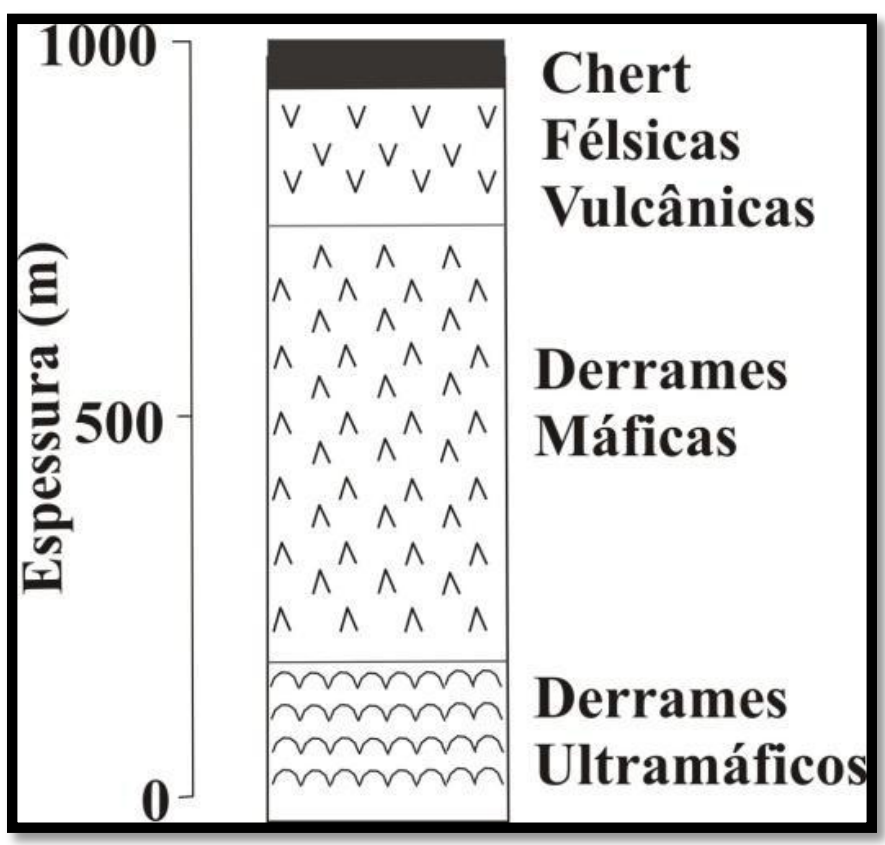

Figura 5. Estratigrafia simplificada de uma sequência greenstone belt, mostrando derrames komatiíticos na base, rochas vulcânicas máficas a félsicas e rochas sedimentares no topo (Condie 1981).

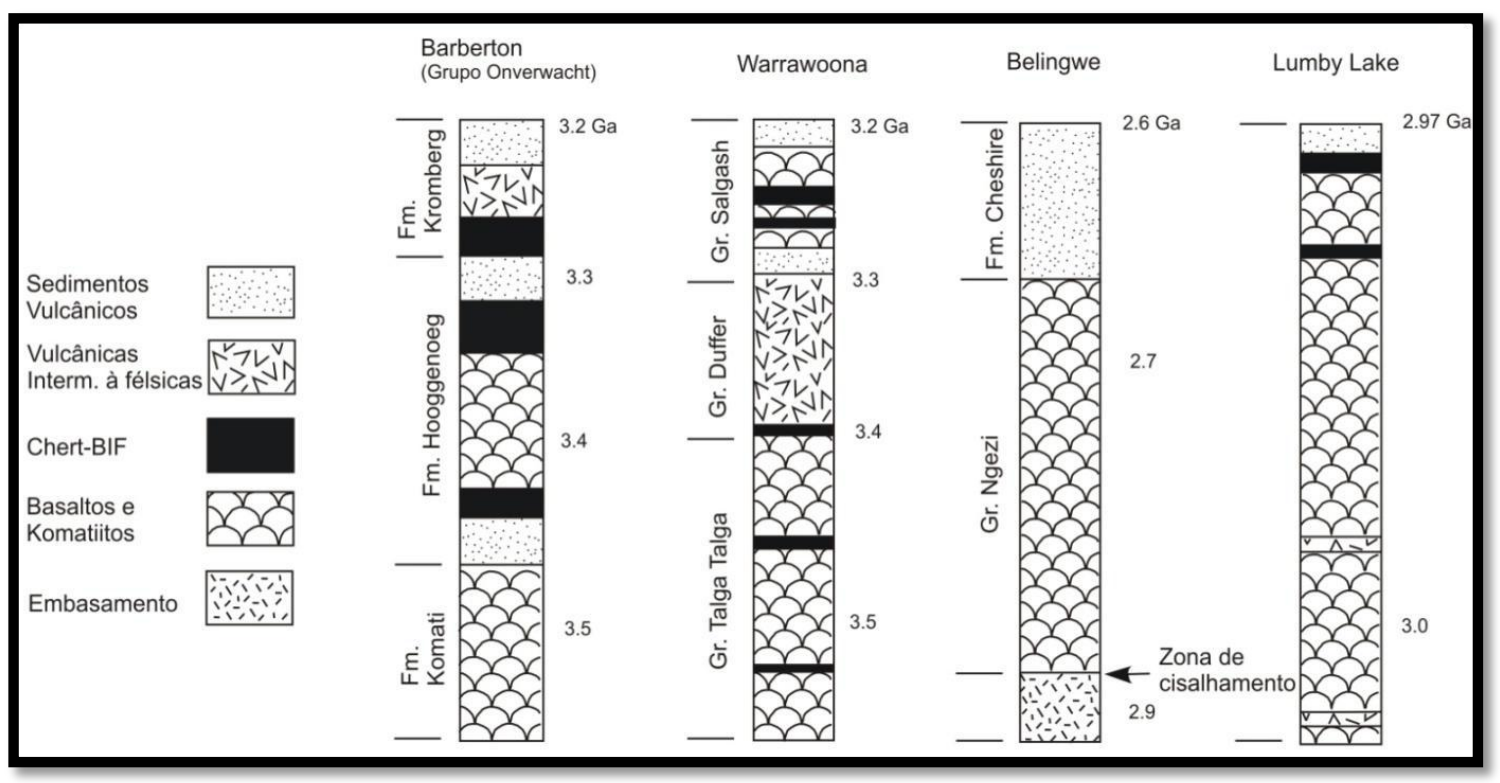

Figura 6. Secção estratigráfica geral para as associações arqueanas (De Wit \& Ashwal 1997).

$\mathrm{O}$ arcabouço litoestratigráfico completo das sequências greenstone belt inclui, da base para o topo, segundo Ayres \& Thurston (1985), Hofman (1990) e Condie (2001): 
1) Magmatismo komatiítico ou basáltico, com geração de rochas vulcânicas e plutônicas subordinadas, ultramáficas e máficas, em ambiente submarino, com estruturas tipo pillow lavas e spinifex, podendo conter sedimentação química;

2) Magmatismo tholeiítico, predominantemente vulcânico máfico a intermediário, raramente félsico, de ambiente submarino, com características geoquímicas híbridas de basalto tipo MORB e basalto tholeiíticos de arco de ilha (Island Arc Tholeiites, IAT);

3) Intercalações de sedimentos químicos e pelíticos - cherts, formações ferríferas bandadas, filitos grafitosos e outros - e sedimentos clásticos de granulometria grossa de derivação vulcânica intermediária a félsica;

4) Magmatismo cálcio-alcalino intermediário a félsico, raramente máfico, com expressão tanto vulcânica quanto plutônica, com características geoquímicas similares às dos vulcanitos cálcio-alcalino de arcos modernos;

5) Magmatismo alcalino tardio, em geral ausente na maioria dos terreno granitogreenstone, vulcânico e plutônico, com características geoquímicas comparáveis a dos vulcanitos de arcos de ilhas modernos;

6) Sedimentos clásticos grossos a finos, de derivação vulcânica intermediária a félsica, associadas a sedimentos químicos;

7) Granitos intrusivos, tanto do tipo I, quanto anatéticos, tipo S;

Com associações típicas com terrenos granito-greenstone, rochas granitoides ocorrem isolando as ocorrências de greenstone belts. Apresentam comumente composição tonalítica e/ou granodiorítica, sendo os trondhjemitos subordinados, compondo os TTG (tonalitosgranodioritos-trondhjemitos). $\mathrm{Na}$ maioria das vezes ocorrem na forma de batólitos, com bandamento composicional e variável grau de deformação. Os granitos potássicos que ocorrem em terrenos arqueanos são considerados mais jovens, abrangendo granitos de composição monzogranítica e granitos do tipo S. Formam corpos menores com contatos intrusivos bruscos e discordantes com os demais litotipos. Esses granitos geralmente não apresentam foliação, tão pouco vestígios de deformação (Cavalcanti 2007).

Segundo Anhaeusser (1982), em algumas regiões, corpos subvulcânicos de quartzofeldspato pórfiros geneticamente ligados com o desenvolvimento de sequências vulcânicas foram reconhecidos em greenstone belts. Estes corpos são principalmente granodioríticos ao invés de trondhjemíticos, refletindo mudanças químicas evolutivas no desenvolvimento de sistemas greenstone belts. 
Embora as sequências metavulcanossedimentares apresentem uniformidade quanto à estratigrafia, muitos possuem feições distintas. As sequências da África do Sul e Austrália mostram maior volume de rochas ultramáficas e máficas, enquanto que aquelas da América do Norte possuem maior volume de rochas cálcio-alcalinas félsicas. Porém, essas variações dependem da diferença de idade entre esses greenstone belts. Estudos comparativos realizados por Lowe (1982) entre os cinturões mais antigos e os mais jovens admitem para tais variações um aumento na abundância e influência de crosta siálica desde o Arqueano assim como aumento na profundidade da água marinha sobre as plataformas vulcânicas (Fig. $06)$.

\subsection{MAGMATISMO E CARACTERÍSTICAS GEOQUÍMICAS}

Magmas komatiíticos geram rochas ultramáficas com alto percentual de magnésio. Os magmas komatiíticos e peridotíticos formam-se à altas temperaturas em condições próximas às anidras $\left(0,2 \% \mathrm{H}_{2} \mathrm{O}\right)$. Para Arndt et al. (2008), komatiítos são rochas que se cristalizaram a partir de magmas que continham mais de $18 \%$ de $\mathrm{MgO}$ e até $44 \% \mathrm{SiO}_{2}$. É complicado, no entanto, distinguir komatítos de basaltos ricos em $\mathrm{MgO}$ que se formaram através da acumulação de olivina a partir de líquidos menos magnesianos ou foram cristalizados a partir de magmas com características geoquímicas diferentes daquelas da maioria dos komatítos. Para distinguir komatiítos de outros tipos de rochas altamente magnesianas, como por exemplo as cumuláticas, é preciso considerar a presença da textura spinifex, que é uma textura caracterizada pela presença de cristais esqueléticos ou dendríticos de olivina ou piroxênio, presente em muitos, mas, não em todos os fluxos komatí́ticos (Nesbitt 1971). Portanto, a definição sobre komatítos deve ser uma "rocha vulcânica ultramáfica com $\mathrm{MgO}>18 \%$ e com textura spinifex ou relacionada com lavas contendo essa textura".

A série komatiítica tem usualmente baixos valores da razão $\mathrm{FeO}(\mathrm{t}) /(\mathrm{FeO}(\mathrm{t})+\mathrm{MgO})(<$ 0,65\%), baixo conteúdo de $\mathrm{TiO}_{2}(<0,9 \%)$ e alto conteúdo de $\mathrm{Ni}(>300$ ppm), $\mathrm{MgO}(18 \%$ $30 \%$ ) e $\mathrm{Cr}$ (> 600 pmm). A cristalização do magma intermediário da série komatíítica resulta em andesito com 54 a $62 \%$ de $\mathrm{SiO}_{2}$, que ocorre subordinado aos basaltos e é ausente em algumas sequências, diferindo dos andesitos mais recentes por possuir alto valor de Fe. As rochas félsicas predominantes são dacito e riolito e possuem entre 62 e $78 \%$ de $\mathrm{SiO}_{2}$ e são formadas geralmente por fluxo de lavas e erupções piroclásticas. São as maiores fontes de sedimentos, sendo assim, representam entre 15 a $20 \%$ das rochas formadoras nos greenstone belts (De Wit \& Ashwal 1997).

\subsection{ASPECTOS METALOGENÉTICOS}

Dissertação de Mestrado - IG-USP - Soraya Damasceno Sousa - 2014 
Devido ao grande número de depósitos minerais já identificados em terrenos greenstone belts, essas sequências representam importantes ambientes para a pesquisa mineral. Uma maior compreensão do contexto geotectônico e estilo de evolução dos terrenos granito-greenstone deve influenciar a abordagem adotada para a avaliação do potencial metalogenético de uma região.

Os tipos de mineralização em terrenos arqueanos são extremamente variados, mas, segundo Anhaeusser (1982) e De Wit \& Ashwal (1997), os tipos de minerais podem ser subdivididos entre aqueles que associam-se com rochas máficas-ultramáficas (principalmente $\mathrm{Au}, \mathrm{Ni}, \mathrm{Cr}$, crisotila, talco e magnesita); sucessões máficas a félsicas (principalmente depósitos de sulfetos maciços contendo importantes mineralizações de $\mathrm{Cu}, \mathrm{Zn}, \mathrm{Au}$ e $\mathrm{Ag}$ e, em menor proporção, $\mathrm{Sb}, \mathrm{As}, \mathrm{Pb}, \mathrm{Hg}$ e W) e sequências sedimentares (formações ferríferas, carbonatos, barita, depósitos de placer de ouro e estanho, bem como ocorrências estratiformes singenéticas de ouro). Mineralizações inicialmente restritas a rochas graníticas, relacionadas a pegmatitos e veios tardios (estanho, tântalo, berilo, lítio, bismuto, mica, molibdênio, córindon e esmeraldas) também podem ser reconhecidas nos terrenos granito-greenstone. Adicionamente, depósitos auríferos com controle estrutural importante podem ter sido formados na fase final de deformação destas rochas.

De acordo com Condie (1981), os principais depósitos minerais entre os vários encontrados em greenstone belts arqueanos são os de $\mathrm{Au}, \mathrm{Cu}, \mathrm{Ni}, \mathrm{Cr}$ e $\mathrm{Fe}$ do tipo estratiforme. $\mathrm{O}$ cobre ocorre comumente associado ao $\mathrm{Zn}, \mathrm{Pb}, \mathrm{Au}$ e $\mathrm{Ni}$ em rochas vulcânicas andesíticas, como no greenstone belt Abitibi, no Canadá. Os principais minerais desses depósitos são calcopirita, pirita, esfalerita e pirrotita e os depósitos podem ser gerados por processos hidrotermais, incluindo-se aqueles relativos aos processos vulcânicos exalativos que caracterizam os depósitos de sulfetos maciços de $\mathrm{Cu}-(\mathrm{Zn}-\mathrm{Pb})$ hospedados em rochas vulcânicas dos tipos VMS ou VHMS (volcanic-hosted massive sulphide; Condie 1981).

O níquel é comumente associado às rochas ultramáficas e pode ser remobilizado em zonas de cisalhamento. A origem desses depósitos é atribuída a processos magmáticos primários, embora alteração hidrotermal e serpentinização também sejam indentificados em alguns depósitos (Condie 1981). Os processos ortomagmáticos incluiriam segregação de um líquido sulfetado imiscível e processos de contaminação crustal, que contribui com uma fonte adicional de enxofre comumente necessária à formação dos depósitos de níquel sulfetado (Naldrett 2004). As mineralizações de cromita são encontradas geralmente em rochas máficas e ultramáficas.

Os depósitos de ferro estão concentrados nas formações ferríferas bandadas do tipo Algoma associadas a rochas vulcânicas. A mineralização encontra-se dividida em quatro Dissertação de Mestrado - IG-USP - Soraya Damasceno Sousa - 2014 
fácies diferentes: (1) fácies oxidada, com a presença de hematita e magnetita; (2) fácies carbonática, onde siderita, ankerita, dolomita e calcita como minerais principais; (3) fácies silicática, caracterizada por silicatos ricos em ferro e (4) fácies sulfetada, onde pirita e pirrotita estão alternadas com níveis de chert.

Os depósitos auríferos incluem depósitos orogênicos hospedados comumente em sequências de greenstone belts localizados ao longo de zonas de cisalhamento, relacionados à circulação regional de fluidos metamórficos associados à evolução dos orógenos, ou seja, ao tectonismo em margens convergentes (Groves et al. 1998, Goldfarb et al. 2001). A formação dos depósitos orogênicos de ouro é considerada como predominantemente posterior ao metamorfismo regional da sequência greenstone belt, tardi-tectônica em relação ao desenvolvimento da zona de cisalhamento e pode ser associada ao magmatismo granítico. Uma importante época metalogenética refere-se ao intervalo entre ca. 2,8-2,55 Ga (Goldfarb et al., 2001), sendo considerada extremamente favorável para a formação de depósitos auríferos orogênicos, como os reconhecidos em sequências de greenstones dos crátons Yilgarn, na Austrália, Dharwar, na India, Slave, no Canadá, São Francisco, no Brasil, e Tanzânia. Esses depósitos ocorrem principalmente nas bordas dos greenstone belts e plútons graníticos, em geral, associados a veios de quartzo controlados por zonas de cisalhamento.

Embora haja um vínculo genético entre os tipos de mineralização e a composição da rocha hospedeira, ainda se tenta entender porque em algumas regiões a mineralização é mais prevalecente que em outras. Exemplo disso são os depósitos de sulfeto de níquel em sequências máficas-ultramáficas no Bloco Yilgarn e que são relativamente ausentes no greenstone belt Barberton, onde rochas com essa associação são extremamente desenvolvidas. Nesse caso, a natureza da configuração geotectônica pode ter contribuído para as diferenças, conforme Anhaeusser (1981) e Naldrett (2004).

Anhaeusser (1981) também ressalta que em terrenos granito-greenstone, além dos depósitos primários sensu stricto, depósitos secundários formados por resultado de superimposição de processos agindo sobre as rochas hospedeiras durante ou subsequente à sua formação e deposição são importantes. Um bom exemplo disso é o asbesto crisotila, que provavelmente não se desenvolveu na rocha hospedeira (dunito), primeira a se cristalizar, mas depois, seguindo (1) serpentinização dos dunitos e (2) movimentos tectônicos, que são o prérequisito para a formação das fibras.

Este mesmo conceito pode ser aplicado para muitos outros depósitos minerais arqueanos, incluindo ouro. Em alguns casos, as concentrações minerais são devidas a fatores primários, como diferenciação magmática ou imiscibilidade de sulfetos-silicatos (Anhaeusser, 1981). 


\section{CONTEXTO GEOLÓGICO REGIONAL}

A Província Carajás (PC), localizada no sudeste do Cráton Amazônico (Almeida et al. 1981), é parte da Província Amazônia Central, de acordo com a compartimentação de províncias tectônicas de Tassinari \& Macambira (2004). Segundo esses autores, o Cráton Amazônico é dividido em províncias geocronológicas, formadas em torno de um núcleo arqueano alongado na direção NW/SE, seguido de retrabalhamentos e acresção crustal ao longo de cinturões móveis (Fig. 07).

De acordo com Santos et al. (2006), a porção sudeste da Província Amazônia Central corresponderia à Província Carajás que seria integralmente formada durante o Arqueano. Modelos mais recentes restringem a Província Carajás até o sul do Domínio Bacajá, correspondente ao extremo sul das províncias Transamazonas (Santos et al. 2006) ou MaroniItacaiunas (Tassinari \& Macambira 2004). Todavia, há um consenso entre esses autores, que a região de Carajás constitui o núcleo arqueano mais antigo desse cráton (Fig. 07).

No que diz respeito às províncias minerais, a PC é considerada hoje a principal província mineral do Brasil, apresentando uma das maiores concentrações de minério de ferro, cobre, níquel, manganês, EGP, crômio e ouro do planeta (Galarza et al. 2002a). É limitada a oeste por unidades da Província Ventuari-Tapajós (Tassinari \& Macambira 2004) e ao leste pelo Cinturão Araguaia, neoproterozóico, formado durante o Brasiliano (PanAfricano), ao norte e ao sul, pela Província Maroni-Itacaiúnas e pelo Domínio Santana do Araguaia (Vasquez et al. 2008b), respectivamente, ambos formados entre 2,20 e 2,10 Ga (Almeida 2010; Fig. 10).

Com base nas idades dos eventos magmáticos e deformacionais, bem como na natureza e idade das supracrustais e seus ambientes tectônicos, a PC foi dividida tectonicamente em: (1) Domínio Rio Maria, ao sul, estabilizado no Mesoarqueano e com idades de 3,00 a 2,86 Ga; e (2) Domínio Carajás, ao norte, caracterizado por intenso retrabalhamento e magmatismo neoarqueano com idades entre 2,76 e 2,74 Ga (Vasquez et al., 2008). A região entre esses dois domínios, anteriormente denominada de Subdomínio de Transição (Dall'Agnol et al. 2006; Feio 2011), foi dividida recentemente por Dall'Agnol et al. (2013), em dois outros domínios: Domínio Canaã, ao sul do Domínio Carajás e Domínio Sapucaia, ao norte do Domínio Rio Maria. 
a)

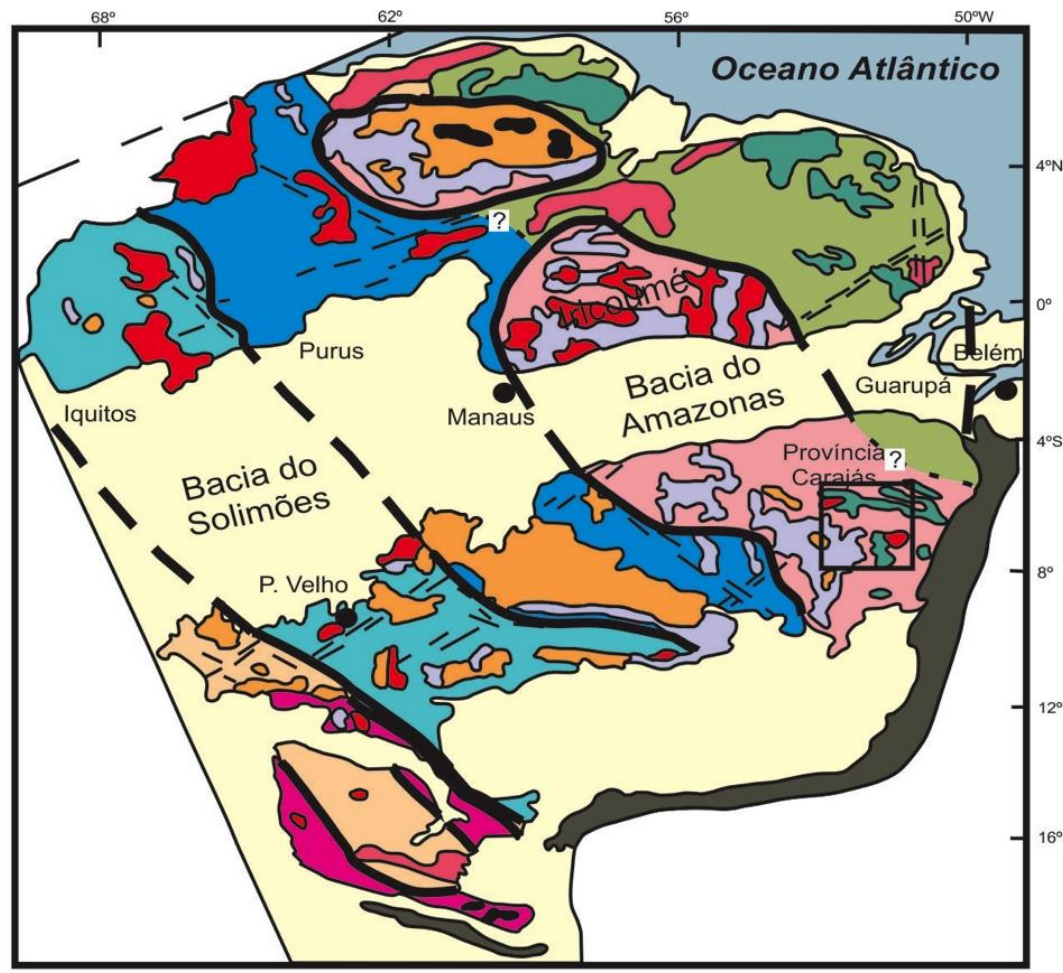

PROVÍNCIAS GEOCRONOLÓGICAS

$\square$ Amazônia Central > 2,3 Ga

$\square$ Maroni - Itacaiúnas 2,2 - 1,95 Ga

$\square$ Ventuari - Tapajós 1,95 - 1,0 Ga

$\square$ Rio Negro - Juruena 1,8 - 1,55 Ga

$\square$ Rondoniana-San Ignácio 1,5 - 1,3 Ga

$\square$ Sunsás 1,25 - 1,0 Ga
UNIDADES GEOLÓGICAS

\section{$\square$ Coberturas Fanerozóicas}

$\square$ Granitóides

Coberturas Sedimentares Precambrianas

$\square$ Coberturas Vulcânicas Ácida-Intermediária

- Vulcânismo Básico

$\square$ Greenstone Belts

$\square$ Complexos Granuliticos

Cinturōes Móveis Neo-Proterozóico

- - Altos Estruturais do Embasamento b)

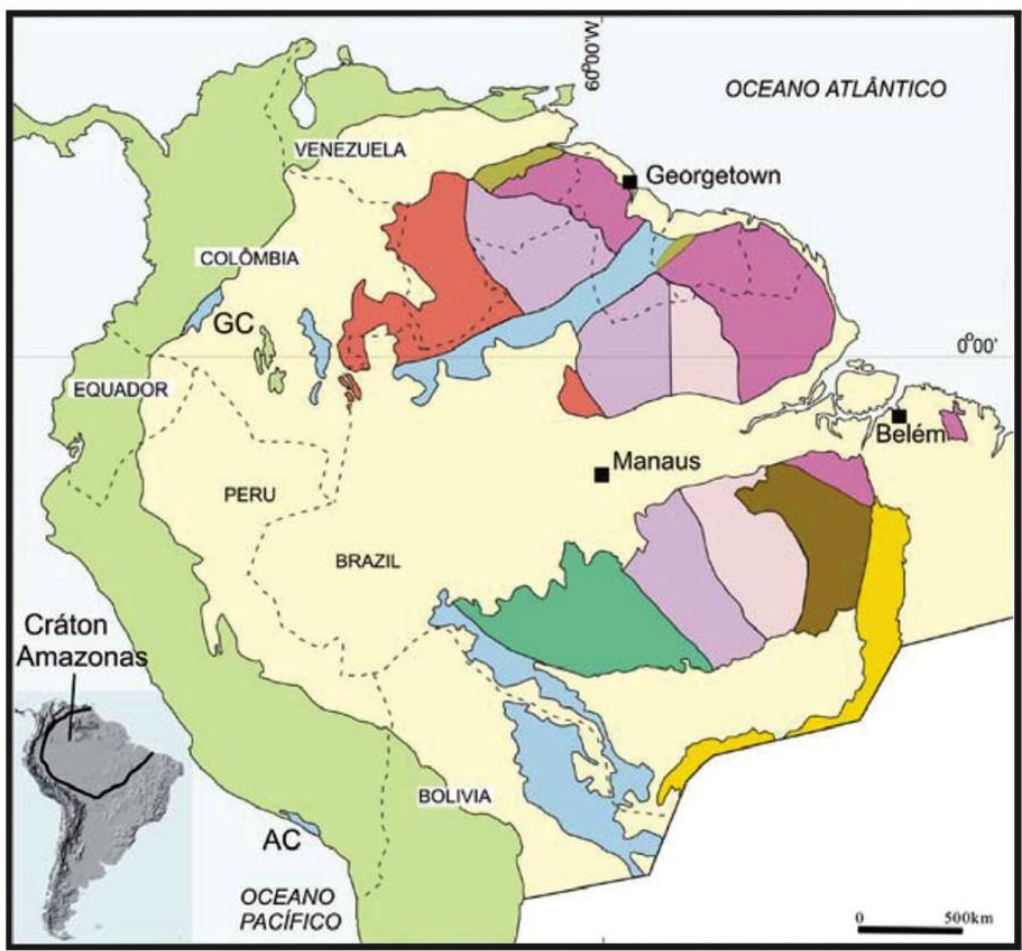

PROVÍNCIAS GEOCRONOLÓGICAS

\section{Sunsás e K'Mudku - 1.45-1.10 Ga}

Rondônia-Juruena - 1.82-1.54 Ga

Rio Negro - 1.82-1.52 Ga

UNIDADES GEOLÓGICAS

$$
\begin{aligned}
& \text { Faixa Orogênica Andes } \\
& \text { Faixa Orogênica Araguaia } \\
& \text { Coberturas Fanerozóicas }
\end{aligned}
$$

Tapajós-Parima - 2.03-1.88 Ga

Transamazonas - 2.26-2.01 Ga

Amazônia Central - supostamente arqueana

Carajás - 3.0-2.5 Ga

Figura 7. Províncias geocronológicas do Cráton Amazonas de acordo com as propostas de a) Tassinari \& Macambira (2004), e b) Santos et al. (2006). 


\subsection{CONTEXTO GEOLÓGICO DO DOMÍNIO RIO MARIA}

Localizado na porção sul da Província Carajás, o Domínio Rio Maria constitui um terreno granito-greenstone arqueano (Fig. 08). Este terreno é composto por associações mesoarqueanas de greenstone belts, complexos máfico-ultramáficos, granitoides, incluindo sanukitoides e ortognaisses TTG, além de granitos de alto potássio (Souza et al. 1996, 2001, Oliveira et al. 2009, Oliveira et al. 2010, Almeida et al. 2011, Dall’Agnol et al. 2013). Neste domínio também ocorrem associações de bacias sedimentares paleoproterozoicas, bem como granitos, diques félsicos e máficos relacionados ao magmatismo anorogênico do Orosiriano (Vasquez et al. 2008b).

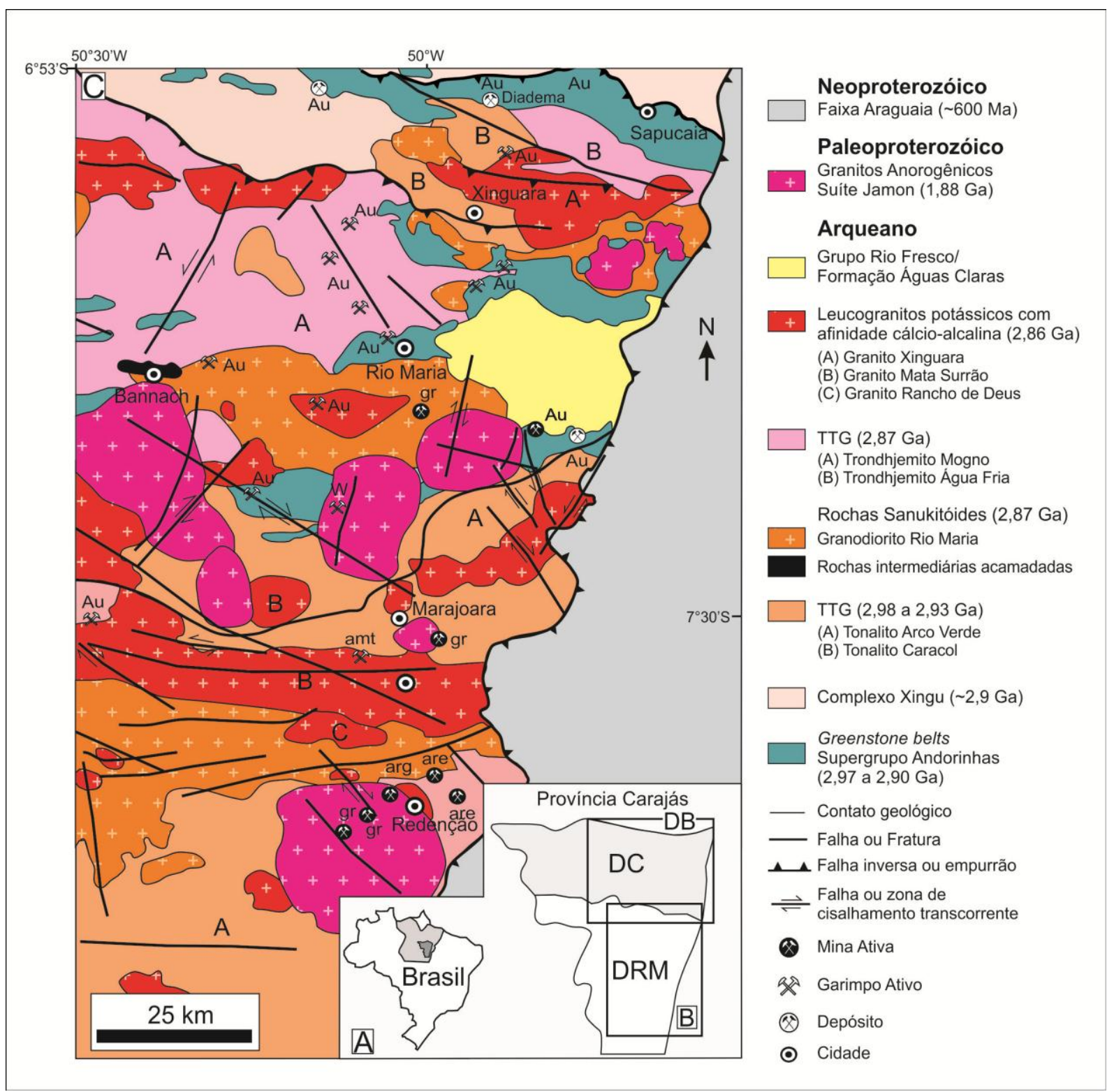

Figura 8. (A) Localização da Província Carajás no Estado do Pará; (B) Divisão da Província Carajás nos Domínios Rio Maria (DRM), ao sul, e Carajás (DC), que é limitado ao norte pelo Domínio Bacajá (DB); (C) Mapa geológico do Domínio Rio Maria (modificado de Vasquez et al. 2008b e Almeida et al. 2011). 
Os greenstone belts do Domínio Rio Maria são formados por sequências vulcanossedimentares (Sapucaia, Identidade, Lagoa Seca, Babaçu, Seringa, Pedra Preta e Tucumã) metamorfisadas em condições de fácies xisto-verde a anfibolito (Souza et al., 1996, 2001) e, inicialmente, agrupadas no Supergrupo Andorinhas (Huhn et al. 1988, DOCEGEO 1988).

Vasquez et al. (2008b) não adotaram o termo Supergrupo Andorinhas e dividiram as sequências greenstone belts do Domínio Rio Maria em seis grupos: Gradaús, Serra do Inajá, Babaçu, Lagoa Seca, Sapucaia e Tucumã.

O Grupo Gradaús foi caracterizado por Macambira et al. (1986) e depois por Santos \& Pena Filho (2000) como uma sequência metavulcanossedimentar tipo greenstone belt, dobrada e metamorfisada em fácies xisto verde. Este grupo é constituído por duas sequências: uma inferior, com rochas metaultramáficas (serpentinitos e talco xistos), metavulcânicas máficas (metabasaltos, metagabros e metadiabásios) e intermediárias a ácidas (metadacitos, pórfiros riodacíticos e metarriolitos associados a metatufos cineríticos), com rochas metassedimentares químicas subordinadas; e a superior, com rochas metassedimentares clásticas e químicas, com rochas metavulcânicas intermediárias e ácidas (metadacitos, metariodacitos, metarriolitos associadas a metatufos) subordinadas.

As rochas do Grupo Inajá foram caracterizadas e agrupadas por Ianhez et al. (1980) em quatro associações litológicas constituídas, da base para o topo, por: 1) rochas predominantemente metaultramáficas, incluindo serpentinitos, metaperidotitos e esteatitos, com actinolititos e clorititos associados; 2) rochas metamáficas e intermediárias (quartzo monzodioritos a monzogabros e metandesitos); 3) metatufos riodacíticos; e 4) rochas metassedimentares (quartzitos, metabrechas, formações ferríferas, metacherts, concentrações manganesíferas e hornfels carbonáticos - mármores).

O Grupo Babaçu refere-se à Sequência Babaçu de Cordeiro \& Saueressig (1980), que foi descrita como uma sequência vulcanossedimentar tipo greenstone belt, composta por extensos derrames de metabasaltos, intercalados predominantemente a rochas metassedimentares químicas, além de metatufos e talco xistos. A porção inferior foi designada de Formação Igarapé Encantado, que segundo Vasquez et al. (2008b), corresponde ao Grupo Tucumã que ocorre na região a sul da Serra da Seringa. Os grupos Babaçu e Lagoa Seca representam a parte inferior e superior, respectivamente, de uma mesma sequência greenstone belt, denominada como Grupo Andorinhas por Santos \& Pena Filho (2000). De acordo com as descrições de Cordeiro \& Saueressig (1980), Cordeiro (1982), Docegeo (1988), Huhn et al. (1988), Santos \& Pena Filho (2000) e Souza et al. (1988, 2001), os metabasaltos são tholeiíticos, maciços, com texturas ígneas reliquiares, variolíticas e com pillow lavas com 
material interpillow fino com vidro devitrificado. Os metatufos são representados por cloritasericita xistos, com quantidades variáveis de quartzo, carbonato, pirita, pirrotita e magnetita. As rochas metaultramáficas (xistos com tremolita, talco e clorita) ocorrem como intercalações ao longo de todo o pacote e apresentam relíquias de textura spinifex, sendo classificadas como komatiítos piroxeníticos. A porção superior é constituída predominantemente por rochas metassedimentares químicas. Metacherts ocorrem em pequenas lentes com turmalina, hidróxido de manganês, pirita, carbonatos recristalizados e ouro livre, enquanto as formações ferríferas bandadas ocorrem como lentes ou camadas quilométricas, formadas por intercalações de hematita e sílica. Metapelitos classificados como clorita e quartzo-sericita xistos também são descritos nesta sequência.

Souza et al. (1988, 2001), na região a sudeste de Xinguara, atribuíram os litotipos dessa unidade ao Greenstone Belt de Identidade, constituído predominantemente por rochas metavulcânicas máficas e félsicas, com metaultramáficas e metassedimentares químicas subordinadas, e onde são descritas ocorrências de pillow lavas.

O Grupo Lagoa Seca foi definido por Docegeo (1988) e reúne uma sequência de rochas metavulcânicas félsicas (metandesitos, metadacitos/metariodacitos) intercaladas com rochas metassedimentares, e outra sequência com predomínio de rochas metassedimentares (metagrauvacas, metassiltitos e metarenitos), intercaladas com rochas metavulcânicas máficas (metabasaltos, tremolita-actinolita e hornblenda-epidoto xistos), metaultramáficas (talco xistos) e níveis de formação ferrífera bandada.

As rochas do greenstone belt Tucumã, caracterizadas inicialmente por Cordeiro (1982) e Huhn et al. (1986 e 1988) como pertencentes ao greenstone belt Seringa, foram individualizadas como Grupo Tucumã por Araújo \& Maia (1991). Segundo Araújo \& Maia (1991), Macambira \& Vale (1997), Santos \& Pena Filho (2000), o Grupo Tucumã é constituído por rochas metamáficas (anfibolitos e xistos com actinolita, tremolita e clorita), metaultramáficas (serpentinitos, metaperidotitos, metapiroxenitos e xistos com antofilita, cordierita e talco), metavulcânicas ácidas (metadacitos associados a xistos com sericita, biotita e quartzo) e metassedimentares psamo-pelíticas com subordinadas intercalações de metamafitos e metavulcânicas félsicas. Na porção metassedimentar são descritos filitos, biotita xistos, clorita xistos, biotita-muscovita xistos, quartzitos micáceos, metarenitos, metarcóseos, metagrauvacas, formações ferríferas bandadas e, ocasionalmente, rochas conglomeráticas com clastos de quartzo e fragmentos de rochas metamorfisadas em fácies xisto-verde.

O Grupo Sapucaia foi citado a primeira vez por Cordeiro (1982) e Hirata et al. (1982) e formalizado por Araújo \& Maia (1991). Esses autores descreveram textura spinifex em Dissertação de Mestrado - IG-USP - Soraya Damasceno Sousa - 2014 
rochas metaultramáficas nas proximidades do Igarapé Sapucaia. Segundo Araújo \& Maia (1991), o Grupo Sapucaia inclui rochas metaultramáficas (serpentinitos e xistos com actinolita, tremolita, clorita, talco, antigorita, crisotila, antofilita e opacos) com afinidade komatiítica e textura spinifex, metamáficas (xistos actinolíticos), metadacitos e rochas metassedimentares. As rochas metassedimentares são representadas por xistos micáceos e quartzosos (com quartzo, muscovita, clorita, biotita, albita, epidoto, sillimanita, cianita e andaluzita) com subordinados níveis de quartzitos (com clorita, muscovita e sericita) e de formações ferríferas bandadas fácies óxido. Santos \& Pena Filho (2000) reconheceram apenas a sequência mais basal do Grupo Sapucaia na porção sudeste deste grupo, representada por metaultramafitos que incluem clorita-grunerita xistos e metaperidotitos (lherzolitos) com texturas ígneas preservadas. Segundo os vários autores citados acima, as rochas deste grupo apresentam metamorfismo em fácies xisto verde, com uma forte anisotropia estrutural, com xistosidade ou foliação milonítica pronunciada, além de serem cortadas por zonas de cavalgamento oblíquas e transcorrências associadas. O Grupo Sapucaia seria correlacionável às sequências greenstone belts com idades de 3,00 Ga ou 2,87 Ga que ocorrem neste domínio, visto que inexistem dados geocronológicos para essa unidade.

O Complexo Máfico-ultramáfico Serra Azul é composto por dunitos cumuláticos, piroxenitos, peridotitos, gabros e anortositos. Os peridotitos são serpentinizados e constituídos por pseudomorfos de fases cumulus constituídos por serpentina e tremolita e intercumulus com diopsídio transformado para tremolita + talco + clorita + hornblenda, clorita e opacos. Os piroxenitos contêm cumulus de diopsídio, além de carbonato e clorita. Os gabros apresentam diopsídio, plagioclásio saussuritizado, tremolita, clorita e carbonatos (DOCEGEO, 1988).

O Complexo Máfico-Ultramáfico Guara-Pará (Macambira et al. 1986) correspondem a olivina gabros com textura subofítica, constituídos por plagioclásio, clinopiroxênio, hornblenda, tremolita-actinolita, olivina, além de clorita, zoisita, opacos, carbonatos e titanita (Santos 1995). As rochas ultramáficas são dunitos e peridotitos serpentinizados, maciços, por vezes com veios de crisotila fibrosa, dando um aspecto bandado à rocha; cumulus de olivina serpentinizada, piroxênio parcialmente serpentinizado como intercumulus, hornblenda, clorita, opacos e carbonatos (Macambira et al. 1986, Santos 1995).

Os TTGs do Domínio Rio Maria são constituídos por uma série mais antiga, representada pelas rochas mais antigas do Tonalito Arco Verde e pelo Thondjemito Mogno (Almeida et al. 2011). A série TTG mais jovem é composta pelos tonalitos Caracol, Mariazinha e Parazônia, respectivamente (Leite et al 2010). Até hoje não foram observadas relações de contato entre o Tonalito Arco Verde e as sequências de greenstone belts. 
O Trondhjemito Mogno, que ocorre a sul de Xinguara e se estende até o norte de Bannach, contém enclaves máficos interpretados como metabasaltos do Supergrupo Andorinhas (Souza 1994). O Trondhjemito Água Fria representa a geração mais jovem de TTG descrito no Domínio Rio Maria. Exibe bandamento subvertical com direção NW-SE e WNW-ESSE, inclue enclaves tonalíticos e associa-se concordantemente com leucogranitos relacionados ao Granito Xinguara (Leite 2001). Foram obtidas idades (tabela 01) de $2.864 \pm$ $21 \mathrm{Ma}(\mathrm{Pb}-\mathrm{Pb}$ em zircão, Leite et al. 2004) e $2.843 \pm 10$ Ma (LA-MC-ICPMS em zircão, Almeida et al. 2011) para o Trondhjemito Água Fria, o que levou ao seu posicionamento estratigráfico no final da evolução do Domínio Rio Maria.

Rochas granitoides ricas em magnésio, representadas pelo Granodiorito Rio Maria (Medeiros \& Dall'Agnol, 1988; Oliveira et al. 2006) e rochas associadas, apresentam assinatura sanukitóide. Incluem dominantemente rochas granodioríticas, subordinadamente monzogranitos e quartzo-dioritos ou quartzo-monzodioritos (rochas intermediárias), além de rochas acamadadas e enclaves máficos. O Granodiorito Rio Maria é enriquecido em $\mathrm{Ca}, \mathrm{Mg}$ e $\mathrm{K}$, além de $\mathrm{Cr}$ e $\mathrm{Ni}$, aproximando-se geoquimicamente das séries sanukitóides arqueanas definidas por Stern et al. (1989). Os padrões de elementos terras raras também são desprovidos de anomalias significativas de $\mathrm{Eu}$ e são fortemente fracionados, porém o empobrecimento de elementos terras raras pesados é menos pronunciado em relação ao padrão típico dos TTG (Dall'Agnol et al. 2006, Oliveira et al. 2009a, Almeida et al. 2011). A Suíte Guarantã representada pelos plútons Guarantã, Azulona e Trairão (Dias 2009; Almeida et al. 2010) constituídos dominantemente por biotita-leucogranodioritos e biotitaleucomonzogranitos porfiríticos e pelo leucogranito Rancho de Deus, composto por rochas monzograníticas porfirítica, cuja principal diferença em relação aos outros grupos de leucogranitos é a constante presença de anfibólio modal (Dias 2009; Almeida et al. 2010).

Leucogranitos potássicos são representados no Domínio Rio Maria principalmente pelos granitos Xinguara, intrusivo nos greenstone belts, no Complexo Tonalítico Caracol, Tonalito Mariazinha e Granodiorito Rio Maria (Leite et al. 1997) e Mata Surrão (Duarte et al. 1991, Althoff et al. 2000) e por pequenos stocks graníticos.

A Suíte Intrusiva Jamon é composta pelos granitos Jamon, Bannach, Cachoeirinha, Gradaús, Manda Saia, Marajoara, Musa, Redenção, São João e Seringa. Estes corpos são intrusivos, indiscriminadamente, em todas as unidades do Domínio Rio Maria. São granitos de coloração rosada, avermelhada ou acinzentada, leuco a hololeucocráticos, de granulação média a grossa, localmente fina ou pegmatóide, com textura equigranular a heterogranular, apresentando localmente textura porfirítica, inclusive rapakivi, petrograficamente são caracterizados como sienogranitos, monzogranitos e álcalifeldspato granitos. Representa um Dissertação de Mestrado - IG-USP - Soraya Damasceno Sousa - 2014 
expressivo magmatismo de natureza subalcalina, metaluminosa a peraluminosa, com assinatura geoquímica de granitos intraplaca tipo-A (Almeida 2005, Dall’́Agnol et al. 1999a) do orosiriano no Domínio Rio Maria.

As coberturas sedimentares paleoproterozoicas são representadas pelos grupos Rio Fresco e Gemaque. Estas coberturas são compostas por sucessões psefito-psamíticas na base e pelito-carbonáticas no topo, por vezes incipientemente metamorfisadas e localmente dobradas, que marcam transgressões marinhas sobre sedimentos de ambientes costeiros e continentais (Marinho et al. 1977, Cunha et al. 1984, Ramos et al. 1984, Macambira et al. 1986, Santos \& Pena Filho, 2000). Ainda não há um consenso sobre a posição estratigráfica dessas sequências sedimentares, por isso Vasquez et al. (2008b) as posicionaram entre o Sideriano e o Riaciano, período no qual os domínios arqueanos desta província se consolidaram como uma área de plataforma continental estável.

A Formação Gorotire representaria outro conjunto de cobertura sedimentar paleoproterozóica, marcada por sedimentação psamítica quartzosa e arcoseana de ambiente continental, que sucedeu a sedimentação plataformal do Grupo Rio Fresco. Estudando essa mesma sequência sedimentar no Domínio Santana do Araguaia, ao sul do Domínio Rio Maria, Monteiro et al. (2004) obtiveram uma idade máxima de deposição de 2,03 Ga, através do método de evaporação de zircão. 
Tabela 1 - Síntese dos dados geocronológicos das unidades do Domínio Rio Maria.

\begin{tabular}{|c|c|c|c|c|}
\hline Unidade Estratigráfica & Método & $\begin{array}{l}\text { Material } \\
\text { Analisado }\end{array}$ & Idade & Referência \\
\hline \multicolumn{5}{|l|}{ Suíte intrusiva Jamon } \\
\hline $\begin{array}{l}\text { Musa } \\
\text { Jamon } \\
\text { Seringa } \\
\text { Redenção } \\
\text { Diques félsicos }\end{array}$ & $\begin{array}{l}\mathrm{U}-\mathrm{Pb} \\
\mathrm{Pb}-\mathrm{Pb} \\
\mathrm{Pb}-\mathrm{Pb} \\
\mathrm{Pb}-\mathrm{Pb} \\
\mathrm{Pb}-\mathrm{Pb}\end{array}$ & $\begin{array}{l}\text { Zircão } \\
\text { Zircão } \\
\text { Zircão } \\
\text { Rocha total } \\
\text { Zircão }\end{array}$ & $\begin{array}{l}1.883 \pm 5 /-2 \mathrm{Ma} \\
1.885 \pm 32 \mathrm{Ma} \\
1.893 \pm 15 \mathrm{Ma} \\
1.870 \pm 68 \mathrm{Ma} \\
1.885 \pm 4 \mathrm{Ma} \\
\end{array}$ & $\begin{array}{l}\text { Machado et al. } 1991 \\
\text { Dall' Agnol et al. } 1999 \\
\text { Avelar et al. } 1999 \\
\text { Barbosa } \text { et al. } 1995 \\
\text { Oliveira et al. } 2002 \\
\end{array}$ \\
\hline \multicolumn{5}{|l|}{ Leucogranitos Potássicos } \\
\hline Granito Mata Surrão & $\begin{array}{l}\mathrm{Pb}-\mathrm{Pb} \\
\mathrm{Pb}-\mathrm{Pb} \\
\mathrm{Pb}-\mathrm{Pb}\end{array}$ & $\begin{array}{l}\text { Roc Total } \\
\text { Zircão } \\
\text { Zircão } \\
\end{array}$ & $\begin{array}{l}2.872 \pm 10 \mathrm{Ma} \\
2.875 \pm 11 \mathrm{Ma} \\
2.881 \pm 2 \mathrm{Ma} \\
\end{array}$ & $\begin{array}{l}\text { Lafon et al. } 1994 \\
\text { Rolando \& Macambira } 2003 \\
\text { Rolando \& Macambira } 2003\end{array}$ \\
\hline Trondhjemito Água Fria & $\mathrm{Pb}-\mathrm{Pb}$ & Zircão & $\begin{array}{l}2.864 \pm 21 \mathrm{Ma} \\
2.854 \pm 17 \mathrm{Ma}\end{array}$ & $\begin{array}{l}\text { Leite } \text { et al. } 2004 \\
\text { Almeida } \text { et al. } 2011\end{array}$ \\
\hline Granito Xinguara & $\mathrm{Pb}-\mathrm{Pb}$ & Zircão & $2.865 \pm 1 \mathrm{Ma}$ & Leite et al. 2004 \\
\hline \multicolumn{5}{|c|}{ Grupo dos Leucogranodioritos-leucogranitos } \\
\hline $\begin{array}{l}\text { Suíte Guarantã } \\
\text { Granito Rancho de Deus }\end{array}$ & $\begin{array}{l}\mathrm{Pb}-\mathrm{Pb} \\
\mathrm{Pb}-\mathrm{Pb} \\
\mathrm{Pb}-\mathrm{Pb} \\
\mathrm{U}-\mathrm{Pb} \\
\mathrm{U}-\mathrm{Pb} \\
\mathrm{U}-\mathrm{Pb} \\
\end{array}$ & $\begin{array}{l}\text { Zircão } \\
\text { Zircão } \\
\text { Zircão } \\
\text { Zircão } \\
\text { Zircão } \\
\text { Zircão } \\
\end{array}$ & $\begin{array}{l}2.868 \pm 5 \mathrm{Ma} \\
2.870 \pm 5 \mathrm{Ma} \\
2.864 \pm 8 \mathrm{Ma} \\
2.875 \pm 8 \mathrm{Ma} \\
2.872 \pm 7 \mathrm{Ma} \\
2.888 \pm 27 \mathrm{Ma} \\
\end{array}$ & $\begin{array}{l}\text { Althoff } \text { et al. } 2000 \\
\text { Almeida } \text { et al. } 2011 \\
\text { Almeida } \text { et al. } 2011 \\
\text { Almeida } \text { et al. } 2011 \\
\text { Almeida } \text { et al. } 2011 \\
\text { Almeida } \text { et al. } 2011 \\
\end{array}$ \\
\hline \multicolumn{5}{|l|}{ Sanukitóides } \\
\hline $\begin{array}{l}\text { Suíte Sanukitóide Rio Maria e } \\
\text { rochas associadas }\end{array}$ & $\begin{array}{l}\mathrm{U}-\mathrm{Pb} \\
\mathrm{U}-\mathrm{Pb} \\
\mathrm{Pb}-\mathrm{Pb} \\
\mathrm{Pb}-\mathrm{Pb} \\
\end{array}$ & $\begin{array}{l}\text { Zircão } \\
\text { Zircão } \\
\text { Zircão } \\
\text { Zircão } \\
\end{array}$ & $\begin{array}{l}2.874 \pm 9 \mathrm{Ma} \\
2.872 \pm 5 \mathrm{Ma} \\
2.877 \pm 6 \mathrm{Ma} \\
2.878 \pm 4 \mathrm{Ma} \\
\end{array}$ & $\begin{array}{l}\text { Macambira \& Lancelot } 1991 \\
\text { Pimentel \& Machado } 1994 \\
\text { Rolando \& Macambira } 2003 \\
\text { Dall' Agnol et al. } 1999\end{array}$ \\
\hline \multicolumn{5}{|l|}{ Série TTG mais jovem } \\
\hline Tonalito Parazônia & $\begin{array}{l}\mathrm{Pb}-\mathrm{Pb} \\
\mathrm{U}-\mathrm{Pb}\end{array}$ & $\begin{array}{l}\text { Zircão } \\
\text { Titanita } \\
\end{array}$ & $\begin{array}{l}2.876 \pm 2 \mathrm{Ma} \\
2.858 \mathrm{Ma} \\
\end{array}$ & $\begin{array}{l}\text { Almeida } \text { et al. } 2010 \\
\text { Pimentel \& Machado } 1994\end{array}$ \\
\hline Tonalito Mariazinha & $\begin{array}{l}\mathrm{U}-\mathrm{Pb} \\
\mathrm{U}-\mathrm{Pb}\end{array}$ & $\begin{array}{l}\text { Zircão } \\
\text { Zircão }\end{array}$ & $\begin{array}{l}2.925 \pm 3 \mathrm{Ma} \\
2.918 \pm 13 \mathrm{Ma}\end{array}$ & $\begin{array}{l}\text { Almeida } \text { et al. } 2011 \\
\text { Almeida } \text { et al. } 2011\end{array}$ \\
\hline Complexo Tonalítico Caracol & $\begin{array}{l}\mathrm{Pb}-\mathrm{Pb} \\
\mathrm{Pb}-\mathrm{Pb}\end{array}$ & $\begin{array}{l}\text { Zircão } \\
\text { Zircão }\end{array}$ & $\begin{array}{l}2.948 \pm 5 \mathrm{Ma} \\
2.936 \pm 3 \mathrm{Ma}\end{array}$ & $\begin{array}{l}\text { Leite } \text { et al. } 2004 \\
\text { Leite } \text { et al. } 2004\end{array}$ \\
\hline \multicolumn{5}{|l|}{ Série TTG mais antiga } \\
\hline Trondhjemito Mogno & $\begin{array}{l}\mathrm{Pb}-\mathrm{Pb} \\
\mathrm{Pb}-\mathrm{Pb} \\
\mathrm{Pb}-\mathrm{Pb} \\
\mathrm{U}-\mathrm{Pb} \\
\mathrm{Pb}-\mathrm{Pb} \\
\mathrm{U}-\mathrm{Pb} \\
\mathrm{Pb}-\mathrm{Pb} \\
\mathrm{Pb}-\mathrm{Pb}\end{array}$ & $\begin{array}{l}\text { Zircão } \\
\text { Zircão } \\
\text { Zircão } \\
\text { Zircão } \\
\text { Zircão } \\
\text { Zircão } \\
\text { Zircão } \\
\text { Zircão }\end{array}$ & $\begin{array}{l}2.857 \pm 13 \mathrm{Ma} \\
2.900 \pm 21 \mathrm{Ma} \\
2.962 \pm 8 \mathrm{Ma} \\
2.965 \pm 7 \mathrm{Ma} \\
2.968 \pm 2 \mathrm{Ma} \\
2.968 \pm 3 \mathrm{Ma} \\
2.959 \pm 5 \mathrm{Ma} \\
2.959 \pm 2 \mathrm{Ma}\end{array}$ & $\begin{array}{l}\text { Macambira et al. } 2000 \\
\text { Macambira et al. } 2000 \\
\text { Almeida } \text { et al. } 2011 \\
\text { Almeida } \text { et al. } 2011 \\
\text { Almeida } \text { et al. } 2011 \\
\text { Almeida } \text { et al. } 2011 \\
\text { Almeida et al. } 2011 \\
\text { Almeida } \text { et al. } 2011\end{array}$ \\
\hline Tonalito Arco Verde & $\begin{array}{l}\mathrm{U}-\mathrm{Pb} \\
\mathrm{Pb}-\mathrm{Pb} \\
\mathrm{Pb}-\mathrm{Pb} \\
\mathrm{Pb}-\mathrm{Pb} \\
\mathrm{U}-\mathrm{Pb} \\
\mathrm{Pb}-\mathrm{Pb} \\
\mathrm{U}-\mathrm{Pb}\end{array}$ & $\begin{array}{l}\text { Zircão } \\
\text { Zircão } \\
\text { Zircão } \\
\text { Zircão } \\
\text { Zircão } \\
\text { Zircão } \\
\text { Zircão }\end{array}$ & $\begin{array}{l}2.964 \pm 4 \mathrm{Ma} \\
2.948 \pm 7 \mathrm{Ma} \\
2.952 \pm 2 \mathrm{Ma} \\
2.926 \pm 2 \mathrm{Ma} \\
2.935 \pm 5 \mathrm{Ma} \\
2.937 \pm 3 \mathrm{Ma} \\
2.973 \pm 11 \mathrm{Ma} \\
\end{array}$ & $\begin{array}{l}\text { Vasquez et al. } 2008 \mathrm{~b} \\
\text { Rolando \& Macambira } 2003 \\
\text { Almeida } \text { et al. } 2011 \\
\text { Almeida } \text { et al. } 2011 \\
\text { Almeida } \text { et al. } 2011 \\
\text { Almeida } \text { et al. } 2011 \\
\text { Almeida } \text { et al. } 2011 \\
\end{array}$ \\
\hline \multicolumn{5}{|l|}{ Complexo Máfico-Ultramáfico } \\
\hline \multicolumn{5}{|l|}{ Greenstone Belts } \\
\hline Grupo Lagoa Seca & $\begin{array}{l}\mathrm{U}-\mathrm{Pb} \\
\mathrm{U}-\mathrm{Pb} \\
\mathrm{U}-\mathrm{Pb}\end{array}$ & $\begin{array}{l}\text { Zircão } \\
\text { Zircão } \\
\text { Zircão }\end{array}$ & $\begin{array}{l}2.904+29 /-22 \mathrm{Ma} \\
2.971 \pm 18 \mathrm{Ma} \\
2.972 \pm 5 \mathrm{Ma} \\
\end{array}$ & $\begin{array}{l}\text { Macambira \& Lancelot } 1996 \\
\text { Macambira \& Lancelot } 1996 \\
\text { Pimentel \& Machado } 1994\end{array}$ \\
\hline Grupo Gradaús & $\mathrm{U}-\mathrm{Pb}$ & Zircão & $3.002 \pm 3 \mathrm{Ma}$ & Tassinari et al. (2005) \\
\hline
\end{tabular}




\subsection{GEOLOGIA DO DOMÍNIO CARAJÁS}

O Domínio Carajás, localizado na porção norte da Província Carajás (Fig. 09), é composto por uma associação de alto grau que representa o embasamento mesoarqueano, granitoides mesoarqueanos diversos, sequências metavulcanossedimentares neoarqueanas e complexos máfico-ultramáficos associados. Associações de granitos neoarqueanos contemporâneos às sequências metavulcanossedimentares também são reconhecidas no domínio. Uma cobertura sedimentar representada por sequências depositadas em plataforma continental neoarqueana recobre as sequências metavulcanossedimentares. Neste domínio, as associações paleoproterozoicas são representadas por corpos máfico-ultramáficos siderianos (Araújo \& Maia 1991) e granitos tipo A orosirianos (Dall'Agnol et al. 2006).

O embasamento mesoarqueano do Domínio Carajás restringe-se à sua porção sul, denominada de Subdomínio de Transição (Dall'Agnol et al. 2006) ou Domínio Canaã dos Carajás (Dall'Agnol et al. 2013), inicialmente agrupadas nos complexos Xingu (Silva et al. 1974), e Pium, de idade $3.002 \pm 14$ Ma (Pidgeon et al. 2000). No entanto, Ricci \& Carvalho (2006) e Santos \& Oliveira (2010) consideraram que o Complexo Pium, em sua área tipo, seria constituído predominantemente por rochas noríticas. Os granulitos máficos, reconhecidas predominantemente na área da aldeia Chicrim-Cateté, foram então denominados de Ortogranulito Chicrim-Cateté (Vasquez et al. 2008b).

O Complexo Xingu compreende uma associação litológica que inclui granulitos, gnaisses, migmatitos, granitoides diversos, faixas de greenstone belts e complexos básicos e ultrabásicos (Cordeiro \& Saueressig 1980, Ianhez et al. 1980, Medeiros Filho \& Meireles 1985, DOCEGEO 1988). Com o avanço do conhecimento geológico, foi possível demonstrar que esse complexo compreende diversos corpos passíveis de serem individualizados. Diversos granitoides mesoarqueanos com idades entre 3,0 e 2,83 Ga foram reconhecidos por Sousa et al. (2010), Moreto et al. (2011), Feio et al. (2012), Gabriel et al. (2012) e Moreto (2013a).

Entre os granitoides mais antigos, foram identificados o Tonalito Bacaba (Moreto et

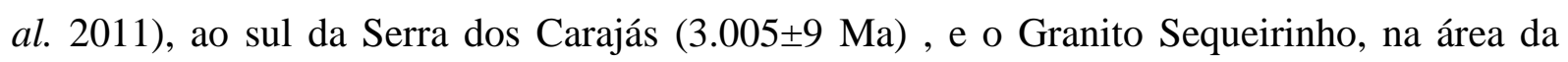
Mina do Sossego (ca. 3,0 Ga; Moreto 2013b). O Granito Canaã dos Carajás é representado por biotita-monzogranitos a granodioritos (2.959 $\pm 6 \mathrm{Ma} ;$ Feio et al. 2013). O Trondhjemito Rio Verde é composto por rochas trondhjemíticas e biotita tonalitos $(2,93 \mathrm{Ga}$; Feio et al., 2012). Os granodioritos Água Azul e Água Limpa representam granitoides de alto $\mathrm{Mg}$ de associação sanukitoide (2.884 \pm 1,7 Ma; Sousa et al. 2010 e $2.879 \pm 1,3 \mathrm{Ma}$, Gabriel et al. 2010, respectivamente). 


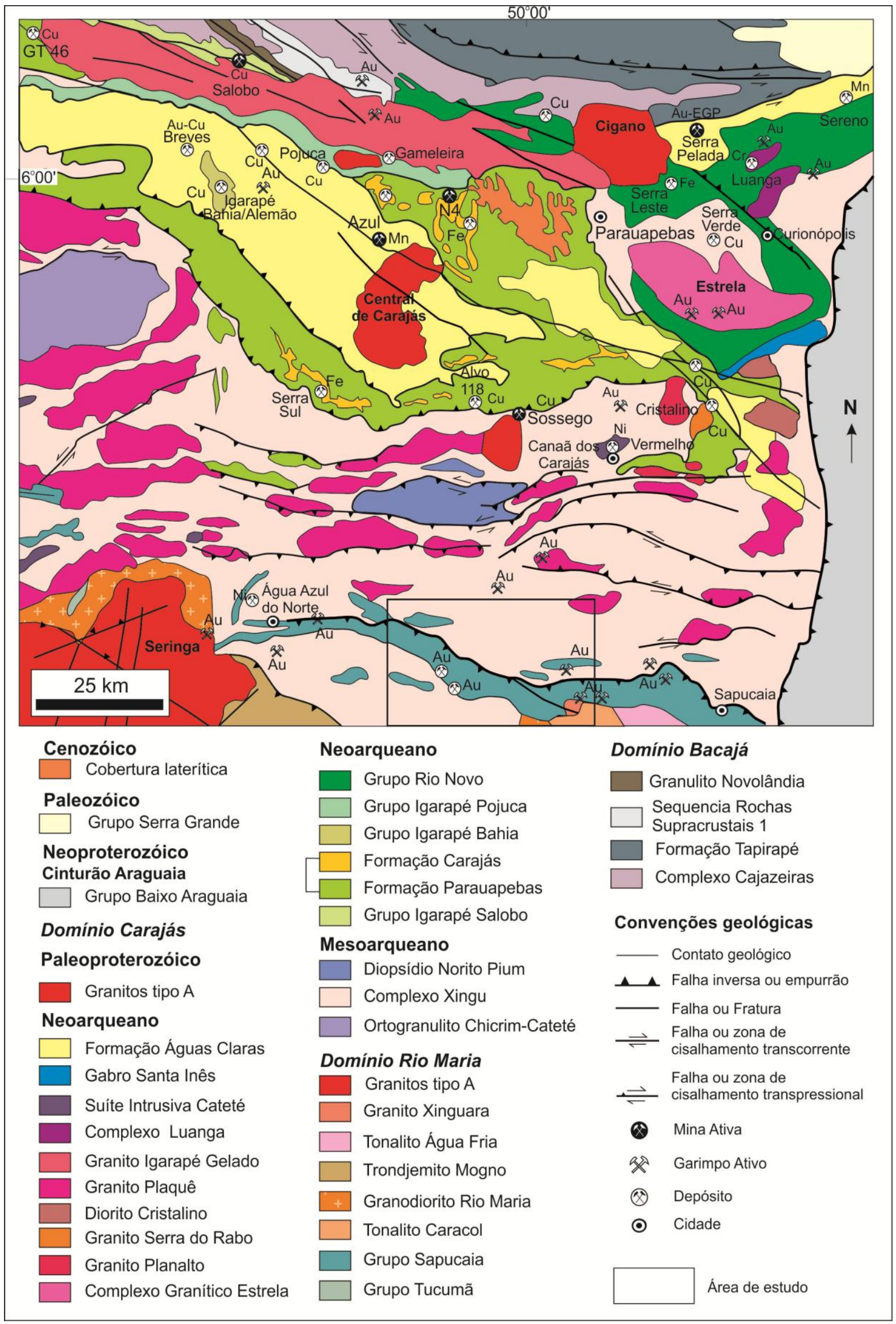

Figura 9. Mapa geológico do Domínio Carajás (Vasquez et al. 2008b). 
Outros granitoides individualizados em áreas antes atribuídas ao Complexo Xingu, incluem o Complexo Tonalítico Campina Verde (Feio et al. 2013) com idades de 2.872 $\pm 1 \mathrm{Ma}$

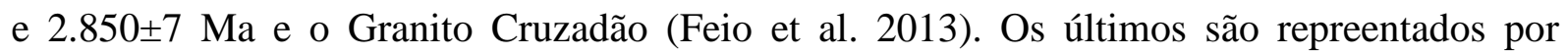
biotita-monzogranito a sienogranito, com assinatura geoquímica transicional entre as das

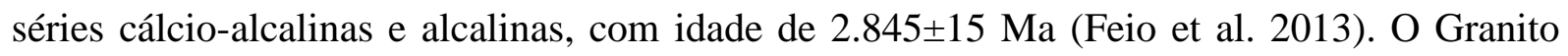
Bom Jesus é composto por monzogranitos e sienogranitos, cuja idade de $2.833 \pm 6 \mathrm{Ma}$ (Feio et al. 2013) é interpretada como idade mínima de cristalização desta unidade. O stock granítico Serra Dourada é constituído por leucomonzogranitos de assinatura cálcio-alcalina e idades

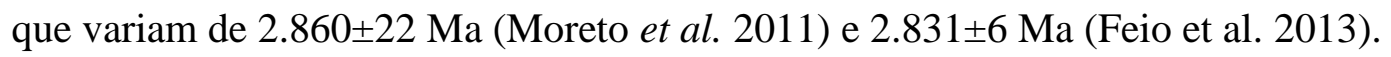

As sequências metavulcanossedimentares do Domínio Carajás foram inicialmente agrupadas no Supergrupo Itacaiúnas (Docegeo 1988) com idades entre 2,76 e 2,73 Ga (Machado et al. 1991, Galarza 2002b, Galarza \& Macambira 2002a, Santos 2002, Pimentel et al. 2003, Tallarico et al. 2005). Entretanto, Vasquez et al. (2008) não adotaram essa terminologia, referindo-se apenas aos grupos que compõem essa unidade. Entre esses grupos, segundo esses autores, são incluídos Igarapé Bahia, Igarapé Salobo, Grão Pará, Igarapé Pojuca, Rio Novo e Aquiri, constituídos predominantemente por rochas vulcânicas máficas, intermediárias e ácidas, associadas a rochas vulcanoclásticas e sedimentares químicas metamorfisadas em fácies xisto verde a anfibolito. Entre as últimas, destacam-se as formações ferríferas do Grupo Grão Pará (Formação Carajás), que hospedam os importantes depósitos de ferro de Carajás. O Grupo São Félix, também metavulcanosedimentar, composto por por rochas metaultramáficas, metamáficas, metavulcânicas ácidas e metassedimentares com idade desconhecida. O Grupo São Sebastião (Macambira \& Vale 1997) é composto por rochas metassedimentares e metamáficas que apresentam idade mínima dada pela Suíte Intrusiva Cateté (2.766 $\pm 6 \mathrm{Ma}$, Lafon et al. 2000) intrusiva nesta unidade.

Entre os granitoides neoarqueanos, o Complexo Granítico Estrela (Barros 1997) é representado predominantemente por monzogranitos com tonalitos, granodioritos e sienogranitos subordinados (Barros \& Barbey 1998) que assemelham-se quimicamente aos granitos tipo A. A Suíte Pedra Branca (Feio et al. 2013) é composta por granitoides sódicos de assinatura tholeíitica, que apresentam idades U-Pb de 2.765 \pm 39 Ma (Sardinha et al. 2004) e $2.750 \pm 5 \mathrm{Ma}$ (Feio et al. 2013). O Granito Planalto tem caráter alcalino, metaluminoso a fracamente peraluminoso, com características semelhantes a dos granitos tipo A e idade de $2747 \pm 2$ Ma interpretada como idade de cristalização (Huhn et al. 1999a). O Granito Serra do Rabo também apresenta assinatura alcalina metaluminosa, similar à dos granitos do tipo $\mathrm{A}, \mathrm{e}$ idade de $2.743 \pm 1,6 \mathrm{Ma}$ (Sardinha et al. 2001) interpretada como de sua colocação. O Diorito Cristalino inclui dioritos, quartzo-dioritos, microquartzo dioritos e microtonalitos de idade de Dissertação de Mestrado - IG-USP - Soraya Damasceno Sousa - 2014 
$2.738 \pm 6$ Ma (Hunh et al. 1999a). A Suíte Plaquê é representada por diversos corpos lenticulares, orientados predominantemente segundo E-W (Araújo \& Maia (1991) que apresentaram idades de $2.727 \pm 29 \mathrm{Ma}($ Avelar 1996) e $2.736 \pm 24 \mathrm{Ma}$ (Avelar et al. 1999). O Granito Igarapé Gelado apresenta natureza cálcio-alcalina e idade de $2.731 \pm 26$ Ma que foi considerada como idade mínima de cristalização (Barbosa 2004). O Granito Velho Salobo (Lindenmayer 1990), aflora nos domínios do depósito de cobre do Salobo e forneceu idade de $2.573 \pm 2$ Ma (Machado et al. 1991).

O Complexo Máfico-ultramáfico Luanga (Jorge João et al. 1982) inclui corpos ígneos acamadados, caracterizados como: (i) zona ultramáfica consiste predominante de dunitos (olivina e cromita cumulados), com diferentes intensidades de serpentinização; (ii) zona de transição é marcada pela presença de harzburgitos (olivina cumulado com ortopiroxênio intercumulus), ortopiroxenitos (ortopiroxênio cumulado), ortopiroxenitos com plagioclásio (ortopiroxênio cumulado com plagioclásio intercumulus), cromititos (cromita cumulado) e noritos (ortopiroxênio e plagioclásio cumulados); e (iii) zona máfica que consiste de uma sequência espessa de gabros clinopiroxênio e plagioclásio cumulados), com intercalação descontínua de ortopiroxenitos e cromitito na porção intermediária. A Suíte Intrusiva Cateté (Macambira \& Vale 1997) é constituída por gabros, noritos, piroxenitos, serpentinitos e peridotitos (2.766 $\pm 6 \mathrm{Ma}$; Lafon et al. 2000). O Gabro Santa Inês é constituído por gabros porfiríticos, leucogabros, microgabros e anortositos, com texturas ofítica, subofítica e porfirítica (DOCEGEO, 1988). Segundo Araújo e Maia (1991), esta unidade é marcada por alto relevo magnético e baixos valores gamaespectrométricos.

A Formação Águas Claras (Araújo et al. 1988) representa uma cobertura siliciclástica arqueana, constituída por arenitos, siltitos, calcários e conglomerados, não metamorfisada, distribuída amplamente na porção central da estrutura sigmoidal da Serra dos Carajás (Nogueira 1995) , cuja idade mínina de deposição 3.020 Ma e 2.778 Ma foram obtidas em zircões detríticos (Mougeot et al. 1996).

Vasquez et al. (2008b) adotaram a denominação Suíte Intrusiva Carajás para os corpos graníticos (por exemplo, Central de Carajás, Cigano, Pojuca, Breves, Rio Branco) que intrudem tanto rochas do embasamento como sequências metavulcanossedimentares, granitoides e rochas sedimentares arqueanas. Caracterizam-se por uma marcante homogeneidade composicional, essencialmente monzogranítica e subordinadamente sienogranítica, semelhantes aos granitos do tipo A, apresentando idades de $1.874 \pm 2 \mathrm{Ma} \mathrm{a}$ $1.883 \pm 2$ Ma (Machado et al. 1991). 
Tabela 2: Síntese dos dados geocronológicos das unidades do Domínio Carajás.

\begin{tabular}{|c|c|c|c|c|}
\hline Unidade Estratigráfica & Método & $\begin{array}{l}\text { Material } \\
\text { Analisado } \\
\end{array}$ & Idade & Referência \\
\hline \multicolumn{5}{|l|}{ Granitos Paleoproterozóicos } \\
\hline Pojuca & $\mathrm{Pb}-\mathrm{Pb}$ & Zircão & $1.874 \pm 2 \mathrm{Ma}$ & Machado et al. 1991 \\
\hline Breves & SHRIMP & Zircão & $1.879 \pm 6 \mathrm{Ma}$ & Tallarico et al. 2005 \\
\hline Central de Carajás & $\mathrm{U}-\mathrm{Pb}$ & Zircão & $1.880 \pm 2 \mathrm{Ma}$ & Machado et al. 1991 \\
\hline Young Salobo & $\mathrm{Rb}-\mathrm{Sr}$ & Rocha total & $1.880 \pm 80 \mathrm{Ma}$ & Cordani 1981 \\
\hline Cigano & $\mathrm{U}-\mathrm{Pb}$ & Zircão & $1.883 \pm 2 \mathrm{Ma}$ & Machado et al. 1991 \\
\hline \multicolumn{5}{|l|}{ Unidades Neoarqueanos } \\
\hline Granito Old Salobo & $\mathrm{U}-\mathrm{Pb}$ & Zircão & $2.573 \pm 2 \mathrm{Ma}$ & Machado et al. 1991 \\
\hline Granito Igarapé Gelado & $\mathrm{Pb}-\mathrm{Pb}$ & Zircão & $2.731 \pm 26 \mathrm{Ma}$ & Barbosa 2004 \\
\hline Suíte Plaquê & $\mathrm{Pb}-\mathrm{Pb}$ & Zircão & $2.736 \pm 24 \mathrm{Ma}$ & Avelar et al. 1999 \\
\hline Granito Granofírico Sossego & $\mathrm{U}-\mathrm{Pb}$ & Zircão & $2.740 \pm 26 \mathrm{Ma}$ & Moreto et al. 2013 \\
\hline Granito Serra do Rabo & $\mathrm{U}-\mathrm{Pb}$ & Zircão & $2.743 \pm 1.6 \mathrm{Ma}$ & Sardinha et al. 2006 \\
\hline \multirow{3}{*}{ Suíte Planalto } & $\mathrm{Pb}-\mathrm{Pb}$ & Zircão & $2.747 \pm 2 \mathrm{Ma}$ & Huhn et al. 1999b \\
\hline & $\mathrm{Pb}-\mathrm{Pb}$ & Zircão & $2.733 \pm 2 \mathrm{Ma}$ & Feio et al. 2013b \\
\hline & $\mathrm{U}-\mathrm{Pb}$ & Zircão & $2.729 \pm 17 \mathrm{Ma}$ & Feio et al. 2013b \\
\hline Suíte Pedra Branca & $\mathrm{U}-\mathrm{Pb}$ & Zircão & $\begin{array}{l}2.762 \pm 13 \mathrm{Ma} \\
2.750 \pm 5 \mathrm{Ma}\end{array}$ & $\begin{array}{l}\text { Feio et al. 2013b } \\
\text { Feio et al., 2012b }\end{array}$ \\
\hline Granito Estrela & $\mathrm{Pb}-\mathrm{Pb}$ & Zircão & $2.763 \pm 7 \mathrm{Ma}$ & Barros et al. 2004 \\
\hline \multicolumn{5}{|l|}{ Cobertura Sedimentar } \\
\hline Formação Águas Claras & $\begin{array}{l}\text { SHRIMP } \\
\mathrm{U}-\mathrm{Pb} \\
\mathrm{U}-\mathrm{Pb}\end{array}$ & $\begin{array}{l}\text { Zircão } \\
\text { Zircão } \\
\text { Zircão }\end{array}$ & $\begin{array}{l}2.681 \pm 5 \mathrm{Ma} \\
2.645 \pm 12 \mathrm{Ma} \\
2.778 \text { a } 3020 \mathrm{Ma}\end{array}$ & $\begin{array}{l}\text { Trendall et al. } 1998 \\
\text { Dias et al. } 1996 \\
\text { Mougeot } \text { et al. } 1996 \mathrm{a}\end{array}$ \\
\hline
\end{tabular}

Rochas Máficas Intrusivas

\begin{tabular}{lllll}
\hline Diorito Cristalino & $\mathrm{Pb}-\mathrm{Pb}$ & Zircão & $2.738 \pm 6 \mathrm{Ma}$ & Huhn et al. 1999b \\
\hline Gabro Norito Sossego & SHRIMP & Zircão & $2.739 \pm 5.9 \mathrm{Ma}$ & Moreto et al. 2013 \\
\hline Gabro Curral & SHRIMP & Zircão & $2.739 .1 \pm 4.2 \mathrm{Ma}$ & Moreto et al. 2013 \\
\hline Associação Charnoquítica & $\mathrm{Pb}-\mathrm{Pb}$ & Zircão & $2.754 \pm 1 \mathrm{Ma}$ & Oliveira et al. 2010, \\
Ou Diopsídio Norito Pium & $\mathrm{U}-\mathrm{Pb}$ & Zircão & $2.735 \pm 5 \mathrm{Ma}$ & Feio et al. 2013b \\
Ortogranulito Chicrim- & $\mathrm{Pb}-\mathrm{Pb}$ & Zircão & $2.747 \pm 1 \mathrm{Ma}$ & Galarza et al. 2012 \\
Cateté & $\mathrm{Pb}-\mathrm{Pb}$ & Zircão & $2.732 \pm 1 \mathrm{Ma}$ & Galarza et al. 2012 \\
\hline
\end{tabular}

Greenstone Belts

\begin{tabular}{|c|c|c|c|c|}
\hline Grupo Rio Novo & $\mathrm{Pb}-\mathrm{Pb}$ & Rocha total & $2.658 \pm 213 \mathrm{Ma}$ & Reis et al. 2001a \\
\hline Grupo Igarapé Pojuca & $\begin{array}{l}\mathrm{Sm}-\mathrm{Nd} \\
\mathrm{Pb}-\mathrm{Pb} \\
\mathrm{U}-\mathrm{Pb}\end{array}$ & $\begin{array}{l}\text { Rocha total } \\
\text { Zircão } \\
\text { Zircão }\end{array}$ & $\begin{array}{l}2.719 \pm 80 \mathrm{Ma} \\
2.705 \pm 2 \mathrm{Ma} \\
2.732 \pm 5 \mathrm{Ma}\end{array}$ & $\begin{array}{l}\text { Pimentel et al. } 2003 \\
\text { Galarza \& Macambira } \\
\text { 2002b } \\
\text { Machado et al. } 1991\end{array}$ \\
\hline Grupo Grão-Pará & $\begin{array}{l}\mathrm{Pb}-\mathrm{Pb} \\
\mathrm{Pb}-\mathrm{Pb} \\
\mathrm{SHRIMP}\end{array}$ & $\begin{array}{l}\text { Zircão } \\
\text { Zircão } \\
\text { Zircão }\end{array}$ & $\begin{array}{l}2.759 \pm 2 \mathrm{Ma} \\
2.751 \pm 4 \mathrm{Ma} \\
2.760 \pm 11 \mathrm{Ma}\end{array}$ & $\begin{array}{l}\text { Machado et al. } 1991 \\
\text { Krymsky et al. } 2002 \\
\text { Trendall et al. } 1998\end{array}$ \\
\hline Grupo Salobo & $\begin{array}{l}\mathrm{U}-\mathrm{Pb} \\
\mathrm{U}-\mathrm{Pb} \\
\mathrm{U}-\mathrm{Pb} \\
\mathrm{Sm}-\mathrm{Nd}\end{array}$ & $\begin{array}{l}\text { Zircão } \\
\text { Titanita } \\
\text { Zircão } \\
\text { Rocha total }\end{array}$ & $\begin{array}{l}2.761 \pm 3 \mathrm{Ma} \\
2.497 \pm 5 \mathrm{Ma} \\
2.555 \pm 4 \mathrm{Ma} \\
2.812 \pm 98 \mathrm{Ma}\end{array}$ & $\begin{array}{l}\text { Machado et al. } 1991 \\
\text { Machado et al. } 1991 \\
\text { Machado et al. } 1991 \\
\text { Pimentel et al. } 2003\end{array}$ \\
\hline Grupo Igarapé Bahia & $\begin{array}{l}\text { SHRIMP } \\
\mathrm{Pb}-\mathrm{Pb} \\
\mathrm{U}-\mathrm{Pb}\end{array}$ & $\begin{array}{l}\text { Zircão } \\
\text { Zircão } \\
\text { Zircão }\end{array}$ & $\begin{array}{l}2.748 \pm 34 \mathrm{Ma} \\
2.745 \pm 1 \mathrm{Ma} \\
2.776 \pm 12 \mathrm{Ma}\end{array}$ & $\begin{array}{l}\text { Tallarico et al. } 2005 \\
\text { Galarza \& Macambira } \\
\text { 2002a } \\
\text { Galarza et al. } 2003\end{array}$ \\
\hline
\end{tabular}

Complexo Máfico-Ultramáficos

\begin{tabular}{lllll}
\hline Complexo Luanga & U-Pb & Zircão & $2.763 \pm 6 \mathrm{Ma}$ & Machado et al. 1991 \\
\hline Suíte Intrusiva Cateté & SHRIMP & Zircão & $2.766 \pm 6 \mathrm{Ma}$ & Lafon et al. 2000 \\
\hline \multirow{2}{*}{ Granitoides Mesoaqueanos } & & & & \\
& & & & \\
\hline \multirow{2}{*}{ Granito Serra Dourada } & U-Pb & Zircão & $2.860 \pm 22 \mathrm{Ma}$ & Moreto et al. 2011 \\
& U-Pb & Zircão & $2.831 \pm 6 \mathrm{Ma}$ & Feio et al. 2013 \\
\hline Granito Bom Jesus & SHRIMP & Zircão & $2.833 \pm 6 \mathrm{Ma}$ & Feio et al. 2013 \\
\hline
\end{tabular}


Continuação

\begin{tabular}{|c|c|c|c|c|}
\hline \multirow[b]{2}{*}{ Granito Cruzadão } & $\mathrm{U}-\mathrm{Pb}$ & Zircão & $2.845 \pm 15 \mathrm{Ma}$ & Feio et al. 2013 \\
\hline & $\mathrm{U}-\mathrm{Pb}$ & Zircão & $\begin{array}{l}2.857 \pm 8 \mathrm{Ma} \\
2.875 \pm 12 \mathrm{Ma} \\
3.053 \pm 8 \mathrm{Ma}\end{array}$ & Feio et al. 2013 \\
\hline Complexo Tonalítico & $\mathrm{U}-\mathrm{Pb}$ & Zircão & $2.850 \pm 7 \mathrm{Ma}$ & Feio et al., 2012 \\
\hline Campina Verde & $\mathrm{Pb}-\mathrm{Pb}$ & Zircão & $2.872 \pm 1 \mathrm{Ma}$ & Feio et al., 2012 \\
\hline Granodiorito Água Azul & $\mathrm{Pb}-\mathrm{Pb}$ & Zircão & $2.884 \pm 1,7 \mathrm{Ma}$ & Sousa et al., 2010 \\
\hline Granodiorito Água Limpa & $\mathrm{Pb}-\mathrm{Pb}$ & Zircão & $2.879 \pm 1,3 \mathrm{Ma}$ & Gabriel et al., 2010 \\
\hline Trondhjemito Rio Verde & $\mathrm{U}-\mathrm{Pb}$ & Zircão & $2.923 \pm 15 \mathrm{Ma}$ & Feio et al., 2012 \\
\hline Granito Canaã dos Carajás & $\mathrm{U}-\mathrm{Pb}$ & Zircão & $2.959 \pm 6 \mathrm{Ma}$ & Feio et al., 2012 \\
\hline Tonalito Bacaba & $\begin{array}{l}\mathrm{U}-\mathrm{Pb} \\
\mathrm{U}-\mathrm{Pb}\end{array}$ & $\begin{array}{l}\text { Zircão } \\
\text { Zircão }\end{array}$ & $\begin{array}{l}3.0012 \pm 3.6 \mathrm{Ma} \\
3.0046 \pm 5.9 \mathrm{Ma}\end{array}$ & $\begin{array}{l}\text { Moreto et al., } 2011 \\
\text { Moreto et al., } 2011\end{array}$ \\
\hline \multicolumn{5}{|l|}{ Rochas do Embasamento } \\
\hline Complexo Xingu & $\begin{array}{l}\mathrm{U}-\mathrm{Pb} \\
\mathrm{U}-\mathrm{Pb}\end{array}$ & $\begin{array}{l}\text { Zircão } \\
\text { Zircão }\end{array}$ & $\begin{array}{l}2.859 \pm 2 \mathrm{Ma} \\
2.974 \pm 15 \mathrm{Ma}\end{array}$ & $\begin{array}{l}\text { Machado et al., } 1991 \\
\text { Machado et al., } 1991\end{array}$ \\
\hline $\begin{array}{l}\text { Ortogranulito Chicrim- } \\
\text { Cateté }\end{array}$ & $\begin{array}{l}\text { SHRIMP } \\
\text { SHRIMP }\end{array}$ & $\begin{array}{l}\text { Zircão } \\
\text { Zircão }\end{array}$ & $\begin{array}{l}3.002 \pm 14 \mathrm{Ma} \\
2.859 \pm 9 \mathrm{Ma}\end{array}$ & $\begin{array}{l}\text { Pidgeon et al., } 2000 \\
\text { Pidgeon } \text { et al.,2000 }\end{array}$ \\
\hline
\end{tabular}




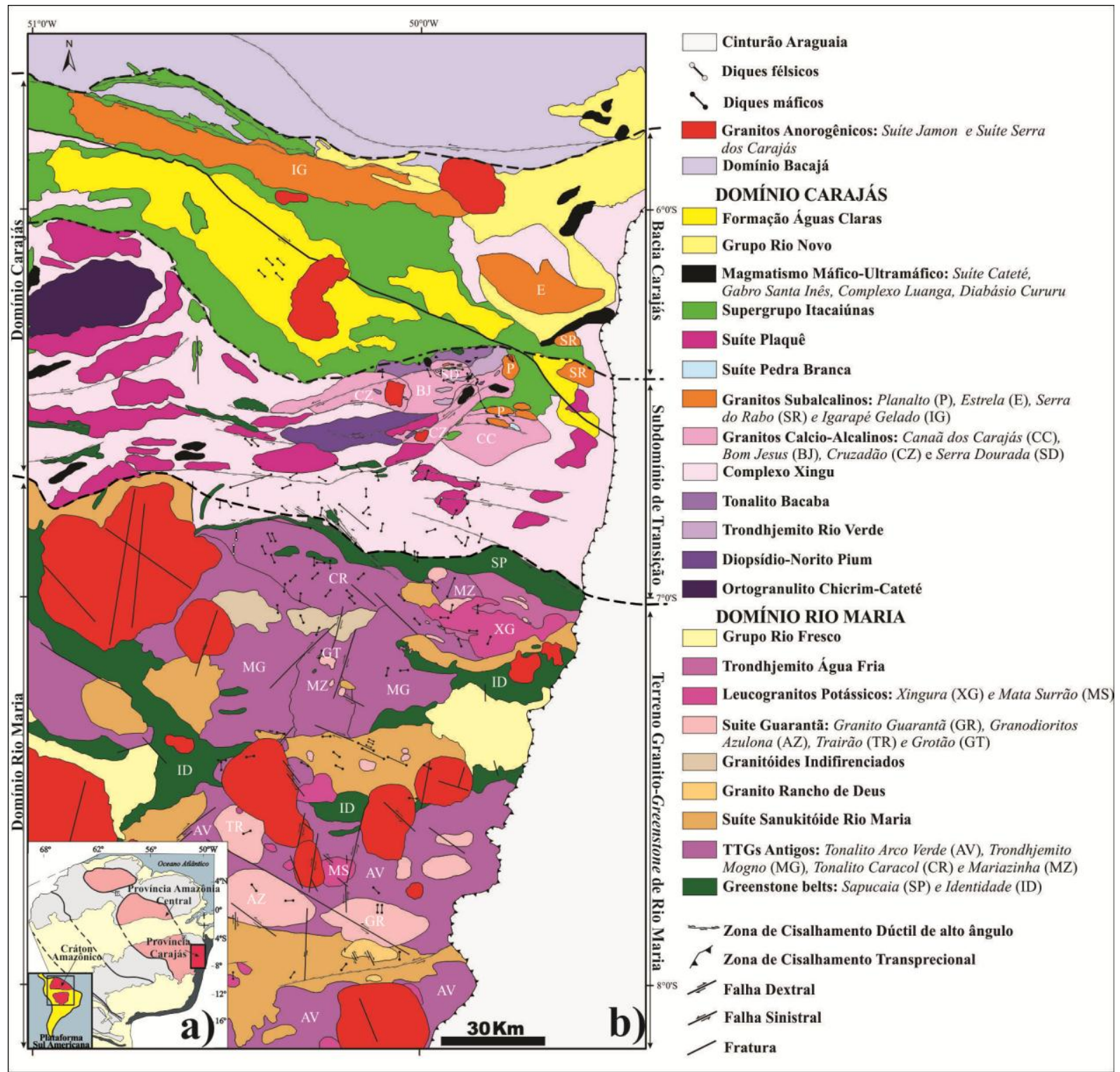

Figura 10. a) Localização da Província Carajás no Cráton Amazônico, modificado de Tassinari \& Macambira (1999); b) Mapa geológico da Província Carajás, modificado de Vasquez et al. (2008b), Almeida (2010) e Feio et al. (2012). 


\section{O GREENSTONE BELT SAPUCAIA NA REGIÃO DE ÁGUA AZUL DO NORTE, PROVÍNCIA CARAJÁS}

\subsection{TRABALHOS ANTERIORES}

Os litotipos do Grupo Sapucaia foram estudados pela primeira vez por Cordeiro (1982) e Hirata et al. (1982), que descreveram textura spinifex em rochas ultramáficas nas proximidades do Igarapé Sapucaia. Posteriormente, trabalhos de mapeamento foram feitos nessa região pela DOCEGEO (1988), contudo, o Grupo Sapuacia foi formalizado apenas por Araújo \& Maia (1991), a partir do mapeamento da Folha Carajás (SB-22-Z), realizado pela CPRM. As rochas nas proximidades da cidade de Sapucaia foram descritas como parte de uma sequência metavulcanossedimentar com ocorrência no Domínio Rio Maria.

O greenstone belt do Grupo Sapucaia, segundo o mapa proposto mais recentemente (Vasquez et al. 2008b, Almeida 2010 e Feio 2011), ocorre no limite entre os domínios Rio Maria e Carajás (figura 07). As rochas deste grupo, segundo Araújo \& Maia (1991), ocorrem em uma faixa alongada com cerca de $120 \mathrm{~km}$ de extensão e 1 a $10 \mathrm{~km}$ de largura. Também ocorrem em segmentos menores, orientados ao longo da direção geral WNW-ESE, por vezes associados aos gnaisses e migmatitos do Complexo Xingu (Oliveira et al. 2010) ou como pequenas lentes imbricadas tectonicamente ao Granito Serra Dourada na parte sul do Domínio Carajás, no Subdomínio de Transição ou Domínio Canaã dos Carajás (Moreto et al. 2013b). Apesar dessas pequenas ocorrências no Domínio Carajás (Oliveira et al. 2010, Feio 2011), admite-se que essa unidade faça parte da história evolutiva do Domínio Rio Maria embora ainda não existam dados geocronológicos que permitam tal afirmação.

Oliveira et al. (1995) apresentou um maior detalhamento das sequências pertencentes ao Grupo Sapucaia, dividindo-as em três unidades principais: a) Unidade básica-ultrabásica diferenciada (dunitos, peridotitos, piroxenitos e gabros); b) Unidade metavulcânica intermediária a básica (milonitos, basaltos e andesitos basálticos); e c) unidade metavulcânica ácida, que inclui metassedimentos químicos e pelíticos. Estas unidades encontram-se recortadas por diques retilíneos de diabásio e corpos irregulares (amebóides) de natureza gabroide que mostram contornos milonitizados e núcleos destituídos de deformação. Estes autores também definiram a Zona de Cisalhamento Diadema, de direção geral WNW-ESE, cuja evolução teria sido responsável pela mineralização aurífera do depósito homônimo.

Uma síntese e apresentação de novos dados do contexto geológico da área foi realizado pela CPRM em 2008 (Vasquez et al. 2008b), porém, pequenas alterações foram propostas em relação aos trabalhos anteriores. As rochas da sequência metavulcanossedimentar do 
greenstone belt do Grupo Sapucaia encontram-se em contato com as rochas da série tonalítica-trondhjemítica-granodiorítica (TTG), atribuídas ao Complexo Xingu.

Novos trabalhos de mapeamento e caracterização petrográfica nos corpos de greenstones belts do Grupo Sapucaia na região da Vila Nova Canadá foram feitos por Faresin (2010), Santos (2010), Sousa (2010) e sintetizados por Oliveira et al. (2010).

De acordo com Faresin et al. (2010), cuja área de estudo se sobrepõe à parte noroeste da área dessa pesquisa (Fig. 01), a sequência metavulcanossedimentar é representada por rochas ultramáficas metamorfisadas sob condições de fácies xisto verde a anfibolito, que incluem metaperidotito, talco xisto e rochas de composição gabroica. De acordo com Santos et al. (2010), o mapeamento e caracterização petrográfica de rochas da sequência greenstone na região de Nova Canadá, município de Canaã dos Carajás, ao norte da área de estudo desta pesquisa (Fig. 01), permitiram a individualização de rochas anfibolíticas e metassedimentares. $\mathrm{Na}$ região de Água Azul do Norte, próximo da parte noroeste desta área (Fig. 01), foi caracterizada por Sousa (2010) uma sequência de rochas metavulcanossedimentares com paragênese mineral indicando metamorfismo na fácies dos xistos verdes formada por metaultramafitos na base, composto por serpentina-tremolita xistos, seguida pela sequência metassedimentar composta por quartzito e muscovita xisto no topo.

Em relação ao magmatismo máfico na região de Nova Canadá, Marangoanha \& Oliveira (2013), descreveram anfibolitos que foram metamorfisados sob fácies xisto verde a anfibolito, com forte foliação nas proximidades das zonas de cisalhamento, constituindo corpos isotrópicos longe dessas zonas, constituídos por plagioclásio, hornblenda, minerais opacos, titanita e biotita. Diques de diabásio constituídos essencialmente por plagioclásio, piroxênio (orto- e clinopiroxênio), anfibólio e minerais opacos, não foliados, com texturas intergranular, ofítica e subofítica também foram descritos.

Alguns trabalhos de caracterização geológica, geoquímica e geocronológica foram feitos na região dos domínios Carajás e Rio Maria (Vasquez et al. 2008b, Almeida 2010, Feio 2011), porém, predominantemente voltados para a associação granito-gnáissico e migmatítica mesoarqueana. 


\subsection{CONTEXTO GEOLÓGICO DA ÁREA DE ÁGUA AZUL DO NORTE}

As rochas aflorantes na área de estudo compreendem granitoides, sequências metavulcanossedimentares e diques de composição gabroica. Essas rochas estão referidas no trabalho de Araújo \& Maia (1991) e Vasquez et al. (2008b) como pertencentes, respectivamente, ao Complexo Xingu e ao Grupo Sapucaia.

Os afloramentos constituem poucas exposições com significativa continuidade lateral e vertical, o que dificulta a interpretação da evolução estratigráfica da área. Esses afloramentos, em geral, são pouco expressivos, geralmente ocorrendo na forma de blocos in situ e rolados, e em pequenos cortes de estrada, nos quais os litotipos apresentam-se bastante intemperizados (Fig. 11-1 a 4).

O Grupo Sapucaia corresponde a uma faixa alongada e lenticularizada, com direção preferencial E-W, ocorrendo geralmente em forma de morros e pequenas serras. É constituído, na área de estudo, por unidade metaultrámafica com predomínio de Mg-cloritatremolita xistos, com talco xistos, serpentinitos com relíquias de olivina e clorititos (Fig. 11-2 a 11-4) subordinados, além de unidade máfica composta por hornblenda anfibolito e unidade metassedimentar com (granada)-muscovita-biotita xistos.

A ocorrência de litotipos da sequência metavulcanossedimentar Sapucaia apresenta forte relação espacial com zonas de cisalhamento, provavelmente regionais. Os contatos predominantemente tectônicos entre as rochas metavulcanossedimentares e os granitoides são marcados por intensa milonitização das rochas e pelo alojamento de espessos veios de quartzo (> 10 m) (Fig. 12-1,6 e 7). Os corpos plutônicos, com orientação preferencial NW-SE e E-W, seguindo a estruturação regional (Fig. 12-1), ocorrem em toda extensão da área mapeada, principalmente sob a forma de lagedos e blocos rolados.

Nos litotipos do greenstone, além da foliação milonítica (direção E-W com inflexões para NW-SE e NE-SW), a xistosidade (Sn) representa a estrutura planar penetrativa predominante (Fig. 12-4). Caracteriza-se por apresentar mergulhos para sul, variando entre $25^{\circ}$ e $75^{\circ}$ e, subordinadamente, para norte. Apresenta-se comumente crenulada, com a foliação $S_{n+1}$ com suaves inflexões para NE-SW e NW-SE (Fig. 12-8). As dobras ocorrem em zonas restritas da área, sendo visualizadas em escala de afloramento com dimensões centimétricas. Quanto à sua geometria, as dobras observadas são em sua grande maioria abertas e simétricas, apresentam-se com o ângulo inter-flanco fechado, outros suaves e, localmente, chegam a ser assimétricas. São no geral harmônicas e estão associadas a bandas de cisalhamento (Fig. 12-5). 
Os granitoides correspondem principalmente a biotita gnaisses de composição granodiorítica com bandamento composicional dobrado e, localmente, transposto por foliação milonítica (Fig. 12-2 e 3), migmatitos com evidência de fusão in situ e leucogranitos de coloração cinza-esbranquiçada e aspecto anisotrópico variável, evidenciado principalmente pelo alinhamento dos minerais máficos.

Os corpos máficos são expressivos na área e cortam indiscriminadamente os litotipos aflorantes, com orientações variadas (NE-SW, NW-SE e N-S). Correspondem a corpos com morfologia predominantemente tabular com dimensões métricas alcançando grandes extensões, chegando por vezes a exibir continuidade por cerca de 1 a $2 \mathrm{~km}$, com afloramentos dispostos principalmente na forma de blocos in situ e blocos rolados. As composições dessas rochas variam de gabroicas a quartzo-gabroicas, subordinadamente.

As zonas de cisalhamento identificadas são de caráter dúctil, caracterizadas pela presença de foliação milonítica anastomasosada, pares S-C, porfiroclastos rotacionados e ribbons de quartzo. Dados de campo integrados às informações das estruturas fotointerpretadas obtidas a partir de imagens de sensores remotos podem fornecer a disposição espacial destas estruturas. Ocorrem principalmente nas rochas adjacentes aos limites da faixa de rochas ultramáficas pertencentes ao greenstone belt, onde as rochas ocorrem fortemente milonitizadas ao longo de um trend preferencial $\mathrm{E}-\mathrm{W}$, com caimento em média de $65^{\circ}$ para sul.

As zonas de cisalhamento marcam o contato entre os corpos granitoides e a faixa supracrustal. A trama dúctil desenvolvida na área reflete uma história cinemática complexa devido à ausência de um padrão cinemático dominante para o cisalhamento que afetou estas rochas. 

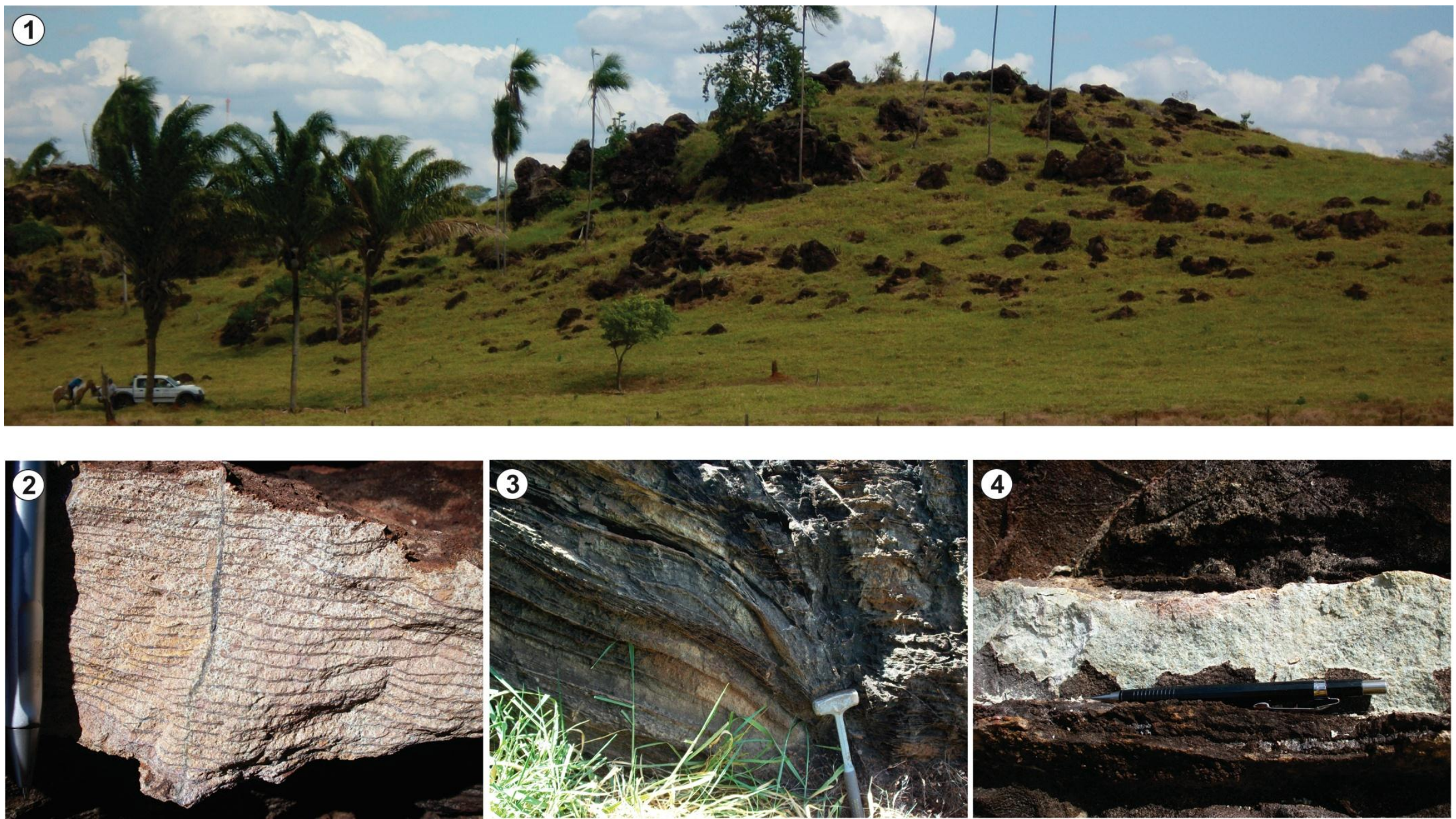

Figura 11. 1) Modo de ocorrência das rochas metaultramáficas em blocos in situ e rolados; 2) rocha metaultramáfica intensamente intemperizada com relíquia de possíveis pseudomorfos de cristais de olivina e foliação metamórfica; 3) foliação milonítica em rocha metaultramáfica, 4) variedade litológica das rochas ultramáficas pertencentes ao Grupo Sapucaia, representada por Mg-clorita-tremolita xistos com porfiroblastos idiomórficos de magnetita. 

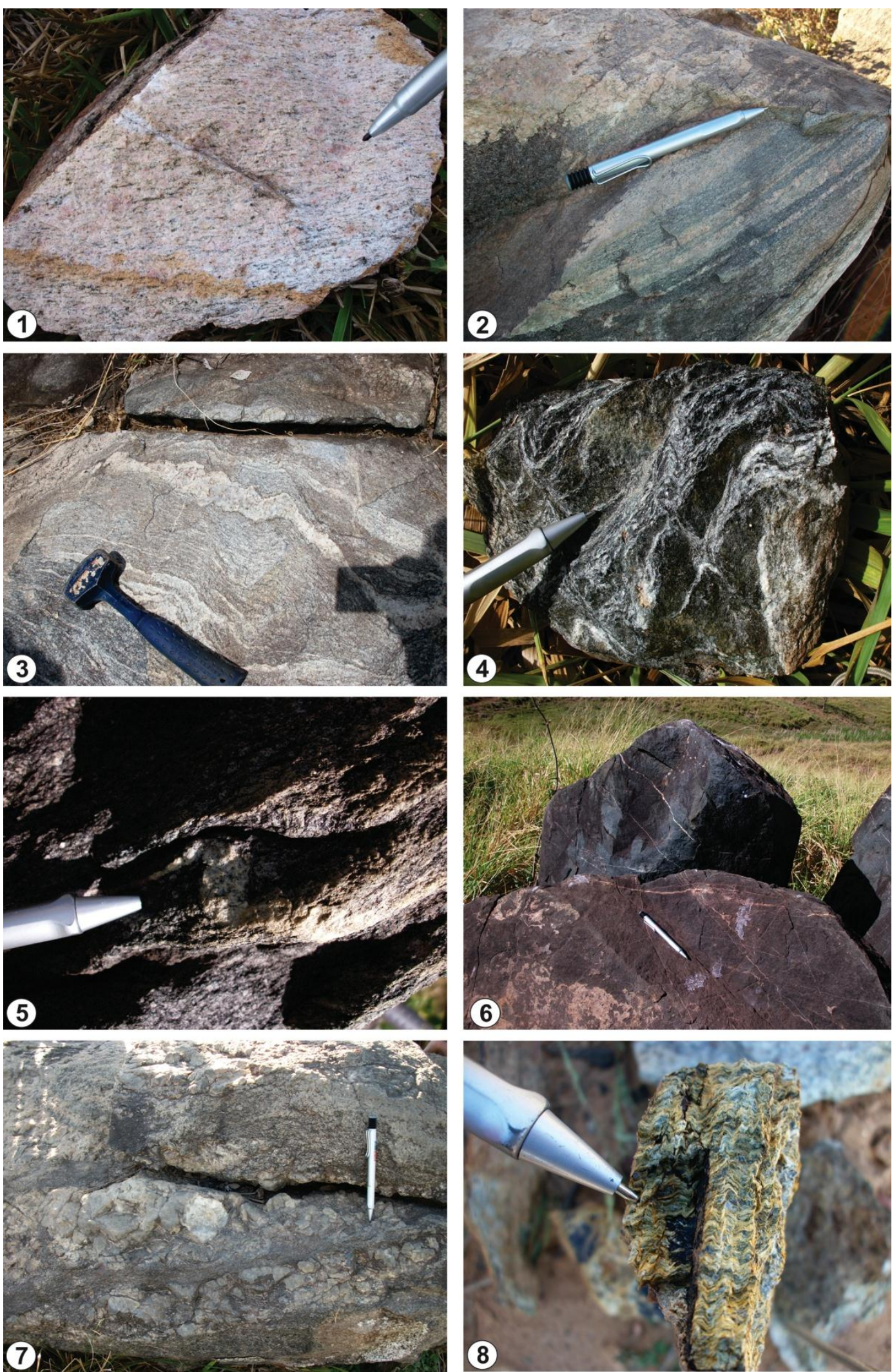

Figura 12. Feiçoes estruturais caracterizadas na área de estudo: 1) foliação milonítica em biotita granodiorito, com presença de porfiroclastos de quartzo e plagioclásio; 2) bandamento composicional representado por bandas quartzo-feldspática e por bandas de minerais máficos em gnaisses; 3) dobras assimétricas em migmatito (metatexito estromático); 4) foliação milonítica em zona de cisalhamento, no contato entre os granitoides e as rochas do Grupo Sapucaia; 5) foliação milonítica e dobramento de veios de quartzo em biotita granodiorito cisalhado; 6) fraturas e vênulas preenchidas com quartzo em dique de rocha máfica; 7) injeções pegmatíticas em biotita tonalito; 8) clivagem de crenulação bem desenvolvida nas rochas metaultramáficas (tremolita-Mg-clorita xistos). 


\subsection{CARACTERIZAÇÃO GEOLÓGICA E PETROGRÁFICA}

Nas proximidades de Água Azul do Norte, a sequência metavulcanosedimentar inclui litotipos predominantemente metaultramáficos, com metabasitos e unidades metapelíticas subordinadas (Fig. 13). As rochas metaultramáficas são mais comumente representadas por variedades de clorita-anfibólio xistos, seguidos por clorititos, serpentinitos e talco xistos, além de metatufitos máficos subordinados. Nas rochas metaultramáficas, em algumas amostras, ainda é possível observar restos de olivina com tramas sugestivas de re-equilíbrio metamórfico e relictos de texturas cumuláticas. Em geral, observa-se apenas o produto da destruição total da mineralogia e texturas primárias.

Além de rochas metaultramáficas, litotipos petrográficos subordinados, como anfibolitos diversos e rochas metassedimentares, tais como (granada)-muscovita-biotita xisto são reconhecidos.

Corpos com orientações variadas (NE-SW, NW-SE e N-S) de composição básica, caráter isotrópico e coloração cinza-escuro também foram encontrados. Apresentam granulação fina a média. Texturalmente apresentam aspecto equigranular idiomórfico, caráter isotrópico e arranjo subofítico dos minerais. 


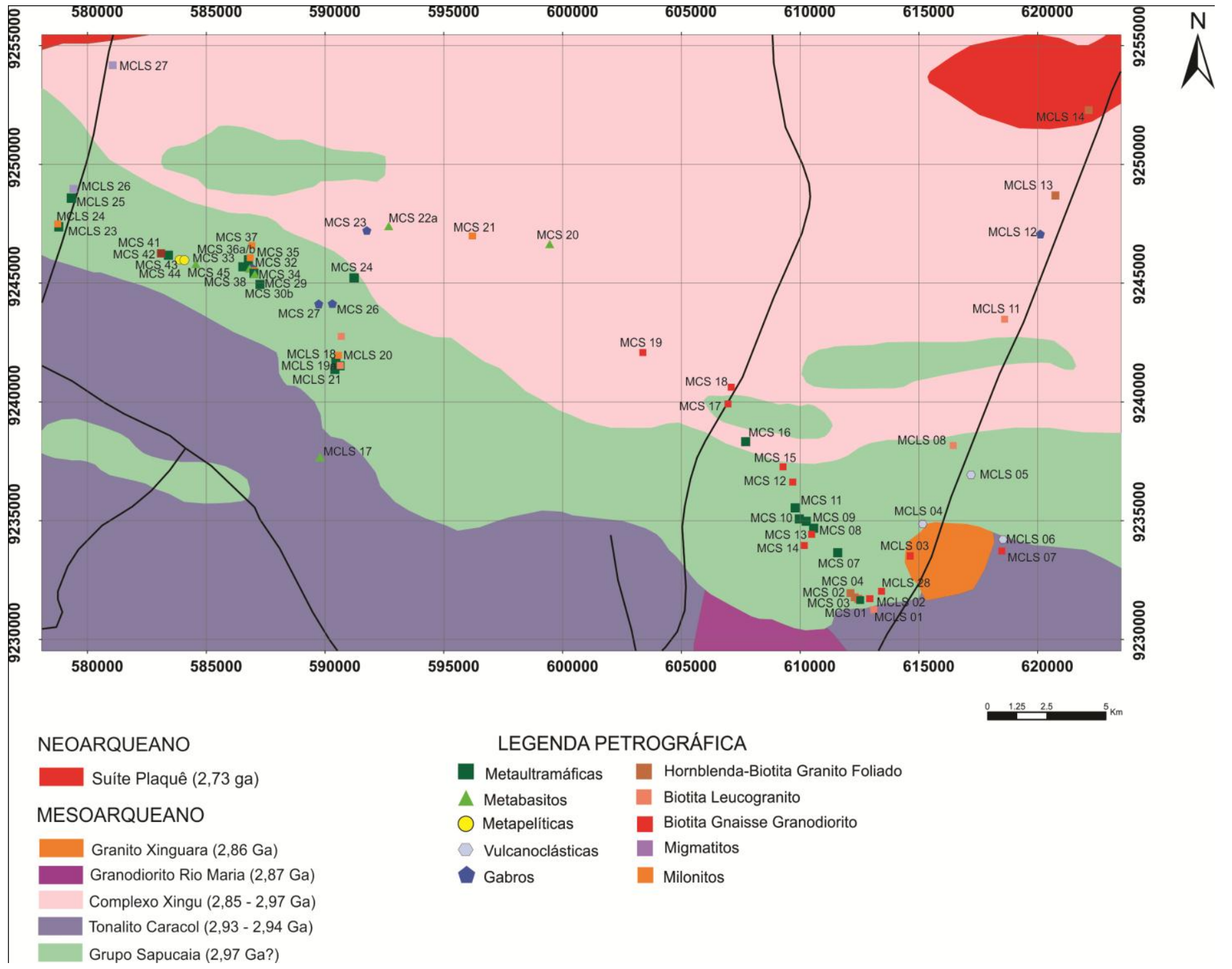

Figura 13. Mapa de localização dos pontos amostrados sobrepostos ao mapa geológico da região de Água Azul do Norte de Araújo \& Maia (1991). 


\subsubsection{Unidade Metaultramáfica}

Os serpentinitos correspondem a litotipo intensamente intemperizado, de cor ocre, localmente com muitas cavidades devido à completa destruição dos minerais metamórficos. As suas partes mais preservadas são representadas por rochas comumente foliadas (Fig. 14-1) homogêneas, de coloração verde claro e de granulação fina (Fig. 14-2). Apresentam comumente textura em rede.

Nos serpentinitos, a quantidade de serpentina supera $50 \%$ e normalmente apresentam quantidades variáveis de olivina (Fig. 14-3), clorita, magnetita e calcedônia. A serpentina, submilimétrica (dimensões inferiores a 0,6 mm), preenche os canais da textura em rede, envolvendo os pseudomorfos de olivina (Fig. 14-4 a 14-7). Análises por difratometria de raios $\mathrm{X}$ de algumas amostras de serpentinitos mostram a predominância de lizardita $\left[\mathrm{Mg}_{3} \mathrm{Si}_{2} \mathrm{O}_{5}(\mathrm{OH})_{4}\right]$.

Apesar do metamorfismo, é possível reconhecer nos serpentinitos vestígios de texturas pré-existentes, tal como texturas cumuláticas da rocha original. Cristais de olivina (forsterita) e/ou pseudomorfos de olivina de dimensões milimétricas até $4 \mathrm{~mm}$ foram intensamente intemperizados e substituídos por limonita.

A clorita, normalmente não ultrapassa 5\%, apresenta dimensões submilimétricas a milimétricas, com fraco pleocroísmo e ocorre orientada segundo a foliação, localmente apresentando-se intercrescida com a serpentina. Análises de difratometria de raios $\mathrm{X}$ (amostra MCLS 18a) indicou que a clorita presente nesse litotipo é representada pela variedade nimita $\left[(\mathrm{Ni}, \mathrm{Mg}, \mathrm{Fe}) 5 \mathrm{Al}\left(\mathrm{Si}_{3} \mathrm{Al}\right) \mathrm{O}_{10}(\mathrm{OH})_{8}\right]$, que incorpa níquel em sua estrutura. Magnetita varia de traços a 4\%, e ocorre em cristais submilimétricos a porfiroblásticos (mais raros), anédricos, apresentando localmente bordas dendríticas que podem ou não estar orientadas e associados aos cristais de olivina variavelmente serpentinizados (Fig. 14-8).

A calcedônia preenche os canais da textura em rede e ocorre no plano da foliação disjuntiva, localmente espaçada, podendo variar de 5 - 20\%. Entretanto, em litotipos intensamente intemperizados, nos quais a olivina foi completamente destruída e substituída por limonita, a calcedônia é mais comum. Vênulas orientadas preenchidas por calcedônia com textura de preenchimento de espaços abertos sugere silicificação tardia em condições essencialmente rúpteis. 

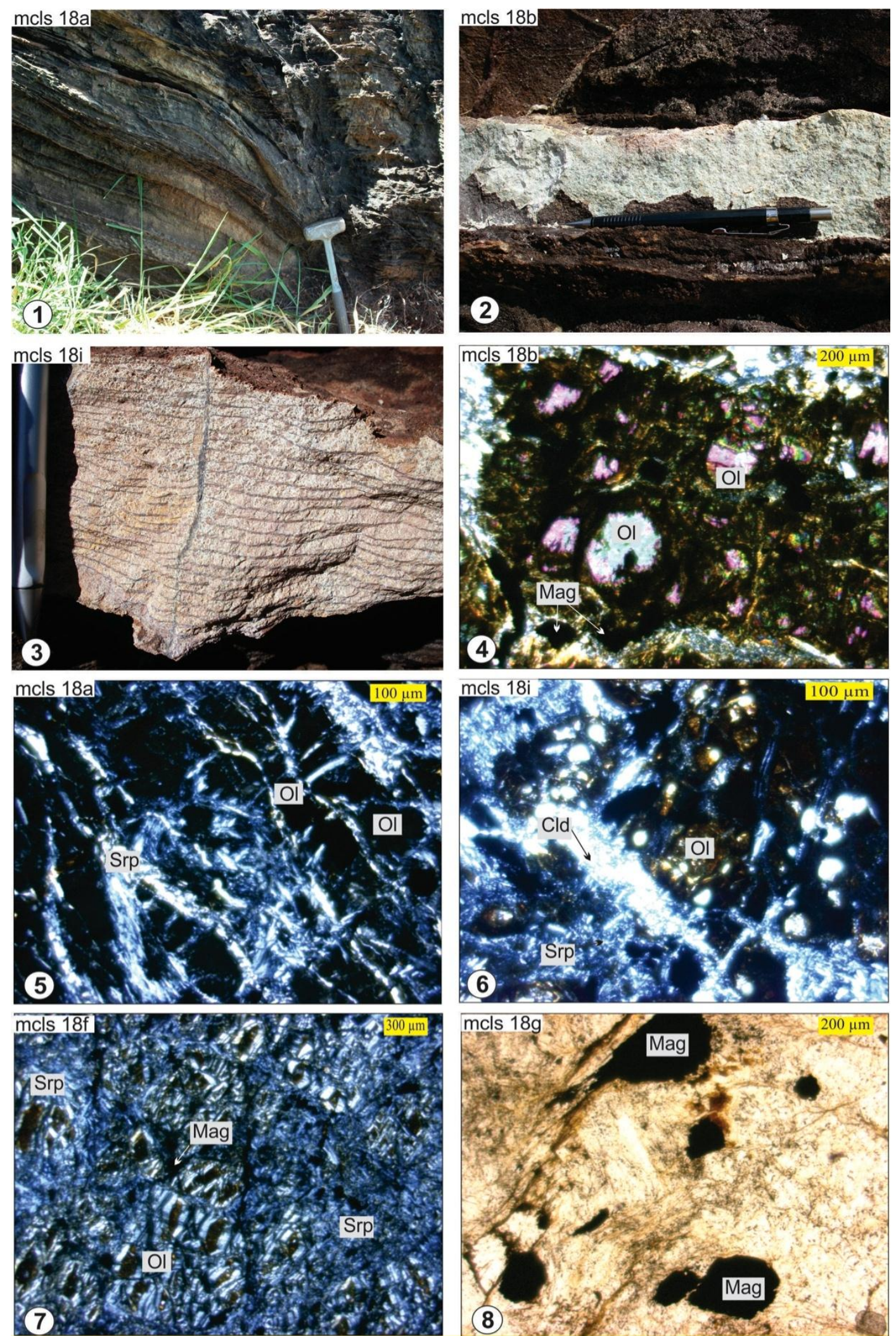

Figura 14. (1) Modo de ocorrência dos serpentinitos foliados; (2) Detalhe da amostra de serpentinito, mostrando a granulação fina dos litotipos mais preservados; (3) amostra de serpentinito com pseudomorfos de olivina e calcedônia ao longo de planos de foliação, fraturas e descontinuidades; (4) detalhe dos cristais parcialmente preservados de olivina, e sua substituição por limonita (fotomicrografia em luz transmitida; polarizadores cruzados); (5), (6) e (7) textura em rede, na qual os canais são preenchidos por serpentina e calcedônia, com alguns cristais de magnetita associados (fotomicrografia em luz transmitida; polarizadores cruzados); e (8) detalhe dos cristais de magnetita subeuhedrais associados com lizardita (fotomicrografia em luz transmitida; polarizadores descruzados). Abreviações: $\mathrm{Cld}=$ Calcedônia; $\mathrm{Mag}=$ magnetita; $\mathrm{Ol}=$ olivina; $\mathrm{Srp}=$ serpentina. 
Os talco xistos são rochas de coloração verde-acinzentada, granulação fina e xistosidade (Sn) bem desenvolvida (Fig. 15-1). Apresentam clivagem de crenulação $(\mathrm{Sn}+1)$ com dobras do tipo kinks bands associadas (Fig. 15-2), que localmente transpõe a Sn (Fig 153 e 15-4). Mineralogicamente são compostas por talco (70 - 80\%), Mg-clorita (10 - 20\%) e magnetita $(10-15 \%)$.

O talco ocorre em cristais milimétricos a submilimétricos $(<0,2 \mathrm{~mm})$, orientados no plano das foliações $\mathrm{Sn}$ e Sn+1 (Fig. 15-3 e 15-4). Comumente, a clorita apresenta cor de interferência verde acinzentada, típica do clinocloro, e granulação fina $(<0,2 \mathrm{~mm})$, orientando-se juntamente aos cristais de talco ao longo da Sn. Os cristais hipidiomórficos e finos de magnetita alinham-se preferencialmente no plano da clivagem de crenulação $(\mathrm{Sn}+1$; Fig. 15-5 e 15-6), embora também possam ser observados em associação com talco na foliação $\mathrm{Sn}$.

Os (Mg-clorita)-anfibólio xistos incluem diversos litotipos com nomenclaturas diferentes, devido à variável presença de orto e clinoanfibólios e suas porcentagens.

Os antofilita-clorita-tremolita xistos ocorrem em blocos (Fig. 16-1) e possuem coloração verde, granulação fina (Fig. 16-2) e textura porfiroblástica. Mineralogicamente são rochas compostas por Mg-clorita (20 - 25\%), antofilita (10 - 20\%), tremolita (40 - 45\%), talco (1 - 5\%) e carbonato (1 - 5\%), além de magnetita, ilmenita e pirrotita (5\%). Raramente foi observada também a ocorrência de ferri-magnésio hornblenda nesse litotipo. Apresentam xistosidade $(\mathrm{Sn})$ e planos de crenulação $(\mathrm{Sn}+1)$ bem desenvolvidos, marcados pela orientação preferencial dos prismas de tremolita, antofilita e pelos cristais de clorita.

A tremolita ocorre em finos cristais orientados segundo a $\mathrm{Sn}$ e, principalmente, como porfiroblastos (Fig. 17-1 a 17-4), que por vezes, apresentam sombra de pressão preenchidas com clorita magnesiana, indicando sua blastese pré-cinemática em relação à foliação Sn. A antofilita (Fig. 17-1 e 17-2), um ortoanfibólio incolor, normalmente ocorre com hábito prismático e textura porfiroblástica. Comumente ocorre nas bordas dos porfiroblastos de tremolita (Fig. 18-1 e Fig. 18-2), indicando sua substituição, e não necessariamente alinhados ao plano da foliação Sn. Sua caracterização foi confirmada a partir de análises de difração de raios-X e de EDS acoplado a Microscopia Eletrônica de Varredura (MEV). 

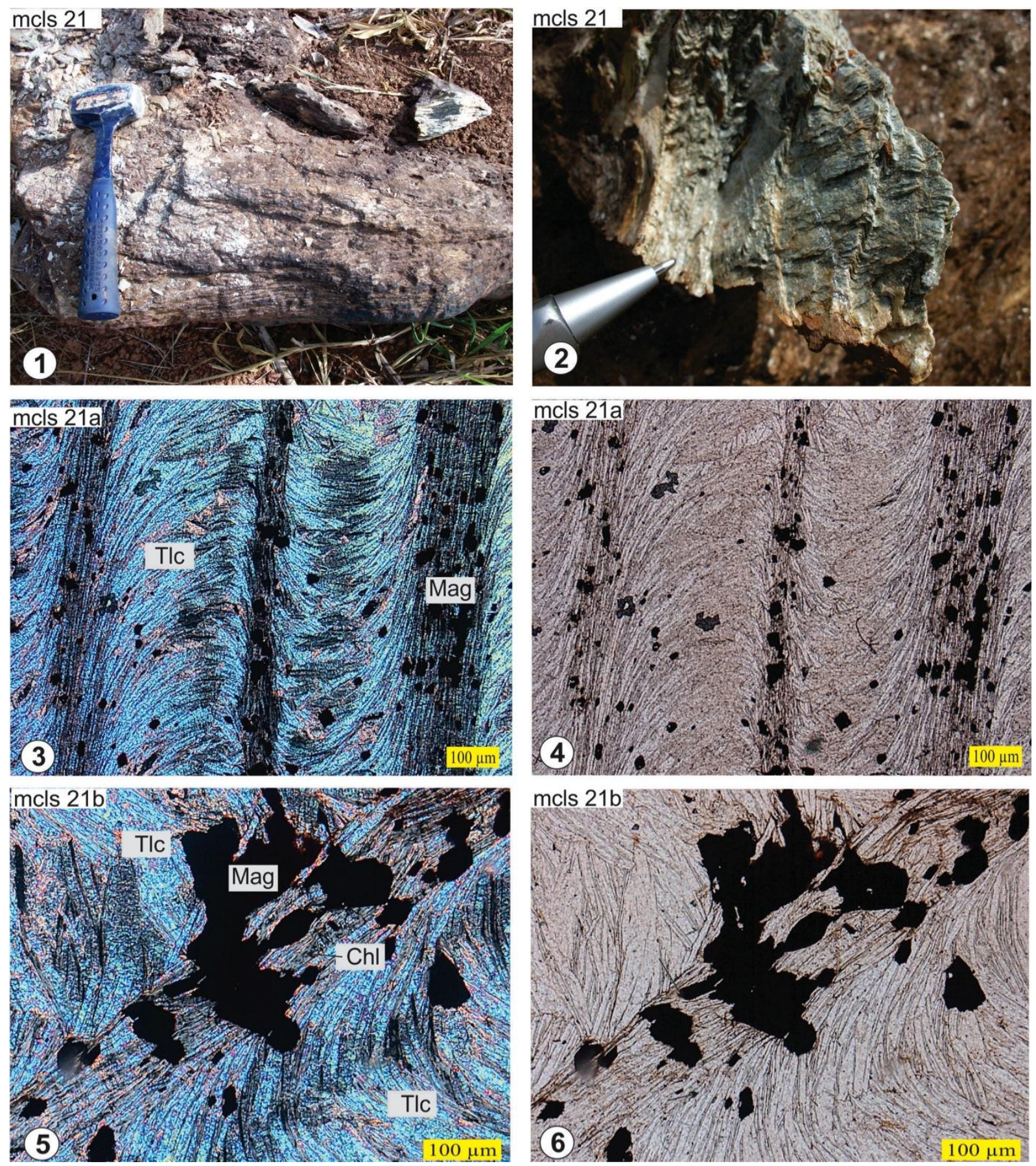

Figura 15. (1) Modo de ocorrência, geralmente em blocos rolados ou pequenos lajedos, do talco xisto; (2) detalhe da amostra de talco xisto com clivagem de crenulação bem desenvolvida; (3) talco xisto crenulado com foliação Sn localmente transposta pela foliação $\mathrm{Sn+1}$, ao longo da qual orientam-se cristais de magnetita (fotomicrografia em luz transmitida, polarizadores cruzados); (4) Idem com polarizadores descruzados; (5) talco xisto com magnetita alinhada no plano da clivagem de crenulação (fotomicrografia em luz transmitida, polarizadores cruzados); (6) Idem com polarizadores descruzados. Abreviações: $\mathrm{Chl}=$ clorita; $\mathrm{Mag}$ = magnetita; Tlc $=$ talco. 
Os cristais de clorita são submilimétricos $(<0,6 \mathrm{~mm})$, pouco pleocróicos (incolores a verde claros) e possuem cor de interferência verde acinzentada, ocorrendo no plano da foliação Sn. Análise de EDS indicou composição de clinocloro (Fig. 18-1) para a clorita. O talco geralmente é observado nas bordas dos porfiroblastos de tremolita, substituindo-os (Fig. 17-3). O mineral carbonático presente nesse litotipo é bastante comum (Fig. 18-3), todavia não foi possível identificação precisa da sua composição a partir de análises de difração de raios-X, porém, pode se tratar de magnesita, compatível com rochas ricas em magnésio e comum em rochas semelhantes de outras sequências vulcanossedimentar. Os minerais opacos localizam-se preferencialmente nas bordas dos anfibólios, substituindo-os ao longo dos planos de clivagem e fraturas.
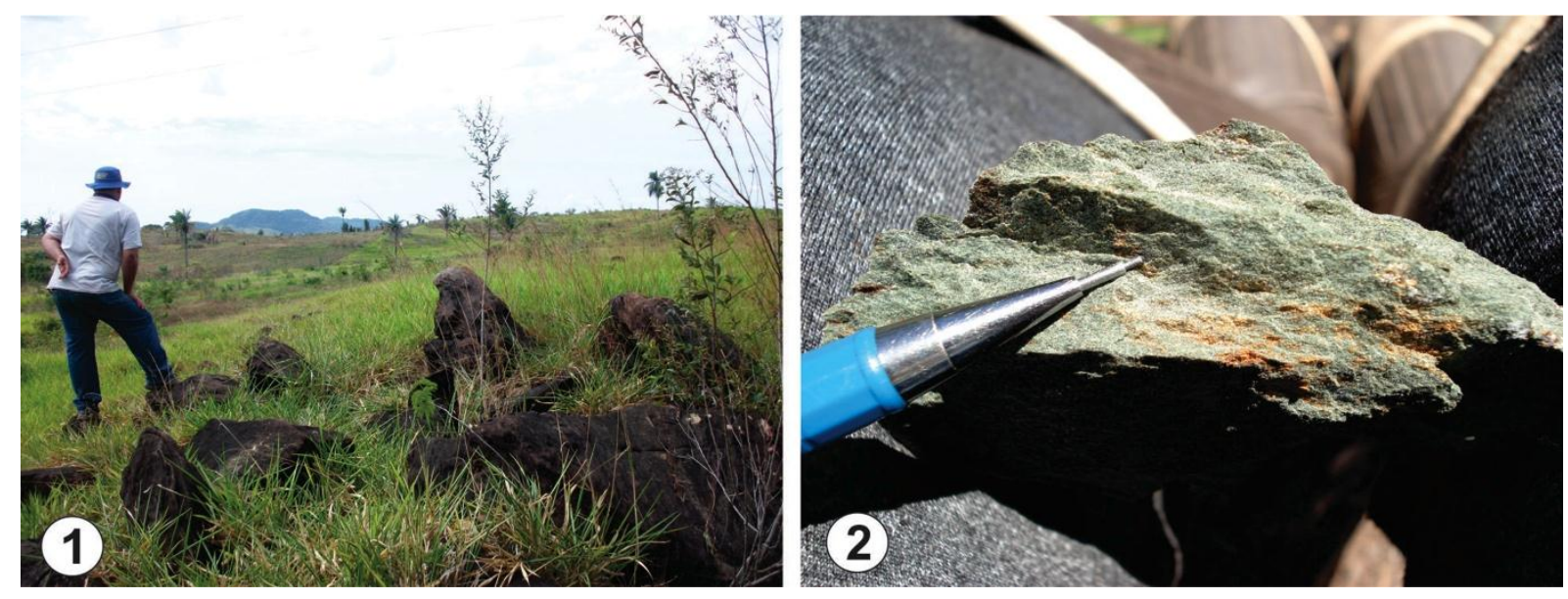

Figura 16. (1) modo de ocorrência em blocos rolados dos antofilita-clorita-tremolita xistos; e (2) detalhe macroscópico dos antofilita-clorita-tremolita xistos, mostrando sua textura fina e foliação bem desenvolvida. 

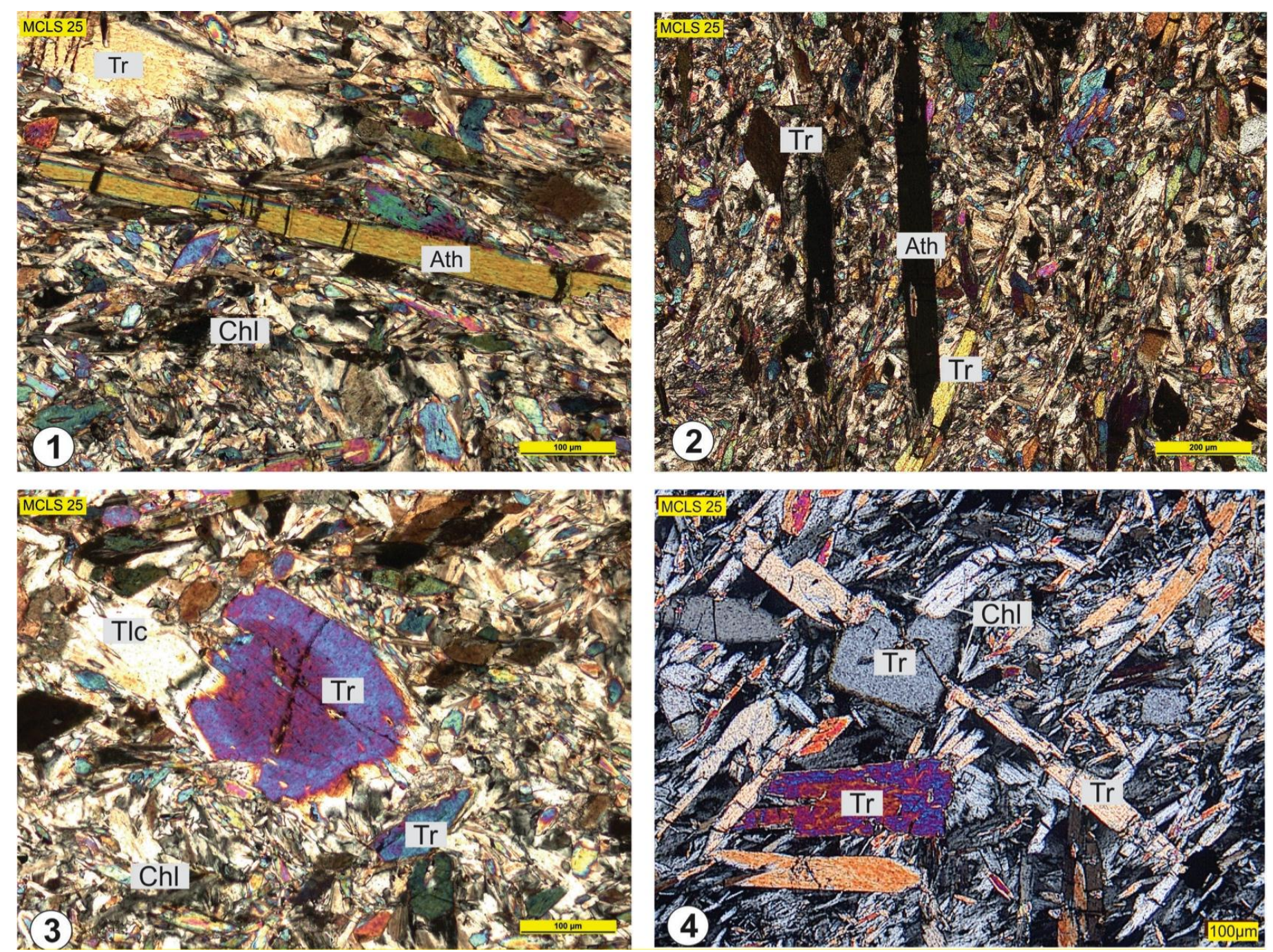

Figura 17. Fotomicrografias em luz transmitida e polarizadores cruzados dos antofilita-clorita-tremolita xistos. (1) porfiroblasto de antofilita em meio a matriz constituída por clorita e tremolita; (2) cristal prismático de ortoanfibólio (antofilita) com extinção reta; (3) porfiroblastos de tremolita, com bordas alteradas, possivelmente para antofilita, com talco em sua volta, provavelmente decorrente da desestabilização da tremolita; e (4) porfiroblastos de tremolita com bordas alteradas. Abreviações: Ath = antofilita; Chl = clorita; Tlc = talco; $\operatorname{Tr}=$ tremolita. 

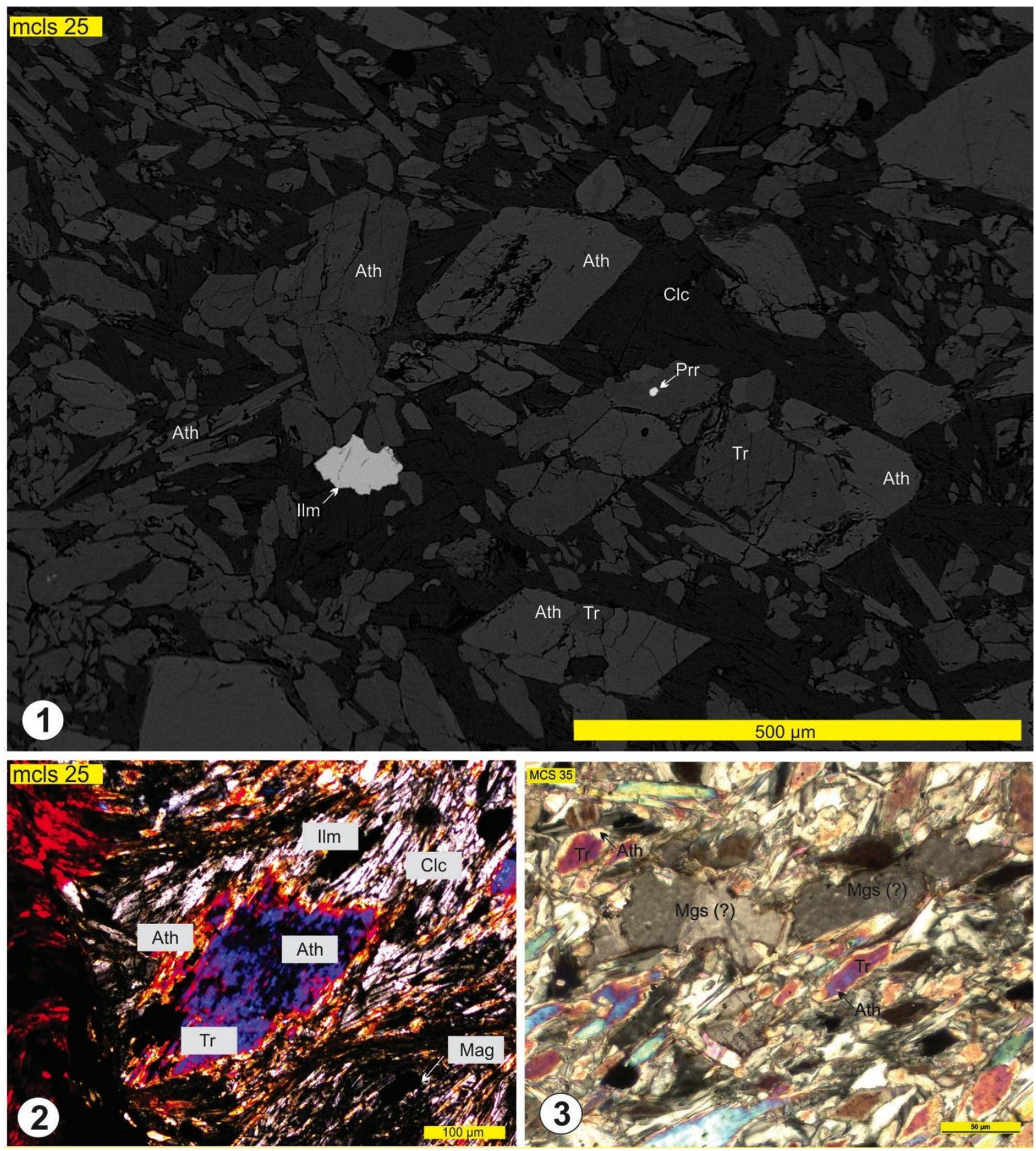

Figura 18. (1) Imagem de elétrons retro-espalhados obtida em microscopia eletrônica de varredura (MEV) mostrando as relações de contato entre os anfibólios. Notar que geralmente a antofilita ocorre nas bordas e nos planos de fraqueza dos cristais de tremolita, substituindo-a. A imagem mostra também a presença de ilmenita e pequena inclusão de pirrotita na tremolita; (2) cristal de tremolita substituído por antofilita e opacos tanto no centro como nas bordas (luz transmitida; polarizadores cruzados); e (3) presença significante de carbonato (magnesita?) nas rochas dessa unidade (luz transmitida; polarizadores cruzados). Abreviações: Ath = antofilita; $\mathrm{Clc}=$ clinocloro; $\mathrm{Ilm}=$ ilmenita; $\mathrm{Mag}=$ magnetita Mgs = magnesita; $\mathrm{Prr}=$ pirrotita; $\mathrm{Tr}=$ tremolita . 
O cummingtonita-magnetita-clorita-tremolita xisto possui coloração verde escura (Fig. 19-1) e granulação fina. Apresenta foliação (Sn) contínua, clivagem de crenulação bem desenvolvida (Sn+1; Fig. 19-2) e foliação milonítica, na qual os minerais opacos se alinham, formando uma foliação espaçada disjuntiva e onde o espaço microlítico é composto por tremolita. A foliação milonítica é subparalela à Sn. Nas porções menos cisalhadas, apresentam textura nematoblástica, caracterizada pela orientação dos prismas de anfibólios, porfiroblástica, definida pela primeira geração de anfibólios e pseudomórfica, na qual os cristais de clorita substituem os de tremolita.

Mineralogicamente é composto por clorita (30-50\%), cummingtonita (5 - 10\%), tremolita $(40-50 \%)$ e magnetita $(5-10 \%)$, e normalmente apresentam talco, serpentina e limonita (Fig. 19-3) subordinados.

A tremolita ocorre como (i) porfiroblastos da primeira geração (Fig. 19-4), submilimétricos, nos quais é possível reconhecer uma foliação interna definida pelo alinhamento de inclusões de opacos, discordante da foliação $\mathrm{Sn}$, indicando sua blastese anterior ao desenvolvimento dessa foliação (pré-Sn). A xistosidade Sn é definida pela orientação de uma (ii) segunda geração de tremolita que ocorre como finos cristais prismáticos ou com arranjo fibro-radiado. A cummingtonita ocorre na forma de lamelas de exsolução na tremolita ou nas bordas dessa (Fig. 19-4 e Fig. 20-1). Os minerais opacos apresentam hábito característico da magnetita, com presença associada de limonita e ilmenita nos planos de fraqueza (Fig. 19-3 e Fig. 20-2 e 3). A clorita é representada por clinocloro de granulação submilimétrica, pleocróica e, comumente, substitui os cristais de tremolita da primeira geração ao longo dos seus planos de clivagem e fraturas (Fig. 19-5) e orienta-se também segundo os planos da Sn+1 (Fig. 19-6).

Os clorita-(Mg)cummingtonita xistos possuem coloração verde-clara e granulação fina e apresentam foliação bem desenvolvida, definida pela orientação preferencial dos cristais de anfibólio. São compostas predominantemente por $(\mathrm{Mg})$ cummingtonita (70 - 85\%), com clorita $(5-10 \%)$, talco $(1-5 \%)$, tremolita $(1-5 \%)$, magnetita $(1-3 \%)$ e limonita subordinados.

Os cristais de anfibólio são representados por duas variedades: os transparentes (tremolita) e os pleocróicos (Mg-cummingtonita). A tremolita é substituída pela $\mathrm{Mg}$ cummingtonita em grande parte da rocha (Fig. 20-1) e ocorre em raros cristais (Fig. 21-1). Porfiroblastos de tremolita também apreentam-se substituídos e envolvidos por magnetita (Fig. 20-2), que apresenta localmente exsoluções ilmenita (Fig. 20-3). O talco substitui a Mgcummingtonita (Fig. 21-2), enquanto a clorita ocorre como cristais hipidiomórficos, com maclas bem definidas (Fig. 21-3 e Fig. 21-4). 

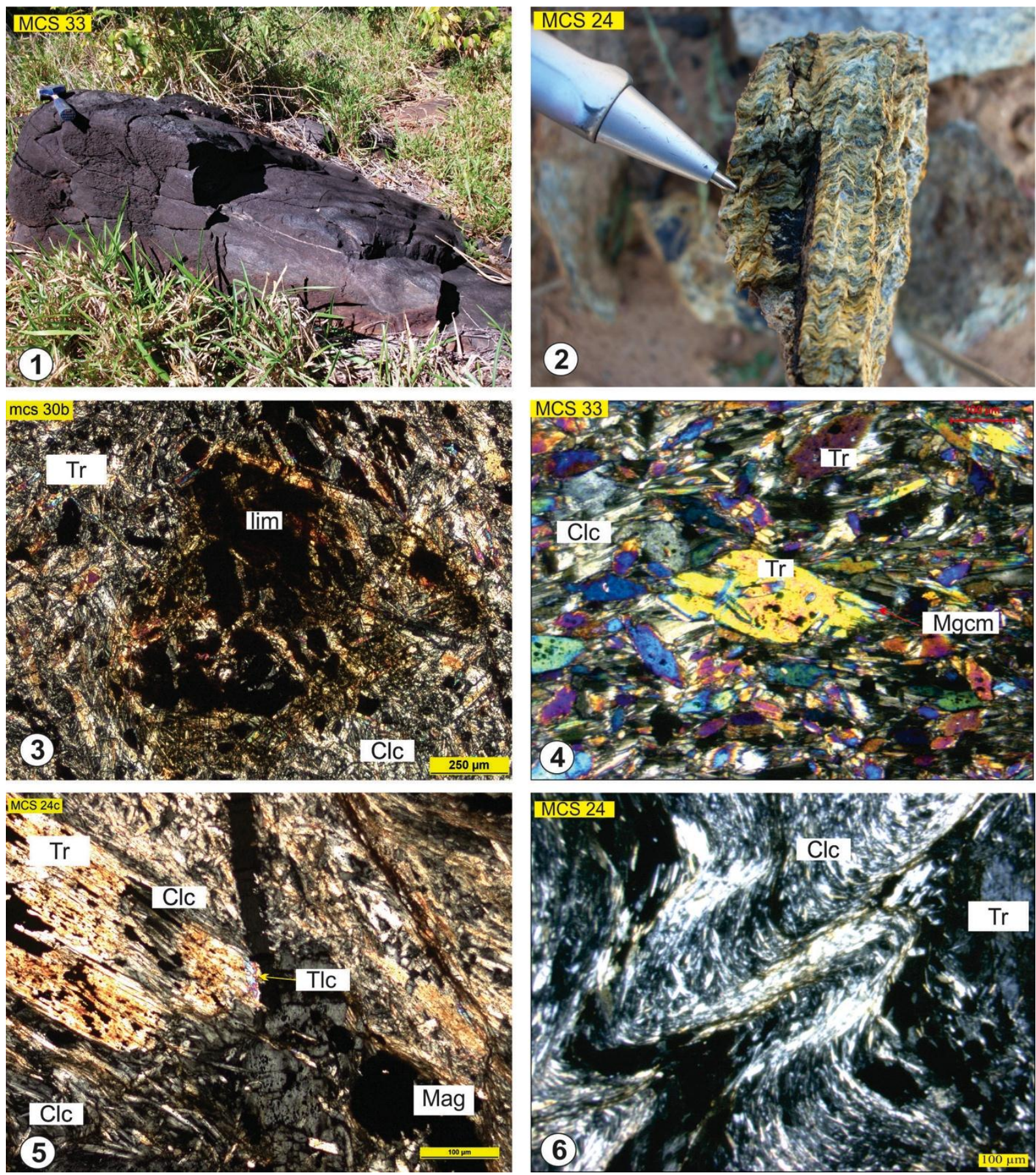

Figura 19. (1) Modo de ocorrência, geralmente em pequenos blocos rolados, do cummingtonita-magnetitaclorita-tremolita xisto; (2) detalhe da clivagem de crenulação em amostra de cummingtonita-magnetita-cloritatremolita xisto; (3) cristais prismáticos de tremolita associada a magnetita parcialmente limonitizada (fotomicrografia em luz transmitida; polarizadores cruzados); (4) rocha constituída predominantemente por tremolita, com rara ocorrência de Mg-cummintonita em sua borda (fotomicrografia em luz transmitida; polarizadores cruzados); (5) cristal de tremolita substituído parcialmente por clorita (no centro, bordas e fraturas) e por talco em sua borda (fotomicrografia em luz transmitida; polarizadores cruzados); (6) clorita magnesiana, associada à magnetita, orientada no plano da foliação Sn e clivagem de crenulação (fotomicrografia em luz transmitida; polarizadores cruzados). Abreviações: $\mathrm{Clc}=$ clinocloro; $\mathrm{Lim}=$ limonita; $\mathrm{Mag}=$ magnetita; $\mathrm{Mgcm}=$ magnésio-cummingtonita; $\mathrm{Tl} c=$ talco; $\mathrm{Tr}=$ tremolita 

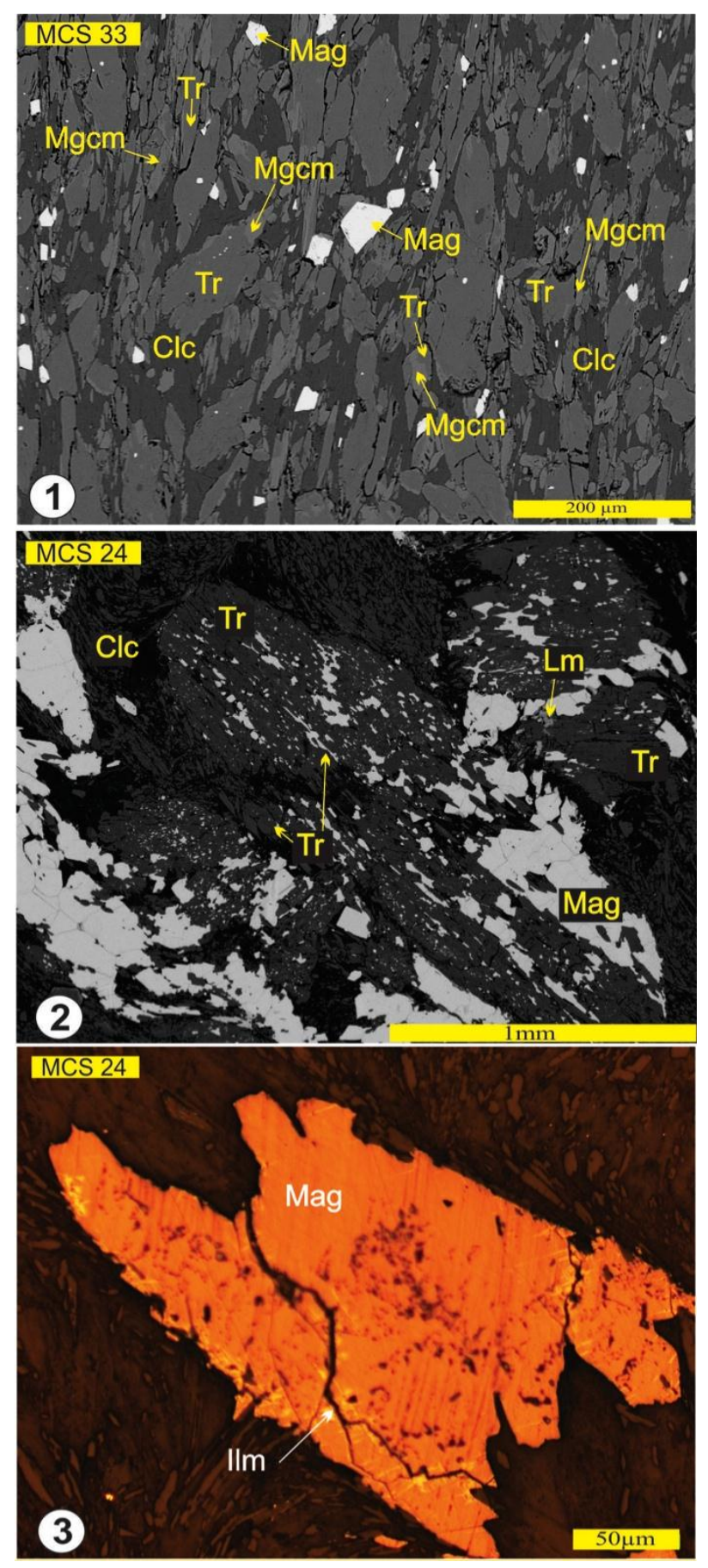

Figura 20. (1) Imagem de elétrons retro-espalhados obtida por microscopia eletrônica de varredura (MEV) mostrando as feições texturais entre os diferentes anfibólios no cummingtonita-magnetitaclorita-tremolita xisto. A Mg-cummingtonita substitui os cristais de tremolita, principalmente nas suas bordas. Também podem ser observadas na imagem a clorita associada com os cristais de tremolita e magnetita euhédrica a subeuhedral; (2) cristais de tremolita intercrescida à magnetita, e presença de limonita como produto de alteração da magnetita (imagem de elétrons retro-espalhados); (3) cristal de magnetita com exsolução de ilmenita nos planos de fraqueza. Abreviações: Clc = clinocloro; Ilm = ilmenita; Lm = limonita; Mag = magnetita; $\mathrm{Mgcm}=$ magnésio-cummingtonita; $\mathrm{Tr}=$ tremolita . 

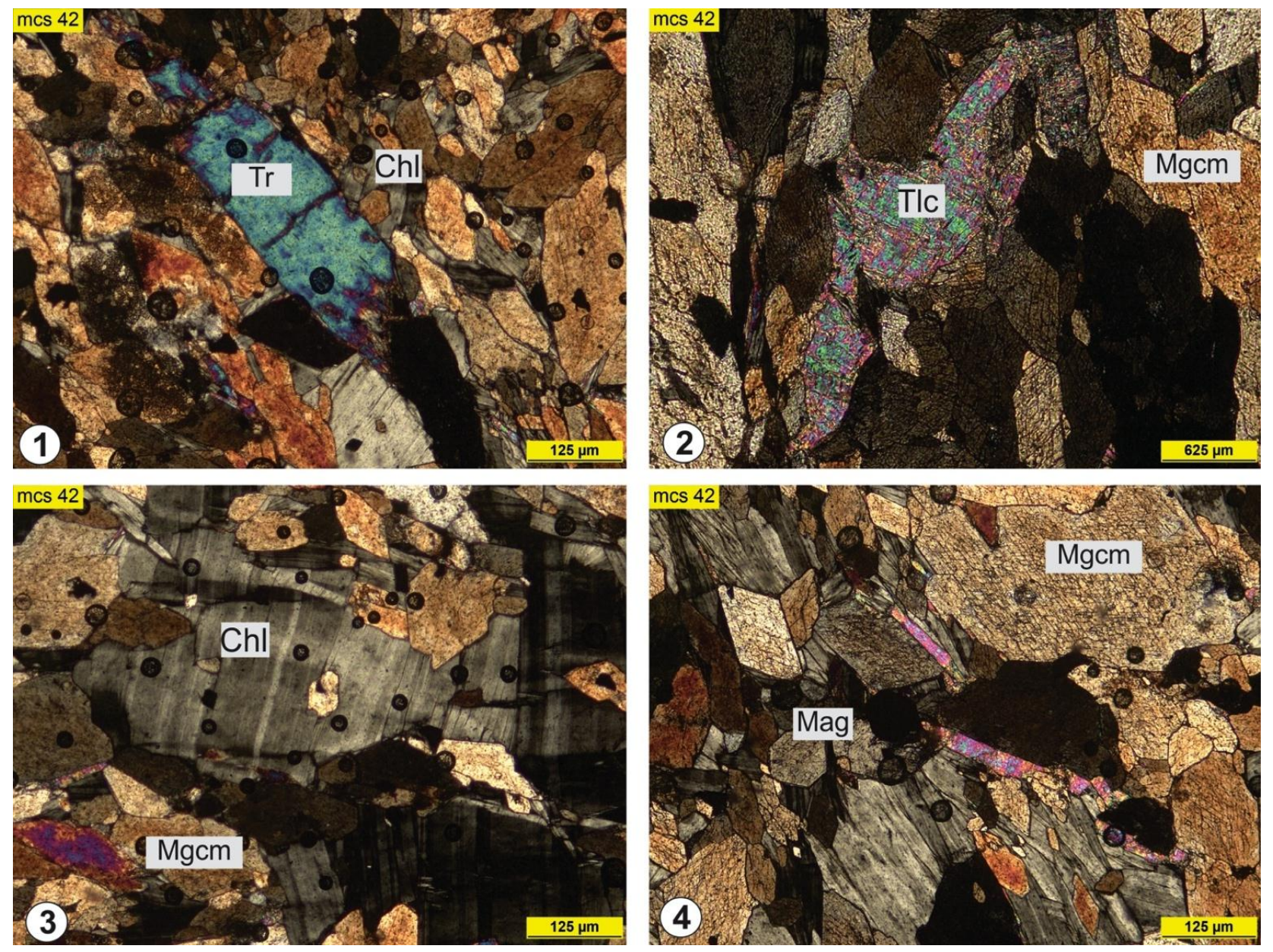

Figura 21. Aspectos petrográficos dos clorita-(Mg)cummingtonita xistos. (1) Raros cristais de tremolita, parcialmente alterados ao longo de suas bordas, em meio aos cristais de Mg-cummingtonita e clorita; (2) talco retrometamórfico substituindo a cummingtonita; (3) cristais hipidiomórficos de clorita, com maclas bem definidas; e (4) arranjo de cristais de Mg-cummingtonita, exibindo textura decussada, juntamente com clorita e talco. Fotomicrografias em luz transmitida e polarizadores cruzados. Abreviações: $\mathrm{Chl}=$ clorita; $\mathrm{Mag}=$ magnetita; $\mathrm{Mgcm}=\mathrm{Mg}$-cummingtonita; $\mathrm{Tlc}=\mathrm{talco} ; \mathrm{Tr}=$ tremolita. 
Os clorita-actinolita xistos apresentam coloração verde-acinzentada, granulação fina a média, com foliação Sn muito bem desenvolvida (Fig. 22-1). São compostos por clorita (25 - 40\%), actinolita $(60-70 \%)$, magnetita $(1-4 \%)$ e talco $(\operatorname{tr}-1 \%)$.

A actinolita ocorre como: (i) porfiroblastos, nem sempre alinhados no plano da foliação Sn ou com a foliação os contornando (Fig. 22-3 e 5) e (ii) cristais finos, alongados e orientados no plano da foliação (Fig. 22-2 e 4). Em alguns porfiroblastos é possível observar suas bordas substituídas por clorita. Clorita também orienta-se ao longo do plano da foliação. Os cristais de magnetita estão estirados e raramente apresentam o hábito euhedral (Fig. 22-6). Talco, retrometamórfico, ocorre nas bordas dos porfiroblastos de tremolita e em sombras de pressão.

A amostra (mcls 19a), classificada como edenita-clorita xisto, é verde escura e fina e apresenta edenita (35\%), clorita (60\%) magnetita (4\%) e serpentina (1\%). Os cristais de edenita possuem baixa birrefringência e normalmente estão envoltos pelos cristais de clorita magnesiana (Fig. 23-1 a 23-3), definindo a foliação Sn. Antofilita também foi identificada nessa amostra em análise de difração de raios-X, todavia, petrograficamente não foi possível reconhecê-la. A magnetita, euhédrica e orientada no plano da foliação Sn, apresenta-se parcialmente corroída, tanto no centro como nas bordas dos cristais (Fig. 23-4), enquanto a serpentina ocorre como produto da alteração do anfibólio, geralmente nas bordas e planos de fraqueza

O clorita-fluoroedenita xisto (mcs 11) também apresenta cor verde escura e granulação fina (Fig. 24-1) e difere do litotipo anterior devido à predominância de anfibólio (65\%) associado com clorita (30\%), magnetita euhédrica (4\%) e talco (1\%). Os cristais de anfibólio, segundo análise de difração de raios-X, apresentam composição de fluoroedenita [Na, $\left.\mathrm{Ca}_{2} \mathrm{Mg}_{5}\left(\mathrm{Si}_{7} \mathrm{Al}\right) \mathrm{O}_{22} \mathrm{~F}_{2}\right]$ e antofilita, embora petrograficamente não tenha sido possível reconhecer a antofilita. Entretanto, as bordas dos cristais de fluoroedenita encontram-se alteradas, de modo análogo ao de outras unidades citadas acima, sugerindo também alteração para antofilita (Fig. 24-2 e 3). Análise de difração de raios-X indicou a presença de níquel no retículo cristalino da clorita, que seria classificada como nimita $\left[\left(\mathrm{Ni}, \mathrm{Mg}, \mathrm{Fe}^{++}\right)_{5} \mathrm{Al}\left(\mathrm{Si}_{3} \mathrm{Al}\right) \mathrm{O}_{10}(\mathrm{OH})_{8}\right]$. Talco é observado apenas localmente, substituindo a fluoroedenita (Fig. 24-4). 

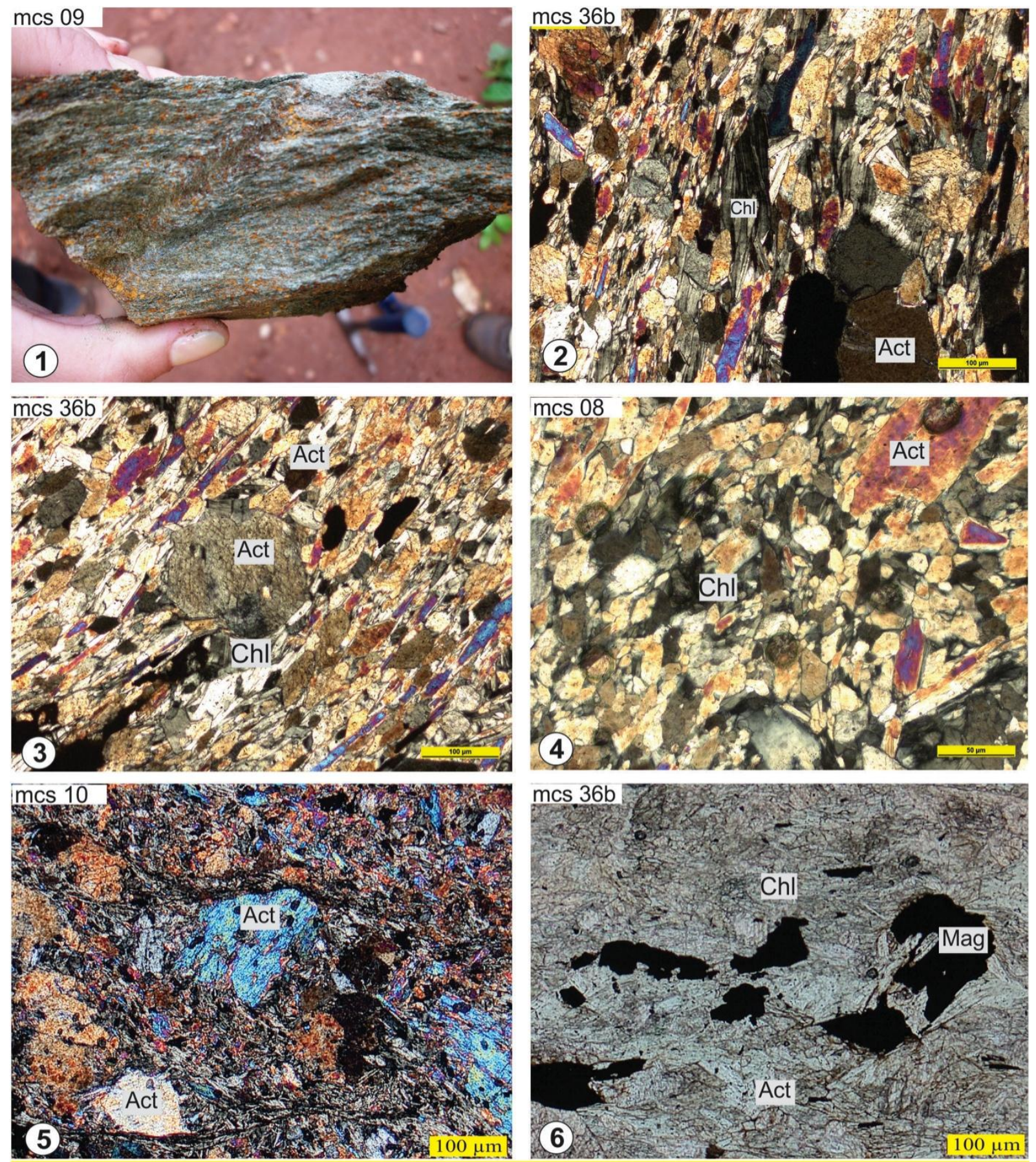

Figura 22. Aspectos petrográficos dos clorita-actinolita xistos. (1) Clivagem de crenulação em clorita-actinolita xisto com alguns porfiroblastos de actinolita alterados pelo intemperismo; (2) e (3) cristais porfiroblásticos de actinolita envoltos por clorita e cristais prismáticos e finos de actinolita (luz transmitida, polarizadores cruzados); (4) cristal de actinolita com bordas alteradas (luz transmitida, polarizadores cruzados); (5) porfiroblastos de actinolita com inclusão de magnetita (luz transmitida, polarizadores cruzados) e (6) cristais de magnetita estirados e alinhados no plano da foliação (luz transmitida, polarizadores descruzados). Abreviações: Act $=$ actinolita; $\mathrm{Chl}=$ clorita; Mag = magnetita. 

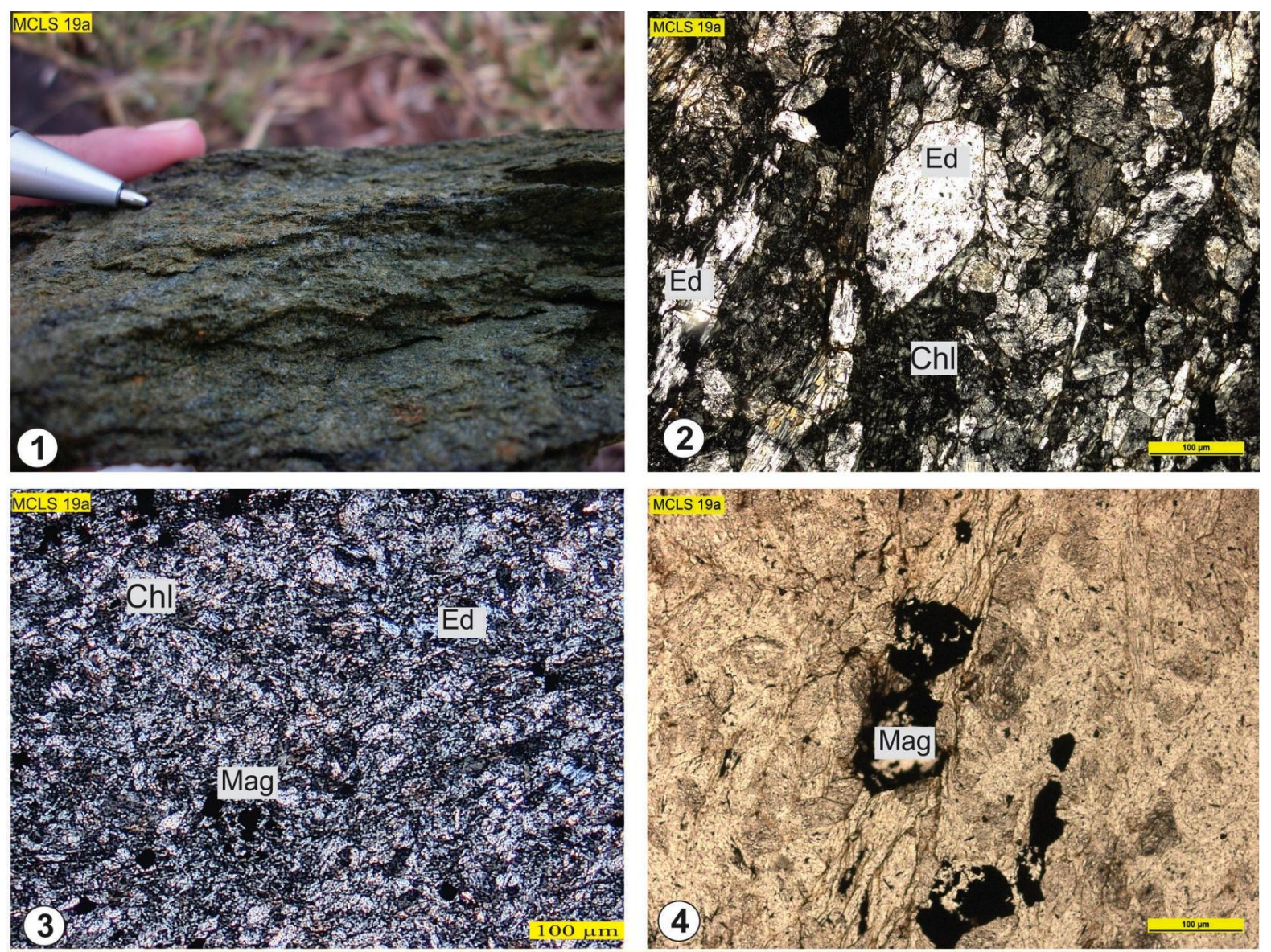

Figura 23. (1) Amostra de edenita-clorita xisto com foliação bem desenvolvida; (2) Edenita com baixa cor de interferência e clorita magnesiana orientadas ao longo do plano de foliação Sn (luz transmitida, polarizadores cruzados); (3) detalhe da textura lepidonematoblástica, com anfibólio e clorita alinhados no plano da foliação (luz transmitida, polarizadores cruzados); (4) magnetita parcialmente dissolvida e com corrosão nas bordas e no centro (luz transmitida, polarizadores descruzados). Abreviações: $\mathrm{Chl}=$ clorita; $\mathrm{Ed}=\mathrm{edenita}$; $\mathrm{Mag}=$ ........... 

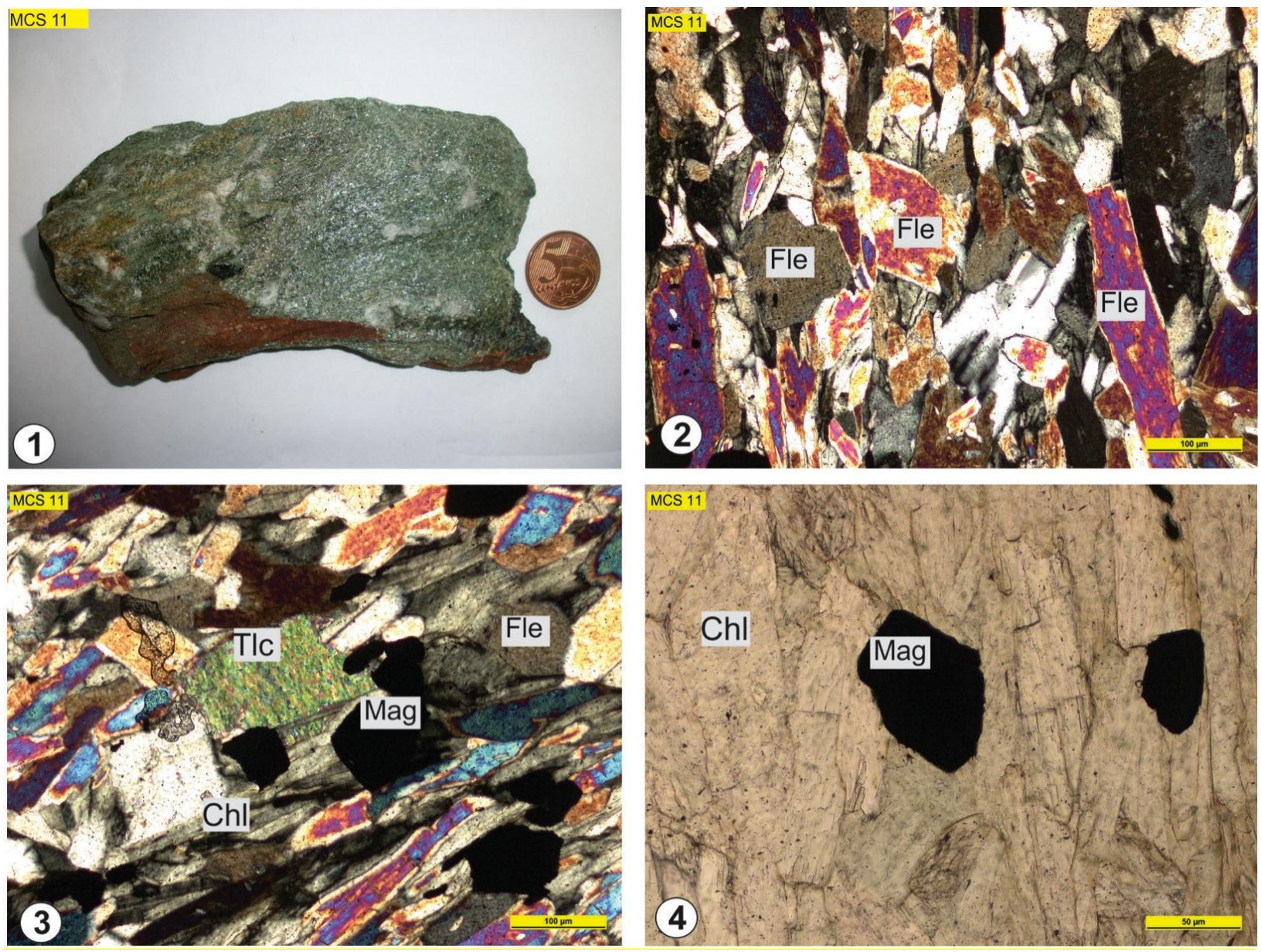

Figura 24. (1) Clorita-fluoroedenita xisto com brilho sedoso e xistosidade bem desenvolvida; (2) cristais de fluoroedenita com bordas alteradas, possivelmente substituídas por antofilita (luz transmitida, polarizadores cruzados); (3) Talco associado à magnetita em clorita-fluoroedenita xisto (luz transmitida, polarizadores cruzados); (4) cristal de magnetita subeuhedral associada ao anfibólio e à clorita (nimita) (luz transmitida, polarizadores descruzados). Abreviações: $\mathrm{Chl}=$ clorita; $\mathrm{Fle}=$ fluoroedenita; $\mathrm{Mag}=$ magnetita; $\mathrm{Tl} \mathrm{c}=$ talco . 
O cloritito aflora como blocos rolados ou in situ (Fig. 25-1) e representa rocha aproximadamente monominerálica, com foliação anastomosada bem desenvolvida e clivagem de crenulação, na qual os minerais opacos se alinham preferencialmente. É composta predominantemente por clorita $(90-95 \%)$ e minerais opacos $(5-10 \%)$, representados principalmente por porfiroblastos de magnetita (Fig. 25-2). Apatita, zircão, rutilo e monazita (tr $-1 \%$ ), subordinados, além de serpentina (crisotila), carbonato (dolomita) e quartzo também são reconhecidos. Mais raramente foi observado anfibólio, provavelmente antofilita, além de resquício de biotita substituída por clorita. A clorita possui granulação fina $(0,6 \mathrm{~mm})$, é fortemente pleocroica e ocorre orientada segundo a foliação Sn (Fig. 25-3 e 25-4). Análise de EDS acoplado à Microscópio Eletrônico de Varredura (MEV) indicou composição de clinocloro $\left.\left[\mathrm{Mg}, \mathrm{Fe}^{++}\right)_{5} \mathrm{Al}\left(\mathrm{Si}_{3} \mathrm{Al}\right) \mathrm{O}_{10}(\mathrm{OH})_{8}\right]$ para a clorita.

Os minerais opacos são representados por magnetita, cromomagnetita e ilmenita. É comum a presença de magnetita porfiroblástica, xenomórfica a hipidiomórfica, localmente com texturas de corrosão e substituição, com dimensões de até $0,8 \mathrm{~mm}$, apresentando bordas serrilhadas a planares. Alguns cristais possuem hábito esquelético, prismático e alongado. Os cristais menores normalmente encontram-se parcialmente estirados e orientados. A magnetita apresenta exsolução de ilmenita, principalmente em suas bordas e em planos de clivagem (Fig. 25-7). Por vezes, a magnetita foi totalmente substituída por ilmenita (Fig. 25-5). Os cristais de cromomagnetita $\left[\mathrm{Fe}^{2+}\left(\mathrm{Fe}^{3+}, \mathrm{Cr}^{3+}\right)_{2} \mathrm{O}_{4}\right]$ apresentam bordas mais ricas em cromo, diminuindo o teor desse elemento no centro dos cristais. Na Fig. 25-6, é possível observar algumas lamelas mais escuras no centro dos cristais, nas quais o conteúdo de cromo é bem menor que as bordas. A apatita, com cor de interferência azulada, de segunda ordem, é subeuhédrica e apresenta granulação entre 0,2 - 0,6 mm. Os cristais de zircão são muito finos, ( $<0,2 \mathrm{~mm}$ a submilimétricos), e por vezes são envolvidos por halos pleocróicos, enquanto os cristais de monazita têm granulação fina a média (0,2 - 0,5 mm; Fig. 25-8). 

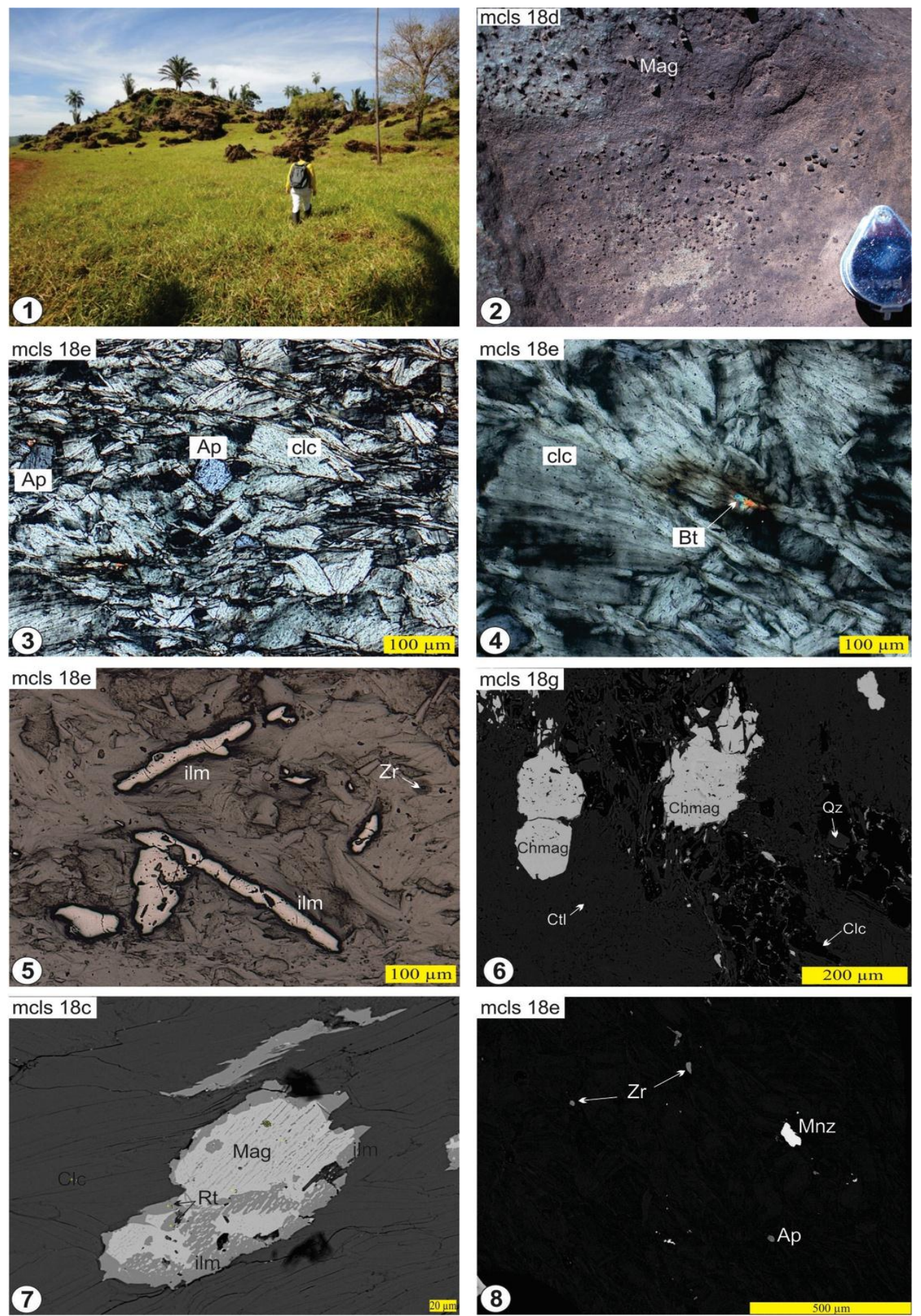

Figura 25. (1) Modo de ocorrências dos clorititos, em blocos; (2) amostra de cloritito com porfiroblastos idiomórficos de magnetita; (3) aspecto geral ao microscópio, com cristais de clorita fortemente pleocróica, orientados segundo o plano da foliação Sn, com a presença de cristais de apatita com cor de baixa birrefringência (luz transmitida, polarizadores cruzados); (4) resquício de biotita em meio aos cristais de clorita (luz transmitida, polarizadores cruzados); (5) imagem de luz refletida dos cristais alongados de ilmenita e pequeno cristal de zircão com halo pleocróico; (6) Imagem de elétrons retro-espalhados obtida por microscopia eletrônica de varredura (MEV) de cromomagnetita, na qual é possível observar as bordas mais ricas em cromo; (7) Imagem de elétrons retro-espalhados obtida por microscopia eletrônica de varredura (MEV) de cristal de magnetita com exsolução de ilmenita no centro dos cristais e substituição por ilmenita e rutilo nas bordas e nos planos de fraqueza e (8) imagem de elétrons retro-espalhados mostrando cristais de zircão, monazita e apatita, comuns nos clorititos. Abreviações: $\mathrm{Ap}=$ apatita; $\mathrm{Bt}=$ biotita; $\mathrm{Clc}=$ clinocloro; $\mathrm{Chmg}=$ cromomagnetita; $\mathrm{Cst}=$ crisotila; Ilm = ilmenita; Mag = magnetita; $\mathrm{Mnz}=$ monazita; $\mathrm{Rt}=$ rutilo; $\mathrm{Zr}=$ zircão.

Dissertação de Mestrado - IG-USP - Soraya Damasceno Sousa - 2014 
Entre os litotipos metaultramáficos, também foi reconhecido olivina-hercinitaclorita-(Mg) hornblenda xisto com forte foliação milonítica. Esse apresenta coloração cinzaesverdeada e granulação fina (Fig. 26-1) e é constituída por olivina (10\%), hercinita (8 \%), clorita (20\%), Mg-hornblenda (60\%), serpentina (1\%) e magnetita (0 - 1\%). A Mghornblenda define a foliação e a textura decussada das porções em que predomina (Fig. 26-2).

A olivina apresenta-se fortemente estirada ao longo da foliação milonítica, além de serpentinizada e bastante intemperizada. Apresenta comumente cor ocre devido à limonitização (Fig. 26-3 e 26-4). Em análise de EDS acoplado ao MEV, a composição da olivina apresentou conteúdos semelhantes de $\mathrm{Mg}$ e Fe, com leve predominância de $\mathrm{Mg}$. A propriedade óptica desses cristais, em figura de interferência, apresentou sinal positivo, indicando uma olivina rica na molécula forsterita.

O espinélio hercinita ocorre no plano da foliação e geralmente encontra-se associados com os cristais de olivina (Fig. 26-5). Clorita apresenta baixa birrefringência, indicando sua composição magnesiana. Ocorre em formas de ripas orientadas ou não no plano da foliação (Fig. 26-6). Análise EDS acoplado ao MEV indicou composição de clinocloro $\left.\left[\mathrm{Mg}, \mathrm{Fe}^{++}\right)_{5} \mathrm{Al}\left(\mathrm{Si}_{3} \mathrm{Al}\right) \mathrm{O}_{10}(\mathrm{OH})_{8}\right]$ para a clorita. Os cristais de hornblenda são predominantemente do tipo magnesiano $\left[\mathrm{Ca}^{2} \mathrm{Mg}^{4}\left(\mathrm{Al}_{1} \mathrm{Fe}^{3+}\right) \mathrm{Si}_{7} \mathrm{AlO}_{22}(\mathrm{OH})_{2}\right]$, mas localmente variam para magnésio-ferri-hornblenda $\left[\mathrm{Ca}^{2} \mathrm{Mg}^{4}, \mathrm{Fe}^{+} \mathrm{AlSi}_{7} \mathrm{O}_{22}(\mathrm{OH})_{2}\right]$. A serpentina geralmente ocorre nas bordas e em fraturas dos cristais de olivina e hercinita, enquanto os opacos são representados por cromomagnetita $\left[\mathrm{Fe}^{2}\left(\mathrm{Fe}^{3+}, \mathrm{Cr}^{3+}\right)_{2} \mathrm{O}_{4}\right]$ (Fig. 26-6). 

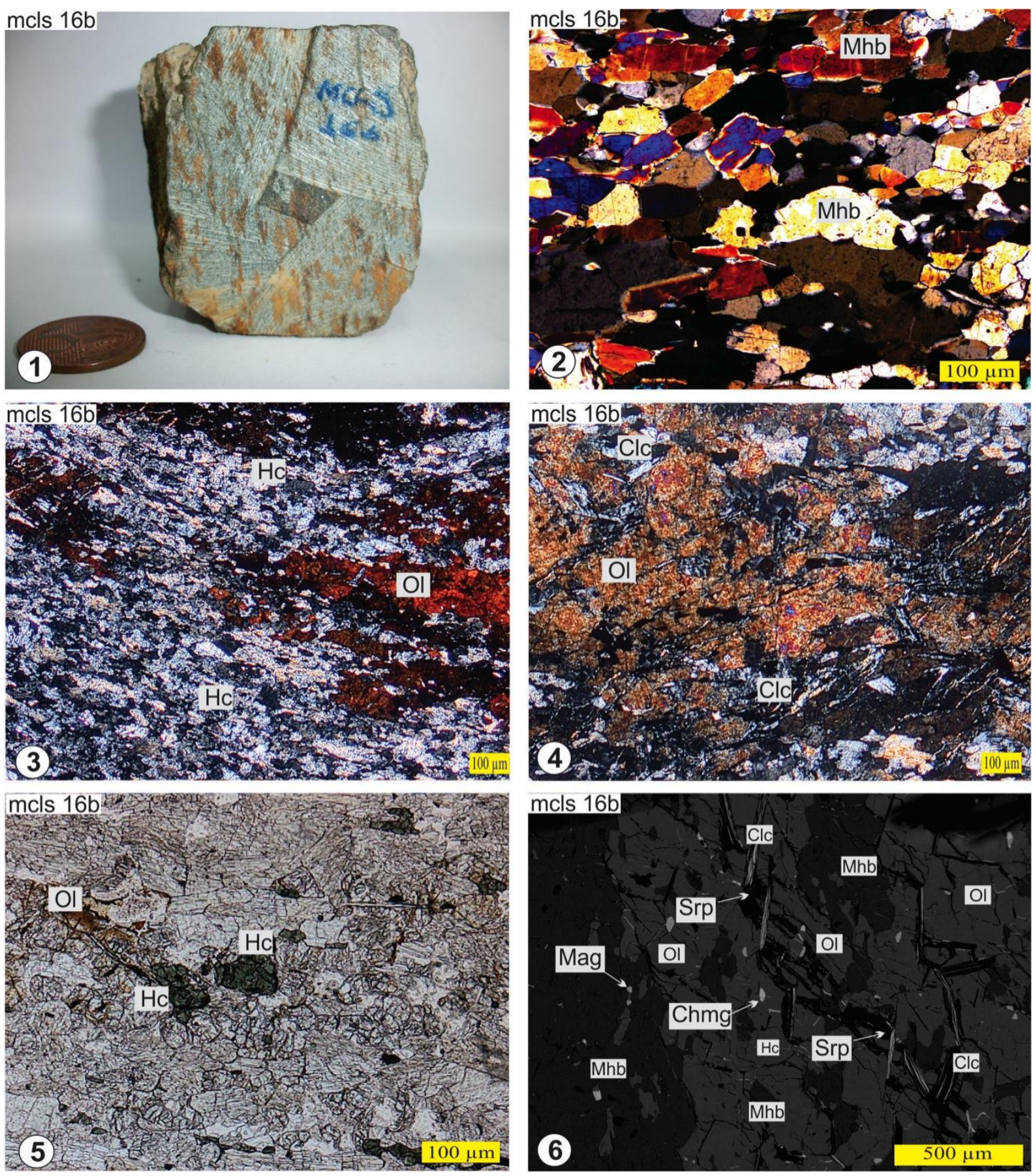

Figura 26. (1) Amostra de olivina-hercinita-clorita-(Mg) hornblenda xisto na qual é possível a observação dos cristais de olivina intensamente estirados e alterados pelo intemperismo, resultando em sua cor ocre; (2) relação de contato entre os cristais Mg-hornblenda, geralmente poligonal, no plano da foliação (luz transmitida, polarizadores cruzados); (3) e (4) olivina, limonitizada, com cor avermelhada, orientada e fortemente estirada, cortada e/ou substituída por clorita magnesiana e serpentina (luz transmitida, polarizadores cruzados); (5) Hercinita (verde) associada ao cristais de olivina (luz transmitida, polarizadores descruzados); (6) imagem de elétrons retro-espalhados obtida por microscopia eletrônica de varredura (MEV) onde observa-se a serpentina nas bordas da olivina, ripas de clorita discordante a foliação, cristais de cromomagnetita e magnetita. Abreviações: $\mathrm{Clc}=$ clinocloro; $\mathrm{Chmg}=$ cromomagnetita; $\mathrm{Hc}=$ hercinita; $\mathrm{Mag}=$ magnetita; $\mathrm{Mhb}=\mathrm{Mg}$ horblenda; $\mathrm{Ol}=$ olivina; $\operatorname{Srp}=$ serpentina. 


\subsubsection{Unidade Máfica}

Os metabasitos incluem Mg-hornblenda anfibolito foliado com coloração verdeescura e granulação fina a média. Mineralogicamente é constituído por Mg-hornblenda (60 80\%), incluindo Mg-hornblenda I (40 - 50\%) e Mg-hornblenda II (20 - 35\%), quartzo (5 $20 \%$ ), plagioclásio (5 - 20\%), sendo plagioclásio I (5 - 10\%) e plagioclásio II (10 - 15\%) e minerais subordinados, tais como opacos, titanita, apatita, turmalina e allanita ( $\operatorname{tr}-2 \%)$.

Texturalmente apresentam arranjo predominantemente granoblástico (Fig. 27-2), com cristais equidimensionais em contatos em $120^{\circ}$ e textura porfiroblástica, com grandes cristais de hornblenda, com extinção ondulante, formação de subgrãos e fraco pleocroísmo (Fig. 275). O arranjo dos cristais de $\mathrm{Mg}$-hornblenda define a foliação Sn, fina, pouco espaçada, por vezes transposta por foliação milonítica, definida pela orientação dos cristais de $\mathrm{Mg}$ hornblenda e por bandamento composicional entre minerais máficos e félsicos (Fig. 27-1). Nas faixas com predominância de hornblenda, a textura é nematoblástica e alterna-se a faixas constituídas por plagioclásio com textura granoblástica (Fig. 27-8). Em alguns microdomínios é também reconhecida uma foliação $\mathrm{Sn}+1$ e estrutura do tipo arco poligonal (Fig. 27-4).

Duas gerações de hornblenda são reconhecidas: a primeira (hornblenda I) é caracterizada pelos porfiroblastos e registra a partir de foliação interna definida pela orientação das inclusões de quartzo sin a pós-cinemática em relação à Sn-1, que teria sido transposta pela Sn em grande parte da rocha (Fig. 27-3); e a segunda (hornblenda II), gerada sin-Sn, é definida por cristais finos (Fig. 27-7).

O plagioclásio também está presente como porfiroblastos e finos cristais. Quartzo possui granulação muito fina $(<0,2 \mathrm{~mm})$, formação de sub-grãos e textura de recristalização. Os minerais opacos, principalmente magnetita, ocorrem de forma intersticial e alguns cristais apresentam dissolução nas regiões centrais e nas bordas. Cristais de turmalina com zoneamento típico, associado a opacos idiomórficos são comuns (Fig. 27-6). Cristais de titanita xenomorfa de granulação fina são comuns e ocorrem de forma disseminada e/ou associada aos opacos. 

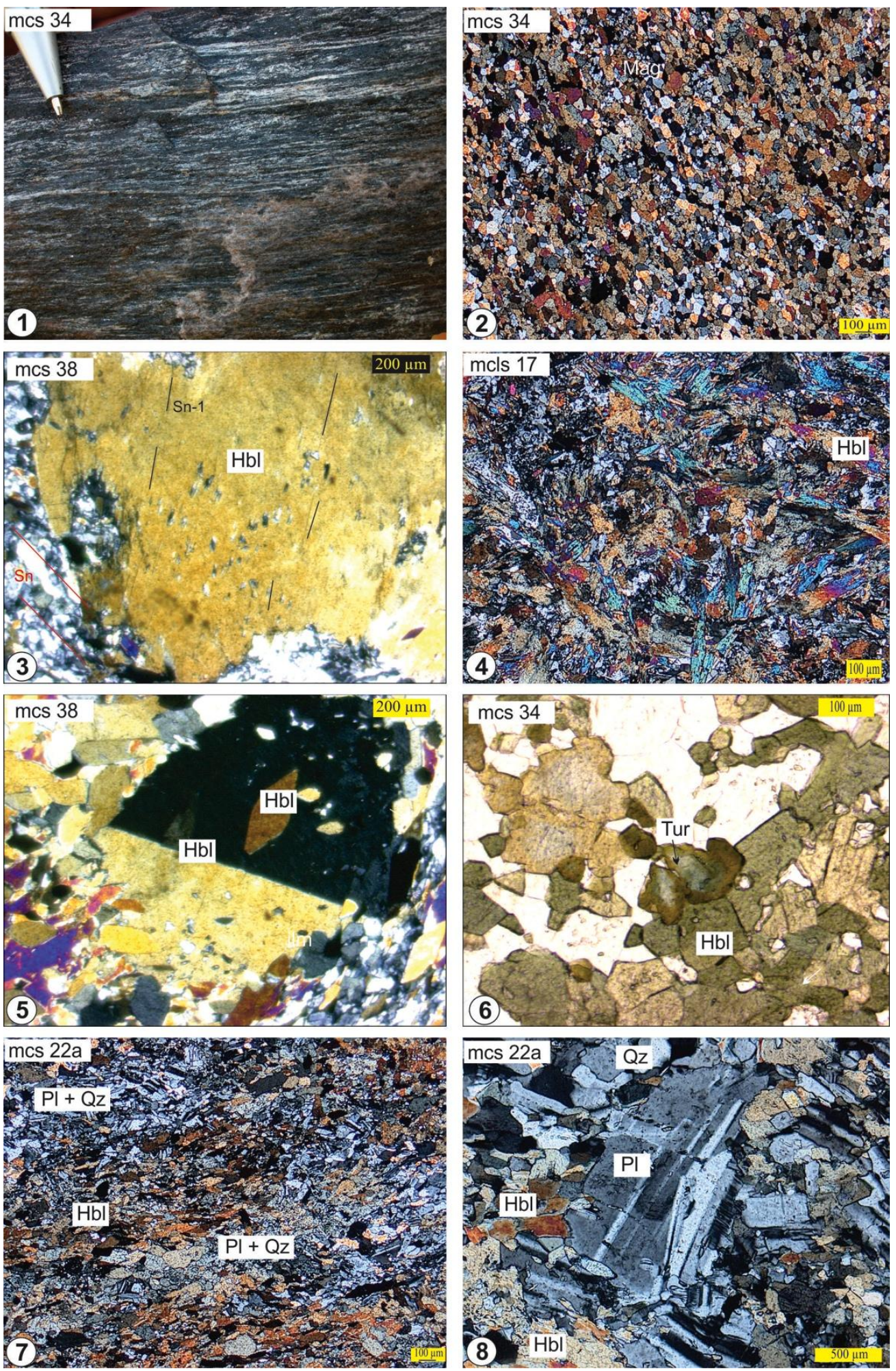

Figura 27. (1) Mg-hornblenda anfibolito foliado e com segregação metamórfica entre minerais máficos e félsicos; (2) aspecto geral da rocha com arranjo granoblástico a decussado; luz transmitida e polarizadores cruzados; (3) porfiroblastos de hornblenda com finas inclusões de quartzo orientadas, indicando geração sin a pós-cinemática em relação à Sn-1, que teria sido transposta pela Sn; luz transmitida e polarizadores cruzados; (4) cristais de Mg-hornblenda em forma fibro-radiado e estrutura do tipo arco poligonal; luz transmitida e polarizadores cruzados; (5) porfiroblastos de hornblenda com inclusão de outros cristais de hornblenda e quartzo; luz transmitida e polarizadores cruzados; (6) turmalina associada aos cristais de anfibólio; luz transmitida e polarizadores descruzados; (7) segregação metamórfica entre máficos e félsicos; luz transmitida e polarizadores cruzados; (8) Detalhe da primeira geração de plagioclásio, texturalmente mais grosso; luz transmitida e polarizadores cruzados. Abreviações: $\mathrm{Hbl}=$ hornblenda; $\mathrm{Pl}=$ plagioclásio; $\mathrm{Qz}=$ quartzo; Tur = turmalina. 
O hornblenda anfibolito apresenta aspecto granular hipidiomórfico, de granulação fina a média com cristais com tamanhos $\leq 0,5 \mathrm{~mm}$, que se distribuem de forma aleatória, sem uma orientação preferencial. Esse litotipo mostra em escala macroscópica coloração verdeescura com fraturas preenchidas por quartzo (Fig. 28-2). A associação mineral é definida por hornblenda (65 - 85\%), plagioclásio (10 - 25\%), quartzo (5 - 10\%), opacos (1 - 5\%), com apatita, titanita e zircão, subordinados (1\%). Apresenta textura decussada e possuem domínios com arranjo granoblástico definido pelos cristais de quartzo e plagioclásio (Fig. 28-3).

Essas rochas são compostas por cristais de hornblenda, de granulação fina, pleocróica, variando de verde-claro a verde-oliva, com contornos regulares e retos a inter-lobados entre si e com os demais minerais (Fig. 28-4 e 28-5).

Os cristais de plagioclásio são equigranulares de granulação fina, hipiomórficos com contornos regulares quando não alterados. Desenvolvem contatos retos a lobados entre si e com o anfibólio e, por vezes, ocorrem como cristais zonados, nos quais a geminação polissintética é mais preservada no centro e ausente nas bordas. Essa feição pode indicar uma fase de transição, onde o cristal de composição labradorítica passa para andesina. $O$ plagioclásio também apresenta geminação do tipo albita com alguns cristais, que mostram-se moderadamente alterados para sericita. Os cristais de quartzo apresentam granulação fina ( $\leq$ $0,03 \mathrm{~mm}$ ). Quando intensamente recristalizados formam cristais xenomorfos com contornos regulares, contatos retos entre si e com o plagioclásio, em porções microlíticas. Por vezes, ocorrem como cristais policristalinos formando mosaicos.

A titanita é euhédrica, fina e, geralmente, associa-se aos minerais opacos. A goethita é encontrada de forma disseminada. Raros cristais de biotita retrometamórfica ocorrem em cima de cristais de plagioclásio e algumas vezes substituindo a hornblenda. Os minerais opacos ocorrem com feição de dissolução nas bordas e principalmente nas porções centrais (Fig. 28$6)$. 

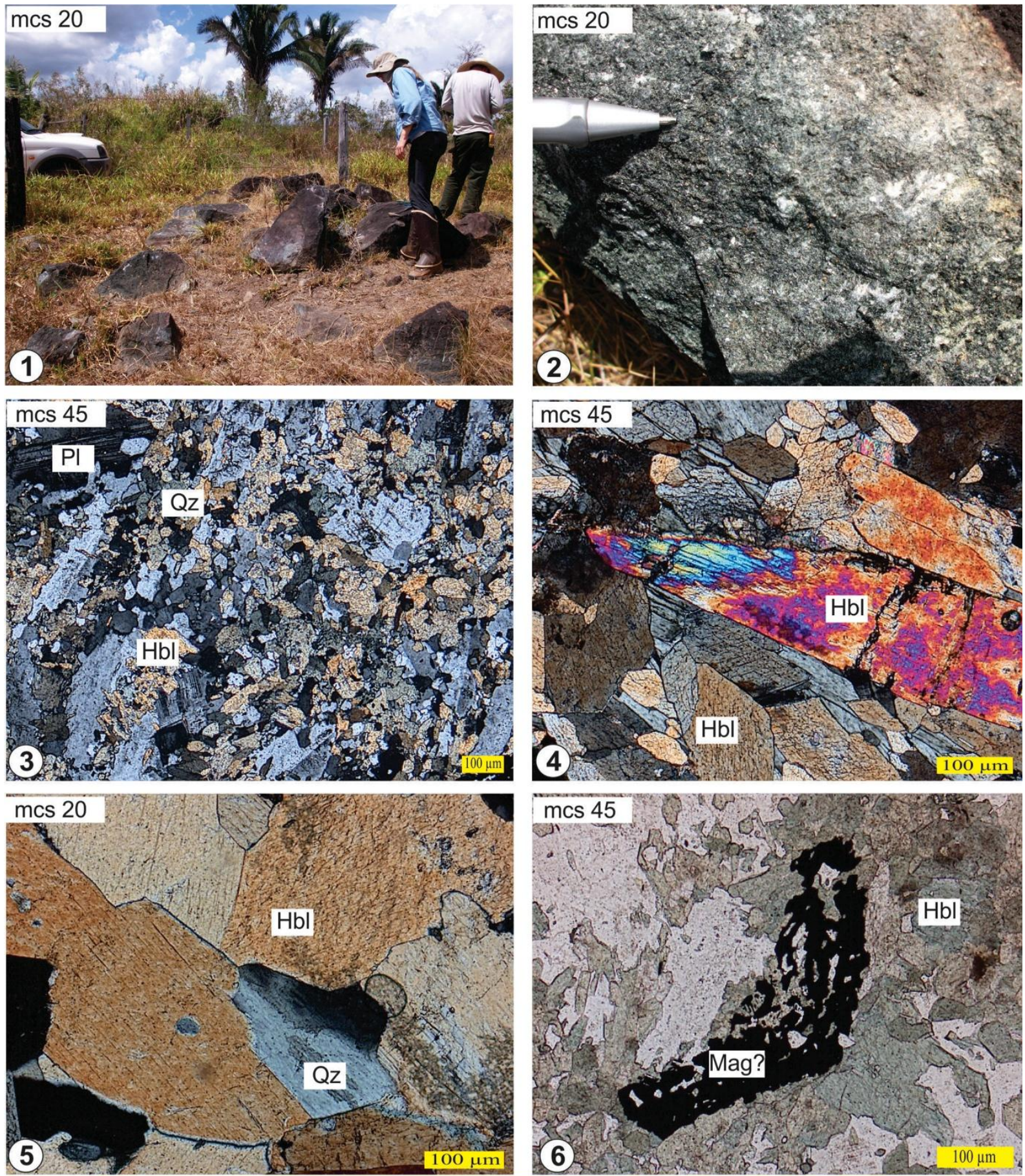

Figura 28. (1) Modo de ocorrência do hornblenda anfibolito, geralmente em blocos rolados; (2) detalhe da rocha, mostrando finos cristais de hornblenda; (3) presença de hornblenda, plagioclásio e quartzo no hornblenda anfibolito (luz transmitida e polarizadores cruzados); (4) relação de contato entre os cristais de hornblenda, alguns dos quais parcialmente alterados (luz transmitida e polarizadores cruzados); (5) relação de contato regular e reto entre cristais de hornblenda (luz transmitida e polarizadores cruzados); (6) possível magnetita com feição de dissolução nas bordas e partes centrais (luz transmitida e polarizadores descruzados). Abreviações: Hbl = hornblenda; $\mathrm{Pl}=$ plagioclásio; $\mathrm{Qz}=$ quartzo; $\mathrm{Mag}=$ magnetita. 


\subsubsection{Unidade Metapelítica}

Os muscovita-biotita xistos com granada são rochas de coloração bege e granulação grossa (Fig. 29-1 e 29-2). Mineralogicamente são compostas por quartzo (40 - 50\%), biotita (20 - 30\%), plagioclásio (5 - 10\%), muscovita (5 - 10\%) e, subordinadamente, almandina, apatita, clorita, ilmenita e hematita (4\%).

Apresentam xistosidade espaçada disjuntiva, localmente anastomosada, definida pela orientação preferencial dos cristais achatados de biotita, definindo uma textura lepidoblástica (Fig. 29-3 e 29-5). O espaço microlítico é composto por quartzo recristalizado e por plagioclásio.

Os cristais de quartzo são xenomórficos, finos $(0,02-0,05 \mathrm{~mm})$, apresentam textura bulging entre si, extinção ondulante contato poligonal com junção tríplice. Como produto de processos de recristalização, houve formação de novos grãos (neoblastos) (Fig. 29-4 e 29-6). A biotita é hipidiomórfica, possui coloração verde-acastanhada, pleocroísmo variando do amarelo claro ao marrom e, geralmente, encontra-se dobrada. Em análise de EDS acoplado ao MEV a biotita apresentou composição de siderofilita (Fig. 29-7).

Os cristais de muscovita são equigranulares de granulação média $(<0,10 \mathrm{~mm})$, com contatos retos entre si e com o plagioclásio e irregulares com a biotita. Apresenta orientação preferencial definindo textura lepidoblástica a localmente decussada (Fig. 29-3). O plagioclásio, de composição oligoclásio, possui geminação deformada, zoneamento, exsolução e inclusões ameboides ou vermiculares de quartzo (Fig. 29-8).

Os cristais de almandina são subeuhedrais e apresentam-se estirados e com sombra de pressão (Fig. 29-4 e 29-7). Foliação interna (Sn-1) pode ser reconhecida em porfroblastos de almandina, definida pela orientação de inclusões de muscovita e opacos, principalmente ilmenita (Fig. 29-4 e 29-7). A Sn-1 é discordante da Sn, definida pela orientação da biotita e da muscovita, além de levemente anastomosada. Tais relações indicam que a blastese da granada foi sin- a tardi tectônica em relação ao desenvolvimento da Sn-1 e anterior à Sn.

Clorita substitui localmente a biotita (Fig. 29-8). Allanita com halos pleocróicos também é reconhecida (Fig. 29-6). Os minerais opacos são representados por ilmenita e hematita (Fig. 29-7).

Foi reconhecida variação composicional nos litotipos interpretados como formados a partir de protólitos sedimentares. Em alguns casos esses não apresentam cristais de granada, porém, a mesma mineralogia e aspectos texturais foi reconhecida. 

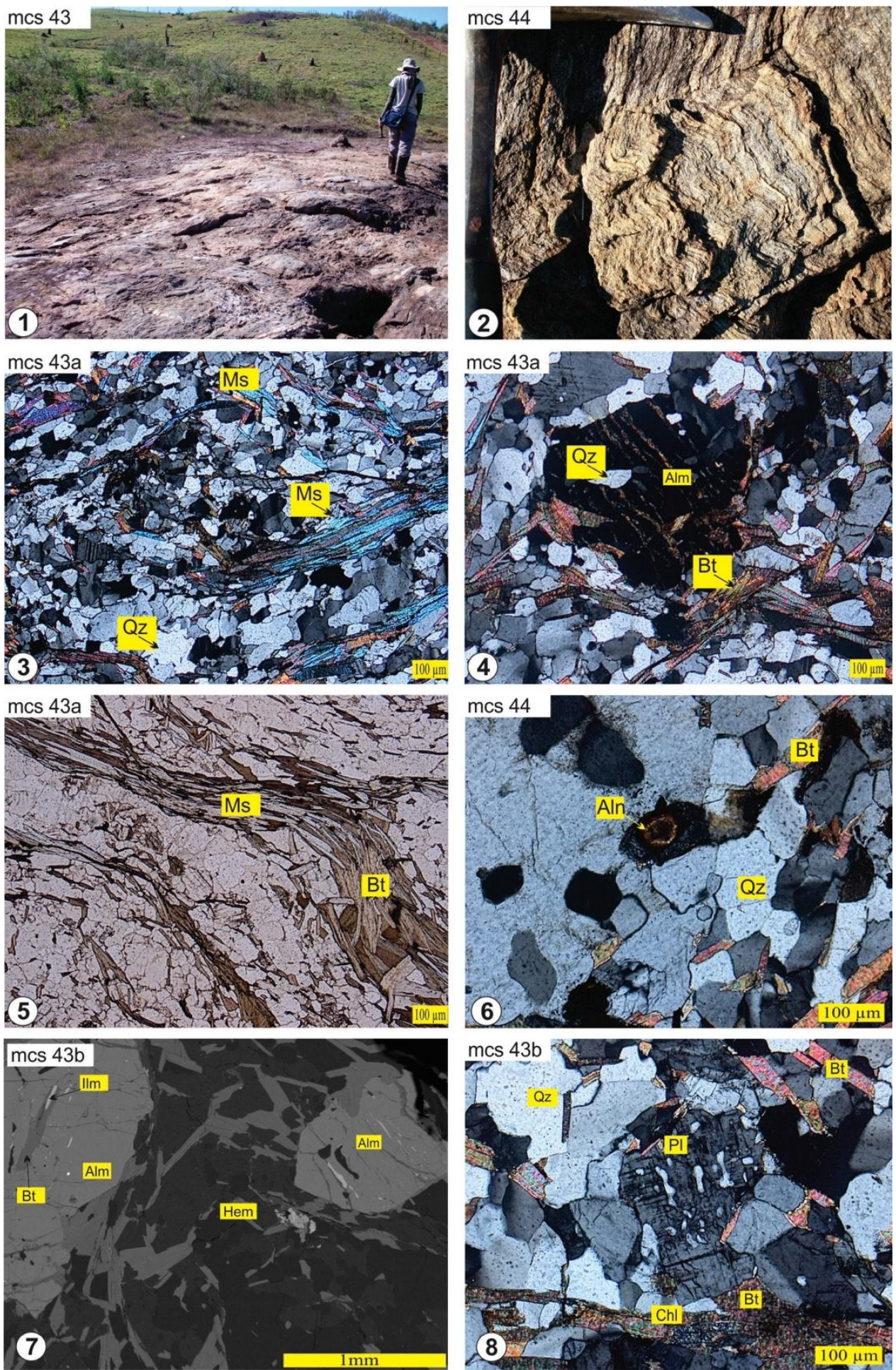

Figura 29. (1) modo de ocorrência do muscovita-biotita xisto com granada em afloramento extenso; (2) xistosidade bem desenvolvida e crenulada do muscovita-biotita xisto; (3) cristais de muscovita em textura lepidoblástica definindo uma foliação espaçada (luz transmitida, polarizadores cruzados); (4) cristal de almandina subeuhedral com biotita em suas bordas, com foliação interna $\mathrm{Sn}-1$, discordante da foliação externa, $\mathrm{Sn}$, da rocha (luz transmitida, polarizadores cruzados); (5) cristais de muscovita e biotita arqueados, com textura lepidoblástica (luz transmitida, polarizadores descruzados); (6) cristais de quartzo em textura bulging entre si, extinção ondulante e contato poligonal; ao centro, cristal de allanita com halo pleocróico (luz transmitida, polarizadores cruzados); (7) imagem de elétrons retro-espalhados obtida por microscopia eletrônica de varredura (MEV) na qual é possível observar lamelas de ilmenita e hematita na biotita; (8) inclusões de quartzo vermicular no plagioclásio (luz transmitida, polarizadores cruzados). Abreviações: Alm = almandina; $\mathrm{Aln}=$ alanita $; \mathrm{Bt}=$ biotita $; \mathrm{Chl}=$ clorita $; \mathrm{Hem}=$ hematita; $\mathrm{Ilm}=$ ilmenita; $\mathrm{Ms}=$ muscovita: $\mathrm{Oz}=$ quartzo.

Dissertação de Mestrado - IG-USP - Soraya Damasceno Sousa - 2014 


\subsubsection{Rocha Metavulcanoclástica}

As rochas metavulcanoclásticas são representadas por metatufos bastante intemperizados, com coloração variegada, avermelhada e com níveis em cor ocre, com xistosidade bem definida (Fig. 30-1).

Essas rochas são representadas por quartzo-clorita xisto e clorita xisto com opacos subordinados. Mineralogicamente são compostas por clorita $(80-94 \%)$, quartzo $(3-20 \%)$ e opacos $(\operatorname{tr}-3 \%)$. Agregados policristalinos de quartzo recristalizado apresentam aspecto anastomosado e podem representar vênulas deformadas ou níveis de chert (Fig. 30-4). São comuns cristais de quartzo euhedral, com bordas de crescimento, indicando origem vulcânica ou hidrotermal. Há evidências de duas gerações de clorita, que ocorre como: $(i)$ cristais maiores, com cor de interferência baixa (Fig. 30-2) e (ii) cristais finos, com pleocroísmo variando do verde-claro ao verde-azulado (Fig. 30-3). Os minerais opacos possuem hábito semelhante ao da magnetita, porém, no geral foram deformados e alguns cristais estão discordantes da foliação e com sombra de pressão (Fig. 30-3).
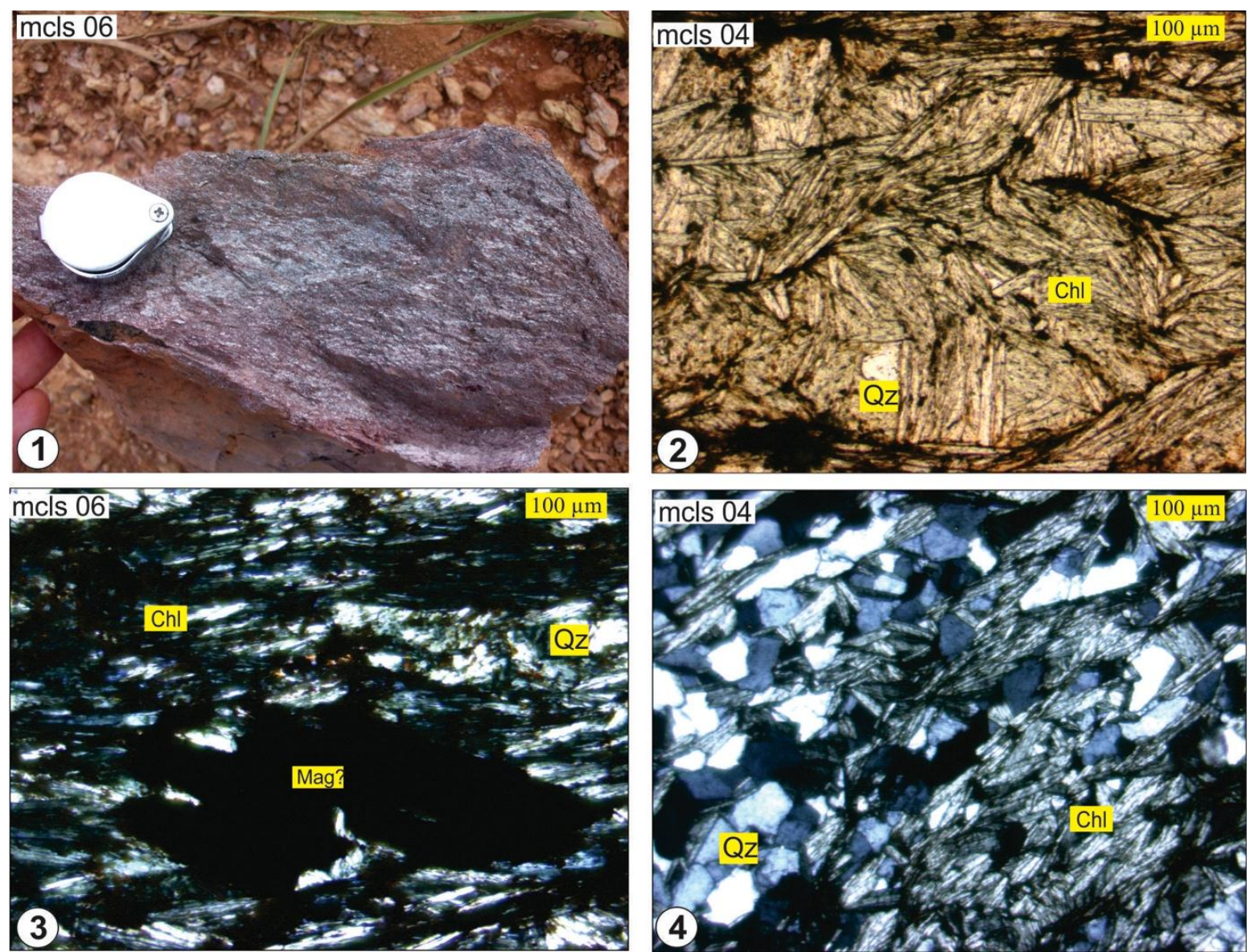

Figura 30. (1) aspecto das rochas metavulcanoclástica com cor avermelhada e variegada; (2) cristais de clorita alongados, orientados no plano da foliação (luz transmitida, polarizadores descruzados); (3) possivelmente cristal de magnetita, que foi deformado e orientada, envolto por finos cristais de clorita e grãos de quartzo (luz transmitida, polarizadores cruzados); (4) quartzo que possivelmente representa níveis de chert metamorfisado e cisalhado (luz transmitida, polarizadores cruzados). Abreviações: Chl = clorita; Mag = magnetita; $\mathrm{Qz}=$ quartzo. 


\subsubsection{Rochas Gabroicas}

Os gabros presentes na área são faneríticos, isotrópicos, mesocráticos e possuem granulação média (0,6 a 0,9 mm; Fig. 31-1). São compostas por plagioclásio (45\%), clinopiroxênio (30\%), hornblenda (20\%) e opacos (5\%). Apresentam textura subofítica caracterizada por ripas de plagioclásio e clinopiroxênio intersticial com alta birrefringência, por vezes com textura gráfica (Fig. 31-2).Os cristais de plagioclásio exibem contornos regulares e contatos retos entre si e com o clinopiroxênio e geminação do tipo albita, podendo ocorrer ainda albita periclina. Os cristais apresentam-se em sua grande maioria zonados e suas propriedades ópticas indicam que apresenta composição de andesina cálcica $\left(\mathrm{An}_{45}\right)$ no centro e composição mais sódica nas bordas, correspondente à oligoclásio cálcico $\left(\operatorname{An}_{25}\right)$.

Os cristais de clinopiroxênio são hipidiomórficos, apresentam contornos regulares com o plagioclásio e irregulares entre si, possuem relevo moderado e cor de interferência máxima rosa de segunda ordem (Fig. 31-3) com características ópticas de augita. Subordinadamente cristais de hábito tabular com baixa birrefringência e com sinal óptico biaxial positivo podem também representar piogenita.

Os cristais de hornblenda são subautomorfos a xenomorfos, médios e de contornos irregulares (Fig. 31-4) e ocorrem associado aos cristais clinopiroxênio. Os minerais opacos (magnetita e/ou ilmenita) ocorrem como cristais equigranulares finos $(\sim 0,2 \mathrm{~mm})$, hipidiomorfos, por vezes idiomórficos. 

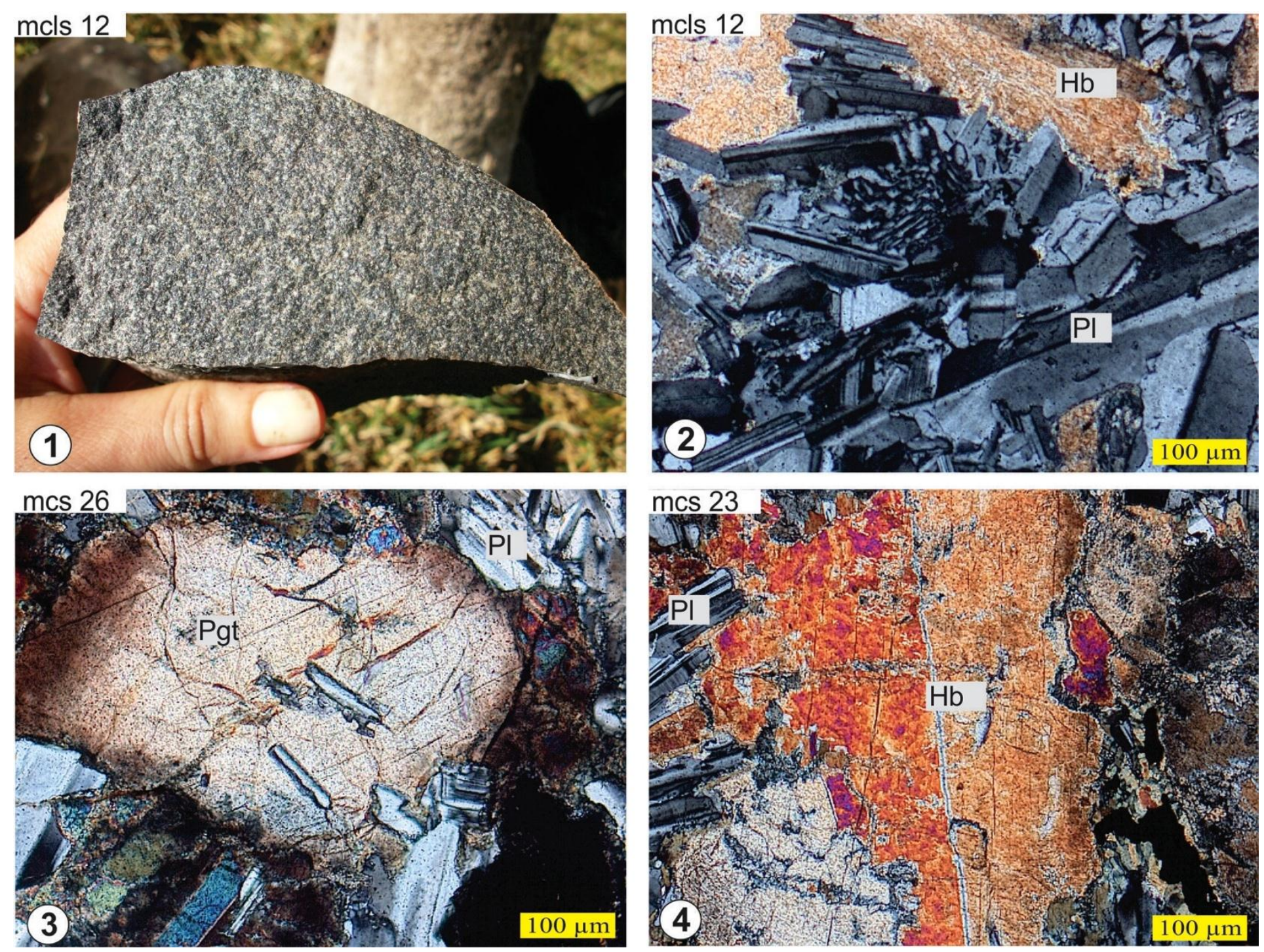

Figura 31. (1) Aspecto macroscópico do gabro, representado por rocha mesocrática, grossa e isotrópica; (2) cristais de hornblenda intersticiais e plagioclásio ripiforme em gabro; (3) cristal de clinopiroxênio com baixa birrefringência (piogenita); (4) cristal de hornblenda, associada ao clinopiroxênio (luz transmitida e polarizadores cruzados). Abreviações: $\mathrm{Hb}=$ hornblenda; Pgt $=$ piogenita; $\mathrm{Pl}$ = plagioclásio. 


\subsubsection{Granitoides diversos}

A caracterização petrográfica das rochas granitoides reconhecidas na área de estudo indica variação composicional significativa. As proporções relativas dos minerais obtidos a partir de análises modais semi-quantitativas quando plotadas no diagrama QAP (Streckeinsen 1976) permitem diferenciá-las e agrupá-las em unidades distintas, baseando-se nas expressivas variações texturais, nas razões entre plagioclásio/feldspato potássico e minerais máficos e acessórios, em rochas de composição granodiorítica a granítica. Adicionalmente, evidências de gnaissificação, fusão parcial e milonitização foram observadas em alguns desses litotipos.

Assim, os granitoides incluem biotita gnaisses de composição granítica e granodiorítica, variavelmente migmatizados e, localmente, milonitizados, além de biotita leucogranito, biotita monzogranito e hornblenda-biotita granito foliado.

\section{Biotita Gnaisse Granodiorítico}

O biotita gnaisse migmatítico localiza-se desde a porção central até o sudeste da área de estudo, em blocos rolados e grandes lajedos. Possui coloração cinza-esbranquiçada (Fig. 32-1) que grada para o rosa. Apresentam faixas ou bolsões quartzo-feldspáticos concordantes à foliação gnáissica da rocha, que podem representar leucossoma. O gnaisse apresenta granulação fina a média $(0,03-0,13 \mathrm{~mm})$, blastofenocristais (Fig. 32-2) e foliação bem desenvolvida, localmente milonítica (mcls 03).

Esse litotipo é constituído por plagioclásio (35 - 44\%), quartzo (25 - 35\%), microclínio $(7-15 \%)$, biotita $(10-18 \%)$, acessórios (titanita, zircão, opacos, muscovita) $(\operatorname{tr}-1 \%)$ e secundários (epidoto, sericita) $(\operatorname{tr}-6 \%)$. Quartzo microcristalino e cristais de biotita apresentam orientação preferencial.

Os cristais de plagioclásio são hipidiomórficos a xenomórficos, de granulação predominantemente fina $(0,03-0,08 \mathrm{~mm})$ e ocasionalmente média $(0,1-0,13 \mathrm{~mm}$; Fig. 32-4) e apresentam geminação do tipo albita. Orientam-se paralelamente ao quartzo e à biotita, e evidenciam recristalização discreta e encurvamento da geminação (Fig. 32-7), principalmente em amostras provenientes de áreas próximas a zonas de cisalhamento. A composição do plagioclásio estimada opticamente variou de oligoclásio cálcico a andesina sódica $\left(\mathrm{An}_{26-33}\right)$. O plagioclásio possui inclusão de quartzo, biotita e apatita. A sericitização é bem marcante, localizando-se preferencialmente nas porções centrais dos cristais, por vezes substituindo completamente o plagioclásio.

Os cristais de quartzo ocorrem como agregados com textura granoblástica, com leve extinção ondulante, geralmente como subgrãoes nas bordas de cristais de maiores dimensões. 
A fração fina de 0,03 - 0,06 mm apresenta extinção ondulante leve a moderada e ocorre inclusos nos cristais de plagioclásio. No contato desse com o feldspato potássico, o quartzo apresenta forma vermicular.

O microclínio apresenta granulação fina (0,02 - 0,08 mm; Fig. 32-5) ou ocorre como blastomegacristais $(0,1-0,13 \mathrm{~mm})$ com inclusões de quartzo e plagioclásio (Fig. 32-3). Feldspato com textura granofírica também ocorre intersticialmente nas junções entre microclínio, quartzo e o plagioclásio, e associa-se quartzo vermicular, indicando o início de processos de fusão parcial. Exibem textura poiquilítica, definida pela inclusão de cristais de biotita, quartzo e apatita em cristais médios de plagioclásio.

Os cristais de biotita são finos $(0,02-0,08 \mathrm{~mm})$, apresentam pleocroísmo variando do amarelo-claro ao verde e orientam-se concordantemente à foliação gnáissica. É possível observar pseudomorfos de biotita, substituídos por cristais de clorita. Titanita, zircão, opacos e muscovita (Fig. 32-8) também foram reconhecidas nesse litotipo.

A amostra mcls 03 possui mineralogia semelhante à das demais amostras dessa unidade, porém apresenta cisalhamento mais intenso e menor contéudo de quartzo. 

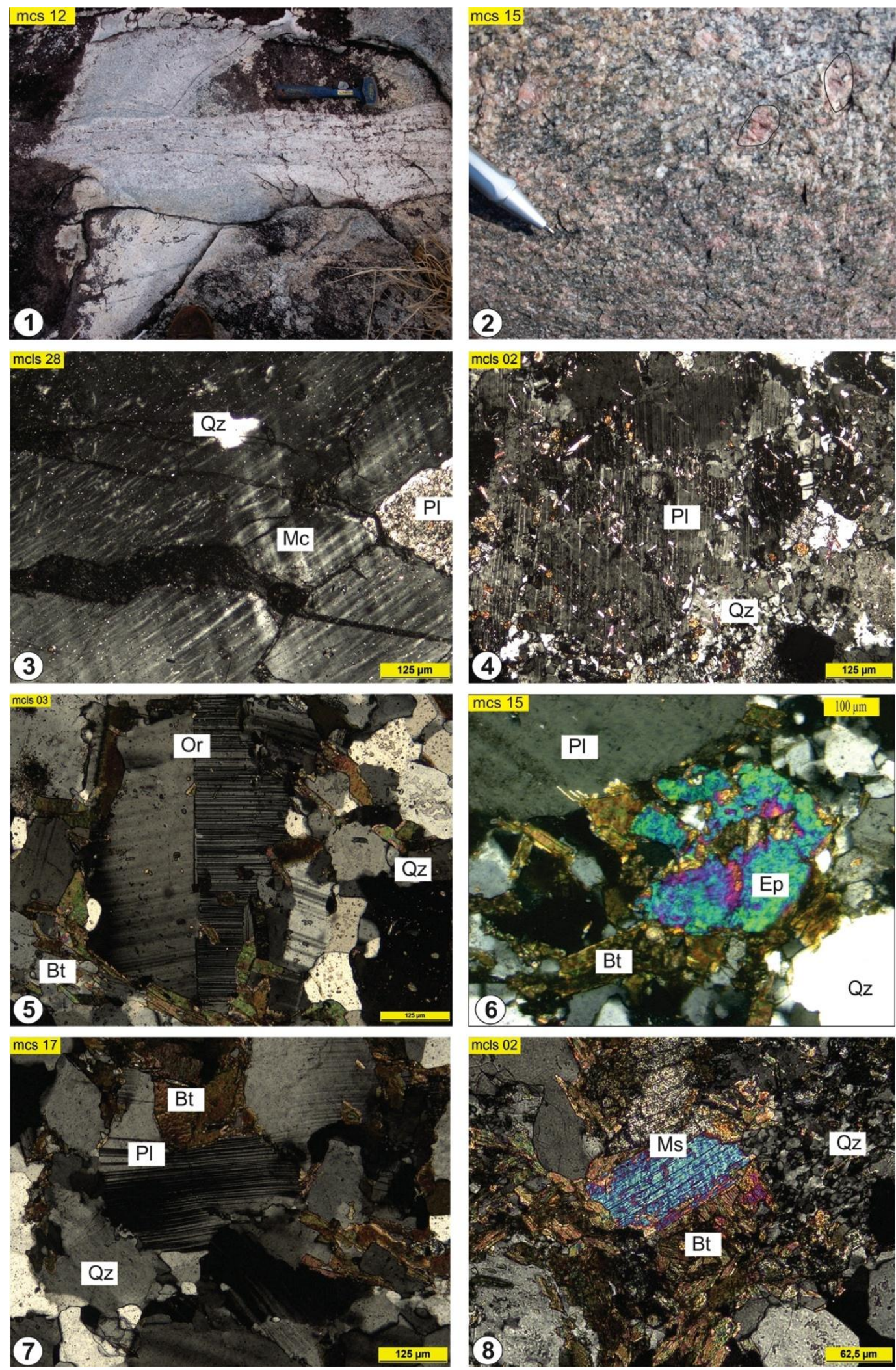

Figura 32. (1) Afloramento in situ do Biotita Gnaisse Granodiorítico, localmente migmatítico, no qual o bandamento composicional é bem evidente; (2) amostra macroscópica mostrando os megacristais de microclínio; (3) cristal de microclínio com inclusão de quartzo e plagioclásio; (4) megacristal de plagioclásio, cujas fraturas foram preenchidas por quartzo recristalizado; (5) cristal de ortoclásio com inclusão de quartzo; (6) cristais de epidoto em associação com a biotita; (7) cristal de plagioclásio com encurvamento dos planos da geminação e (8) muscovita em associação com a biotita (luz transmitida e polarizadores cruzados). Abreviações: $\mathrm{Bt}=$ biotita; $\mathrm{Ep}=$ epidoto $; \mathrm{Mc}=$ microclínio; $\mathrm{Ms}=$ muscovita $\mathrm{Pl}=$ Plagioclásio; $\mathrm{Or}=$ ortoclásio; $\mathrm{Qz}=$ quartzo 


\section{Metatexito estromático}

Essa unidade corresponde a migmatito com separação nítida de leucossoma granítico e mesossma com estrutura gnaíssica (Fig. 33-1), correspondendo, segundo Mehnert (1968) à metatexito estromático, localmente com estrutura dobrada.

O mesossoma é representado por biotita gnaisse granodiorítico de cor cinza esbranquiçada, com granulação fina $(0,04-0,09 \mathrm{~mm})$ a média $(0,1-0,15 \mathrm{~mm})$, constituído por plagioclásio (40\%), quartzo (34\%), feldspato potássico (10\%), biotita (10\%), hornblenda (2\%) e acessórios (epidoto, clinopiroxênio, titanita, apatita, clinozoisita e allanita) (3\%). O leucossoma apresenta composição quartzo-feldspática e, comumente, apresenta em seus limites filmes ricos em biotita, que correspondem ao melanossoma. Textura simplectítica caracterizada por intercrescimentos de biotita, anfibólio, epidoto e clinopiroxênio foram caracterizadas nas porções do mesossom e do melanossoma.

No mesossoma, o quartzo ocorre como cristais anédricos de granulação fina com extinção ondulante, enquanto o microclínio apresenta geminação em grade bem definida em cristais de granulação fina. O plagioclásio apresenta planos da geminação pouco definidos, e apresenta-se comumente sericitizado (Fig. 33-6), apresentando inclusão de quartzo arrendondado e cristais subehudrais de epidoto. Textura mimerquítica é reconhecida nos contatos entre quartzo e plagioclásio.

A biotita possui coloração verde e substitui os cristais de anfibólio, intercrescidos ao quartzo (Fig. 33-5). Os cristais de epidoto e/ou clinozoisita apresentam textura simplectítica, nas quais o quartzo vermicular ocorre como finas inclusões no epidoto (Fig. 33-3). O diopsídio exibe alta birrefringência, é subeuhdral e também apresenta textura simplectítica, devido à presença de finas inclusões irregulares de quartzo (Fig. 33-2). Observa-se em uma única secção, simplectitos com a hornblenda (que grada para biotita), com o epidoto e com o clinopiroxênio (Fig. 33-5). Magnetita (Fig. 33-7), titanita euhédrica, associada ou não com a biotita, apatita inclusa na biotita, zircão, clinozoisita e allanita Também foram reconhecidos nesse litotipo.

Mesossoma representado por biotita granodiorito gnaisse (mcls 26), sem hornblenda e diopsídio, também é reconhecido em afloramento de migmatito. Apresenta foliação gnáissica (Fig. 34-1 e 2) e textura simplectítica entre epidoto e quartzo. Mineralogicamente, são formadas por plagioclásio (42\%), quartzo (37\%), feldspato potássico (10\%), biotita (10\%), acessórios (epidoto e titanita) (6\%).

O quartzo constitui "fitas" de granulação muito fina, marcando nitidamente zonas de cristais cominuídos e cristais com forte extinção ondulante, por vezes formando subgrãos 
(Fig. 34-4). Os cristais de plagioclásio variam de granulação, sendo finos a médios $(0,03$ $0,15 \mathrm{~mm}$ ). Os maiores presentam inclusão de quartzo arrendondado e, localmente, apresentam zoneamento óptico e planos da geminação encurvados, além de extinção ondulante (Fig. 343), com composição variável entre $\mathrm{An}_{12}$ e $\mathrm{An}_{21}$.

O microclínio ocorre como cristais finos a médios $(0,03-0,06 \mathrm{~mm})$, intersticialmente na matriz e exibe maclamento difuso e pertitas. Os cristais de biotita são finos, subeuhédricos, com pleocroísmo variando de verde a amarelo claro (Figura 34-6). Ocorre geralmente nas bordas dos cristais médios de plagioclásio, juntamente com os minerais opacos e é substituído por clorita nos planos de clivagem. Epidoto subeuhdral a euhedral, com textura simplectítica com o quartzo (Fig. 34-5), além de titanita euhédrica (Fig. 34-6) também são observados. 

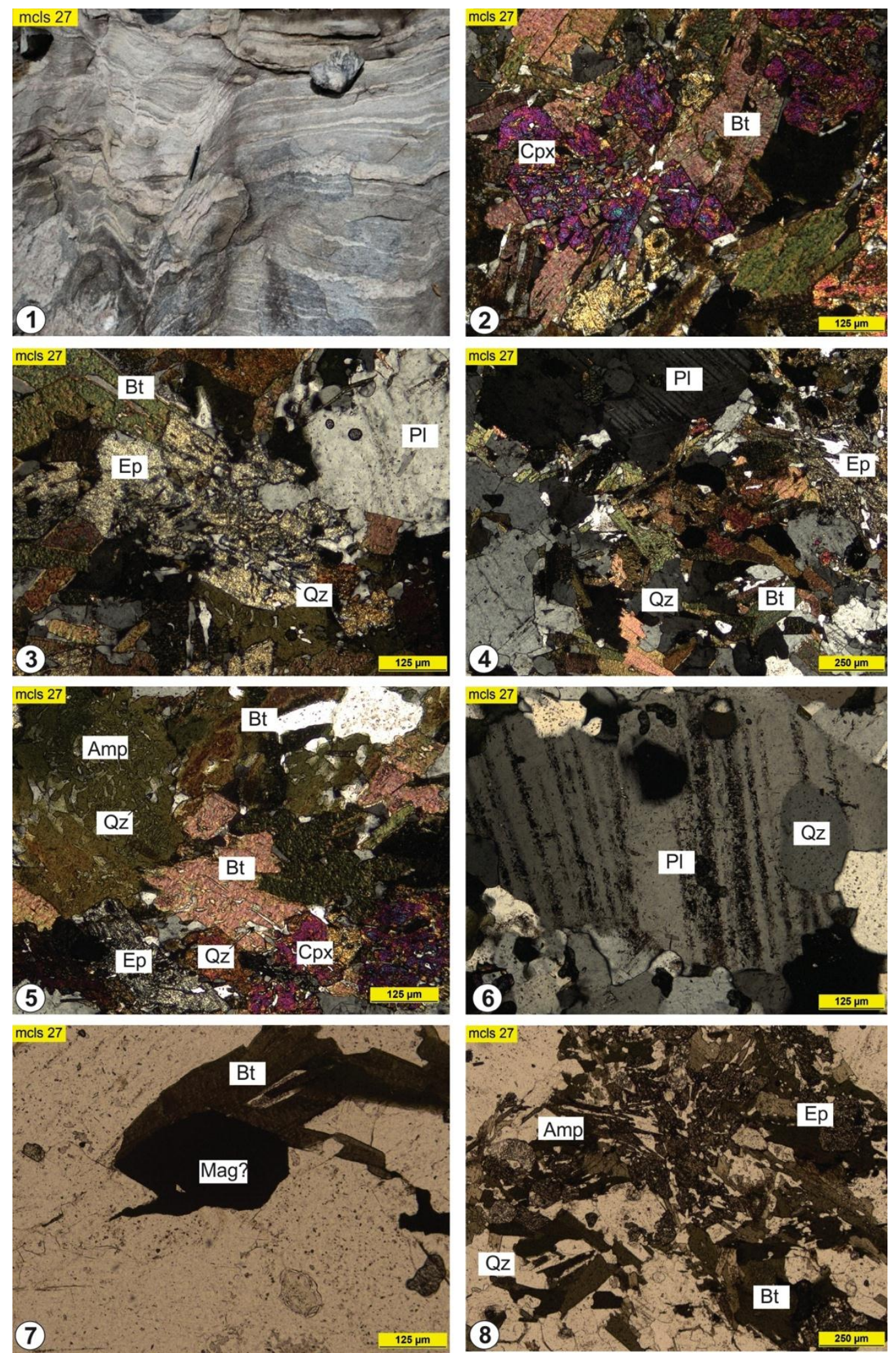

Figura 33. (1) Modo de ocorrência em lagedo de migmatito metatexítico estromático e dobrado; (2) mesossoma com diopsídio com textura simplectítica, com inclusões vermiculares de quartzo; (3) epidoto e quartzo com textura simplectítica; (4) aspecto geral do mesossoma, com cristais de plagioclásio, quartzo, biotita e epidoto; (5) textura simplectítica formada por anfibólio, epidoto e clinopiroxênio com inclusões de quartzo, sendo que a biotita substitui o anfibólio; (6) cristal de plagioclásio geminado com sericitização seletiva e inclusão de quartzo; (7) associação entre biotita e opacos (magnetita?) e (8) associação de biotita, anfibólio e epidoto. Fotomicrografias de 37-2 a 37-6 foram feitas a luz transmitida e polarizadores cruzados; fotos 37-7 e 37-8 sob luz transmitida e polarizadores descruzados. Abreviações: Amp = anfibólio; $\mathrm{Bt}=$ biotita; $\mathrm{Cpx}=$ clinopiroxênio; Ep = epidoto; Mag = magnetita; Pl = Plagioclásio; $\mathrm{Qz}=$ quartzo. 

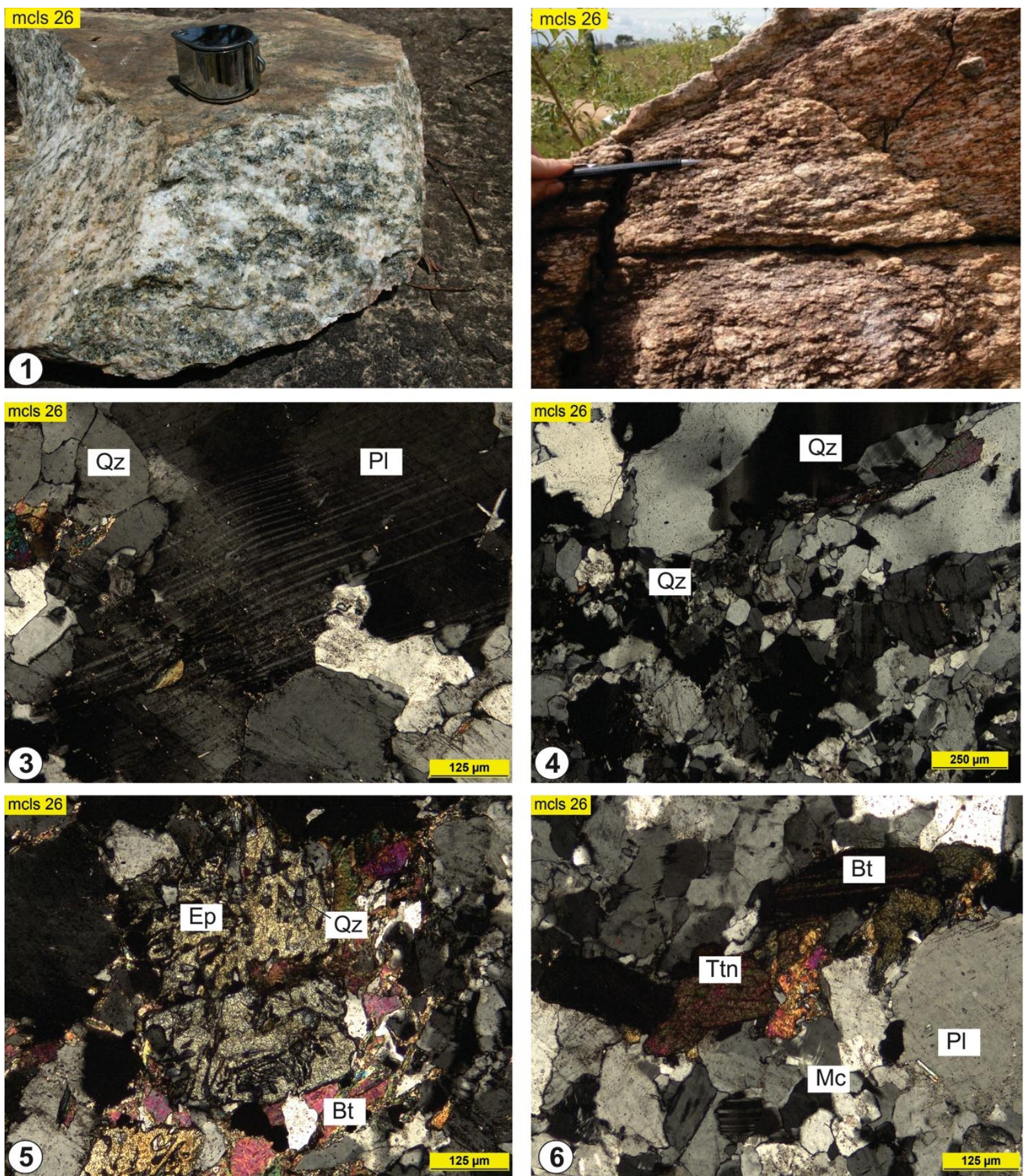

Figura 34. (1) Detalhe do biotita granodiorito gnaisse em amostra de mão; (2) detalhe da foliação anastomosada, milonítica, e porfiroclastos de plagioclásio; (3) detalhe do encurvamento dos planos de geminação do plagioclásio; (4) quartzo recristalizado, em subgrãos e com extinção fortemente ondulante; (5) clinozoisita com textura simplectítica e (8) cristais de titanita em associação com biotita (luz transmitida e polarizadores cruzados). Abreviações: $\mathrm{Bt}=$ biotita $; \mathrm{Ep}=$ epidoto; $\mathrm{Mc}=$ microclínio; $\mathrm{Pl}=$ plagioclásio; $\mathrm{Qz}=$ quartzo; $\mathrm{Ttn}=$ titanita. 


\section{Gnaisse granodiorítico milonitizado}

Gnaisse granodiorítico milonitizado ocorre no noroeste da área de estudo, em contato tectônico com as rochas metaultramáficas do Grupo Sapucaia (Fig. 13). Apresenta coloração cinza escura, granulação fina a média, foliação gnáissica $(\mathrm{Sn})$ dobrada e forte foliação milonítica (Fig. 35-1 e 2). Veios de quartzo dobrados acompanham a estruturação geral da rocha e apresentam por vezes flancos rompidos. Enclaves máficos são reconhecidos ao longo da foliação gnássica.

Mineralogicamente o gnaisse é composto por quartzo (25\%), plagioclásio (35\%), ortoclásio (18\%), biotita (19\%) e acessórios (epidoto e allanita) (3\%).

Os cristais de quartzo são finos, com forte extinção ondulante, com contatos retos ou serrilhados e formam "fitas" intercaladas aos microdomínios com predominância de biotita (Fig. 35-3) e, por vezes, ocorrem inclusos nos cristais médios de plagioclásio.

O plagioclásio possui granulação fina, exceto quando ocorre como porfiroclastos com geminação apertada (Fig. 35-4), pouco desenvolvida e com inclusão de quartzo e cristais de epidoto.

A biotita é subeuhdral e apresenta coloração verde e pleocroísmo variando de verde claro ao verde escuro. Apresenta-se fortemente estirada e achatada, formando clusters em faixa contínuas (Fig. 35-3 e 6).

Cristais de epidoto subeuhedral a euhedral, com alta cor de interferência encontra-se ou não associados aos cristais de biotita. Cristais de allanita com borda de epidoto também ocorrem subordinadamente (Fig. 35-5). 

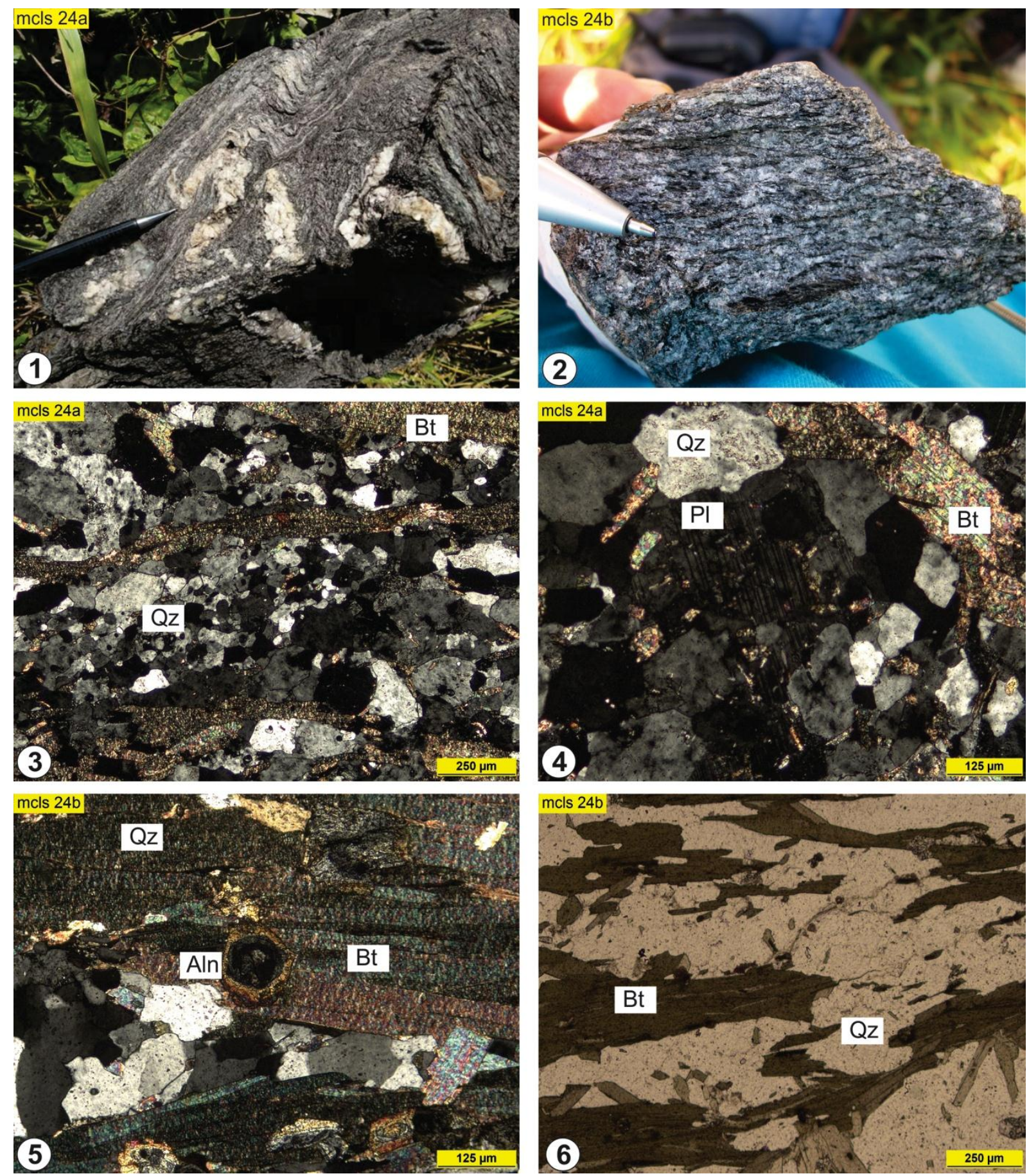

Figura 35. (1) Aspecto geral do gnaisse granodiorítico milonitizado com veios de quartzo, por vezes dobrados; (2) detalhe da foliação milonítica e dos porfiroclastos de plagioclásio; (3) faixa contínuas de biotita, cujo espaço microlítico é composto por quartzo recristalizado; (4) plagioclásio com geminação apertada, pouco desenvolvida; (5) cristal de allanita envolvido por epidoto, em associação com cristais de biotita e (6) fotomicrografia mostrando faixas de biotita. Fotomicrografias de 40-1 a 40-5 em luz transmitida e polarizadores cruzados e 40-6 com luz transmitida e polarizadores descruzados. Abreviações: $\mathrm{Aln}=$ allanita; $\mathrm{Bt}=$ biotita; $\mathrm{Pl}=$ plagioclásio; $\mathrm{Qz}=$ quartzo; $\mathrm{T}$ tn = titanita. 


\section{Hornblenda-Biotita Granito Foliado}

Hornblenda-biotita granito foliado concentra-se preferencialmente no sul da área, porém pontos isolados foram amostrados no nordeste e noroeste, onde afloram como blocos rolados (Fig. 36-1) e grandes matacões, em contato com uma zona de cisalhamento. Comumente, apresenta foliação milonítica, com enclaves máficos paralelizados à foliação e veios de quartzo sin-tectônicos em relação ao cisalhamento, localmente dobrados (Fig. 36-2).

O hornblenda-biotita granito apresenta coloração cinza com tons esbranquiçados a rosados, com megacristais de feldspato potássico e plagioclásio com minerais máficos e epidoto em suas bordas. Plagioclásio, quartzo, microclínio e ortoclásio são os minerais essenciais; biotita e hornblenda são minerais varietais; epidoto, titanita, apatita, opacos e zircão representam a fase acessória; epidoto, clorita e muscovita ocorrem como minerais secundários. Mineralogicamente são compostas por plagioclásio (28 - 35\%), quartzo (27 - 32 $\%)$, feldspato potássico $(15-25 \%)$, biotita $(9-14 \%)$, hornblenda $(1-5 \%)$, opacos $(\operatorname{tr}-1 \%)$, acessórios (tr - 2\%) e secundários (tr - 4\%).

Exibem granulação fina a média, onde a fração fina é representada por quartzo e microclínio recristalizados em agregados poligonais. Textura granofírica, pertitas e antipertitas são comuns. Os cristais de plagioclásio são hipidiomórficos a xenomórficos, de granulação fina $(0,01-0,08 \mathrm{~mm})$ a média $(0,1-0,15 \mathrm{~mm})$. Os megacristais de plagioclásio são contornados por quartzo microcristalino. Textura mimerquítica ocorre predominantemente entre os cristais médios, onde também há presença de bordas de dissolução com o quartzo microcristalino. Plagioclásio também encontra-se fraturado e preenchido com veios de quartzo e epidoto e, exibem inclusão de biotita e quartzo e alguns cristais apresentam saussuritização nas porções mais cálcicas.

Os grãos de quartzo são xenomórficos, finos $(0,03-0,06 \mathrm{~mm})$, ocorrendo como agregados, formando mosaicos, com contatos poligonais, em junção tríplice, com leve a forte extinção ondulante, normalmente bordejando cristais de maiores dimensões. Alguns grãos são policristalinos, fraturados e apresentam textura do tipo bulging. É comum quartzo incluso nos cristais de plagioclásio e/ou microclínio e preenchendo fraturas sob a forma microcristalina (Fig. 36-3).

Microclínio ocorre como: (i) cristais inequigranulares médios $(0,1-0,12 \mathrm{~mm})$, xenomórficos a hipidiomórficos de contornos irregulares e reentrantes entre si a retos com o plagioclásio. Apresentam inclusão de plagioclásio, biotita, apatita e quartzo. Alguns cristais apresentam-se fraturados e com bordas de dissolução em contato com o quartzo recristalizado. Textura granofírica, evidenciada por seu intercrescimento com o quarzto também é 
observada; (ii) cristais finos $(0,03-0,06 \mathrm{~mm})$, xenomórficos, intersticial, ocupando os espaços entre os cristais maiores de feldspatos. Em amostras cisalhadas, compõe o espaço microlítico da rocha. Ortoclásio hipidiomórfico, de granulação média apresenta ocorrência mais restrita que o microclínio (Fig. 36-8).

A biotita ocorre como cristais equigranulares finos $(0,03-0,07 \mathrm{~mm})$, com contornos regulares e contatos retos entre si e com os demais minerais. Apresentam localmente alteração para clorita nos planos de clivagem. Apresenta pleocroísmo forte, variando entre marrom esverdeado a amarelo pálido até marrom acastanhado, sempre com extinção reta picotada. Em porções mais cisalhadas, ocorre como cristais lamelares. Normalmente está associada a minerais opacos e ao epidoto (Fig. 36-7). Hornblenda também ocorre orientada segundo o plano da foliação e associa-se a cristais de epidoto (Fig. 36-5 e 6).

Minerais opacos finos $(0,02-0,05 \mathrm{~mm})$, com contornos regulares e contatos retos com a biotita (Fig. 36- 4 e 7) associa-se à titanita, assim como apatita (Fig. 36-7). Zircão ocorre sob a forma de cristais finos, inclusos na biotita, onde formam halos pleocróicos, enquanto allanita tem ocorrência mais restrita. Epidoto preenche fraturas no plagioclásio, e representa uma das fases associadas com saussuritização/descalcificação do plagioclásio. Adicionalmente, clorita substitui localmente a biotita. 

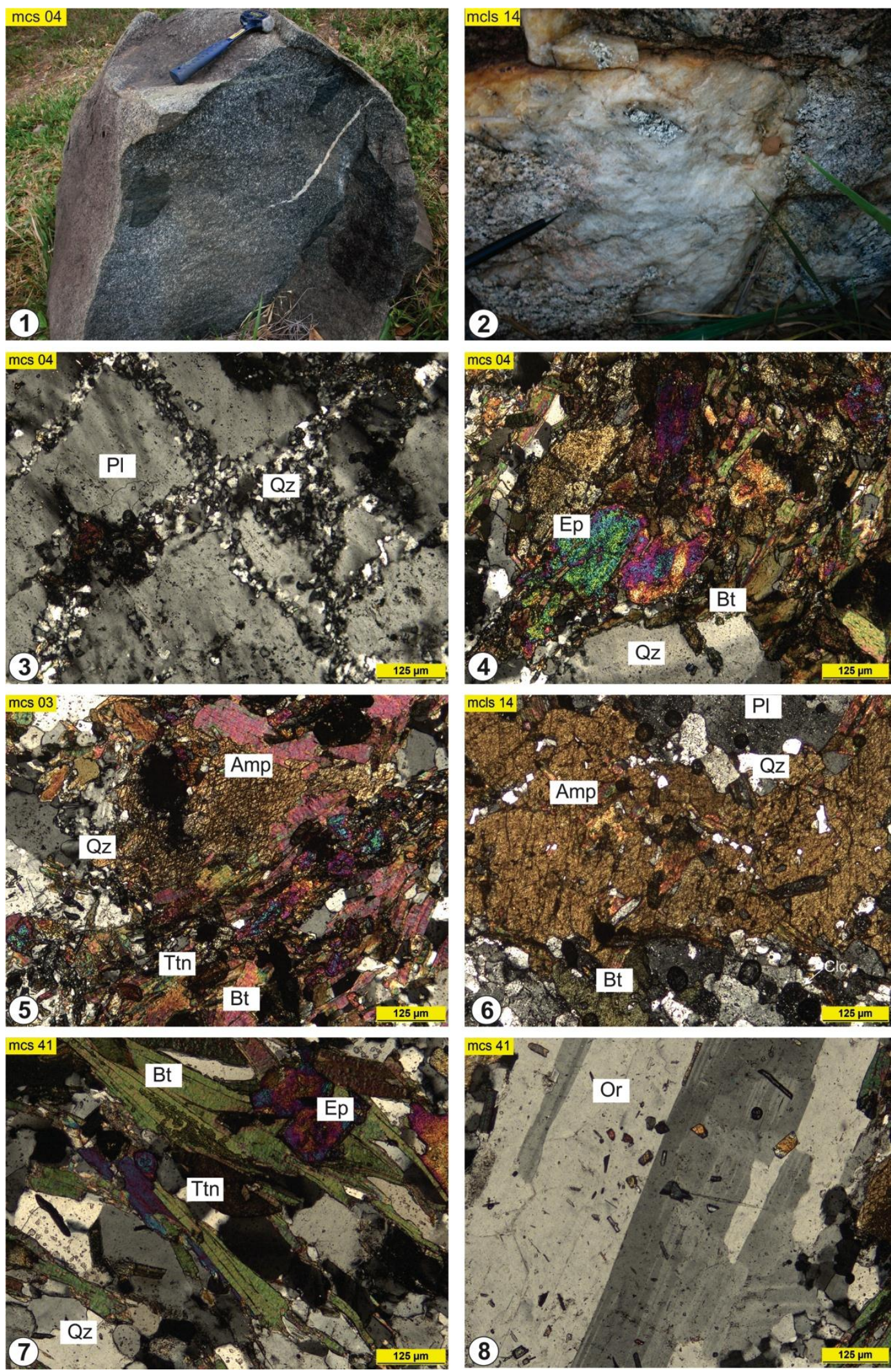

Figura 36. (1) Bloco rolado de hornblenda-biotita granito foliado, com enclaves de rocha máfica; (2) veios de quartzo em hornblenda-biotita granito foliado; (3) megacristal de plagioclásio, cujas fraturas estão preenchidas por quartzo recristalizado; (4) epidotoem fraturas; (5) hornblenda em associação com biotita e titanita; (6) cristais de hornblenda com inclusão de biotita e titanita; (7) biotita orientada no plano da foliação, em associação com epidoto e titanita e (8) megacristal de ortoclásio com pequenas inclusões de epidoto. Fotomicrografias feitas sob luz transmitida e polarizadores cruzados. Abreviações: Amp = anfibólio; $\mathrm{Bt}=$ biotita; $\mathrm{Ep}=$ epidoto; $\mathrm{Pl}=$ Plagioclásio; Or = ortoclásio; Ttn = titanita; $\mathrm{Qz}=$ quartzo. 


\section{Biotita Leucogranito}

Biotita leucogranito é aflorante apenas na porção sudeste da área como blocos rolados ou pequenos lajedos, em um ponto isolado na região centro-oeste da área. Em geral, corresponde a rocha de composição granodiorítica a monzogranítica, hololeucocrática (M 4\%) de coloração branco-acinzentada a rosa-acinzentada, onde a biotita é o principal mineral ferromagnesiano. Esse litotipo apresenta textura fanerítica média e aspecto anisotrópico variável, evidenciado principalmente pelo alinhamento dos minerais máficos e menos frequentemente por foliação milonítica em rochas próximas à zona de cisalhamento (Fig. 361). É composto por quartzo microcristalino (30 - 37\%), plagioclásio (31 - 39\%), feldspato potássico $(20-28 \%)$, biotita $(3-5 \%)$, acessórios $(\operatorname{tr}-1 \%)$ e secundários $(\operatorname{tr}-2 \%)$.

Textura granofírica no contato entre o microclínio e quartzo vermicular, exsoluções de pertitas, mimerquitas e textura poiquilítica, definida pelas inclusões de cristais de biotita e quartzo em megacristais de plagioclásio e microclínio são carcterísticas desse litotipo.

Os cristais de plagioclásio são hipidiomórficos a xenomórficos, finos $(0,03-0,08$ $\mathrm{mm}$ ) e médios (0,1 - 0,13 mm; Fig. 36-3). Plagioclásio fino ocorre na matriz e os cristais médios são bordejados por quartzo microcristalino, apresentam inclusão de quartzo, geminação por vezes apertada, textura mimerquítica e dissolução em suas bordas quando em contato com o quartzo microcristalino. Localmente, alguns cristais apresentam extinção ondulante.

O quartzo é granular, microcristalino, xenomórfico e apresenta forte extinção ondulante. Por vezes, preenche fraturas (Fig. 37-2) e ocorre inclusos nos cristais de plagioclásio. Apresenta forma vermicular em contato com feldspato potássico.

Os cristais de microclínio são xenomórficos a subautomórficos, de granulação fina $(0,02-0,08 \mathrm{~mm})$ ou ocorrem como megacristais, com textura granofírica e formação de pertitas em filme, com inclusão de quartzo, biotita e plagioclásio (Fig. 37-5 e 6). Cristais de ortoclásio possuem granulação média, bordas corroídas em contato com o quartzo e plagioclásio (Fig. 37-4). A biotita é fina $(0,02-0,05 \mathrm{~mm})$, apresenta pleocroísmo entre o amarelo e marrom e, localmente, é substituída por clorita e associa-se a cristais de epidoto (Fig. 37-7). Minerais opacos são raros, finos, xenomorfos e ocorrem geralmente preenchendo fraturas ou de forma disseminada (Fig. 37-8). Ocorrência de apatita, titanita e muscovita também foram observadas mais raramente. 

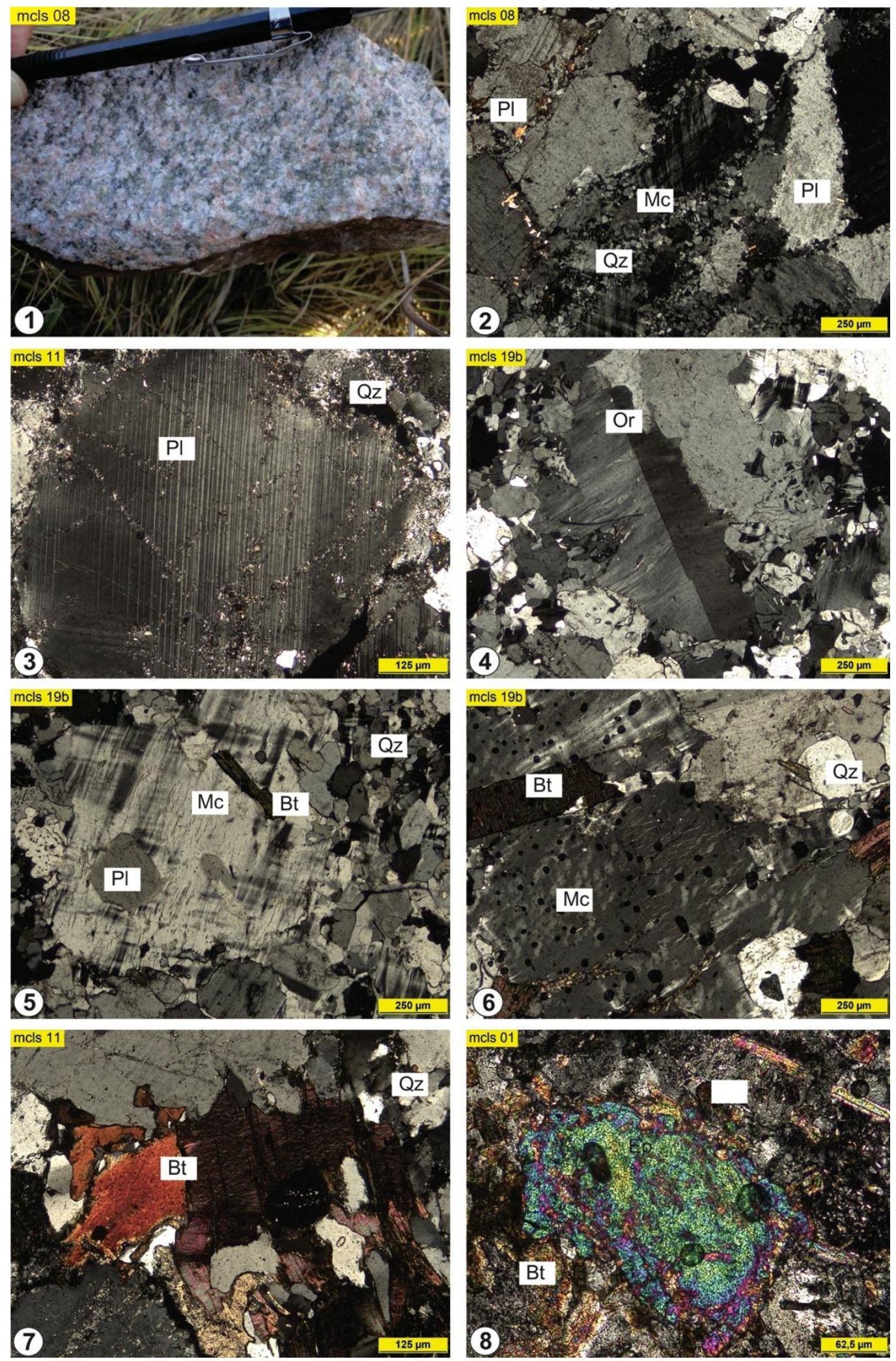

Figura 37. (1) Aspecto macroscópico do biotita leucogranito com textura fanerítica média e sutil alinhamento da biotita segundo uma orientação preferencial; (2) megacristais de microclínio e matriz com predominância de quartzo recristalizado; (3) megacristal de plagioclásio com geminação apertada, fraturas preenchidas por quartzo e bordas corroídas; (4) cristal de ortoclásio hipidiomórfico com pertitas, envolvido por mimerquitas; (5) microclínio com inclusão de plagioclásio e biotita; (6) microclínio com pertitas em filme; (7) biotita, que representa a principal fase ferromagnesiana do biotita leucogranodiorito a monzogranito e (8) epidoto em associação com biotita. Fotomicrografias sob luz transmitida e polarizadores cruzados. Abreviações: Bt $=$ biotita; $\mathrm{Ep}=$ epidoto; $\mathrm{Mc}=$ microclínio; $\mathrm{Pl}=$ Plagioclásio; $\mathrm{Or}=$ ortoclásio; $\mathrm{Mc}=$ microclínio; $\mathrm{Qz}=$ quartzo. 


\section{Biotita Monzogranito Milonitizado}

Biotita monzogranito milonitizado ocorre como blocos rolados, em diferentes regiões da área de estudo (mapa da Fig. 13), ao longo das zonas de cisalhamento que define o contato com as rochas do Grupo Sapucaia e o embasamento granito-gnáissico. Possui coloração rosada, hololeucocrática (máficos 5\%), forte foliação milonítica, injeção de veios pegmatíticos e porfiroclastos de feldspato potássico envoltos por uma matriz quartzofelspática (Fig. 38-1 a 3). Mineralogicamente são formadas por plagioclásio (28\%), quartzo (35\%), feldspato potássico (33\%), biotita (4\%) e acessórios (titanita e muscovita) (tr).

Os cristais de quartzo são granulares finos a muito finos, orientados conforme o plano da foliação, formando mosaicos poligonais, com extinção ondulante e, localmente, estão inclusos em cristais de feldspato potássico.

Os cristais de microclínio são: $(i)$ finos $(0,01-0,04 \mathrm{~mm})$, intersticiais e compõe a matriz juntamente com o quartzo recristalizado, apresentando geminação bem definida e localmente desenvolvimento de pertitas (Fig. 38-8); (ii) porfiroclastos (0,1 - 0,15 mm), envoltos pela matriz, muitas vezes com bordas corroídas em contato com o quartzo recristalizado (Fig. 38-4), geminação difusa e com inclusão de cristais de quartzo e pequenos cristais de epidoto subeuhedral.

O plagioclásio apresenta granulação fina e geminação pouco espaçada. A biotita ocorre como cristais lamelares, finos, orientados conforme a foliação milonítica e, geralmente, estão associados aos minerais opacos (Fig. 38-7). Esses opacos possuem hábito semelhante ao da magnetita, são subeuhedrais e de ocorrência restrita. Também ocorrem subordinadamente, titanita bem formada (Fig. 38-6) e muscovita (Fig. 38-5). 

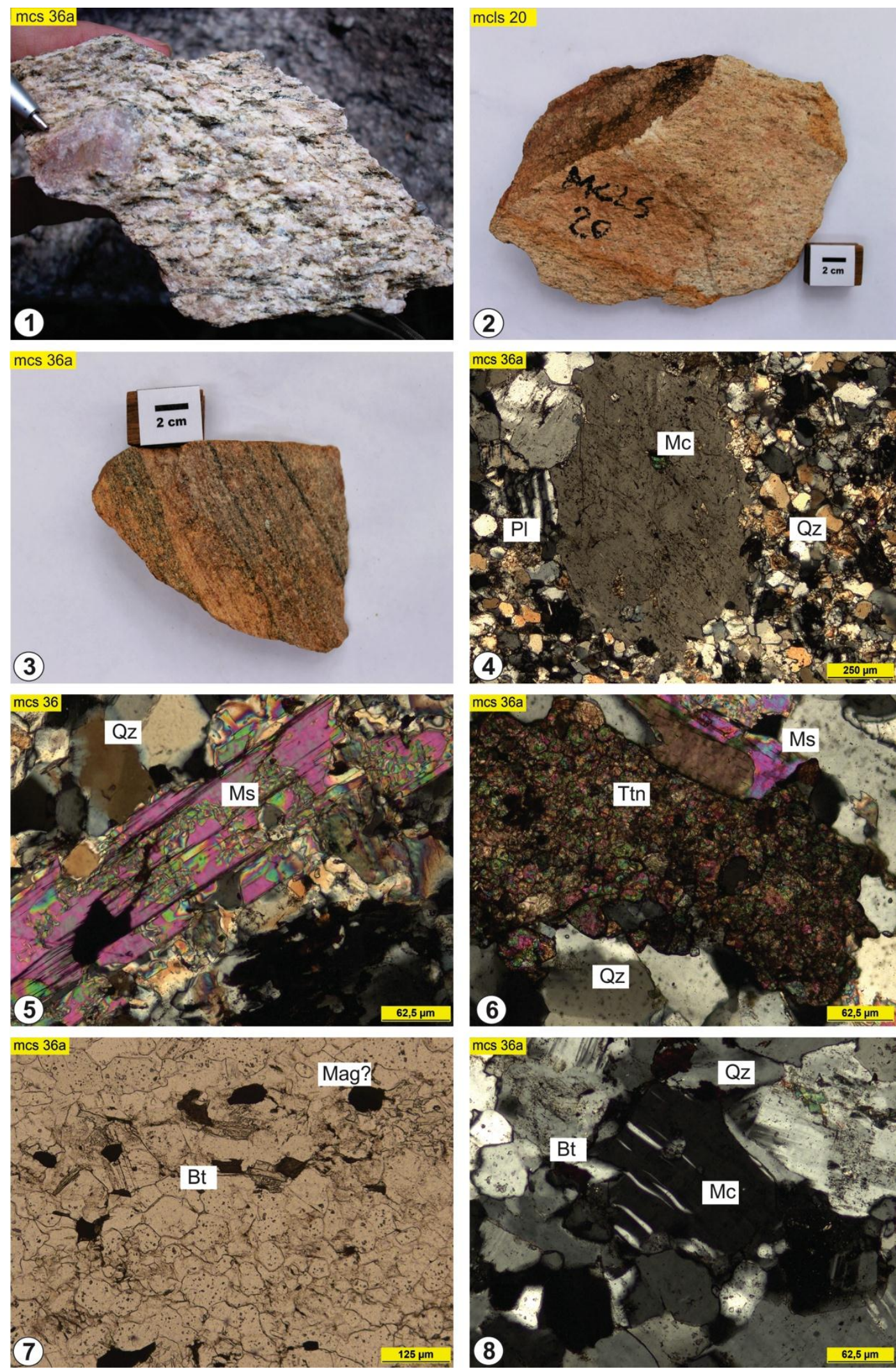

Figura 38. Aspecto do biotita monzogranito milonitizado: (1) porfiroclastos de feldspato potássico em biotita leucomonzogranito com foliação milonítica anastomosada; (2) e (3) detalhe da foliação milonítica bem desenvolvida e forte orientação da biotita em seus planos; (4) porfiroclasto de microclínio com inclusão de epidoto, envolto por quartzo recristalizado; (5) muscovita em associação com os raros cristais de opaco e biotita; (6) titanita em associação com biotita e muscovita; (7) fotomicrografia em luz transmitida com polarizadores descruzados evidenciando a pequena quantidade de biotita presente na rocha e (8) matriz quartzo-feldspática dessas rochas, com microclínio formando pertitas em filme. Abreviações: $\mathrm{Bt}=$ biotita; Mag = magnetita; $\mathrm{Mc}=$ microclínio; $\mathrm{Ms}=$ muscovita; $\mathrm{Pl}=$ plagioclásio; $\mathrm{Qz}=$ quartzo; $\mathrm{Ttn}=$ titanita.

Dissertação de Mestrado - IG-USP - Soraya Damasceno Sousa - 2014 


\subsection{CONSIDERAÇÕES SOBRE O METAMORFISMO}

Os estudos petrográficos das unidades metaultramáficas, máficas e metapelíticas possibilitaram o reconhecimento da foliação Sn-1, preservada, raramente, apenas como foliação interna em porfiroblastos (anfibólio ou granada), e fortemente transposta pela foliação Sn. Relações de blastese mineral com tais foliações permite algumas inferências relativas à evolução metamórfica nesses litotipos. $\mathrm{O}$ desenvolvimento da clivagem de crenulação $\mathrm{Sn+1}$ apenas localmente resultou em blastese mineral associada, sugerindo seu desenvolvimento em condições retrógradas.

\subsubsection{Unidades metaultramáficas}

Nas rochas metaultramáficas, a paragênese clorita-tremolita, é comumente formada a partir de protólitos lherzolíticos e/ou komatiíticos. Em protólitos dessa natureza, sua formação pode ser inferida a partir da mineralogia ígnea original, representada por clinopiroxênio e olivina, em condições que persistem nas fácies xisto verde a anfibolito. A presença de foliação interna nos porfiroblastos de tremolita, definida pela orientação de inclusões de opacos, discordante da $\mathrm{Sn}$, indica sua blastese anterior ao desenvolvimento dessa foliação.

Adicionalmente, magnetita fina em alguns dos porfiroblastos de tremolita e concentrase em planos cristalográficos, também pode indicar que a substituição do piroxênio ígneo pela tremolita, durante ou após o desenvolvimento da Sn-1, resultou em sobra de Fe, possibilitando a formação de magnetita associada a esse mineral.

Por sua vez, a substituição dos porfiroblastos de tremolita ao longo de suas bordas por antofilita evidencia a progressão do metamorfismo pós Sn-1 e durante o desenvolvimento da Sn. Ainda que a formação de antofilita a partir da quebra de talco seja indicativa de condições de fácies anfibolito, a associação de antofilita e minerais carbonáticos nos antofilita-cloritatremolita xistos sugere sua formação a partir da reação (1), que de acordo com Ford \& Skippen (1997), é dependente da $\mathrm{X}_{\mathrm{CO} 2}$ e pode ocorrer a partir da fácies dos xistos verdes:

\section{$\mathrm{Ca}_{2} \mathrm{Mg}_{5} \mathrm{Si}_{8} \mathrm{O}_{22}(\mathrm{OH})_{2}+4 \mathrm{Mg}\left(\mathrm{CO}_{3}\right) \Leftrightarrow 2 \mathrm{CaMg}\left(\mathrm{CO}_{3}\right)_{2}+\mathrm{Mg}_{7} \mathrm{Si}_{8} \mathrm{O}_{22}(\mathrm{OH})_{2}$ Tremolita magnesita dolomita antofilita}

Embora os cristais de antofilita não sejam reconhecidos especialmente nos domínios mais ricos em clorita, sua formação também pode ter sido resultante da reação que acompanha o enriquecimento em alumínio da Mg-clorita durante a progressão do metamorfismo, pela reação (2), sugerida por Szabó (1996): 


\section{$147 \mathrm{Mg}$-Clorita $[(\mathrm{x}) \mathrm{Al}=1,00]+40 \mathrm{SiO}_{2} \Leftrightarrow 140 \mathrm{Mg}$-Clorita $[(\mathrm{x}) \mathrm{Al}=1,05]+12$ Antofilita $+8 \mathrm{H}_{2} \mathrm{O}$

Adicionalmente, a presença de antofilita nos clorita-tremolita xistos pode também refletir processos metassomáticos, comuns na zona de reação entre rochas metaultramáficas e as rochas encaixantes. Nesse caso, sua formação a partir de anfibólios cálcicos pode ser relacionada à alteração hidrotermal envolvendo adição de $\mathrm{Mg}$ e perda de $\mathrm{Fe}$ e $\mathrm{Ca}$ (Deer et al. 1997).

A substituição de tremolita por cummingtonita ou magnesio-cummingtonita pode refletir processo metassomático análogo em condições compatíveis com as da fácies anfibolito. No greenstone belt de Agnew-Wiluna, cummingtonita também foi descrita em rochas compostas por clorita-tremolita, interpretadas como derivadas de derrames komatiíticos metamorfisados (Gole et al. 1987). Adicionalmente, magnesiocummingtonita em associação com tremolita e antofilita também foi reportada em rochas metaultramáficas em fácies anfibolito formadas a partir de protólitos duníticos e peridotíticos de Spruce Pine Mining District, Carolina do Norte, EUA (Swanson 2008).

O olivina-hercinita-clorita-(Mg)hornblenda xisto, por sua vez, apresenta forte estiramento da olivina, indicando deformação dúctil em elevadas condições de temperatura. A associação de olivina e hercinita aponta para a reação (3), desenvolvida em condições de pico metamórfico na fácies anfibolito superior, transicional para fácies granulito, prévia a concomitante com o desenvolvimento da foliação milonítica, que resultou em forte estiramento da olivina:

\section{Clorita $(\mathrm{Chl}) \Leftrightarrow$ Forsterita (Fo) + Enstatita (En) + Espenélio (Spl) + $\mathrm{H}_{2} \mathrm{O}$ (3)}

O limite superior de estabilidade da clorita em rochas metaultramáficas naturais, contudo, pode ocorrer em temperaturas menores que as esperadas para o sistema MASH puro, porque components adicionais $(\mathrm{Fe}, \mathrm{Cr}$ e $\mathrm{Ni}$ ) são fortemente particionados no espenélio. Assim, a coexistência de espinélio hercinítico e Mg-clorita pode ocorrer já em condições de fácies anfibólio a temperaturas $<700{ }^{\circ} \mathrm{C}$ (Bucher \& Grapes, 2011). Nessas condições de fácies anfibolito, o anfibólio torna-se mais enriquecido em alumínio, adquirindo composição de Mg-hornblenda. Nos litotipos estudados, durante o retrometamorfismo, raras relíquias de enstatita são observadas envolvidas pela Mg-hornblenda. Adicionalmente, Mg-clorita e serpentina formaram-se devido às reações retrógadas. 
Dessa forma, o metamorfismo retrógrado estabilizou assembleias com serpentina, talco, carbonatos e clorita nos litotipos metaultramáficos, que comumente substituem as paragêneses formadas durante o desenvolvimento da foliação $\mathrm{Sn}$.

Os serpentinitos apresentam relíquias de texturas ígneas sugestivas de protólitos cumuláticos. Os pseudomorfos de olivina são constituídos predominantemente por lizardita, que pode ter sido formado pela reação (4), proposta por Evans (2004), resultando em sua comum associação com a magnetita.

\section{MgFe-olivina $+\mathrm{H}_{2} \mathrm{O} \Leftrightarrow$ MgFe-serpentina + MgFe-brucita + magnetita $+\mathrm{H}_{2}(\mathrm{aq})$}

A formação de lizardita com textura em rede por essa reação é controlada pela razão fluido/rocha, atividade de sílica, fugacidade de oxigênio e pH (Evans, 2004) e, comumente, resulta de hidrotermalismo de fundo oceânico ou retrometamorfismo ao longo de zonas de cisalhamento com influxo de fluidos. Adicionalmente, em baixo grau metamórfico (fácies dos xistos verdes inferior, $\mathrm{P}<4 \mathrm{kbar} ; \mathrm{T} \sim 200-300{ }^{\circ} \mathrm{C}$ ), lizardita é a fase dominante, enquanto antigorita é ausente (Evans 2004). Contudo, de acordo com Schwartz et al. 2013, lizardita e antigorita poderiam coexistir entre 320 e $390{ }^{\circ} \mathrm{C}$ em altas pressões (acima de $9 \mathrm{kbar}$ ).

Em terrenos polideformados, entretanto, a textura em rede pode ser preservada em todas as condições de pico metamórfico, embora antigorita substitua, parcial a totalmente, a lizardita (Schwartz et al. 2013) durante o metamorfismo progressivo. Adicionalmente, a lizardita também pode ser resultante do reequilíbrio metamórfico na trajetória retrometamórfica, na qual a antigorita torna-se instável. Dessa forma, a paragênese com lizardita possivelmente revela condições em fácies dos xistos verdes inferior que prevaleceram durante o metamorfismo retrógrado.

\subsubsection{Evidências de metassomatismo nos litotipos metaultramáficos}

Gradientes de potencial químico entre rochas ultramáficas e félsicas, usualmente saturadas em quartzo, resulta na formação de zonas metassomáticas extensas, que tipicamente apresentam zonamento de sequências blackwall, monominerálicas. Em condições de metamorfismo de baixo grau, as zonas comumente incluem rochas com predominância de talco, actinolita, clorita e biotita, sendo as últimas mais próximas à interface entre os diferentes litotipos (Winter 2010, Bucher \& Grape 2011). Corpos de rochas metaultramáficas de pequenas dimensões podem ser completamente modificados.

A presença de litotipos quase monominerálicos, como os talco xistos também é comumente atribuída a processos retrometamórficos, principalmente aos associados a zonas de cisalhamento com influxo de fluidos. Contudo, nesse litotipo a paragênese talco-clinocloro 
é formada durante o desenvolvimento da foliação Sn, comumente transposta pela clivagem de crenulação, na qual talco e magnetita também são reconhecidos.

A associação de talco-Mg clorita é compatível com a esperada para o sistema MASH $\left(\mathrm{MgO}-\mathrm{Al}_{2} \mathrm{O}_{3}-\mathrm{SiO}_{2}-\mathrm{H}_{2} \mathrm{O}\right)$, no qual alumínio é incorporado exclusivamente na clorita magnesiana em temperaturas mais baixas (Bucher \& Grapes, 2011). Nesse sistema, o talco é estável desde condições na fácies xisto verde até fácies anfibolito, enquanto o limite de estabilidade da clorita magnesiana em sistemas naturais com componentes extras, especialmente $\mathrm{Fe}, \mathrm{Cr}$ e $\mathrm{Ni}$, não excede $700{ }^{\circ} \mathrm{C}$, a pressões baixas e intermediárias. A predominância de talco nesse litotipo pode ser resultante de metassomatismo de serpentinitos pela reação (5), acompanhada por introdução de fluidos, proposta por Bucher-Nurminen (1988):

$$
\text { Antigorita }+ \text { Quartzo }+\mathrm{H}_{2} \mathrm{O} \Leftrightarrow \text { Talco }
$$

Processos metassomáticos também podem ser atribuídos a formação dos cloritaactinolita xistos e clorititos, que podem representar zonas intermediárias e proximais de zonas com alteração do tipo blackwall. As associações dos black wall tanto a actinolita como a clorita acompanham o desenvolvimento da foliação $\mathrm{Sn}$, refletindo sua formação durante o metamorfismo, porém tais rochas comumente apresentam foliação milonítica bem desenvolvida.

Em todos esses litotipos, geracões tardias de clorita e talco também formaram-se durante o retrometamorfismo.

\subsubsection{Unidades metamáficas}

Nos metabasitos, a paragênese Mg-hornblenda I - quartzo - plagioclásio-opacos, sin a pós-cinemática em relação à Sn-1, e a paragênese Mg-hornblenda II - quartzo - oligoclásioandesina - titanita - apatita - allanita desenvolvida durante a Sn, sugerem condições próximas de metamorfismo em fácies anfibolito inferior.

Nessas condições, acima de $600{ }^{\circ} \mathrm{C}$, clorita e epidoto são consumidos na reação que resulta na formação de hornblenda e anortita, segundo a reação (6), descrita por Bucher \& Frey (1994):

$$
\begin{gathered}
\text { Clorita }+ \text { Zoizita }+ \text { Quartzo } \Leftrightarrow \text { Hornblenda }+ \text { Anortita }+\mathbf{H}_{2} \mathbf{O}(6) \\
\begin{array}{c}
\mathbf{C h l}+\mathbf{1 8 Z o}+\mathbf{2 1 Q t z o} \Leftrightarrow 5 \mathrm{Ts}-\mathbf{H b l}+\mathbf{2 6} \mathrm{An}+\mathbf{2 0 \mathbf { H } _ { 2 } \mathrm { O }} \\
T s=\text { componente tchermakítico do anfibólio }
\end{array}
\end{gathered}
$$


Por sua vez, a titanita associada à paragênese relacionada ao desenvolvimento da $\mathrm{Sn}$, pode ser considerada um mineral índice da fácies anfibolito inferior (Spear et al. 1993), uma vez que em condições de fácies anfibolito superior a titanita é consumida, originando hornblenda com maior conteúdo de Ti associada à ilmenita.

\subsubsection{Unidades metapelítica}

A associação mineral reconhecida nos muscovita-biotita xistos (biotita-muscovitaquartzo-plagioclásio \pm almandina \pm ilmenita \pm hematita) é típica das fácies dos xistos verdes, sendo estável até condições de fácies anfibolito superior, transicional para fácies granulito, nas quais ocorre a quebra da muscovita.

A blastese de almandina foi sin- a tardi tectônica em relação ao desenvolvimento da Sn-1 e anterior à Sn, evidenciando condições mínimas de metamorfismo na fácies dos xistos verdes superior, na zona da granada, a partir das reações (7) ou (8):

$$
\begin{gathered}
\text { Clorita }+ \text { Quartzo } \Leftrightarrow \text { Almandina }+\mathrm{H}_{2} \mathrm{O} \\
\text { Clorita }+ \text { Muscovita }+ \text { Quartzo } \Leftrightarrow \text { Almandina }+ \text { Biotita }+\mathrm{H}_{2} \mathrm{O}
\end{gathered}
$$

A almandina foi estirada durante o desenvolvimento da $\mathrm{Sn}$, ainda em condições de fácies xisto verde. Nesses litotipos, a clorita é principalmente retrógrada e formou-se a partir da biotita e granada, parcialmente consumidas, possivelmente pela reação (8). 


\section{GEOQUÍMICA}

Para uma melhor caracterização das rochas da sequência greenstone belt do Grupo Sapucaia e rochas associadas, a geoquímica teve um papel importante, pois auxiliou na compreensão dos processos magmáticos e das alterações metassomáticas que modificaram essas rochas.

Nas rochas metaultramáficas estudadas, relictos de texturas ou minerais magmáticos foram muito raramente observados, o que exigiu cuidado adicional para a caracterização dos litotipos mais preservados dos processos pós-magmáticos. As paragêneses metamórficas, por sua vez, refletem em grau variável processos metassomáticos que possibilitaram reações metamórficas comuns nos sistemas químicos estudados (por exemplo, serpentinizacão de olivina e formação de talco a partir da introdução de $\mathrm{SiO}_{2}$ ), durante o metamorfismo regional. Não podem ser também desconsideradas mudanças nas composições químicas dos protólitos prévias ao metamorfismo regional, como as típicas de ambiente de fundo oceânico (espilitização, keratofirização, epidotização e silicificação). Adicionalmente, processos metassomáticos concomitantes ao metamorfismo regional e à instalação de zonas de cisalhamento decorrente do gradiente de potencial químico entre rochas metaultramáficas e os granitoides presentes na área, também podem ter resultado em transformações químicas e mineralógicas registradas nas rochas analisadas, como evidenciado por rochas monominerálicas, como os clorititos que assemelham-se a blackwall.

\subsection{GEOQUÍMICA DAS ROCHAS METAULTRAMÁFICAS E METAMÁFICAS}

\subsubsection{Classificação}

Com base nos estudos petrográficos, os litotipos ultramáficos analisados foram agrupados em: a) Mg-cummingtonita e/ou antofilita xistos com quantidades variáveis de tremolita, talco, clorita e magnetita (antofilita-Mg-cummingtonita xistos; $n=3$ ); b) cloritatremolita xistos com antofilita, talco e carbonatos $(n=5)$; c) clorita-actinolita xistos $(n=3)$; e d) cloritito $(n=1)$. Os metabasitos $(n=5)$ são representados por amostras de Mg-hornblenda anfibolito foliado e hornblenda anfibolito, além de metagabros. As composições químicas médias para esses litotipos são apresentadas na Tabela 3 e as análises relativas a cada amostra no Apêndice 10.

Em relação aos elementos maiores e traços, os antofilita-Mg-cummingtonita xistos diferenciam-se dos demais litotipos metaultramáficos, apresentando conteúdos de $\mathrm{SiO}_{2}$ (39,28\% a 45,83\%), em geral, menores e de $\operatorname{MgO}(25,50 \%$ a $37,77 \%)$ e \#Mg $(0,85$ a 0,89$)$ mais elevados. Apresentam ainda, em comparação com as demais rochas metaultramáficas, os 
mais baixos conteúdos de $\mathrm{CaO}(0,01 \%$ a $4,10 \%)$ e de $\mathrm{Al}_{2} \mathrm{O}_{3}(0,56 \%$ a $1,99 \%)$, exceto em uma amostra que apresentou valores de $\mathrm{Al}_{2} \mathrm{O}_{3}$ de $8,31 \%$.

Tabela 3. Composições químicas médias de rochas metaultramáficas e metamáficas do greenstone belt Sapucaia, região de Carajás.

\begin{tabular}{|c|c|c|c|c|c|c|}
\hline & \multicolumn{4}{|c|}{ METAULTRAMÁFICAS } & \multirow{2}{*}{$\begin{array}{c}\text { METABÁSICAS } \\
\text { (Mg)-Hb } \\
\text { anfibolito }\end{array}$} & \multirow{2}{*}{$\frac{\text { GABROS }}{\text { Gabros }}$} \\
\hline & Cloritito & $\begin{array}{c}\text { (Antofilita)- } \\
\text { Mg-cum xisto }\end{array}$ & Chl-Tr xisto & Chl-act xisto & & \\
\hline $\mathrm{SiO}_{2}(\%)$ & 27,66 & 42,18 & 47,72 & 45,18 & 50,14 & 51,3 \\
\hline $\mathrm{TiO}_{2}$ & 2,76 & 0,09 & 0,43 & 0,4 & 0,53 & 0,85 \\
\hline $\mathrm{Al}_{2} \mathrm{O}_{3}$ & 17,14 & 3,59 & 6 & 6,7 & 12,55 & 14,24 \\
\hline $\mathrm{Fe}_{2} \mathrm{O}_{3}$ & 12,93 & 8,8 & 11,73 & 12,75 & 10,28 & 12,41 \\
\hline $\mathrm{MnO}$ & 0,08 & 0,12 & 0,19 & 0,18 & 0,19 & 0,19 \\
\hline $\mathrm{MgO}$ & 25,82 & 31,8 & 20,88 & 20,27 & 11,03 & 7,28 \\
\hline $\mathrm{CaO}$ & 1,12 & 1,59 & 8,14 & 7,49 & 12,09 & 10,94 \\
\hline $\mathrm{Na}_{2} \mathrm{O}$ & 0,01 & 0,02 & 0,19 & 0,15 & 1,52 & 1,84 \\
\hline $\mathrm{K}_{2} \mathrm{O}$ & 0,01 & 0,01 & 0,01 & 0,01 & 0,21 & 0,39 \\
\hline $\mathrm{P}_{2} \mathrm{O}_{5}$ & 0,86 & 0,01 & 0,02 & 0,03 & 0,05 & 0,09 \\
\hline LOI & 10,9 & 10,53 & 3,85 & 6 & 1 & 0,15 \\
\hline TOTAL & 99,29 & 98,74 & 99,16 & 99,16 & 99,59 & 99,68 \\
\hline$M g \#$ & 0,8 & 0,88 & 0,78 & 0,76 & 0,67 & 0,54 \\
\hline $\mathrm{CaO} / \mathrm{Al}_{2} \mathrm{O}_{3}$ & 0,07 & 0,28 & 1,39 & 1,24 & 1,25 & 0,77 \\
\hline $\mathrm{Al}_{2} \mathrm{O}_{3} / \mathrm{TiO}_{2}$ & 6,2 & 32,83 & 13,9 & 18,48 & 26,8 & 16,75 \\
\hline $\mathrm{CaO} / \mathrm{TiO}_{2}$ & 0,4 & 10,47 & 18,84 & 23,7 & 29,1 & 12,87 \\
\hline $\mathrm{Cr}_{2} \mathrm{O}_{3}$ & 0,05 & 0,47 & 0,25 & 0,26 & 0,13 & 0,02 \\
\hline $\mathrm{V}(\mathrm{ppm})$ & 390 & 69,33 & 144,8 & 144 & 241 & 253 \\
\hline $\mathrm{Ba}$ & 101 & 13,33 & 15,8 & 7,67 & 57 & 105,5 \\
\hline Co & 123,4 & 85,97 & 82,24 & 78,2 & 57,8 & 62,45 \\
\hline $\mathrm{Nb}$ & 9,2 & 0,8 & 8,96 & 2,67 & 4,5 & 4,85 \\
\hline $\mathrm{Ni}$ & 581 & 1045 & 971,2 & 1045 & 161 & 94 \\
\hline $\mathrm{Rb}$ & 0,1 & 0,63 & 0,94 & 0,77 & 4,2 & 13,06 \\
\hline $\mathrm{Sr}$ & 25,9 & 2,87 & 19,5 & 23,53 & 187,1 & 109,95 \\
\hline $\mathrm{Y}$ & 50 & 3,27 & 39,54 & 45,37 & 12,6 & 19,5 \\
\hline $\mathrm{Zr}$ & 246 & 7,37 & 24,7 & 24,67 & 34,2 & 65,75 \\
\hline $\mathrm{Y} / \mathrm{Zr}$ & 0,2 & 0,44 & 1,6 & 3,08 & 0,37 & 0,3 \\
\hline $\mathrm{La}(\mathrm{ppm})$ & 41,8 & 0,83 & 51,26 & 21,6 & 39,9 & 6,85 \\
\hline $\mathrm{Ce}$ & 85,1 & 0,7 & 9,22 & 3,73 & 7,6 & 14,35 \\
\hline $\operatorname{Pr}$ & 10,53 & 0,13 & 9,77 & 4,87 & 1,17 & 1,88 \\
\hline $\mathrm{Nd}$ & 42,8 & 0,63 & 37,28 & 20,8 & 4,9 & 8,7 \\
\hline $\mathrm{Sm}$ & 9,49 & 0,21 & 6,52 & 4,64 & 1,49 & 2,31 \\
\hline $\mathrm{Eu}$ & 0,93 & 0,05 & 1,91 & 1,65 & 0,56 & 0,77 \\
\hline Gd & 10,05 & 0,38 & 7,29 & 6,7 & 2,06 & 3,06 \\
\hline $\mathrm{Tb}$ & 1,53 & 0,07 & 1,03 & 1,06 & 0,35 & 0,51 \\
\hline Dy & 9,15 & 0,54 & 5,81 & 6,78 & 2,32 & 3,31 \\
\hline Ho & 1,76 & 0,12 & 1,15 & 1,38 & 0,45 & 0,71 \\
\hline $\mathrm{Er}$ & 4,77 & 0,35 & 3,04 & 3,71 & 1,47 & 2,08 \\
\hline $\mathrm{Tm}$ & 0,62 & 0,06 & 0,38 & 0,48 & 0,2 & 0,29 \\
\hline $\mathrm{Yb}$ & 3,75 & 0,38 & 2,14 & 2,87 & 1,42 & 2,12 \\
\hline $\mathrm{Hf}$ & 5,9 & 0,2 & 0,76 & 0,77 & 1,1 & 1,95 \\
\hline $\mathrm{Ta}$ & 0,9 & 0,1 & 0,16 & 0,1 & 0,3 & 0,5 \\
\hline $\mathrm{Pb}$ & 0,6 & 0,6 & 0,36 & 0,13 & 0,9 & 2 \\
\hline Th & 9,8 & 0,2 & 0,22 & 0,3 & 0,6 & 0,3 \\
\hline $\mathrm{U}$ & 1,7 & 0,17 & 0,1 & 0,1 & 0,3 & 1,5 \\
\hline $\mathrm{Be}$ & 1 & 1 & 1,4 & 1 & 1 & 0,31 \\
\hline $\mathrm{Lu}$ & 0,53 & 0,06 & 0,29 & 0,39 & 0,2 & 94,5 \\
\hline $\mathrm{Sc}$ & 65 & 14 & 21,8 & 23 & 46 & 39,5 \\
\hline$\Sigma$ REE & 307,71 & 20,78 & 161,89 & 106,06 & 114,29 & 94,2 \\
\hline$(\mathrm{La}-\mathrm{Sm})_{\mathrm{N}}$ & 2,7 & 4,03 & 3,95 & 2,9 & 1,5 & 1,8 \\
\hline$(\mathrm{Gd}-\mathrm{Yb})_{\mathrm{N}}$ & 2,1 & 0,72 & 2,5 & 1,9 & 1,2 & 1,7 \\
\hline$(\mathrm{La}-\mathrm{Yb})_{\mathrm{N}}$ & 7,5 & 2,3 & 13,25 & 5,0 & 2,2 & 2,26 \\
\hline
\end{tabular}


No diagrama TAS de Le Bas et al. 1986, esses litotipos plotam juntamente com a maioria das demais amostras de rochas metaultramáficas no campo dos basaltos, uma vez que todos esses litotipos apresentam conteúdos de $\mathrm{Na}_{2} \mathrm{O}+\mathrm{K}_{2} \mathrm{O}$ baixos, entre 0,05 e 0,34\% (Fig. 39). Como os conteúdos de $\mathrm{SiO}_{2}$ são mais elevados nos clorita-tremolita xistos $(43,06 \%$ a $49,30 \%)$ e clorita-actinolita xistos $(45,93 \%$ a $49,75 \%)$, três de suas amostras plotam na interface com o campo dos basaltos andesíticos. Esse conjunto de clorita-tremolita xistos e clorita-actinolita xistos apresenta intervalos semelhantes de valores de $\mathrm{MgO}(18,98 \%$ a $22 \%)$, $\# \mathrm{Mg}\left(0,73\right.$ a 0,80), $\mathrm{CaO}(6,50 \%$ a $9,51 \%)$ e $\mathrm{Al}_{2} \mathrm{O}_{3}(4,58$ a $9,71 \%)$.

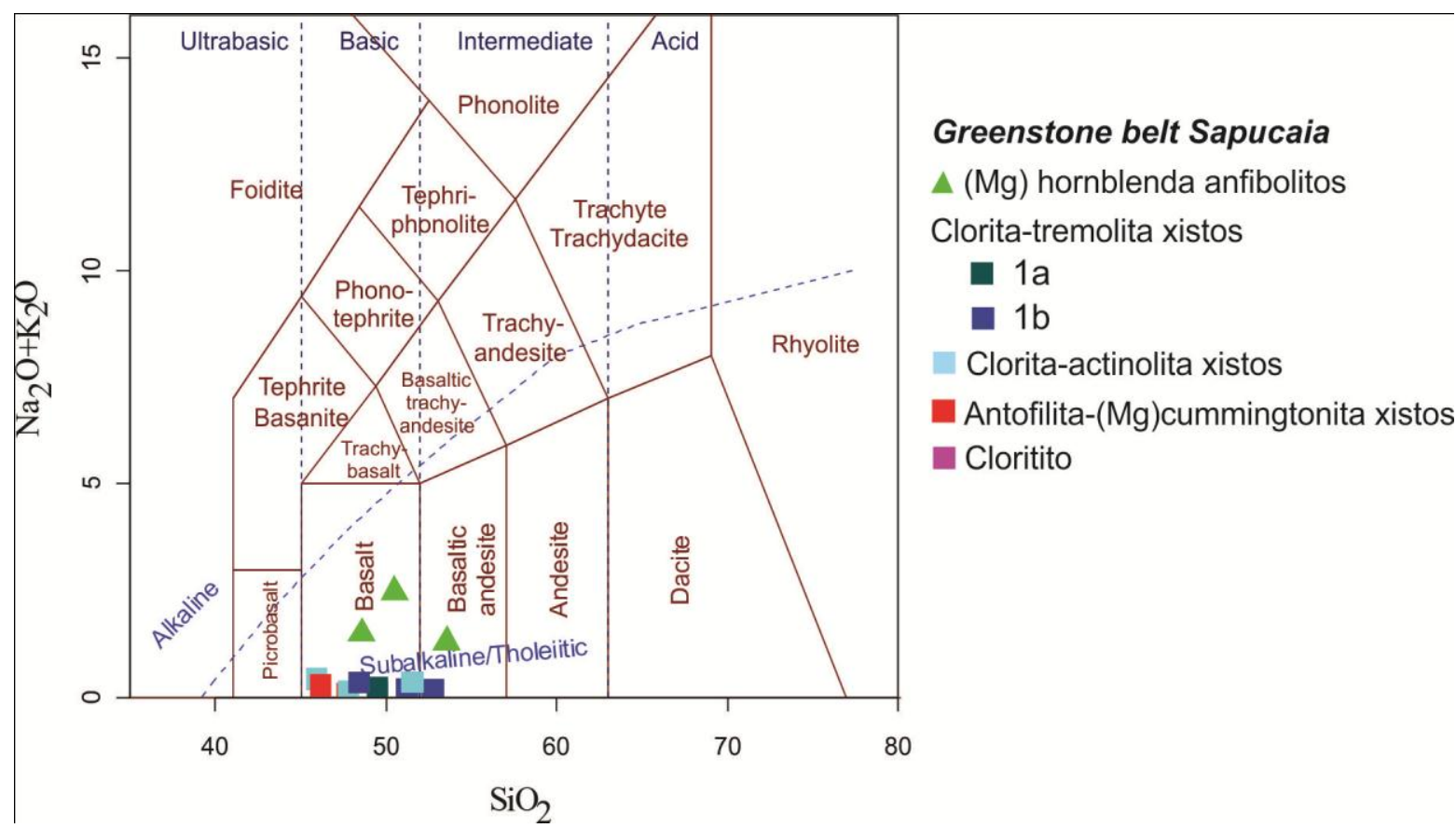

Figura 39. Diagrama TAS (Le Bas et al. 1986) mostrando variação nos conteúdos de sílica e álcalis, das rochas metaultramáficas e nos metabasitos, classificadas como basaltos e andesitos basálticos. Os dados plotados foram recalculados considerando-se base anidra.

Segundo o diagrama para rochas ultrabásicas a intermediárias de Le Maitre (1989), todas as rochas metaultramáficas são classificadas como komatiítos (Fig. 40), devido aos seus valores de $\mathrm{MgO}>18 \%$ e os de $\mathrm{TiO}_{2}<1 \%$ (entre 0,02 e 0,53\%). Esse diagrama, além de mostrar significativo espalhamento dos valores de $\mathrm{SiO}_{2}$ para o conjunto de amostras, também evidencia as significativas diferenças químicas da amostra de cloritito. Esse litotipo distinguese, em relação aos elementos maiores, de todos os demais devido a seus valores mais baixos de $\mathrm{SiO}_{2}(27,66 \%)$ e mais elevados de $\mathrm{TiO}_{2}(2,76 \%), \mathrm{Al}_{2} \mathrm{O}_{3}(17,14 \%), \mathrm{Fe}_{2} \mathrm{O}_{3 \mathrm{~T}}(12,93 \%)$ e $\mathrm{P}_{2} \mathrm{O}_{5}$ $(0,86 \%)$.

No diagrama de Jensen (1976; Fig. 41), todas as amostras plotaram no campo dos komatiítos peridotíticos, exceto o cloritito e uma amostra de clorita-actinolita xisto (MCS 10) que plotaram no campo dos komatiítos basálticos. Essa diferença reflete o maior conteúdo de 
alumínio dessas amostras, que é notável no cloritito (17,14\%), mas também é mais elevado na amostra MCS $10\left(\mathrm{Al}_{2} \mathrm{O}_{3}=9,71 \%\right)$, em relação às demais $\left(4,58-8,21 \%\right.$ de $\left.\mathrm{Al}_{2} \mathrm{O}_{3}\right)$.

Adicionalmente, o diagrama de Jensen (1976) ilustra claramente diferenças composicionais entre os antofilita-Mg-cummingtonita e o conjunto de tremolita-clorita xistos e actinolita-clorita xistos, que apresentam conteúdos mais elevados de $\mathrm{Fe}_{\mathrm{T}}+\mathrm{Ti}$.

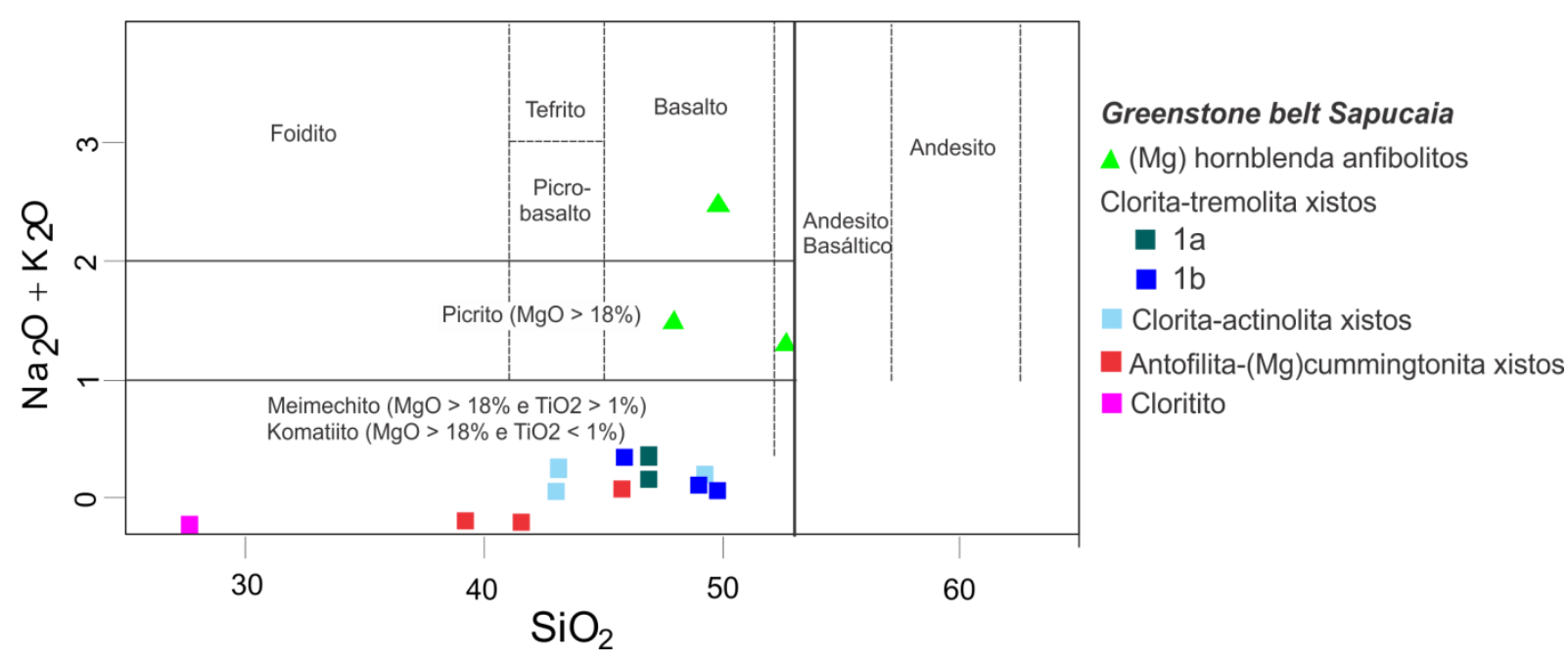

Figura 40. Diagrama de Le Maitre (1989) para classificação de rochas vulcânicas ultrabásicas a intermediárias, mostrando a composição das rochas metaultramáficas e metamáficas do Greenstone Belt Sapucaia em relação a seus conteúdos de $\mathrm{SiO}_{2}$ e $\mathrm{Na}_{2} \mathrm{O}+\mathrm{K}_{2} \mathrm{O}$. As rochas metaultramáficas, devido a seu quimismo, poderiam ser classificadas como komatiítos, embora para essa classificação evidências texturais que comprovem a origem vulcânica sejam necessários.

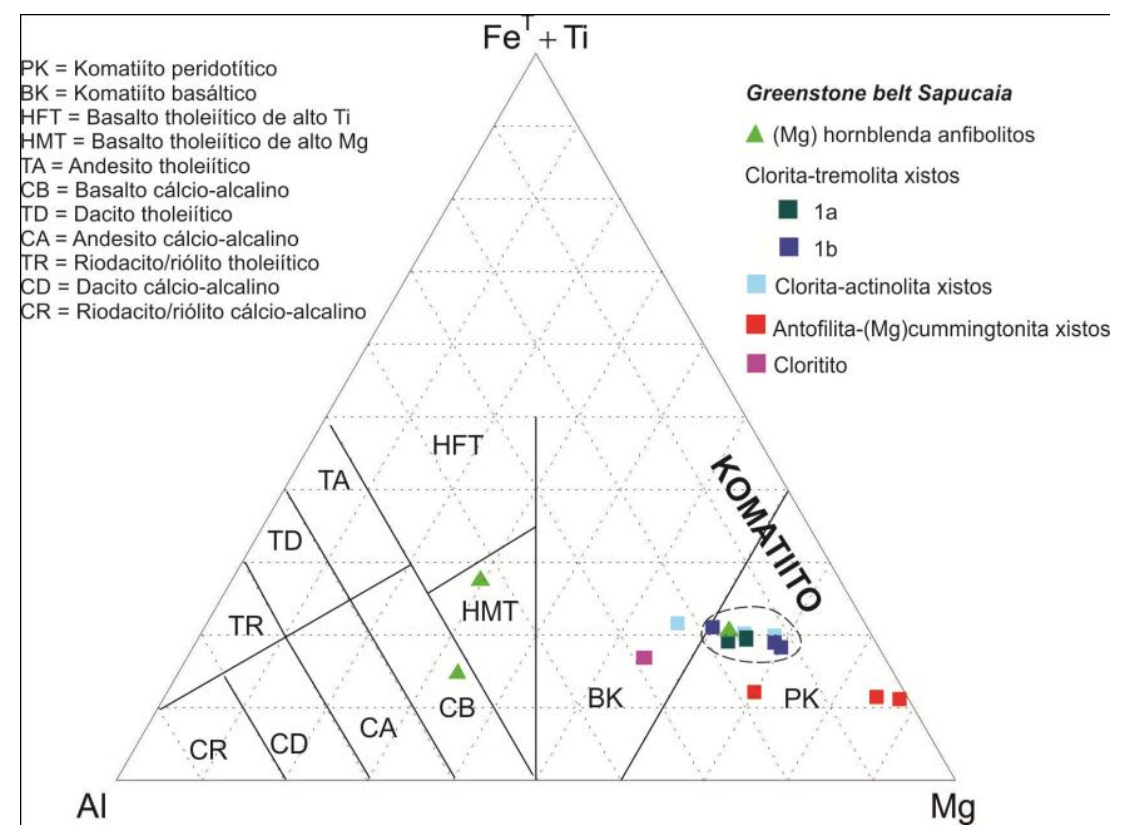

Figura 41. Diagrama catiônico de Jensen (1976) para classificação de rochas máficas e ultramáficas. Nota-se a concentração das rochas metaultramáficas no campo dos komatiítos peridotíticos e dos komatiítos basálticos, onde plotam duas amostras. Entre as rochas metamáficas, nota-se dispersão, com composições variando entre komatiítos basálticos, basaltos tholeiíticos de alto $\mathrm{Mg}$ e basalto cálcio-alcalino. 
A distinção dos antofilita-Mg cummingtonita xistos em relação aos demais litotipos metaultramáficos também é mostrada no diagrama de Viljoen et al. (1982), no qual apenas os clorita-tremolita xistos e clorita-actinolita xistos apresentam composição coincidente com a dos komatítos basálticos, próximo à interface com o campo dos komatiítos peridotíticos (Fig. 42). Por sua vez, os antofilita-Mg-cummingtonita não plotam em nenhum dos campos apresentados no diagrama, mostrando em duas amostras composições ainda mais magnesianas que as dos komatiítos peridotíticos.

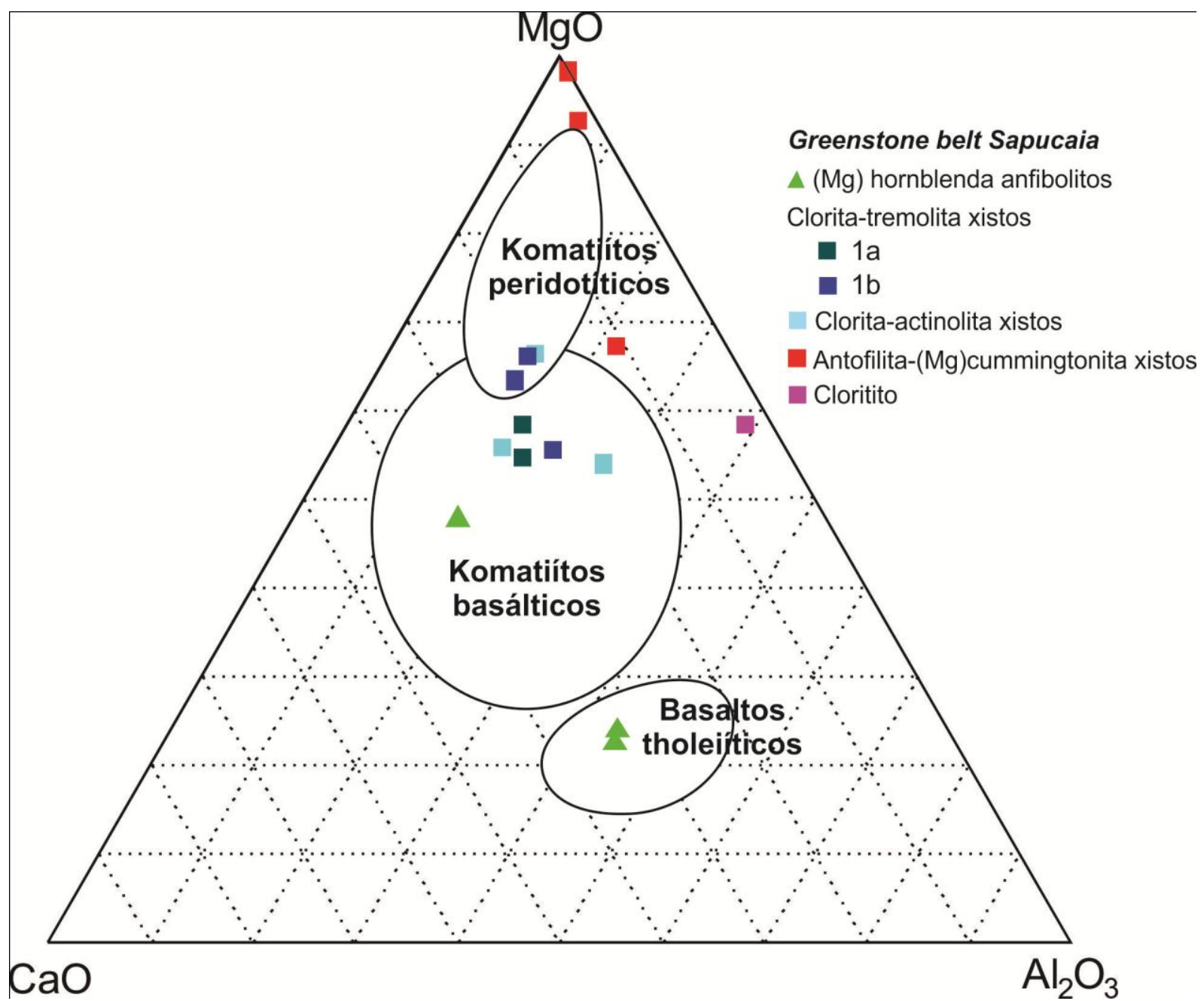

Figura 42. Diagrama ternário $\mathrm{MgO}-\mathrm{CaO}-\mathrm{Al}_{2} \mathrm{O}_{3}$ para classificação de komatiítos do tipo Barbenton (Al-depleted komatiites) e rochas relacionadas (Viljoen et al., 1982), mostrando semelhança dos clorita-tremolita xistos e clorita-actinolita xistos com a composição dos komatí́tos basálticos, próximo à interface com os komatiítos peridotíticos. Amostras de antofilita-Mg cummingtonita xistos e cloritito não plotam em nenhum dos campos composicionais.

Embora, o conjunto de clorita-tremolita xistos e clorita-actinolita xistos apresentem semelhanças químicas com rochas komatiíticas, a definição de komatiíto recomendada por Arndt et al. (2008) estabelece que "komatiíto é uma rocha vulcânica ultramáfica com textura 
spinifex ou relacionada a derrames de lavas contendo essa textura". Assim, a ausência de texturas preservadas nos litotipos estudados ou a associação clara desse litotipos com outros do Greenstone Belt Sapucaia nos quais a textura spinifex já foi descrita, dificulta sua classificação definitiva.

Adicionalmente, de acordo com Arndt et al. (2008), líquidos komatiíticos apresentam um limite máximo de $30 \%$ de $\mathrm{MgO}$ e rochas com conteúdos superiores de $\mathrm{MgO}$, semelhantes a duas das amostras de antofilita-Mg-cummingtonita xistos, podem representar rochas cumuláticas (olivine cumulates), que comumente associam-se aos derrames.

Embora seja necessária cautela com a classificação das rochas aqui estudadas, sua comparação com outros atributos das rochas komatiíticas pode ser útil. Segundo Arndt et al. (2008), os komatítos possuem algumas diferenças geoquímicas, podendo ser distinguidos com base na razão $\mathrm{Al}_{2} \mathrm{O}_{3} / \mathrm{TiO}_{2}$ e elementos terras raras (ETR). O komatiítos podem ser divididos nos seguintes grupos: (1) empobrecido em Al, do tipo Barberton, com baixa razão $\mathrm{Al}_{2} \mathrm{O}_{3} / \mathrm{TiO}_{2}$ e elevada razão $(\mathrm{Gd} / \mathrm{Yb})_{\mathrm{N}}$; (2) do tipo Munro, que apresentam razões $\mathrm{Al}_{2} \mathrm{O}_{3} / \mathrm{TiO}_{2}$ e $(\mathrm{Gd} / \mathrm{Yb})_{\mathrm{N}}$ próximas a do condrito; e (3) enriquecidos em Al, semelhantes aos da Ilha de Gorgona, Colômbia, com valores de $\mathrm{Al}_{2} \mathrm{O}_{3} / \mathrm{TiO}_{2}$ mais elevados e (4) ricos em Ti, como aqueles do escudo Báltico, Canadá.

\subsubsection{Elementos maiores e menores}

As rochas de afinidade komatiítica do Greenstone Belt Sapucaia (clorita-tremolita xistos e clorita-actinolita xistos) apresentam conteúdos intermediários de $\mathrm{Al}_{2} \mathrm{O}_{3}$ entre aqueles dos komatiítos dos tipos Barbeton e Munro e conteúdos de $\mathrm{TiO}_{2}$ semelhantes aos dois tipos. Contudo, suas razões $\mathrm{Al}_{2} \mathrm{O}_{3} / \mathrm{TiO}_{2}$ são comparáveis apenas às dos komatiítos dos tipos Barbeton, não empobrecidos em alumínio. As razões $\mathrm{CaO} / \mathrm{Al}_{2} \mathrm{O}_{3}$ de $1,03 \%$ a $1,68 \%$ desse conjunto de rochas também são análogas às dos komatiítos do tipo Barbeton, exceto em uma amostra (MCS10), que mostra razão de 0,68. Adicionalmente, as razões $(\mathrm{Gd} / \mathrm{Yb})_{\mathrm{N}}$ são superiores a 1, o que também é verificado apenas nos komatiítos do tipo Barbeton. Entretanto, os valores de $(\mathrm{Gd} / \mathrm{Yb})_{\mathrm{N}}$ de 1,31 a 3,46 são ainda mais elevados que os reportados para komatiítos desse tipo, além de evidenciarem maior dispersão (Fig. 43).

A figura 43 também mostra que as amostras de antofilita-Mg-cummingtonita xistos que assemelham-se, em termos de seus conteúdos de $\mathrm{MgO}$, com as rochas cumuláticas associadas a komatítos, diferem dessas devido a seus valores mais baixos de $\mathrm{Al}_{2} \mathrm{O}_{3}$ e $\mathrm{TiO}_{2}$. $\mathrm{O}$ cloritito, por sua vez, diferencia-se de todas as demais, devido seu conteúdo mais elevado de $\mathrm{Al}_{2} \mathrm{O}_{3}$ e $\mathrm{TiO}_{2}$, embora seu valor de $(\mathrm{Gd} / \mathrm{Yb})_{\mathrm{N}}$ seja próximo aos de outros litotipos do Greenstone Belt Sapucaia. 
As rochas metabásicas, apresentam conteúdos de $\mathrm{SiO}_{2}$ (49,81\% a 52,67\%), $\mathrm{MgO}(7,69$ a $16,14 \%)$ e $\mathrm{Na}_{2} \mathrm{O}+\mathrm{K}_{2} \mathrm{O}(1,28$ a 2,45\%) semelhantes à de basaltos e andesitos basálticos (Fig. 39), segundo a classificação Le Bas et al. (1986), e de basaltos (Fig. 40), de acordo com Le Maitre (1989). No diagrama catiônico de Jensen (1976; Fig. 41), os litotipos metabásicos mostram dispersão $\left(\mathrm{Al}_{2} \mathrm{O}_{3}=5,41-18,23 \%\right)$, coincidindo com os campos de komatiítos peridotíticos, basaltos tholeiíticos de alto magnésio e basaltos cálcio-alcalinos. Similar espalhamento é observado no diagrama de Viljoen et al. (1982), no qual duas amostras plotam no campo dos basaltos tholeiíticos, mas uma coincide com o campo dos komatítos basálticos.
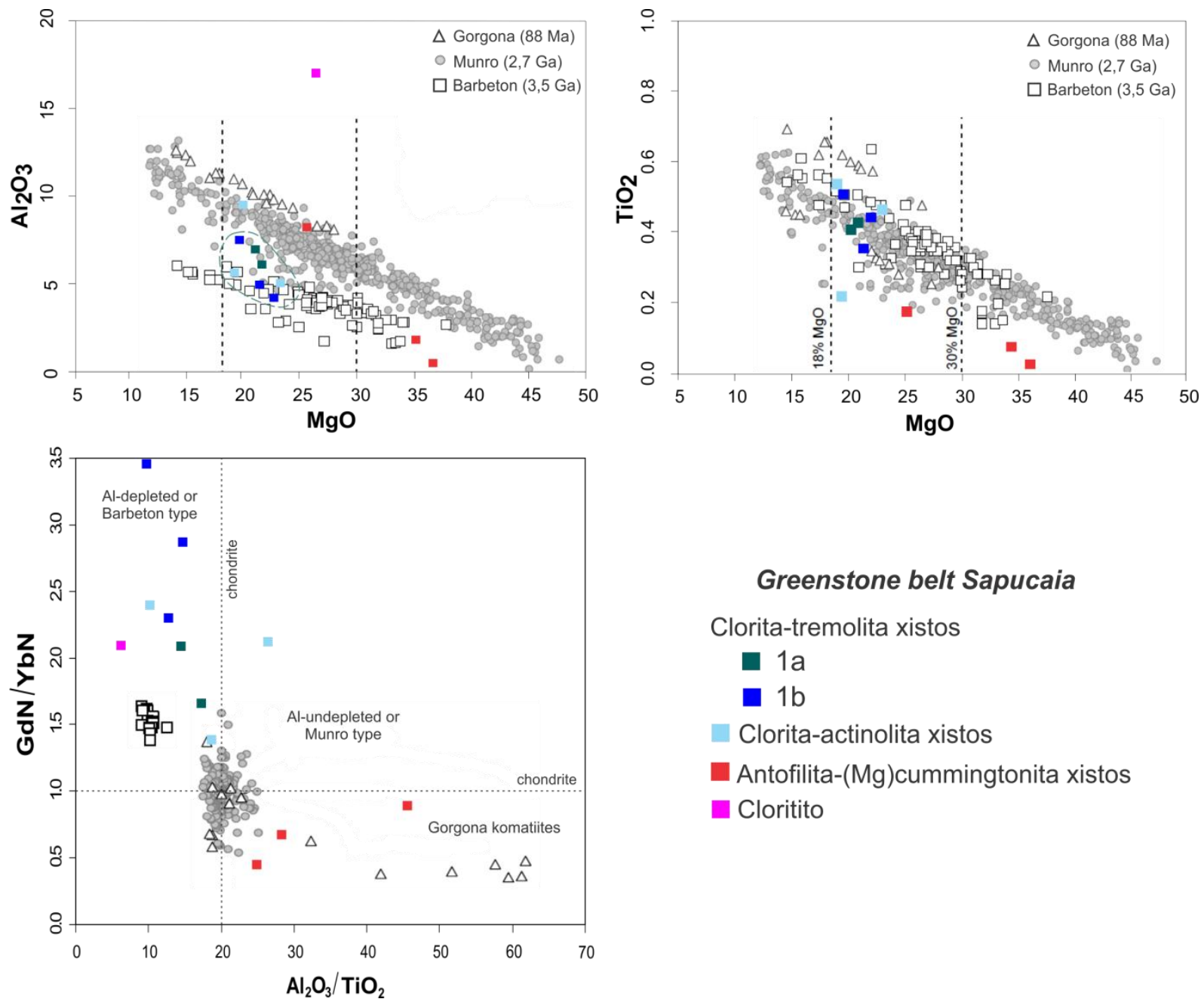

\section{Greenstone belt Sapucaia}

Clorita-tremolita xistos

$\mathbf{1 a}$
$\mathbf{1} 1 \mathrm{~b}$
Clorita-actinolita xistos
Antofilita-(Mg)cummingtonita xistos
Cloritito

Figura 43. Diagramas que ilustram a composição dos principais tipos de komatiítos (tipos Barbenton, Munro e Gorgona), de acordo com Arndt et al. (2008), e a comparação desses com as rochas do Greenstone Belt Sapucaia. O limite de $18 \% \mathrm{MgO}$ separa basaltos komatítos de komatiítos e o limite em $30 \% \mathrm{MgO}$ indica o teor máximo provável de líquidos komatiíticos. Rochas com mais de 30\% de $\mathrm{MgO}$ representam cumulatos de olivina. Notar que no diagrama $\mathrm{TiO}_{2}$ vs $\mathrm{MgO}$, o cloritito não foi plotado, devido a seu conteúdo muito mais elevado de $\mathrm{TiO}_{2}(2,76 \%)$. No diagrama $\mathrm{Al}_{2} \mathrm{O}_{3} / \mathrm{TiO}_{2}$ vs $(\mathrm{Gd} / \mathrm{Yb})_{\mathrm{N}}$, as altas razões $(\mathrm{Gd} / \mathrm{Yb})_{\mathrm{N}}$ e baixas de $\mathrm{Al}_{2} \mathrm{O}_{3} / \mathrm{TiO}_{2}$, indicam que granada foi mantida no resíduo de fusão e que os magmas foram formados em grandes profundidades no manto. 
No diagrama AFM (Irvine \& Baragar, 1971), as metaultramáficas definem a tendência komatiítica clássica, enquanto os metabasitos mostram tendência tholeiítica (Fig. 44). Os mesmos litotipos são classificados pelo diagrama de Hastie et al. (2007), considerando os conteúdos de Co e Th, como basaltos pertencentes à série tholeiítica, exceto duas amostras de metabasito que apresentaram conteúdos mais elevados de Th que os típicos de magmas tholeiíticos (Fig. 45). As amostras de cloritito e antofilita-Mg-Cummingtonita xistos, contudo, não estão representadas nesse diagrama, devido a seus valores elevados de Co (60 a 123 ppm).
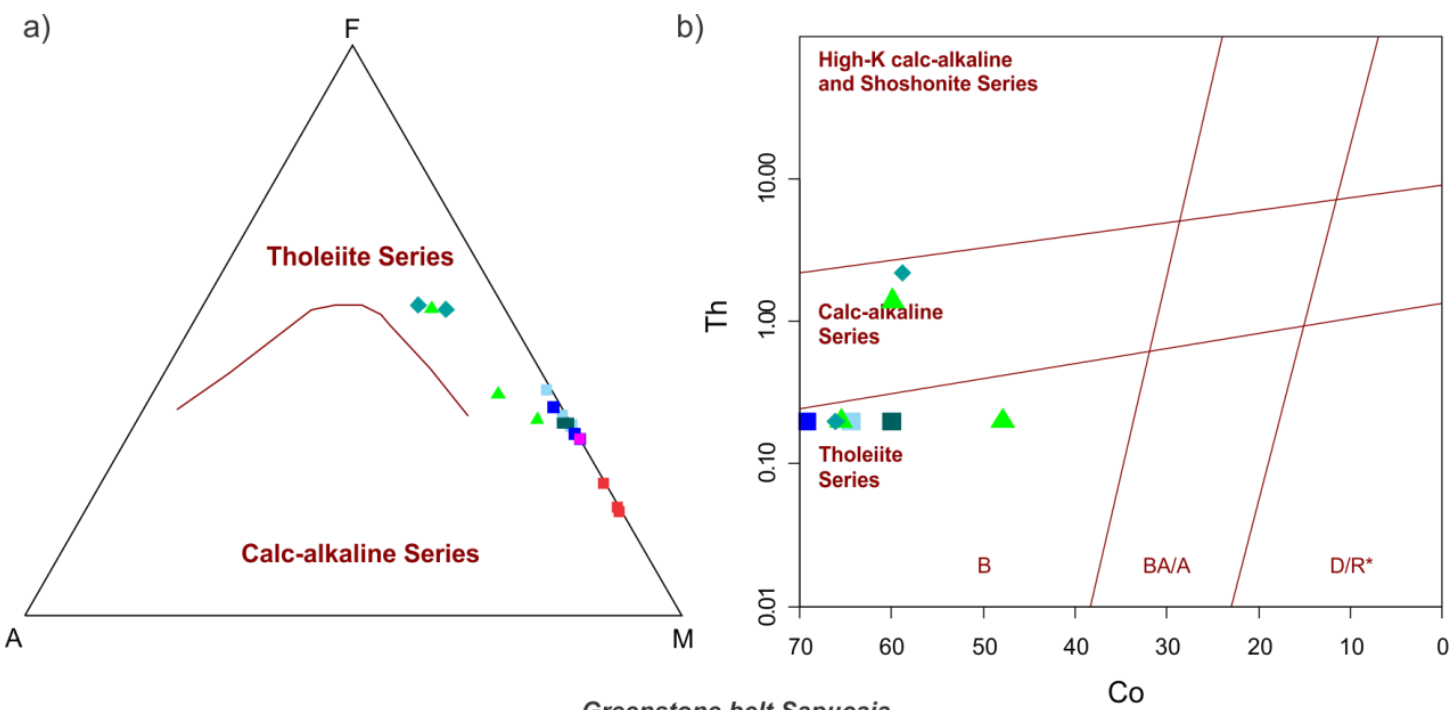

Greenstone belt Sapucaia

$\begin{array}{ll}\Delta(\mathrm{Mg}) \text { hornblenda anfibolitos } & \text { Clorita-actinolita xistos } \\ \text { Clorita-tremolita xistos } & \text { Antofilita-(Mg)cummingtonita xistos } \\ \square \text { 1a } & \text { Cloritito } \\ \square \text { 1b } & \text { Gabros }\end{array}$

Figura 44. a) Diagrama AFM de Irvine \& Baragar (1971), mostrando para as rochas metaultramáficas tendência komatiítica e tendência tholeiítica para as rochas metabásicas; b) No diagrama de Hastie et al. (2007), os litotipos metaultramáficos possuem tendência tholeiítica, exceto o cloritito e o antofilita-( $\mathrm{Mg})$ cummingtonita xistos, enquanto para os metabasitos, duas amostras evidenciam tendência cálcio-alcalina.

Em todos os diagramas utilizados, as rochas metaultramáficas e metabasitos revelam alguma dispersão, que pode refletir processos de alteração pós-magmáticos. Com o uso do diagrama de Hughes (1973) é possível realizar uma avaliação preliminar das modificações na composição das rochas, observando se as amostras se concentram ou não dentro do espectro ígneo. Nesse diagrama (Fig. 45), todas as rochas metaultramáficas plotaram fora do campo referente ao espectro ígneo, indicando que essas rochas sofreram, em algum grau, metassomatismo que modificou sua composição. Esses processos foram aparentemente menos intensos no conjunto de tremolita-clorita xistos e actinolita xistos, embora ao menos duas 
amostras do conjunto revelem expressiva modificação. Os processos metassomáticos foram extremos no cloritito, sendo que duas amostras de antofilita-Mg-cummingtonita xistos plotam exatamente na mesma posição do cloritito no gráfico. Em relação aos metabasitos, apenas uma amostra (MCLS17), classificada como basalto tholeiítico, ainda preservou características composicionais ígneas (Fig. 45).

Dessa forma, o uso de elementos maiores, especialmente os relativamente mais móveis, para a caracterização de processos petrogenéticos e evolução magmática do Greenstone Sapucaia, deve ser evitado, ou considerado com a máxima cautela.

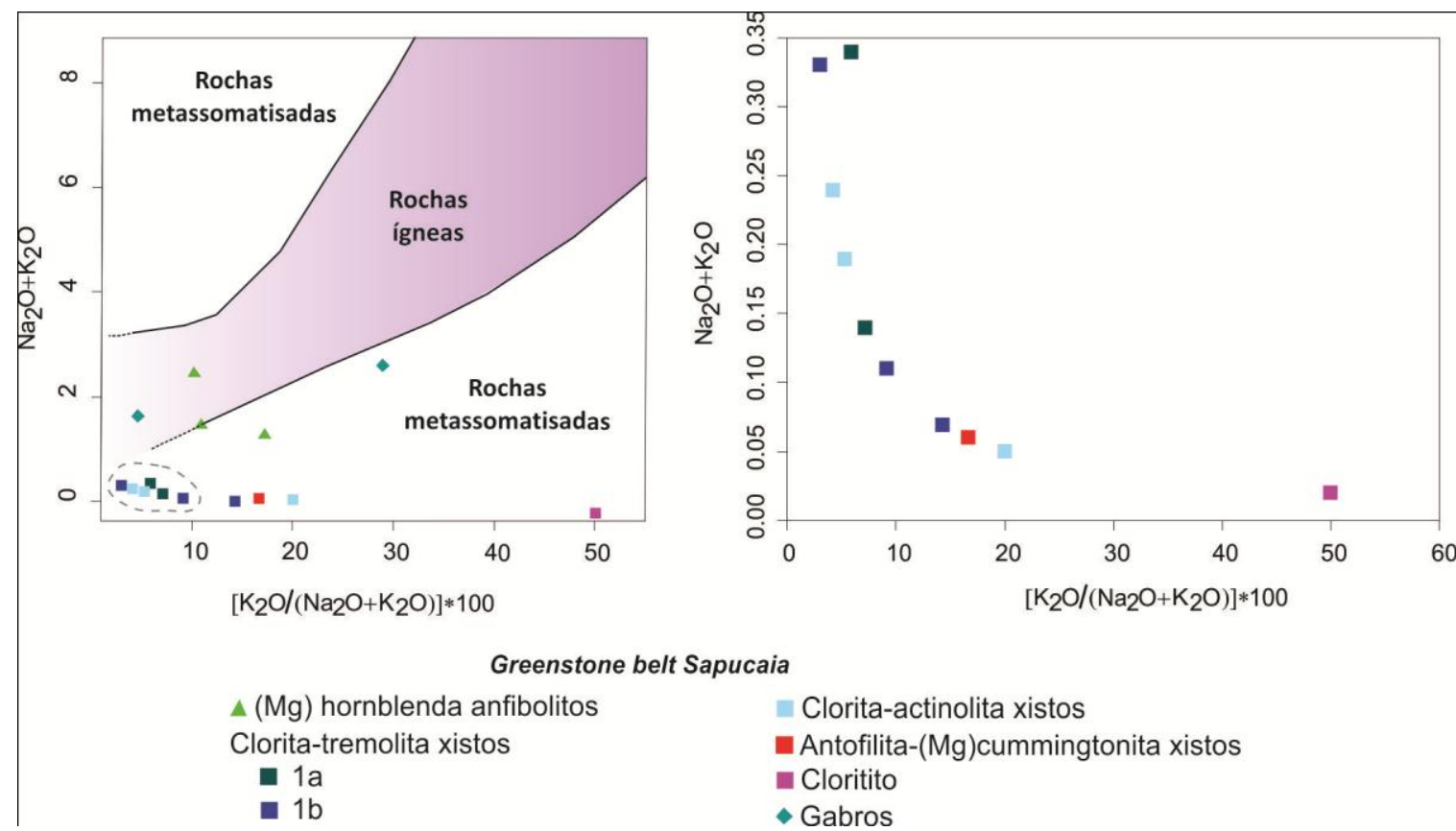

Figura 45. Diagrama de Hughes (1973) mostrando o campo do espectro ígneo e, fora desse campo, rochas alteradas por processos metassomáticos. Ao lado direito, detalhe das rochas metaultramáficas.

$\mathrm{Na}$ figura 46 é possível observar para o conjunto de litotipos metaultramáficos, tendência de correlação negativa entre \# $\mathrm{Mg}$ e $\mathrm{CaO}$. A amostra de cloritito e as de cloritaactinolita xistos, contudo, não alinham-se bem às demais. Em relação aos metabasitos, apenas duas amostras de hornblenda anfibolitos apresentam tendência similar à das rochas metaultramáficas. Correlação negativa entre \#Mg e $\mathrm{Na}_{2} \mathrm{O}$, porém com trends distintos, também é sugerida para os clorita-tremolita e clorita-actinolita xistos e para os metabasitos. Em relação ao $\mathrm{FeO}_{\mathrm{t}}$, apenas para o primeiro conjunto uma tendência negativa de correlação é sugerida. $\mathrm{O}$ conteúdos mais elevado de $\mathrm{P}_{2} \mathrm{O}_{5}$ do cloritito $(0,86 \%)$ mascara no diagrama da figura 46 a leve tendência de correlação negativa com \#Mg dos demais litotipos. 
Considerando-se o \#Mg como um índice de diferenciação, as tendências observadas na figura 46 são compatíveis com a evolução magmática a partir do fracionamento de olivina e ortopiroxênio, que causa progressiva diminuição dos conteúdos de $\mathrm{MgO}$ e relativo aumento dos conteúdos de $\mathrm{Al}_{2} \mathrm{O}_{3}, \mathrm{FeOt}, \mathrm{CaO}$ e $\mathrm{Na}_{2} \mathrm{O}$. Contudo, uma certa dispersão das amostras de clorita-actinolita xistos, em relação às amostras de clorita-tremolita xistos, mais alinhadas, aponta para significativas mudanças pós-magmáticas nessas amostras.

Os diagramas de Harker apresentados na figura 47, apenas sugerem alguma tendência de correlação negativa entre os conteúdos de $\mathrm{SiO}_{2}$ vs. $\mathrm{Al}_{2} \mathrm{O}_{3}, \mathrm{CaO}$ e $\mathrm{FeO}_{\mathrm{t}}$ para os cloritatremolita xistos. As amostras de clorita-actinolita xistos novamente revelam maior dispersão, que pode refletir processos metassomáticos mais intensos em relação aos registrados nos clorita-tremolita xistos. No gráfico $\mathrm{SiO}_{2}$ vs. $\# \mathrm{Mg}$, correlação positiva é sugerida apenas para os clorita-tremolita xistos. Essa tendência, contudo, é contrária à esperada a partir da evolução magmática de magmas ultramáficos.

A figura 47 também apresenta comparação entre rochas metaultramáficas e máficas do Greenstone Belt Sapucaia com aquelas reportadas previamente para os greenstone belts do Domínio Rio Maria por Souza et al. (1997).

Os metabasitos mostram maior espalhamento nos gráficos em relação ao campo dos basaltos tholeí́ticos definido por esses autores, possivelmente devido ao metassomatismo. Os clorita-tremolita xistos, que aparentemente representam os litotipos metaultramáficos menos metassomatisados, apresentam algumas semelhanças em termos de seus conteúdos de $\mathrm{CaO}$, $\mathrm{FeO}_{\mathrm{t}}$ e \#Mg com aqueles dos greenstone belts do Domínio Rio Maria, contudo, seus conteúdos de $\mathrm{Al}_{2} \mathrm{O}_{3}$ são menores (Fig. 47). 

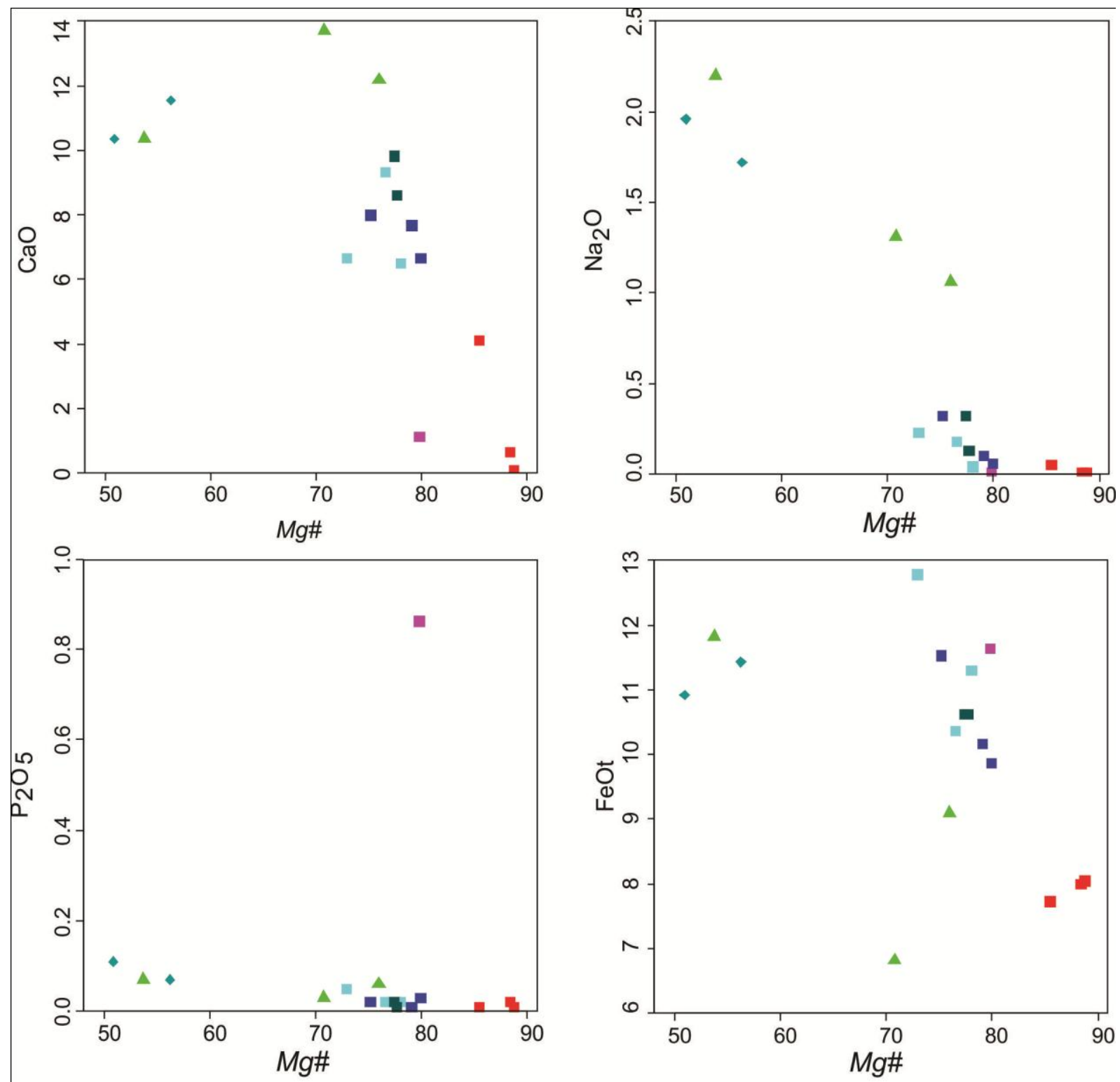

Greenstone belt Sapucaia

Clorita-tremolita xistos

- 1a

$1 \mathrm{~b}$

Clorita-actinolita xistos
Antofilita-(Mg)cummingtonita xistos

Cloritito

$\Delta(\mathrm{Mg})$ hornblenda anfibolitos

- Gabros

Figura 46. Diagramas binários mostrando variações dos conteúdos de \# $\mathrm{Mg}$ vs. $\mathrm{CaO}, \mathrm{Na}_{2} \mathrm{O}, \mathrm{P}_{2} \mathrm{O}_{5}$ e FeOt nos metabasitos e rochas metaultramáficas do Greenstone Belt Sapucaia.

As variações de elementos traços em relação ao \#Mg revelam grande espalhamento das amostras de metabasitos e litotipos metaultramáficos, sobretudo quando são considerados seus conteúdos de $\mathrm{Rb}$, Ba e $\mathrm{Sr}$ (Fig. 48), o que pode ser atribuído a processos pósmagmáticos. Correlação positiva entre \#Mg e $\mathrm{Cr}_{2} \mathrm{O}_{3}$ é observada para o conjunto de metabasitos e litotipos com afinidade komatítica (clorita-tremolita xistos e clorita-actinolita xistos), como esperado durante evolução magmática controlada pelo fracionamento de olivina e cromita. Em relação ao Ni, também compatível, essa relação apenas é sugerida para 
os metabasitos. Adicionalmente, a figura 48 mostra que os antofilita-Mg-cummingtonita xistos apresentam os mais elevados conteúdos de $\mathrm{Ni}$ (até 3162 ppm) e $\mathrm{Cr}_{2} \mathrm{O}_{3}$ (até 0,76\%), sem evidências de claro controle magmático.
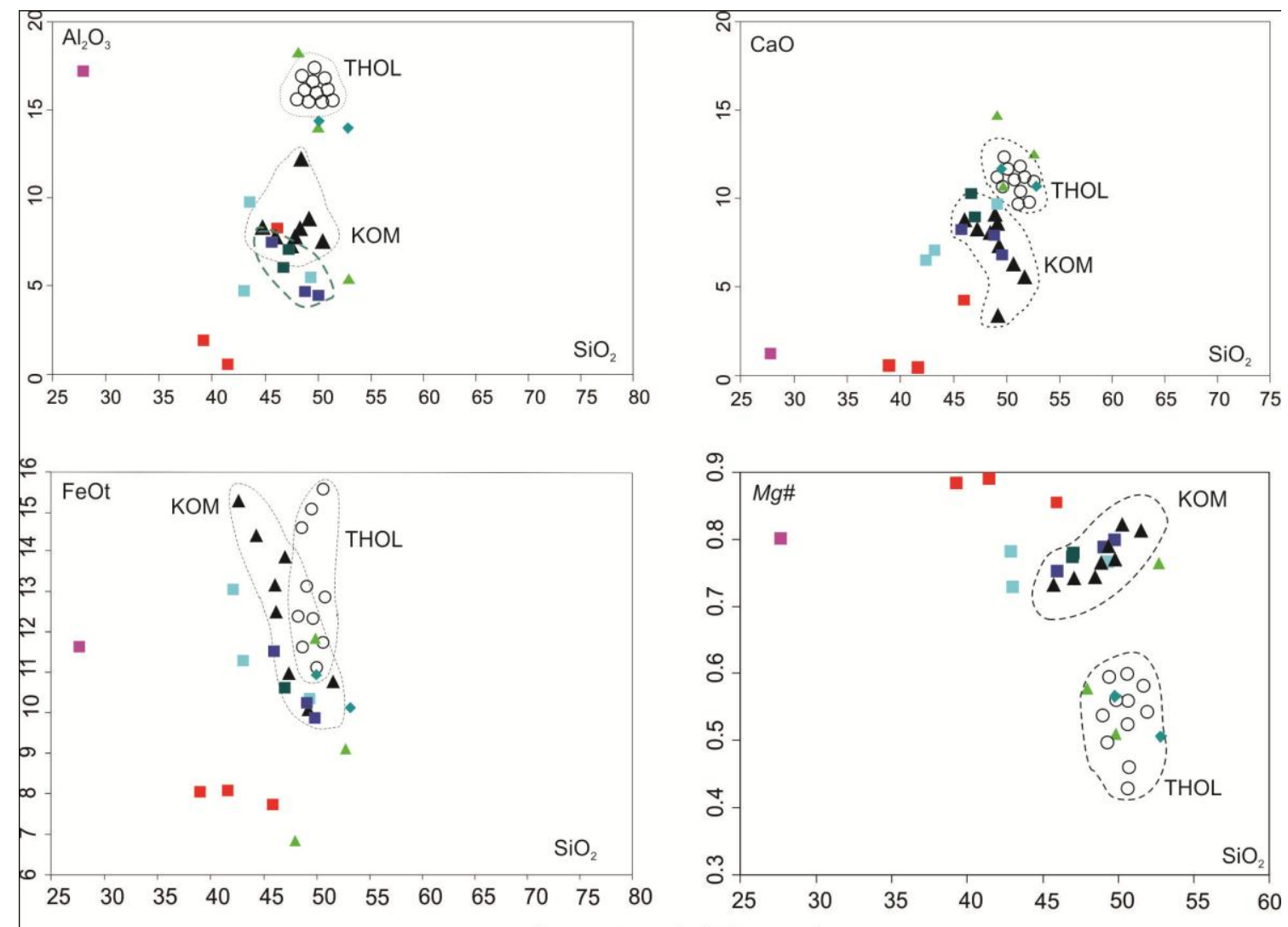

॥ (Mg) hornblenda anfibolitos Clorita-tremolita xistos

Greenstone belt Sapucaia

Figura 47. Diagramas de Harker, mostrando a relação entre conteúdo de $\mathrm{SiO}_{2}$ vs. óxidos de metabasitos e rochas metaultramáficas do Greenstone Belt Sapucaia e sua comparação com os campos dos basaltos tholeiíticos e komatiítos dos greenstone belts do Domínio Rio Maria, de acordo com Souza et al. (2001).

Zinco, $\mathrm{Y}$ e $\mathrm{Nd}$ apresentam grande variação nos litotipos metaultramáficos e aparentemente alguma correlação negativa com \#Mg pode ser observada apenas nos metabasitos (Fig. 48). Adicionalmente, os clorita-tremolita podem ser divididos em dois grupos (1a e 1b) que diferenciam-se por apresentar menores e maiores conteúdos desses elementos, respectivamente. 

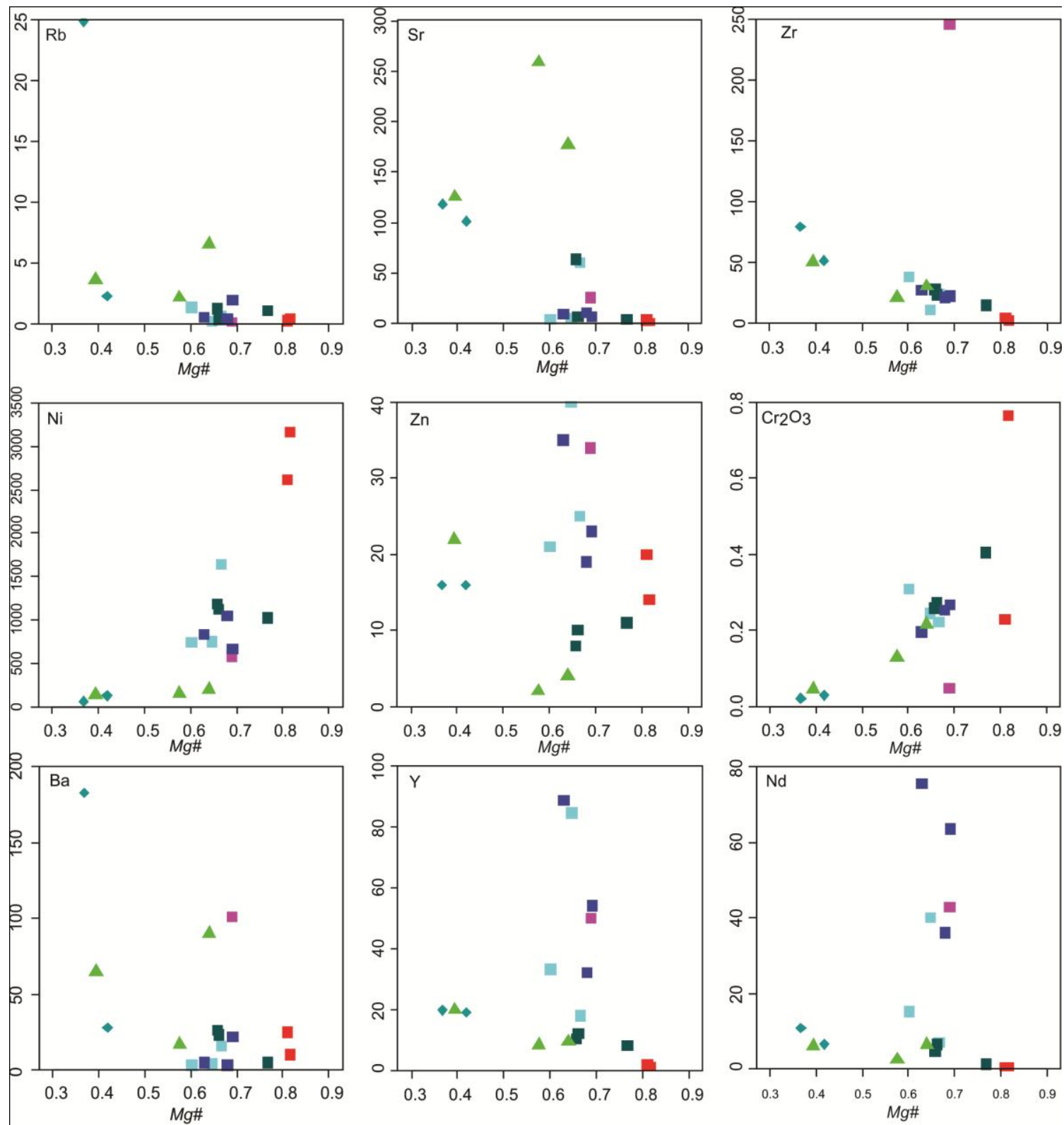

Greenstone belt Sapucaia

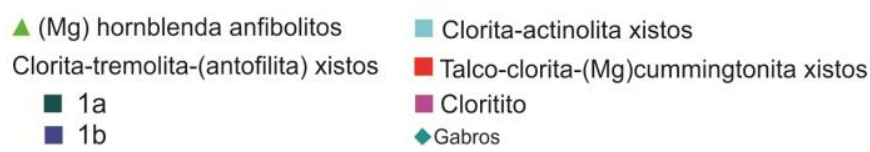

Figura 48. Diagramas de \#Mg vs. elementos traços para as rochas metabásicas e metaultramáficas do greenstone belt Sapucaia.

A correlação negativa entre $\mathrm{Zr}$ e \#Mg é claramente definida para o conjunto de amostras, exceto para o cloritito. Isso pode refletir que o $\mathrm{Zr}$, exceto no caso do cloritito, permaneceu relativamente imóvel, sendo sua distribuição controlada por processos ígneos, ao contrário do Y e ETRL, que podem ter sido relativamente mais móveis durante os processos metassomáticos pós-magmáticos.

Considerando-se o $\mathrm{Zr}$ relativamente imóvel e um índice de fracionamento, a observação das relações de $\mathrm{Zr}$ vs. óxidos (Fig. 49) e elementos traços (Fig. 50), também auxilia na avaliação relativa à mobilidade química durante os processos metassomáticos. 

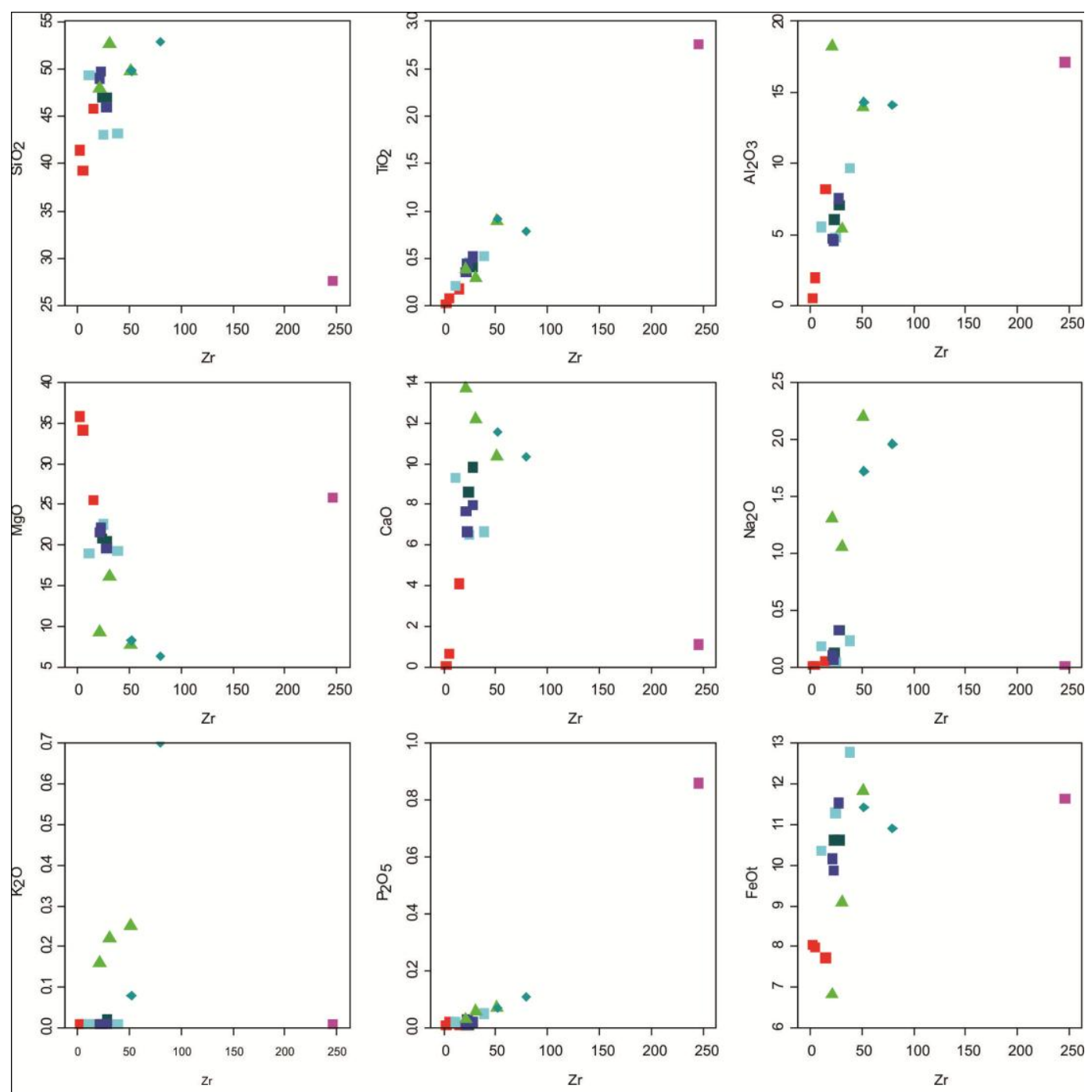

Greenstone belt Sapucaia

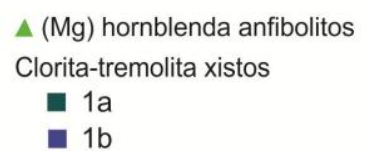

Clorita-actinolita xistos

- Antofilita-(Mg)cummingtonita xistos

Cloritito

$\bullet$ Gabros

Figura 49. Diagramas de Zr vs. elementos maiores (óxidos em \%) para as rochas metabásicas e metaultramáficas do greenstone belt Sapucaia.

A amostra de cloritito diferencia-se de todas as demais devido à intensidade dos processos metassomáticos. Nas demais amostras os elementos maiores e traços podem ser divididos em três grupos: (i) $\mathrm{TiO}_{2}, \mathrm{Al}_{2} \mathrm{O}_{3}, \mathrm{P}_{2} \mathrm{O}_{5}, \mathrm{Ga}, \mathrm{V}, \mathrm{Hf}$ - comportamento relativamente pouco móvel, exceto nos metabasitos; (ii) $\mathrm{MgO}, \mathrm{CaO}, \mathrm{FeOt}, \mathrm{Ni}, \mathrm{Cr}_{2} \mathrm{O}_{3}, \mathrm{Cu}, \mathrm{ETRP}, \mathrm{Y}, \mathrm{Nb}$ processos magmáticos exerceram controle importante nas suas variações, mas mobilidade relativa é verificada nas amostras de metabasitos e clorita-actinolito xistos; (iii) $\mathrm{SiO}_{2}, \mathrm{Na}_{2} \mathrm{O}$, $\mathrm{K}_{2} \mathrm{O}, \mathrm{Rb}, \mathrm{Ba}, \mathrm{Sr}, \mathrm{Zn}, \mathrm{Pb}, \mathrm{Ta}, \mathrm{ETRL}$ - componentes altamente móveis. 

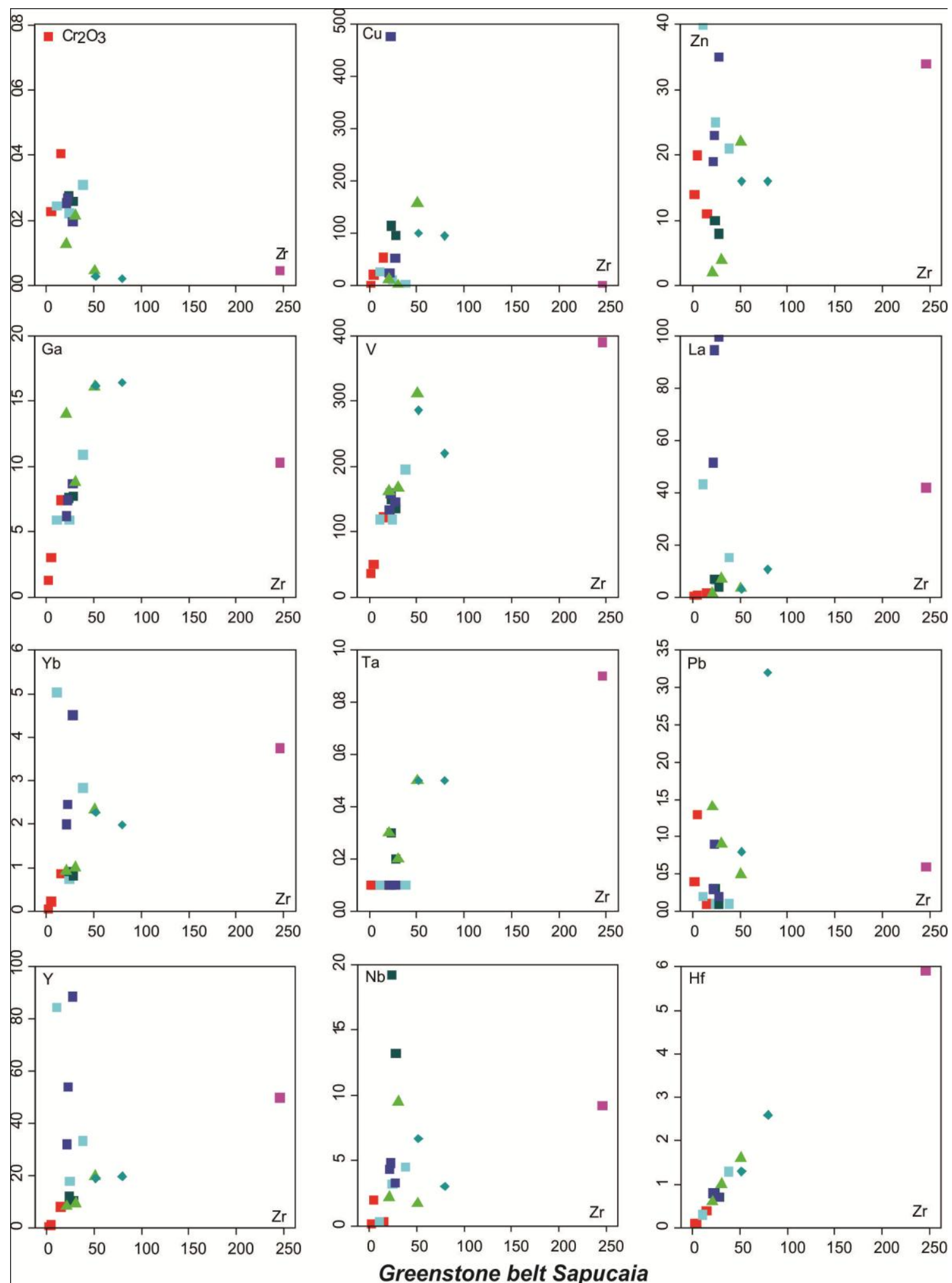

$\Delta$ (Mg) hornblenda anfibolitos

Clorita-tremolita xistos

- 1a

- 1b
Clorita-actinolita xistos

Antofilita-(Mg)cummingtonita xistos

- Cloritito

Gabros

Figura 50. Diagramas de $\mathrm{Zr} v$ s. elementos traços (ppm) para as rochas metabásicas e metaultramáficas do greenstone belt Sapucaia. 


\subsubsection{Elementos Traços e Terras raras}

As rochas metaultramáficas exibem uma grande variação em relação aos seus conteúdos de ETR (tabela 3), mostrando padrões de distribuição e anomalias diferentes.

Nos clorita-tremolita xistos, o conteúdo de ETR total varia de 25 a 267 ppm, mas a diferença entre os grupos 1a $\left(\Sigma_{\mathrm{ETR}}=25\right.$ a $\left.30 \mathrm{ppm}\right)$ e $1 \mathrm{~b}\left(\Sigma_{\mathrm{ETR}}=133\right.$ a $\left.267 \mathrm{ppm}\right)$ é notável. A distribuição dos ETR normalizados em relação ao condrito indica fracionamento dos ETRL em relação aos ETRP mais intenso no grupo $1 \mathrm{~b}\left(\mathrm{La} / \mathrm{Yb}_{\mathrm{N}}=14,92\right.$ a 26,$00 ; \mathrm{Gd} / \mathrm{Yb}_{\mathrm{N}}=2,35 \mathrm{a}$ $3,46)$ em relação ao grupo $1 \mathrm{a}\left(\mathrm{La} / \mathrm{Yb}_{\mathrm{N}}=3,01\right.$ a 4,$98 ; \mathrm{Gd} / \mathrm{Yb}_{\mathrm{N}}=2,19$ a 1,67$)$, assim como anomalias negativas de Ce muito mais pronunciada no grupo $1 \mathrm{~b}\left(\mathrm{Ce} / \mathrm{Ce}^{*}=0,05\right.$ a 0,09$)$. Anomalias negativas de $\mathrm{Eu}\left(\mathrm{Eu} / \mathrm{Eu}^{*}=0,78\right.$ a 0,99) são sutis à ausentes nesses litotipos (Fig. 51).

Embora os clorita-actinolita xistos apresentem valores de $\Sigma_{\mathrm{ETR}}$, em geral, menores (26 a 154 ppm) em relação ao grupo $1 \mathrm{~b}$ dos clorita-tremolita xistos, mostram enriquecimento em $\operatorname{ETRL}\left(\mathrm{La} / \mathrm{Yb}_{\mathrm{N}}=3,61\right.$ a 5,$83 ; \mathrm{Gd} / \mathrm{Yb}_{\mathrm{N}}=1,31$ a 2,49) e intensas anomalias negativas de $\mathrm{Ce}$ $\left(\mathrm{Ce} / \mathrm{Ce}^{*}=0,04\right.$ a 0,17) semelhantes às desse grupo (Fig. 51).

Os antofilita-Mg-cummingtonita xistos diferem de todos os demais litotipos ultramáficos devido aos valores muito mais baixos de $\Sigma_{\text {ETR }}(1$ a 10 ppm), menores em duas amostras que os do condrito, e fracionamento variável dos ETRL em relação aos ETRP $\left(\mathrm{La} / \mathrm{Yb}_{\mathrm{N}}=1,32\right.$ a 4,05). O clorito possui elevado valor de $\Sigma_{\mathrm{ETR}}(307,71 \mathrm{ppm})$, revela forte enriquecimento dos ETRL $\left(\mathrm{La} / \mathrm{Yb}_{\mathrm{N}}=7,52\right)$, ausência de anomalia significativa de $\mathrm{Ce}(\mathrm{Ce} / \mathrm{Ce} *$ $=0,95)$ e anomalia negativa de Eu pronunciada $\left(\mathrm{Eu} / \mathrm{Eu}^{*}=0,29\right)$.

Nos metabasitos, a variação dos valores de $\Sigma_{\text {ETR }}$ é menor (14 a 60 ppm) e o padrão de distribuição dos ETR é flat, sem fracionamento significativo de elementos terras raras leves em relação aos pesados $\left(\mathrm{La} / \mathrm{Yb}_{\mathrm{N}}=1,00\right)$, exceto em uma amostra de hornblenda anfibolito e de uma de gabro, que exibem valores de $\mathrm{La} / \mathrm{Yb}_{\mathrm{N}}$ de 4,70 e 3,61, respectivamente (Fig. 51). 


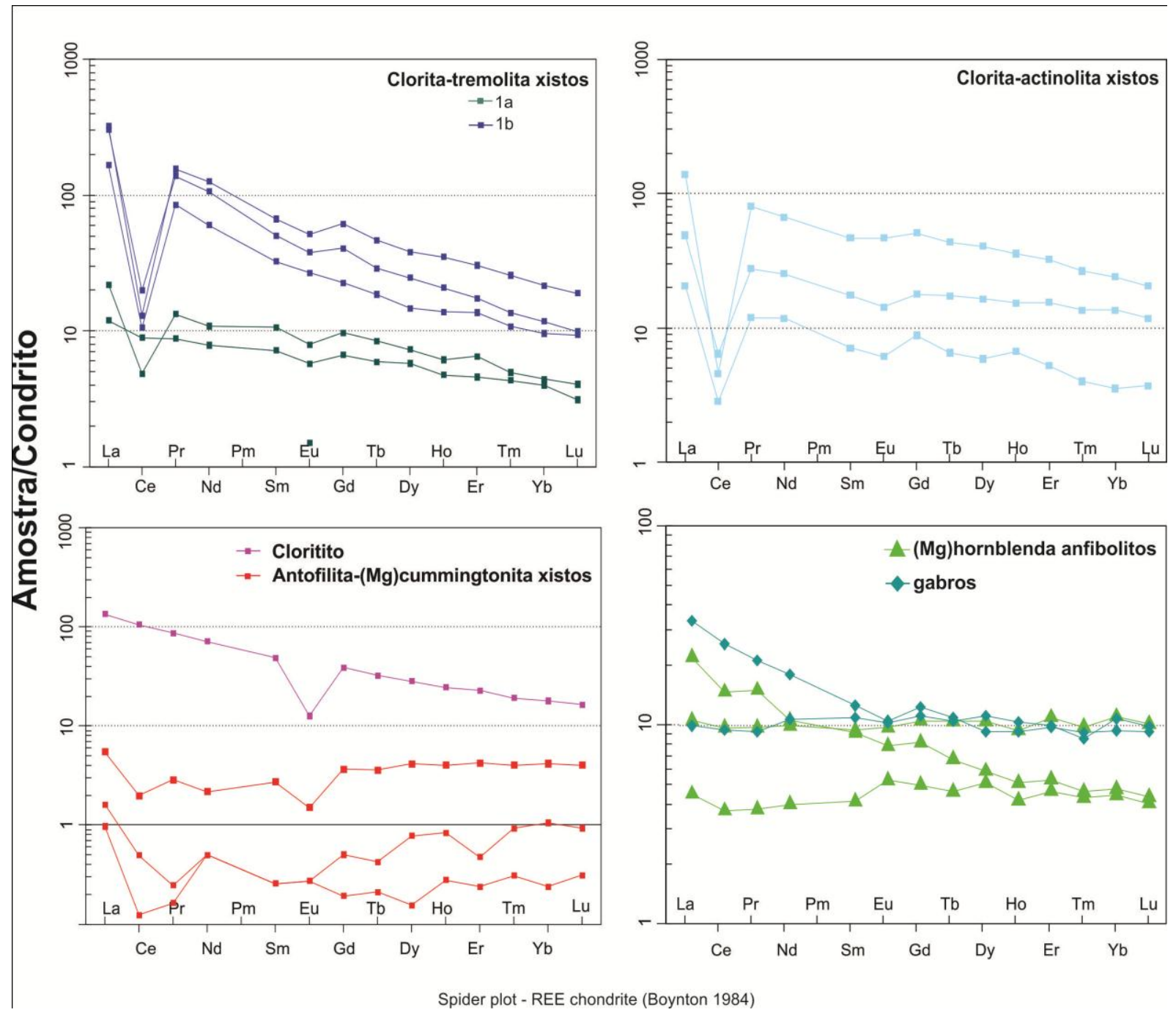

Figura 51. Distribuição de elementos terras raras normalizados em relação ao condrito (Boyton 1984) das rochas do greenstone belt Sapucaia.

Nos diagramas multi-elementares normalizados em relação ao manto primitivo (Sun \& McDonough 1989), os clorita-tremolita xistos pertencentes ao grupo 1a exibem anomalias negativas de $\mathrm{K}$ e $\mathrm{Sr}$ e positivas de $\mathrm{Nb}$ e $\mathrm{La}$. Os litotipos do grupo $1 \mathrm{~b}$ possuem anomalias negativas de $\mathrm{Rb}, \mathrm{Ba}, \mathrm{K}, \mathrm{Sr}$ e $\mathrm{P}$ e positivas de $\mathrm{Nb}$, ETR e Y, em relação ao manto primitivo. Os clorita-actinolita xistos, apresentam distribuição de elementos traços semelhante ao grupo 1b, entretanto uma mostra apresenta anomalia negativa de $\mathrm{Nb}$ e as demais anomalia positiva e anomalias de P não é reconhecida (Fig. 52).

Os antofilita-(Mg)cummingtonita xistos apresentam além dos baixos valores de ETR, menores que os do manto primitivo, anomalias negativas de $\mathrm{Sr}$ e $\mathrm{Nb}$ em duas amostras e positivas de $\mathrm{U}$ e $\mathrm{Pb}$. O cloritito também diferencia-se dos demais litotipos pelas anomalias positivas de $\mathrm{U}$ e Th. Uma amostra de rochas metamáfica também apresenta maiores conteúdos de U, Pb e Sr (Fig. 52). 

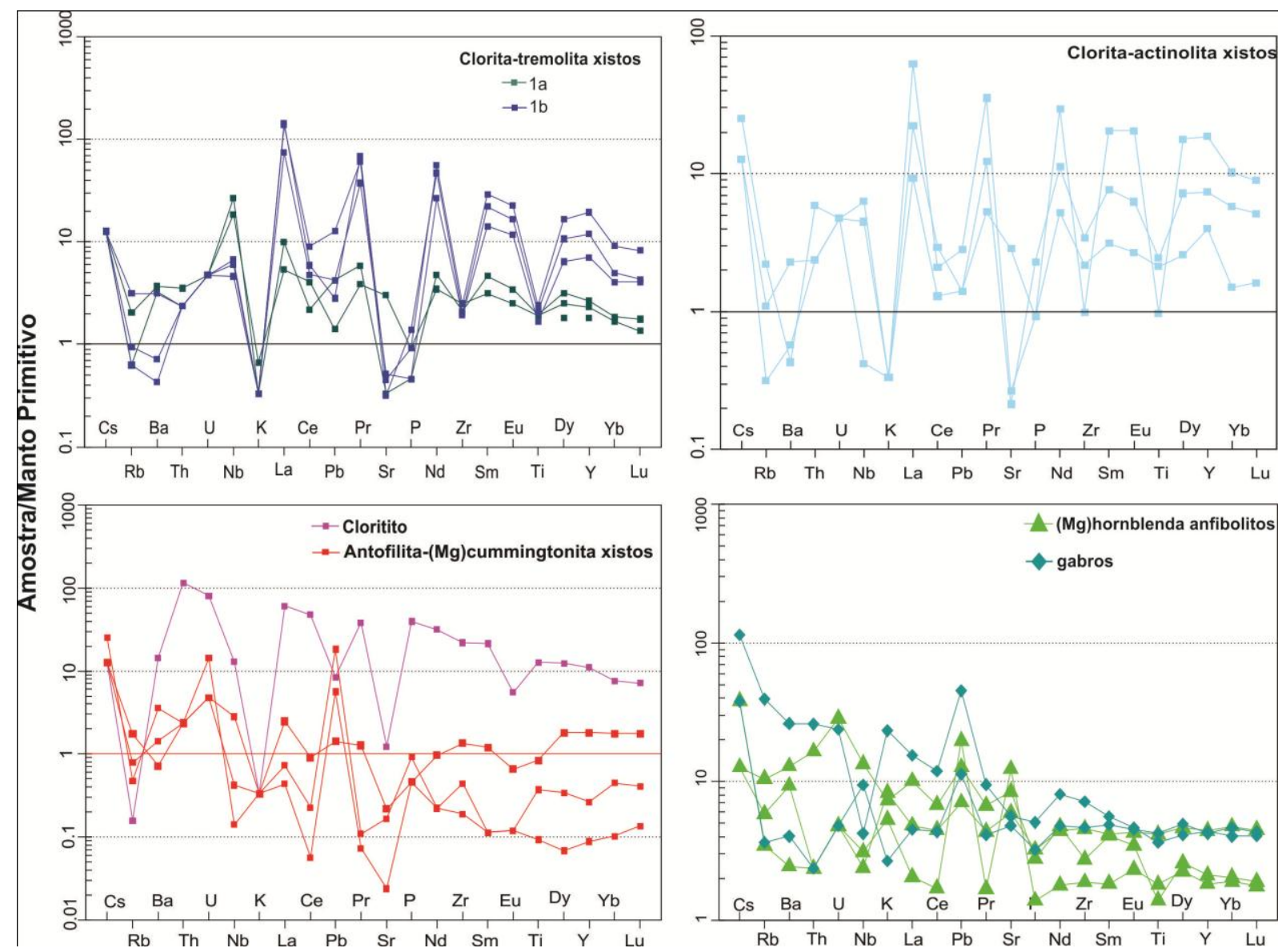

Figura 52. Padrões de distribuição de elementos traços incompatíveis normalizados em relação ao manto primitivo para as rochas metaultramáficas e máficas do greenstone belt Sapucaia, segundo Sun \& McDonough (1989).

Razões entre ETR e HFS (High field strength, tais como Nb, Ta, Zr, Hf, Ti) separam claramente os diferentes grupos de amostras (Fig. 53). Em relação aos clorita-tremolita xistos, o grupo 1 b distingue-se por apresentar os maiores valores de $(\mathrm{La} / \mathrm{Sm})_{\mathrm{N}}$ e $\mathrm{La} / \mathrm{Nb}$ e menores de $\mathrm{Sr} / \mathrm{Y}$, refletindo o maior enriquecimento em ETRL e Y desse grupo. Por sua vez, os valores da razão $\mathrm{La} / \mathrm{Nb}$ menor que 1 das amostras do grupo $1 \mathrm{a}$, pode refletir uma característica do magma original. Adicionalmente, as razões $(\mathrm{La} / \mathrm{Sm})_{\mathrm{N}}, \mathrm{Zr} / \mathrm{Y}$ e $\mathrm{La} / \mathrm{Nb}$ do grupo 1a são semelhantes às dos basaltos tholeiíticos menos metassomatisados, o que pode sugerir derivação de fontes mantélicas comuns.

Enquanto baixas razões $\mathrm{Nb} / \mathrm{Th}(<8)$ são indicativas de contaminação crustal, tanto as amostras do grupo $1 \mathrm{a}(\mathrm{Nb} / \mathrm{Th}=44$ a 96$)$ como $1 \mathrm{~b}(\mathrm{Nb} / \mathrm{Th}=16$ a 24) apresentam valores elevados, em decorrência de suas anomalias positivas de $\mathrm{Nb}$. As amostras com evidências de metassomatismo apresentam menores razões $\mathrm{Nb} / \mathrm{Th}$ (cloritito $=0,94$; antofilita-Mgcummingtonita xistos $=0,50$ a 10 ; clorita-actinolita xistos $=1,50$ a 16), revelando forte contribuição de componente crustal. 

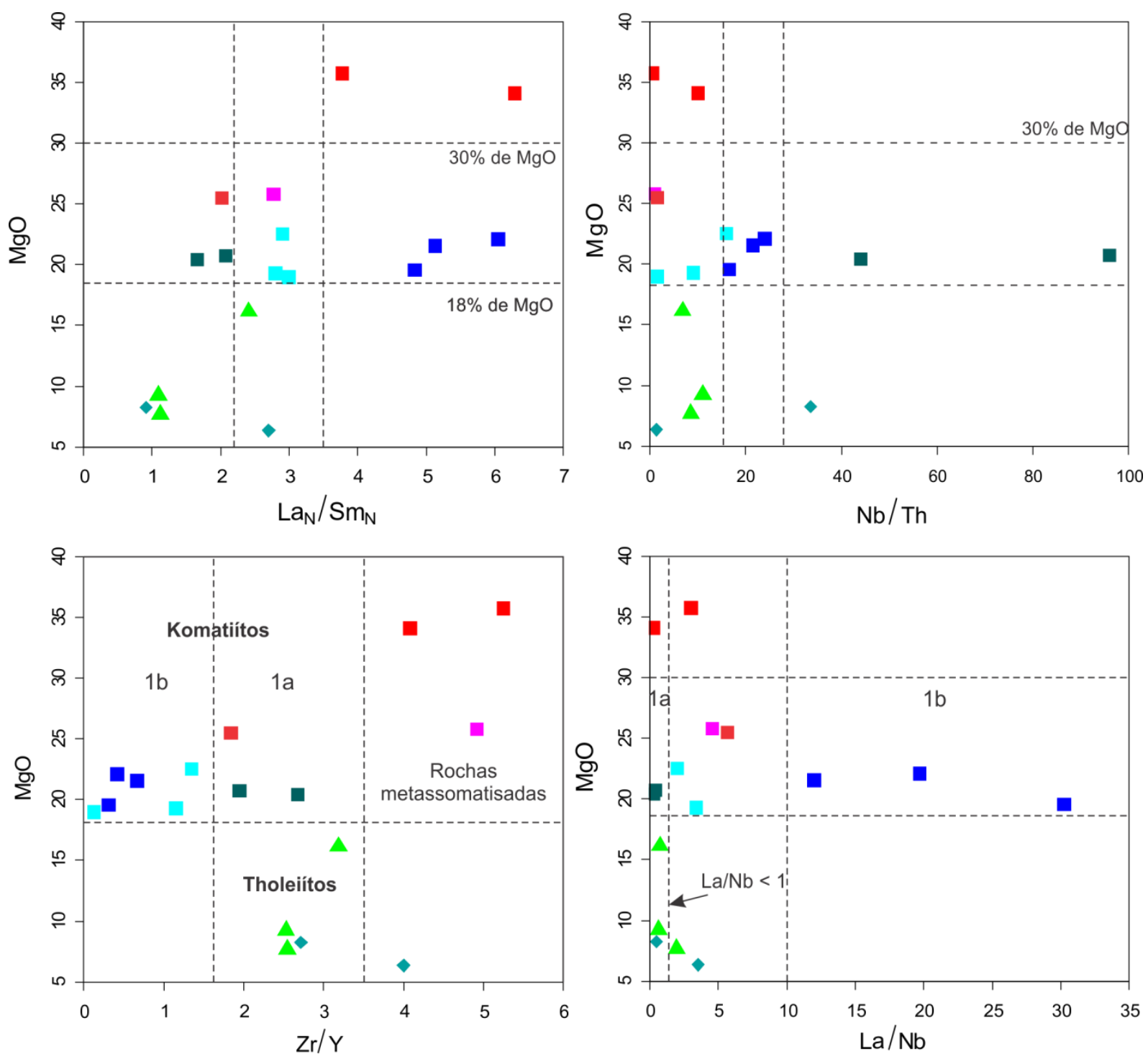

Greenstone belt Sapucaia

$\Delta(\mathrm{Mg})$ hornblenda anfibolitos

Clorita-tremolita xistos

- 1a

$1 \mathrm{~b}$
Clorita-actinolita xistos

- Antofilita-(Mg)cummingtonita xistos

- Cloritito

$\checkmark$ Gabros

Figura 53. Diagramas binários de $\mathrm{MgO}$ vs. $\left(\mathrm{La} / \mathrm{Sm}_{\mathrm{N}}\right), \mathrm{Nb} / \mathrm{Th}, \mathrm{Zr} / \mathrm{Y}$ e $\mathrm{La} / \mathrm{Nb}$ para metabasitos e rochas metaultramáficas do Greenstone Belt Sapucaia.

\subsubsection{Ambiente geotectônico de formação}

A classificação do ambiente geotectônico de rochas vulcânicas básicas e ultrabásicas foi realizada a partir do uso dos diagramas de Agrawal et al. (2008), que utilizam exclusivamente razões de elementos HFS ( $\mathrm{La}, \mathrm{Sm}, \mathrm{Yb}, \mathrm{Nb}$ e Th). Embora, a mobilidade relativa desses elementos tenha sido verificada, tanto as amostras do grupo 1a como as do grupo 1b dos clorita-tremolita xistos (Fig. 54) apresentam características comparáveis a de basaltos de ilha oceânica (OIB).

As amostras de clorita-actinolita xistos, no entanto, mostram maior dispersão, embora composição intermediária entre OIB e basaltos de dorsal meso-oceânicas (MORB) possa ser 
sugerida. As amostras de metabasitos plotam no campo dos MORB (Fig. 54). Por sua vez, as amostras de cloritito e antofilita-Mg-cumingtonita xistos revelam dispersão que pode ser atribuída ao metassomatismo e, portanto, os ambientes de arco de ilha - IAB (Basaltos de Arco de Ilha) e MORB, não devem refletir necessariamente o ambiente de formação de seus protólitos.
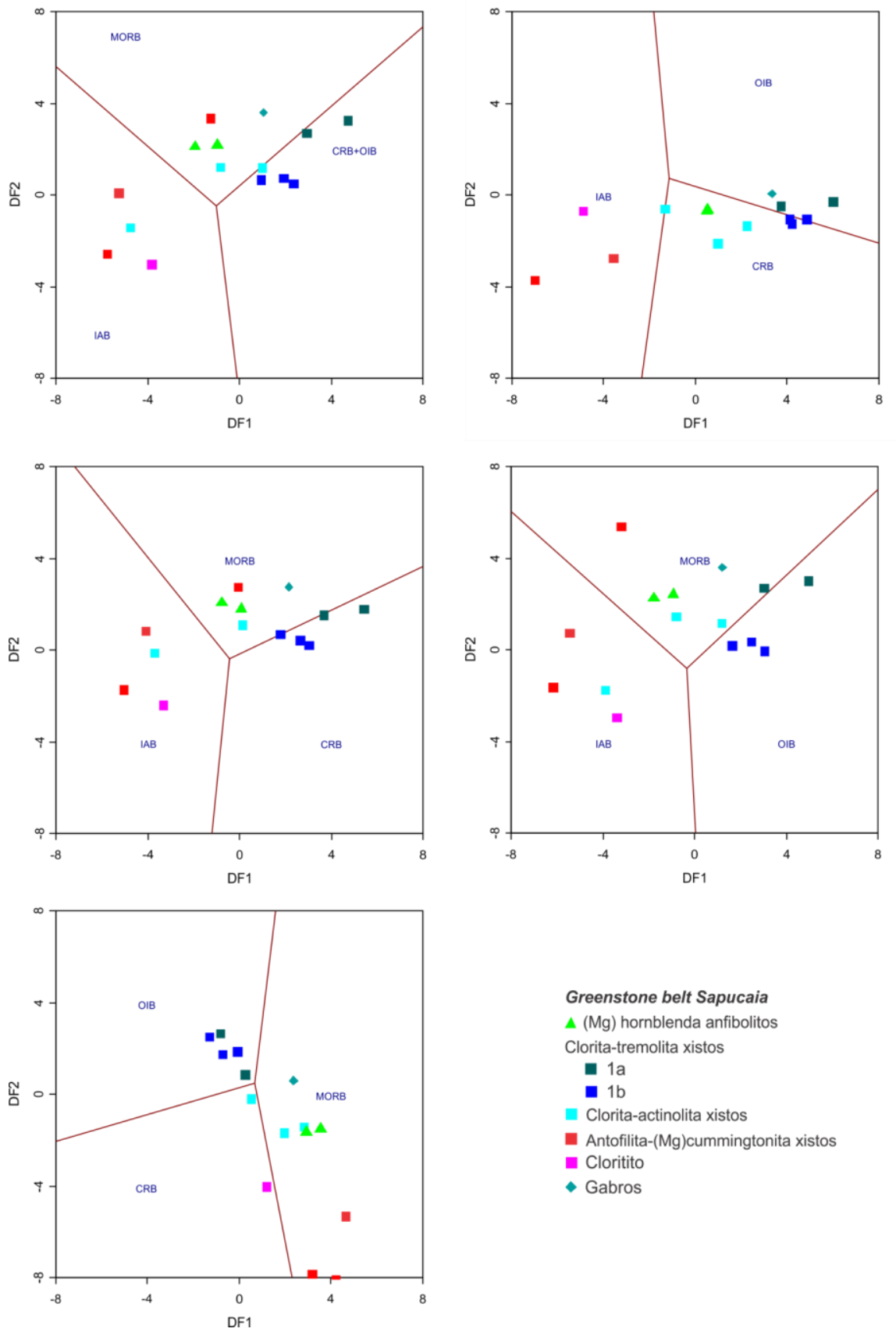

Greenstone belt Sapucaia

$\Delta(\mathrm{Mg})$ hornblenda anfibolitos

Clorita-tremolita xistos

- $1 \mathrm{a}$

- $1 \mathrm{~b}$

Clorita-actinolita xistos

- Antofilita-(Mg)cummingtonita xistos

- Cloritito

- Gabros

Figura 54. Diagramas para discriminação de ambiente geotectônico de rochas ultrabásicas e básicas, proposto por Agrawal et al. (2008), baseado nas razões log-transformadas $\ln (\mathrm{La} / \mathrm{Th}), \ln (\mathrm{Sm} / \mathrm{Th}), \ln (\mathrm{Yb} / \mathrm{Th})$ e $\ln$ $(\mathrm{Nb} / \mathrm{Th})$. 


\subsubsection{Cálculos de Balanço de Massa}

Balanço de massas foi realizado com o intuito de avaliar os processos metassomáticos e estimar ganhos e perdas a partir da identificação de elementos relativamente imóveis, assumindo-se que a mudança de volume foi um fator comum ao comportamento de todos os elementos (Gresens 1967; Grant 1986). A fórmula básica para os cálculos realizados é representada por:

$$
\mathbf{X}_{\mathbf{n}}=\left[\mathbf{f}_{\mathbf{v}}\left(\mathbf{g}^{\mathrm{B}} / \mathbf{g}^{\mathrm{A}}\right) \mathbf{C}^{\mathrm{B}}{ }_{\mathrm{N}}-\mathbf{C}^{\mathrm{A}}{ }_{\mathrm{n}}\right] \mathbf{a}, \text { onde: }
$$

$\boldsymbol{A}=$ amostra original inalterada, $\boldsymbol{B}=$ amostra final alterada, $\boldsymbol{n}=$ componente, $\boldsymbol{g}=$ gravidade especifica, $\boldsymbol{v}=$ volume da amostra, $\boldsymbol{f} \boldsymbol{v}=$ fator volumétrico, $\boldsymbol{a}=$ massa de referência $d a$ amostra original, $\boldsymbol{X}=$ perda ou ganho de massa de um componente em relação à massa de referência, $\boldsymbol{C}=$ concentração.

A partir desta equação podem ser identificados os elementos relativamente imóveis, que interceptam $\mathrm{Xn}=0$ próximo a um mesmo valor de fv (atribuído arbitrariamente e que representará o fator volumétrico da alteração). As mudanças de concentrações de elementos móveis podem então ser apresentadas em relação ao fator volumétrico.

O método gráfico de Grant (1986) representa a solução simultânea da equação de Gresens (1967) para todos os componentes, através da relação linear entre a concentração final da amostra alterada e a concentração original da amostra não alterada. Nesse método, todos os componentes que não apresentarem perdas ou ganhos de massa definem uma reta, a isocon que une pontos de igual concentração geoquímica antes e após a alteração. A inclinação desta reta define a mudança de massa na alteração e o desvio de um ponto da isocon define a mudança de concentração para o componente correspondente (Figura 55). Assim, a equação da reta isocon é:

$$
\mathbf{C}_{\mathbf{i}}^{\mathbf{A}}=\left(\mathbf{M}^{\mathbf{0}} / \mathbf{M}^{\mathrm{A}}\right) \mathbf{C}_{\mathbf{i}}^{\mathbf{o}} \text {, onde }
$$

$\boldsymbol{C}_{\boldsymbol{i}}^{\boldsymbol{A}}=$ concentração do elemento $i$ na amostra alterada, $\boldsymbol{C}_{\boldsymbol{i}}{ }^{\boldsymbol{D}}=$ concentração do elemento $i$ na amostra original; $\boldsymbol{M}^{\boldsymbol{0}}=$ massa inicial, $\boldsymbol{M}^{\boldsymbol{A}}=$ massa após alteração. 


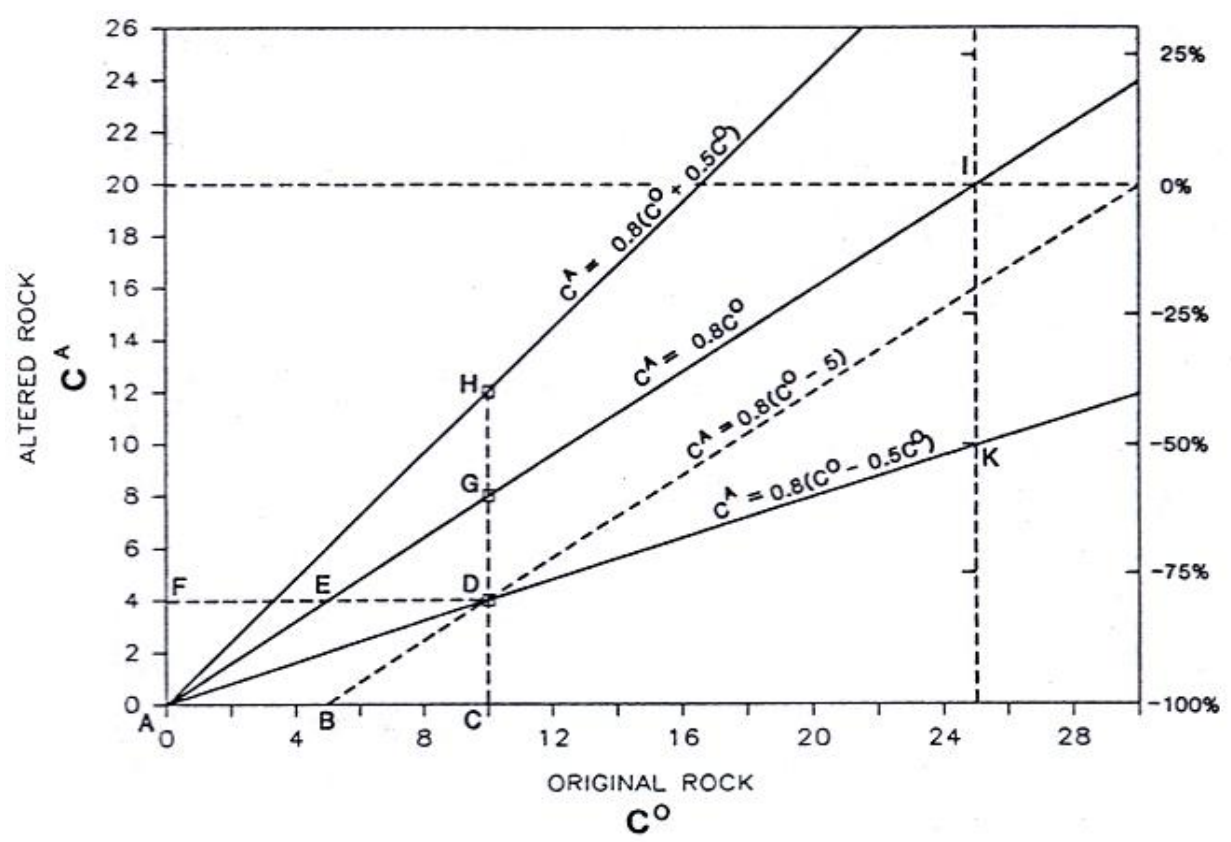

Figura 55. Ilustração apresentando a geometria básica do diagrama da isocon. A isocon corresponde a $\Delta \mathrm{Ci}=0$ e é designada nesse exemplo pela equação $\mathrm{CA}=0.8 \mathrm{Co}$. Todos os componentes para os quais $\Delta \mathrm{Ci}$ é constante são plotados numa linha paralela à isocon, como BD. Todos os componentes para os quais houve ganho ou perda de massa constante em relação à Co são plotados numa linha que passa pela origem, como $\mathrm{AD}$ ou $\mathrm{AH}$ (Grant, 1986).

A partir do gráfico, pode-se calcular o ganho e perda dos elementos de acordo com a fórmula abaixo (exemplo para o ponto D no gráfico da Figura 55 acima):

$$
\left(\Delta \mathrm{C}_{\mathrm{i}} / \mathrm{C}_{\mathrm{i}}{ }^{0}\right)=-(\mathrm{AB} / \mathrm{AC})=-(\mathrm{DG} / \mathrm{CG})
$$

Considerando-se que as amostras de clorita-actinolita xistos apresentam evidências de processos de metassomatismo, cálculos de balanço de massa foram realizados para avaliar as mudanças decorrentes desses processos considerando-se a amostra MCS16 (clorita-tremolita xisto) como equivalente ao seu protólito menos alterado. A equação que define a isocon $\left(\mathbf{C}_{\mathbf{i}}^{\mathbf{A}}=\right.$ $\mathbf{1 , 1 4} * \mathbf{C}_{\mathbf{i}}^{\mathbf{0}}$ ) considerando-se que o $\mathrm{TiO}_{2}$ teria sido relativamente imóvel nesse processo, indica perda de massa de aproximadamente 12\% (Fig. 56). As principais mudanças referem-se a perdas de $\mathrm{SiO}_{2}, \mathrm{CaO}, \mathrm{Na}_{2} \mathrm{O}, \mathrm{Co}, \mathrm{V}, \mathrm{Ga}, \mathrm{Cu}, \mathrm{Sr}, \mathrm{Rb}, \mathrm{Zr}, \mathrm{Nb}, \mathrm{Ba}$ e Ce e ganhos de $\mathrm{Ni}, \mathrm{Y}, \mathrm{Zn}$ e $\mathrm{La}$ (Tabela 4). 


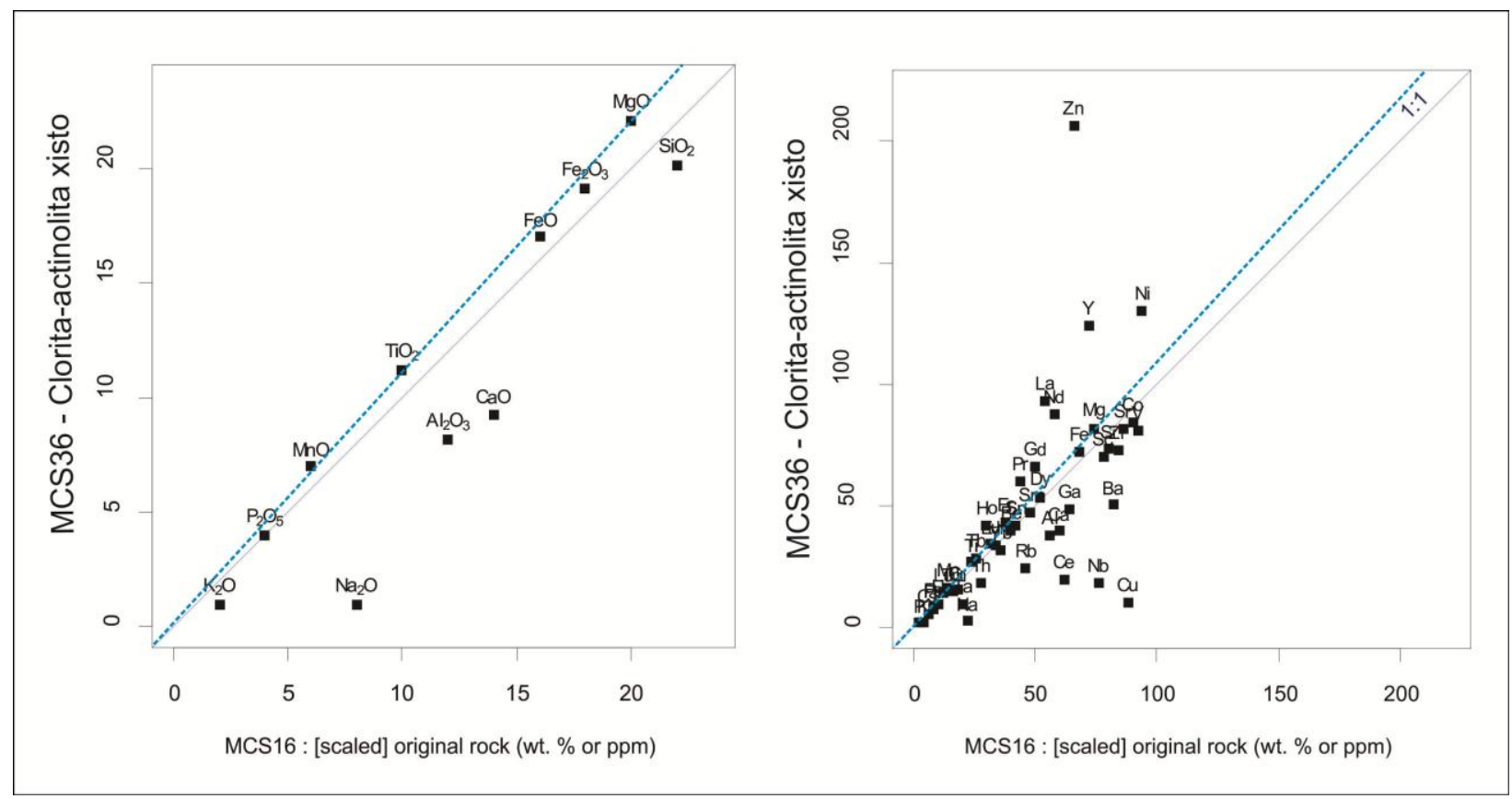

Figura 56. Diagramas Isocon (Grant, 1986) mostrando balanço de massa entre as amostras MCS16 (cloritatremolita xisto) e MCS36 (clorita-actinolita xisto).

Tabela 4. Cálculos de balanço de massa entre as amostras MCS16 (clorita-tremolita xisto) e MCL36 (cloritaactinolita xisto).

\begin{tabular}{|c|c|c|c|c|c|c|c|}
\hline & MCS16 & MCS36 & $\begin{array}{c}\text { Slope data } \\
\text { point }\end{array}$ & $\begin{array}{c}\text { G/L } \\
\text { rel,(LQ) }\end{array}$ & $\begin{array}{c}\text { G/L } \\
\text { rel,(avg) }\end{array}$ & $\begin{array}{c}\text { G/L } \\
\text { wt\%/ppm(LQ) }\end{array}$ & $\begin{array}{c}\text { G/L } \\
\text { wt\%/ppm(avg) }\end{array}$ \\
\hline $\mathrm{SiO}_{2}$ & 46.94 & 43.06 & 0.917 & -0.2 & -0.2 & -9.27 & -9.31 \\
\hline $\mathrm{TiO}_{2}$ & 0.41 & 0.46 & 1,122 & -0.02 & -0.02 & -0.01 & -0.01 \\
\hline $\mathrm{Al}_{2} \mathrm{O}_{3}$ & 7.07 & 4.83 & 0.683 & -0.4 & -0.4 & -2.84 & -2.85 \\
\hline $\mathrm{Fe}_{2} \mathrm{O}_{3}$ & 11.8 & 12.55 & 1,064 & -0.07 & -0.07 & -0.82 & -0.83 \\
\hline $\mathrm{FeO}$ & 10.62 & 11.29 & 1,064 & -0.07 & -0.07 & -0.74 & -0.75 \\
\hline $\mathrm{MnO}$ & 0.18 & 0.21 & 1,167 & 0.02 & 0.02 & 0 & 0 \\
\hline $\mathrm{MgO}$ & 20.41 & 22.55 & 1,105 & -0.03 & -0.03 & -0.68 & -0.7 \\
\hline $\mathrm{CaO}$ & 9.81 & 6.5 & 0.663 & -0.42 & -0.42 & -4.12 & -4.13 \\
\hline $\mathrm{Na}_{2} \mathrm{O}$ & 0.32 & 0.04 & 0.125 & -0.89 & -0.89 & -0.29 & -0.29 \\
\hline $\mathrm{K}_{2} \mathrm{O}$ & 0.02 & 0.01 & 0.5 & -0.56 & -0.56 & -0.01 & -0.01 \\
\hline $\mathrm{P}_{2} \mathrm{O}_{5}$ & 0.02 & 0.02 & 1,000 & -0.13 & -0.13 & 0 & 0 \\
\hline $\mathrm{Ni}$ & 1184 & 1639 & 1,384 & 0.21 & 0.21 & 249.71 & 248.31 \\
\hline $\mathrm{Cr}_{2} \mathrm{O}_{3}$ & 0.26 & 0.22 & 0.86 & -0.25 & -0.25 & -0.06 & -0.06 \\
\hline $\mathrm{Y}$ & 10.5 & 18.1 & 1,724 & 0.51 & 0.51 & 5.33 & 5.32 \\
\hline Co & 98.6 & 92.7 & 0.94 & -0.18 & -0.18 & -17.51 & -17.59 \\
\hline V & 135 & 119 & 0.881 & -0.23 & -0.23 & -30.91 & -31.01 \\
\hline $\mathrm{Ga}$ & 7.7 & 5.9 & 0.766 & -0.33 & -0.33 & -2.54 & -2.54 \\
\hline $\mathrm{Cu}$ & 95.8 & 11.2 & 0.117 & -0.9 & -0.9 & -86 & -86.01 \\
\hline $\mathrm{Zn}$ & 8 & 25 & 3,125 & 1.73 & 1.73 & 13.87 & 13.85 \\
\hline $\mathrm{Rb}$ & 1.3 & 0.7 & 0.538 & -0.53 & -0.53 & -0.69 & -0.69 \\
\hline $\mathrm{Sr}$ & 63.5 & 60.5 & 0.953 & -0.17 & -0.17 & -10.58 & -10.63 \\
\hline $\mathrm{Zr}$ & 28.1 & 24.4 & 0.868 & -0.24 & -0.24 & -6.76 & -6.78 \\
\hline $\mathrm{Nb}$ & 13.2 & 3.2 & 0.242 & -0.79 & -0.79 & -10.4 & -10.4 \\
\hline
\end{tabular}




\section{Continua}

\begin{tabular}{|c|c|c|c|c|c|c|c|}
\hline Cs & 0.1 & 0.1 & 1,000 & -0.13 & -0.13 & -0.01 & -0.01 \\
\hline $\mathrm{Ba}$ & 26 & 16 & 0.615 & -0.46 & -0.46 & -12 & -12.02 \\
\hline $\mathrm{La}$ & 3.7 & 6.4 & 1,730 & 0.51 & 0.51 & 1.9 & 1.89 \\
\hline $\mathrm{Ce}$ & 7.2 & 2.3 & 0.319 & -0.72 & -0.72 & -5.19 & -5.19 \\
\hline $\operatorname{Pr}$ & 1.07 & 1.46 & 1,364 & 0.19 & 0.19 & 0.21 & 0.21 \\
\hline $\mathrm{Nd}$ & 4.7 & 7.1 & 1,511 & 0.32 & 0.32 & 1.51 & 1.5 \\
\hline $\mathrm{Sm}$ & 1.4 & 1.39 & 0.993 & -0.13 & -0.13 & -0.18 & -0.19 \\
\hline $\mathrm{Eu}$ & 0.42 & 0.45 & 1,071 & -0.06 & -0.06 & -0.03 & -0.03 \\
\hline $\mathrm{Gd}$ & 1.72 & 2.28 & 1,326 & 0.16 & 0.16 & 0.27 & 0.27 \\
\hline $\mathrm{Tb}$ & 0.28 & 0.31 & 1,107 & -0.03 & -0.03 & -0.01 & -0.01 \\
\hline Dy & 1.85 & 1.9 & 1,027 & -0.1 & -0.1 & -0.19 & -0.19 \\
\hline Ho & 0.34 & 0.48 & 1,412 & 0.23 & 0.23 & 0.08 & 0.08 \\
\hline Er & 0.96 & 1.1 & 1,146 & 0 & 0 & 0 & 0 \\
\hline $\mathrm{Tm}$ & 0.14 & 0.13 & 0.929 & -0.19 & -0.19 & -0.03 & -0.03 \\
\hline $\mathrm{Yb}$ & 0.83 & 0.74 & 0.892 & -0.22 & -0.22 & -0.18 & -0.18 \\
\hline $\mathrm{Hf}$ & 0.7 & 0.7 & 1,000 & -0.13 & -0.13 & -0.09 & -0.09 \\
\hline $\mathrm{Ta}$ & 0.2 & 0.1 & 0.5 & -0.56 & -0.56 & -0.11 & -0.11 \\
\hline $\mathrm{Pb}$ & 0.1 & 0.1 & 1,000 & -0.13 & -0.13 & -0.01 & -0.01 \\
\hline Th & 0.3 & 0.2 & 0.667 & -0.42 & -0.42 & -0.13 & -0.13 \\
\hline $\mathrm{U}$ & 0.1 & 0.1 & 1,000 & -0.13 & -0.13 & -0.01 & -0.01 \\
\hline $\mathrm{Be}$ & 1 & 1 & 1,000 & -0.13 & -0.13 & -0.13 & -0.13 \\
\hline $\mathrm{Lu}$ & 0.1 & 0.12 & 1,200 & 0.05 & 0.05 & 0 & 0 \\
\hline $\mathrm{Sc}$ & 21 & 19 & 0.905 & -0.21 & -0.21 & -4.38 & -4.4 \\
\hline $\mathrm{Sn}$ & 1 & 1 & 1,000 & -0.13 & -0.13 & -0.13 & -0.13 \\
\hline
\end{tabular}

As mudanças foram mais intensas no cloritito, também comparado com a amostra MCS16 (clorita-tremolita xisto). A isocon $\left(\mathbf{C}_{\mathbf{i}}{ }^{\mathbf{A}}=\mathbf{4 , 5} \mathbf{C}_{\mathbf{i}}{ }^{\mathbf{0}}\right)$ definida considerando $\mathrm{TiO}_{2}$ e Cs como menos móveis reflete expressiva perda de massa (78\%; Figura 57). Nesse processo, os conteúdos muito mais elevados de $\mathrm{Al}_{2} \mathrm{O}_{3}$ do cloritito $(17,14 \%)$ em relação às demais rochas metaultramáficas não resulta de enriquecimento em $\mathrm{Al}_{2} \mathrm{O}_{3}$, mas de perda muito pequena $(0,47$; Tabela 5). As mudanças químicas mais expressivas referem-se aos ganhos em $\mathrm{P}_{2} \mathrm{O}_{5}, \mathrm{Zr}$, Th, $\mathrm{U}$ e ETRL e perdas de $\mathrm{SiO}_{2}, \mathrm{MgO}, \mathrm{MnO}, \mathrm{CaO}$, além de $\mathrm{Ni}, \mathrm{Cu}$, Co e V. 


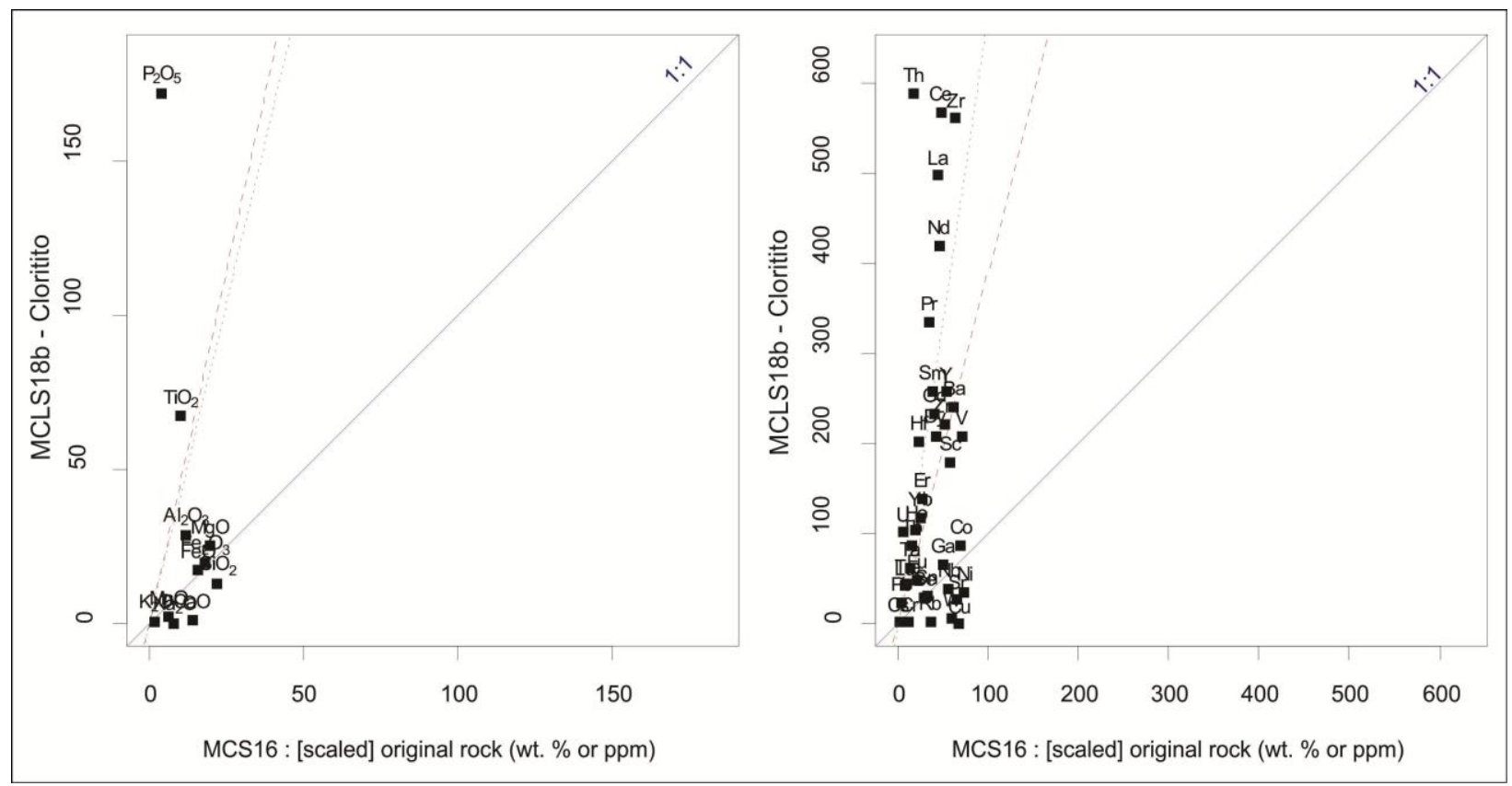

Figura 57. Diagramas Isocon (Grant, 1986) mostrando balanço de massa entre as amostras amostras MCS16 (clorita-tremolita xisto) e MCLS18b (cloritito).

Tabela 5. Cálculos de balanço de massa entre as amostras MCS16 (clorita-tremolita xisto) e MCLS18b (cloritito).

\begin{tabular}{|c|c|c|c|c|c|c|c|}
\hline & $\begin{array}{l}\text { MCS16 } \\
\text { Chl-Tr } \\
\text { xisto }\end{array}$ & $\begin{array}{l}\text { MCLS18d } \\
\text { Cloritito } \\
\end{array}$ & $\begin{array}{l}\text { Slope data } \\
\text { point }\end{array}$ & G/L rel.(LQ) & G/L rel.(avg) & $\begin{array}{l}\text { G/L wt \%/ppm } \\
\text { (LQ) }\end{array}$ & $\begin{array}{l}\text { G/L wt \%/ppm } \\
\text { (avg) }\end{array}$ \\
\hline $\mathrm{SiO}_{2}$ & 46.94 & 27.66 & 0.589 & -0.87 & -0.87 & -40.83 & -40.90 \\
\hline $\mathrm{TiO}_{2}$ & 0.41 & 2.76 & 6,732 & 0.49 & 0.47 & 0.20 & 0.19 \\
\hline $\mathrm{Al}_{2} \mathrm{O}_{3}$ & 7.07 & 17.14 & 2,424 & -0.46 & -0.47 & -3.28 & -3.33 \\
\hline $\mathrm{MnO}$ & 0.18 & 0.08 & 0.444 & -0.90 & -0.90 & -0.16 & -0.16 \\
\hline $\mathrm{MgO}$ & 20.41 & 25.82 & 1,265 & -0.72 & -0.72 & -14.71 & -14.77 \\
\hline $\mathrm{CaO}$ & 9.81 & 1.12 & 0.114 & -0.97 & -0.98 & -9.56 & -9.57 \\
\hline $\mathrm{Na}_{2} \mathrm{O}$ & 0.32 & 0.01 & 0.031 & -0.99 & -0.99 & -0.32 & -0.32 \\
\hline $\mathrm{K}_{2} \mathrm{O}$ & 0.02 & 0.01 & 0.500 & -0.89 & -0.89 & -0.02 & -0.02 \\
\hline $\mathrm{P}_{2} \mathrm{O}_{5}$ & 0.02 & 0.86 & 43,000 & 8.50 & 8.39 & 0.17 & 0.17 \\
\hline $\mathrm{Ni}$ & 1184.00 & 581.00 & 0.491 & -0.89 & -0.89 & -1055.63 & -1057.09 \\
\hline $\mathrm{Cr}_{2} \mathrm{O}_{3}$ & 0.26 & 0.05 & 0.182 & -0.96 & -0.96 & -0.25 & -0.25 \\
\hline $\mathrm{Y}$ & 10.50 & 50.00 & 4,762 & 0.05 & 0.04 & 0.55 & 0.42 \\
\hline Co & 98.60 & 123.40 & 1,252 & -0.72 & -0.73 & -71.34 & -71.65 \\
\hline V & 135.00 & 390.00 & 2,889 & -0.36 & -0.37 & -48.83 & -49.81 \\
\hline $\mathrm{Ga}$ & 7.70 & 10.30 & 1,338 & -0.70 & -0.71 & -5.42 & -5.45 \\
\hline $\mathrm{Cu}$ & 95.80 & 0.20 & 0.002 & -1.00 & -1.00 & -95.76 & -95.76 \\
\hline $\mathrm{Zn}$ & 8.00 & 34.00 & 4,250 & -0.06 & -0.07 & -0.49 & -0.57 \\
\hline $\mathrm{Rb}$ & 1.30 & 0.10 & 0.077 & -0.98 & -0.98 & -1.28 & -1.28 \\
\hline $\mathrm{Sr}$ & 63.50 & 25.90 & 0.408 & -0.91 & -0.91 & -57.78 & -57.84 \\
\hline $\mathrm{Zr}$ & 28.10 & 246.00 & 8,754 & 0.93 & 0.91 & 26.25 & 25.64 \\
\hline $\mathrm{Nb}$ & 13.20 & 9.20 & 0.697 & -0.85 & -0.85 & -11.17 & -11.19 \\
\hline Cs & 0.10 & 0.10 & 1,000 & -0.78 & -0.78 & -0.08 & -0.08 \\
\hline $\mathrm{Ba}$ & 26.00 & 101.00 & 3,885 & -0.14 & -0.15 & -3.69 & $\begin{array}{l}-3.94 \\
\text { Continua }\end{array}$ \\
\hline
\end{tabular}




\begin{tabular}{|c|c|c|c|c|c|c|c|}
\hline $\mathrm{La}$ & 3.70 & 41.80 & 11,297 & 1.50 & 1.47 & 5.54 & 5.43 \\
\hline $\mathrm{Ce}$ & 7.20 & 85.10 & 11,819 & 1.61 & 1.58 & 11.60 & 11.39 \\
\hline $\operatorname{Pr}$ & 1.07 & 10.53 & 9,841 & 1.17 & 1.15 & 1.26 & 1.23 \\
\hline $\mathrm{Nd}$ & 4.70 & 42.80 & 9,106 & 1.01 & 0.99 & 4.76 & 4.65 \\
\hline Sm & 1.40 & 9.49 & 6,779 & 0.50 & 0.48 & 0.70 & 0.67 \\
\hline $\mathrm{Eu}$ & 0.42 & 0.93 & 2,214 & -0.51 & -0.52 & -0.21 & -0.22 \\
\hline Gd & 1.72 & 10.05 & 5,843 & 0.29 & 0.28 & 0.50 & 0.48 \\
\hline $\mathrm{Tb}$ & 0.28 & 1.53 & 5,464 & 0.21 & 0.19 & 0.06 & 0.05 \\
\hline Dy & 1.85 & 9.15 & 4,946 & 0.09 & 0.08 & 0.17 & 0.15 \\
\hline Но & 0.34 & 1.76 & 5,176 & 0.14 & 0.13 & 0.05 & 0.04 \\
\hline $\mathrm{Er}$ & 0.96 & 4.77 & 4,969 & 0.10 & 0.09 & 0.09 & 0.08 \\
\hline $\mathrm{Tm}$ & 0.14 & 0.62 & 4,429 & -0.02 & -0.03 & 0.00 & 0.00 \\
\hline $\mathrm{Yb}$ & 0.83 & 3.75 & 4,518 & 0.00 & -0.01 & 0.00 & -0.01 \\
\hline Hf & 0.70 & 5.90 & 8,429 & 0.86 & 0.84 & 0.60 & 0.59 \\
\hline $\mathrm{Ta}$ & 0.20 & 0.90 & 4,500 & -0.01 & -0.02 & 0.00 & 0.00 \\
\hline $\mathrm{Pb}$ & 0.10 & 0.60 & 6,000 & 0.33 & 0.31 & 0.03 & 0.03 \\
\hline Th & 0.30 & 9.80 & 32,667 & 6.22 & 6.14 & 1.87 & 1.84 \\
\hline $\mathrm{U}$ & 0.10 & 1.70 & 17,000 & 2.76 & 2.71 & 0.28 & 0.27 \\
\hline $\mathrm{Be}$ & 1.00 & 1.00 & 1,000 & -0.78 & -0.78 & -0.78 & -0.78 \\
\hline $\mathrm{Lu}$ & 0.10 & 0.53 & 5,300 & 0.17 & 0.16 & 0.02 & 0.02 \\
\hline $\mathrm{Sc}$ & 21.00 & 65.00 & 3,095 & -0.32 & -0.32 & -6.64 & -6.80 \\
\hline Sn & 1.00 & 1.00 & 1,000 & -0.78 & -0.78 & -0.78 & -0.78 \\
\hline
\end{tabular}

\subsection{GEOQUÍMICA DAS ROCHAS GRANITOIDES}

As características geoquímicas dos granitóides analisados, que incluem: (a) biotita leucogranito; (b) anfibólio (hornblenda)-biotita granito foliado; (c) gnaisses: biotita gnaisse granítico biotita gnaisse granodiorítico e gnaisse granodiorítico milonitizado, são apresentadas na Tabela 6.

\subsubsection{Classificação geoquímica}

Os biotita gnaisses granodioríticos apresentam composições intermediárias entre tonalitos e granodioritos, de acordo com o gráfico Ab-An-Or (O’Connor 1965) da figura 58a, e composição próxima à trondjemítica no diagrama $\mathrm{Na}_{2} \mathrm{O}-\mathrm{K}_{2} \mathrm{O}-\mathrm{CaO}$ de Martin (1994; Fig. 58b). Esses litotipos são magnesianos (Fig. 59a), peraluminosos (Fig. 59b) e cálcicos a cálcico-alcalinos (Fig. 59b), de acordo com os critérios de Frost at al. (2001). Também apresentam tendência cálcio-alcalina no diagrama AFM de Irvine \& Baragar (1971; Fig. 59c).

O biotita gnaisse granítico foliado (msls14), apresenta composição granítica no diagrama Ab-An-Or normativo (O’Connor 1965; 1979; Fig. 58a), mas plota no limite do campo dos trondjemitos no diagrama K-Na-Ca de Martin (1994; Fig. 58b). O gnaisse 
milonitizado apresenta composição granodiorítica (Fig. 58a), caráter magnesiano (Fig. 59a) e peraluminoso (Fig. 59b) e tendência cálcio-alcalina (Fig. 59c), semelhante à dos biotita gnaisses granodioríticos.

O biotita leucogranito apresenta composição granítica (Fig. 59a) ou trondjemítica (Fig. 59b), caráter magnesiano, peraluminoso e tendência cálcio-alcalina, com composição próxima a dos granitos fortemente fracionados (Fig. 59a, 59b e 59d).

O anfibólio-biotita granito foliado apresenta composição granítica a quartzomonzonítica (Fig. 58a) e difere dos demais granitoides por ser ferroso (Fig. 59a), metaluminoso (Fig. 59b) e alcalino (Fig. 59d). No diagrama AFM de Irvine \& Baragar (1971; Fig. 59c), esse litotipo não se alinha à tendência cálcio-alcalina identificada para as demais amostras. Nos diagramas de Whalen et al. (1987), o anfibólio-biotita granito foliado plota no campo dos granitos tipo A, diferenciando-se dos demais que agrupam-se no campo dos granitos dos tipos I e S (Fig. 60).

\subsubsection{Elementos maiores e menores}

Em relação ao conteúdo de sílica, os granitoides apresentam diferenças significativas, variando de $59,12 \%$ a $72,25 \%$. As rochas que exibem texturas e característica ígneas são as que possuem o maior conteúdo de sílica $(72,25 \%$ no biotita leucogranito e $68,76 \%$ no biotitaanfibólio granito) em relação aos demais litotipos $(59,12 \%$ a $71,07 \%)$, que exibem texturas metamórficas e evidências de milonitização. Os conteúdos de $\mathrm{Na}_{2} \mathrm{O}$ são ligeiramente mais elevados no leucogranito $(4,89 \%)$ em relação aos biotita gnaisses $(4,34 \%$ a $4,4 \%)$, com exceção de uma amostra de biotita gnaisse granodiorítico, que possui conteúdo de $\mathrm{Na}_{2} \mathrm{O}$ de 5,28\%. Os valores de $\mathrm{Fe}_{2} \mathrm{O}_{3 \mathrm{~T}}(1,51 \%), \mathrm{MgO}(0,50 \%), \mathrm{CaO}(2,07 \%), \mathrm{TiO}_{2}(0,21 \%)$ e $\mathrm{P}_{2} \mathrm{O}_{5}$ $(0,07 \%$,$) são, em geral, menores no leucogranito em relação aos biotita gnaisses que$ apresentam intervalos de valores de $\mathrm{Fe}_{2} \mathrm{O}_{3}$ de 2,69 a 5,60\%, de $\mathrm{MgO}$ de 0,75\% a 3,03\%, de $\mathrm{CaO}$ de $2,32 \%$ a $6,28 \%$, de $\mathrm{TiO}_{2}$ de $0,29 \%$ a $0,75 \%$ e de $\mathrm{P}_{2} \mathrm{O}_{5}$ de $0,10 \%$ a $0,19 \%$, respectivamente. Entretanto, uma amostra de biotita gnaisse granítico (mscls26) apresenta conteúdos ainda menores desses óxidos que os do leucogranito (Tabela 6).

Os diagramas de Harker (Fig. 61) para os elementos maiores e menores em relação ao conteúdo de $\mathrm{SiO}_{2}$ mostram as diferentes composições dessas rochas. Em relação aos biotita gnaisses granodioríticos, uma amostra (mcls 03) milonitizada difere de todas as demais, devido aos seus conteúdos mais baixos de $\mathrm{SiO}_{2}$ e mais elevados de $\mathrm{Al}_{2} \mathrm{O}_{3}$ e $\mathrm{TiO}_{2}$. O anfibóliobiotita granito foliado apresenta conteúdo de sílica em 68,76\%, abaixo das demais amostras de composição granodiorítica, porém apresenta valores de $\mathrm{K}_{2} \mathrm{O}(3,78 \%)$, acima de todas as 
outras amostras e contéudo de $\mathrm{Fe}_{2} \mathrm{O}_{3}(5,47 \%)$ equiparável a amostra do Gnaisse Granodiorito Milonitizado (5,6\%).

Tabela 6. Composições químicas representativas dos granitoides da área de estudo.

\begin{tabular}{|c|c|c|c|c|c|c|c|}
\hline AMOSTRA & MCLS 01 & MCLS 03 & MCLS 07 & MCS17 & MCLS 14 & MCLS 24c & MCLS 26 \\
\hline UNIDADE & $\begin{array}{c}\text { Biotita } \\
\text { Leucogranito }\end{array}$ & Biotit: & Gnaisse Gra & liorito & $\begin{array}{l}\text { Anf-bt- } \\
\text { Granito } \\
\text { Foliado }\end{array}$ & $\begin{array}{c}\text { Gnaisse } \\
\text { Granodiorito } \\
\text { Milonitizado }\end{array}$ & $\begin{array}{c}\text { Biotita } \\
\text { granodiorito } \\
\text { Gnaisse }\end{array}$ \\
\hline $\mathrm{SiO}_{2}$ & 72,25 & 59,12 & 71,07 & 70,11 & 68,76 & 67,19 & 70,54 \\
\hline $\mathrm{TiO}_{2}$ & 0,21 & 0,72 & 0,29 & 0,38 & 0,75 & 0,35 & 0,13 \\
\hline $\mathrm{Al}_{2} \mathrm{O}_{3}$ & 14,94 & 20,06 & 15,29 & 15,7 & 13,14 & 14,02 & 16,36 \\
\hline $\mathrm{Fe}_{2} \mathrm{O}_{3}$ & 1,51 & 4,35 & 2,69 & 2,91 & 5,47 & 5,60 & 1,19 \\
\hline $\mathrm{MnO}$ & 0,02 & 0,07 & 0,04 & 0,03 & 0,06 & 0,02 & 0,02 \\
\hline $\mathrm{MgO}$ & 0,50 & 2,64 & 0,86 & 1 & 0,75 & 3,03 & 0,37 \\
\hline $\mathrm{CaO}$ & 2,07 & 6,28 & 3,61 & 3,89 & 2,56 & 2,33 & 1,92 \\
\hline $\mathrm{Na}_{2} \mathrm{O}$ & 4,89 & 4,34 & 4,36 & 4,4 & 3,35 & 3,32 & 5,28 \\
\hline $\mathrm{K}_{2} \mathrm{O}$ & 2,60 & 1,42 & 1,1 & 0,91 & 3,78 & 2,84 & 3,28 \\
\hline $\mathrm{P}_{2} \mathrm{O}_{5}$ & 0,07 & 0,19 & 0,1 & 0,1 & 0,16 & 0,15 & 0,08 \\
\hline LOI & 0,7 & 0,6 & 0,4 & 0,4 & 0,8 & 0,9 & 0,5 \\
\hline Total & 99,76 & 99,79 & 99,81 & 99,83 & 99,58 & 99,75 & 99,67 \\
\hline $\mathrm{Ba}$ & 1019 & 453 & 374 & 480 & 1765 & 383 & 1602 \\
\hline $\mathrm{Rb}$ & 64 & 51,4 & 34,7 & 34 & 65,3 & 137,9 & 91 \\
\hline $\mathrm{Sr}$ & 600,0 & 463,6 & 232,7 & 451,2 & 258,6 & 383,6 & 884,5 \\
\hline $\mathrm{Zr}$ & 94,1 & 141,9 & 140,3 & 96,6 & 696,7 & 123,1 & 71,5 \\
\hline $\mathrm{Nb}$ & 4,4 & 5,9 & 4,5 & 9,5 & 15,3 & 4,7 & 2,5 \\
\hline $\mathrm{Y}$ & 5,1 & 16,1 & 8,4 & 2,3 & 42,7 & 11,4 & 3,9 \\
\hline $\mathrm{Ga}$ & 18,1 & 18,7 & 17,8 & 18,1 & 18,8 & 15,4 & 18,9 \\
\hline $\mathrm{Pb}$ & 10 & 2,1 & 2,7 & 0,8 & 3,9 & 4,8 & 4,8 \\
\hline V & 14 & 111 & 24 & 49 & 39 & 59 & 8 \\
\hline $\mathrm{La}$ & 17,2 & 22,9 & 36,1 & 26,5 & 42,2 & 38,7 & 11,4 \\
\hline $\mathrm{Ce}$ & 33,4 & 45,3 & 69,2 & 35,3 & 97 & 67,2 & 22,5 \\
\hline $\operatorname{Pr}$ & 3,76 & 5,25 & 7,19 & 4,04 & 13,07 & 7,27 & 2,62 \\
\hline $\mathrm{Nd}$ & 14,5 & 21,0 & 22,6 & 13,2 & 55,3 & 27,3 & 10,0 \\
\hline $\mathrm{Sm}$ & 2,18 & 3,62 & 3,41 & 1,37 & 10,71 & 4,05 & 1,75 \\
\hline $\mathrm{Eu}$ & 0,60 & 1,04 & 0,82 & 0,53 & 1,86 & 1,18 & 0,51 \\
\hline $\mathrm{Gd}$ & 1,69 & 3,71 & 2,49 & 0,91 & 10,02 & 3,28 & 1,52 \\
\hline $\mathrm{Tb}$ & 0,18 & 0,51 & 0,3 & 0,08 & 1,46 & 0,42 & 0,18 \\
\hline Dy & 0,90 & 3,02 & 1,67 & 0,41 & 8,37 & 2,12 & 0,90 \\
\hline Ho & 0,17 & 0,57 & 0,27 & 0,08 & 1,60 & 0,36 & 0,14 \\
\hline $\mathrm{Er}$ & 0,39 & 1,70 & 0,67 & 0,17 & 4,47 & 0,96 & 0,35 \\
\hline $\mathrm{Tm}$ & 0,07 & 0,27 & 0,11 & 0,03 & 0,59 & 0,14 & 0,04 \\
\hline $\mathrm{Yb}$ & 0,37 & 1,61 & 0,81 & 0,24 & 3,51 & 0,77 & 0,20 \\
\hline $\mathrm{Th}$ & 3,4 & 4,6 & 7,8 & 3 & 1,9 & 19,2 & 4,3 \\
\hline $\mathrm{U}$ & 1,1 & 0,9 & 0,6 & 0,1 & 0,5 & 4,5 & 1,3 \\
\hline $\mathrm{Lu}$ & 0,06 & 0,26 & 0,12 & 0,02 & 0,50 & 0,11 & 0,04 \\
\hline$\Sigma$ REE & 79,97 & 116,26 & 154,16 & 85,98 & 252,86 & 177,56 & 57,75 \\
\hline $\mathrm{K}_{2} \mathrm{O} / \mathrm{Na}_{2} \mathrm{O}$ & 0,53 & 0,33 & 0,25 & 0,21 & 1,13 & 0,86 & 0,62 \\
\hline $\mathrm{Rb} / \mathrm{Sr}$ & 0,11 & 0,10 & 0,14 & 0,08 & 0,25 & 0,35 & 0,10 \\
\hline $\mathrm{Sr} / \mathrm{Y}$ & 117,6 & 28,79 & 27,7 & 196,17 & 6,05 & 33,64 & 226,8 \\
\hline $\mathrm{La} / \mathrm{Yb}$ & 477,14 & 14,22 & 44,57 & 110,42 & 12,02 & 50,26 & 57 \\
\hline$M g \#$ & 0,4 & 0,55 & 0,39 & 0,41 & 0,21 & 0,52 & 0,38 \\
\hline $\begin{array}{c}\mathrm{FeOt} /(\mathrm{FeOt}+ \\
\mathrm{MgO})\end{array}$ & 0,73 & 0,34 & 0,61 & 0,58 & 0,64 & 0,31 & 0,79 \\
\hline$(\mathrm{La} / \mathrm{Yb}) \mathrm{N}$ & 31,34 & 9,59 & 30,05 & 74,44 & 8,11 & 33,88 & 38,43 \\
\hline $\mathrm{Eu} / \mathrm{Eu}^{*}$ & 0,96 & 0,87 & 0,86 & 1,45 & 0,55 & 0,99 & 0,96 \\
\hline $\mathrm{A} / \mathrm{CNK}$ & 1,02 & 1 & 1,02 & 1,02 & 0,92 & 1,09 & 1,04 \\
\hline
\end{tabular}




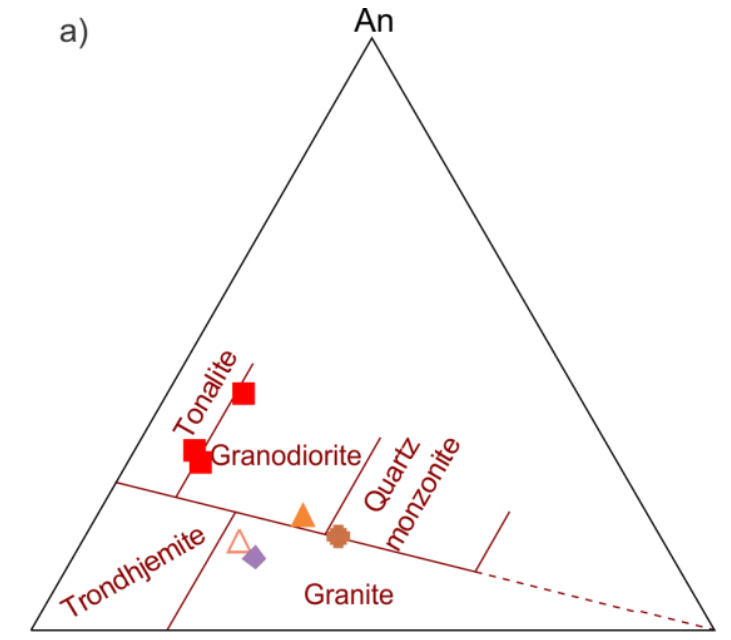

$\mathrm{Ab}$
Or

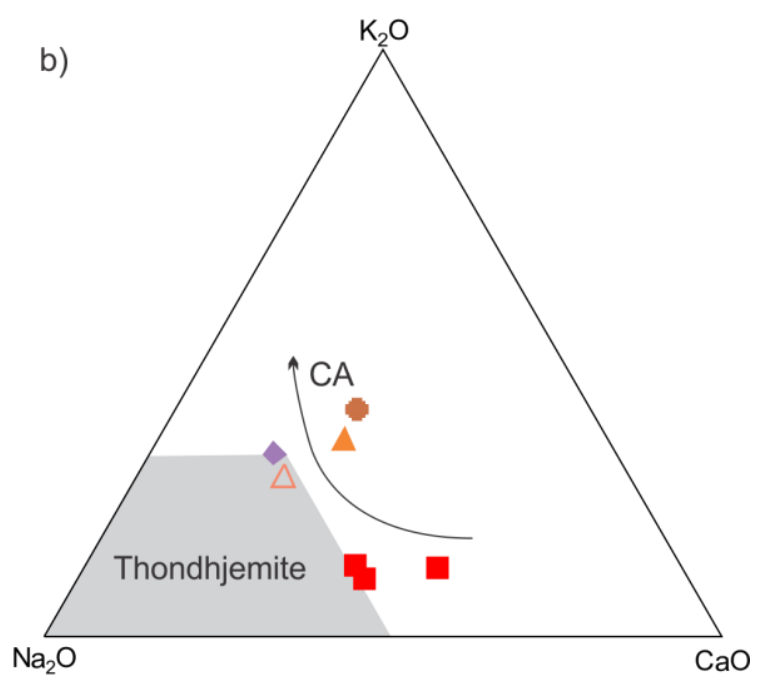

Biotita gnaisse granodiorítico

Biotita gnaisse granítico
Gnaisse granodiorítico milonitizado

Figura 58. Diagramas geoquímicos mostrando a distribuição dos granitoides: (a) diagrama Ab-An-Or normativo (O’Connor 1965 com campos de Barker 1976); (b) diagrama K-Na-Ca com tendências para as rochas cálcioalcalina (CA) com o campo dos Trondhjemitos (Martin 1994).
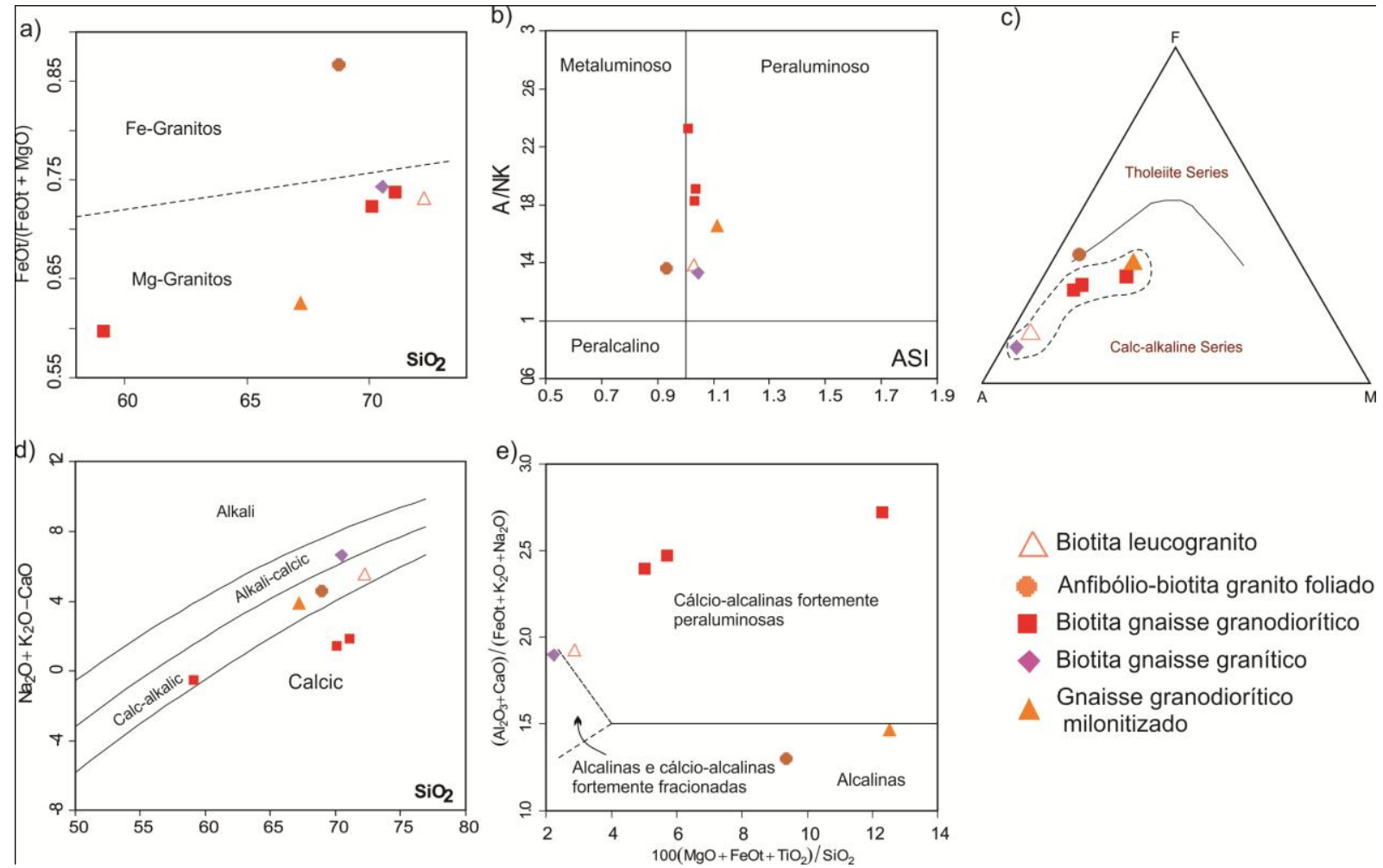

Biotita leucogranito

Anfibólio-biotita granito foliado

Biotita gnaisse granodiorítico

- Biotita gnaisse granítico

Gnaisse granodiorítico milonitizado

Figura 59. Diagramas geoquímicos mostrando a distribuição dos gnaisses e granitos: (a) diagrama $\mathrm{SiO}_{2}$ vs $\mathrm{FeO} /(\mathrm{FeO}+\mathrm{MgO})$ de Frost et al. (2001) para granitos ferrosos ou magnesianos; (B) diagrama ASI vs. A/NK de Frost et al. (2001); (c) diagrama AFM $\left(\mathrm{A}=\mathrm{Na}_{2} \mathrm{O}+\mathrm{K}_{2} \mathrm{O} ; \mathrm{F}=\mathrm{FeO}+0,9 * \mathrm{Fe}_{2} \mathrm{O}_{3} ; \mathrm{M}=\mathrm{MgO}\right)$ de Irvine \& Baragar (1971); (d) Digrama $\mathrm{SiO}_{2}$ vs. $\mathrm{Na}_{2} \mathrm{O}+\mathrm{K}_{2} \mathrm{O}+\mathrm{CaO}$; (e) diagrama de discriminação dos elementos maiores para leucogranitos (Sylvester 1989). 

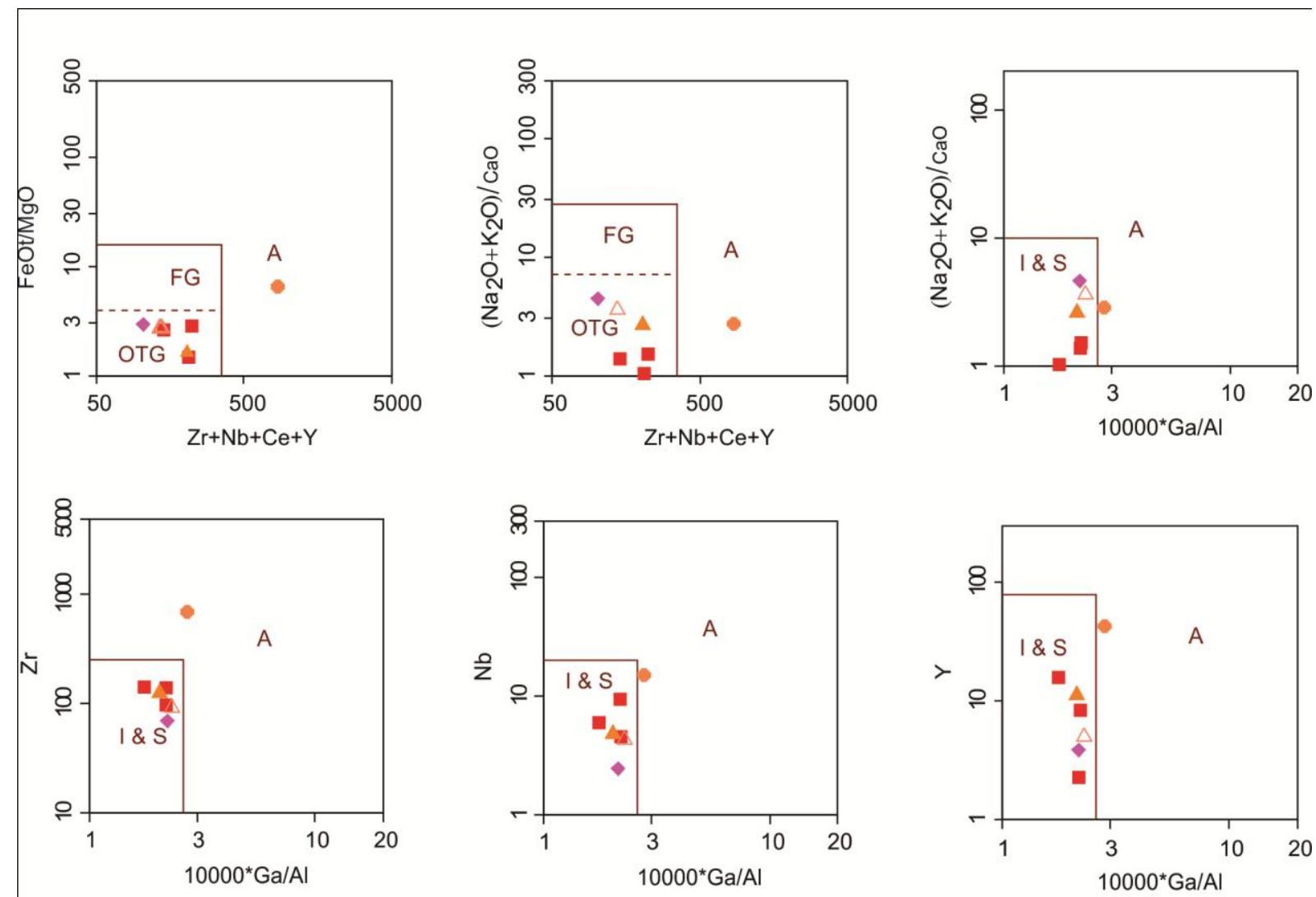

Biotita leucogranito

Anfibólio-biotita granito foliado

Biotita gnaisse granodiorítico Biotita gnaisse granítico

Gnaisse granodiorítico milonitizado

Figura 60. Diagramas de Whalen et al. (1987) para distinção entre granitos dos tipos A e I \& S, mostrando a classificação dos gnaisses e granitos da área de Água Azul do Norte.

\subsubsection{Elementos traços e Terras raras}

No que diz respeito aos elementos traços, conteúdos maiores de $\mathrm{Zr}$ (696,7 ppm), Nb (15,3 ppm), Ba (1765 ppm) e Y (42,7 ppm) distinguem o anfibólio-biotita granito foliado dos demais litotipos. Esse litotipo também apresenta conteúdos relativamente baixos de $\mathrm{Rb}$ e $\mathrm{Sr}$ (Fig. 62). O gnaisse granodiorítico milonitizado também apresenta conteúdo mais elevado de $\mathrm{Rb}(137,9$ ppm), em relação às demais rochas $(\mathrm{Rb}=34$ a 91 ppm).

Os diagramas binários de Harker (Fig. 62) para os elementos traços, de forma geral, não mostram correlações negativas ou positivas. $\mathrm{O}$ diagrama $\mathrm{Zr}$ vs. $\mathrm{Rb} / \mathrm{Sr}$ mostra espalhamento dos valores das razões $\mathrm{Rb} / \mathrm{Sr}$ nos biotita gnaisse granodioríticos (Fig. 63) e valor mais elevado dessa razão para a amostra de gnaisse milonitizado, indicando mobilidade desses elementos associada ao cisalhamento. As significativas variações na razão Sr/Y e La/Y podem indicar diferenças de profundidade de geração de magmas ou diferenças na composição de magmas fonte (Moyen \& Martin 2012) que geraram os protólitos dos gnaisses, ou ainda, mobilidade de Sr e/ou ETRL devido aos processos pós-magmáticos. 
Todos os litotipos apresentam enriquecimento em ETRL em relação aos ETRP, apresentando padrão de distribuição dos ETR fortemente fracionado em relação ao condrito (Fig. 64), como indicam os valores de $\mathrm{La} / \mathrm{Yb}_{\mathrm{N}}$ de 8,1 a 74,77.

As amostras de biotita gnaisse granodiorítico apresentam maior variação dos valores de $\Sigma_{\text {ETR }}\left(83\right.$ a 146), $\mathrm{La} / \mathrm{Yb}_{\mathrm{N}}\left(9,6\right.$ a 74,44) e de $\mathrm{Eu} / \mathrm{Eu}^{*}(0,86$ a 1,45$)$, que reflete sutis anomalias negativas de Eu em duas amostras e positiva em uma amostra (Fig. 61). A amostra de biotita gnaisse granítico apresenta menor conteúdo de $\Sigma_{\mathrm{ETR}}(52)$, forte fracionamento de ETRL $\left(\mathrm{La} / \mathrm{Yb}_{\mathrm{N}}=38,4\right)$ e ausência de anomalia de Európio $\left(\mathrm{Eu} / \mathrm{Eu}^{*}=0,86\right.$ a 1,45$)$. O gnaisse milonitizado apresenta maior conteúdo de ETR $\left(\Sigma_{\mathrm{ETR}}=154\right)$, porém assemelha-se aos demais gnaisses em relação os valores de $\mathrm{La} / \mathrm{Yb}_{\mathrm{N}}(33,9)$ e ausência de anomalia de Eu (Fig. 64).

A amostra de anfibólio-biotita granito foliado apresenta o maior valor de $\Sigma_{\text {ETR }}$ (251 ppm), os menores valores de $\mathrm{La} / \mathrm{Yb}_{\mathrm{N}}(8,1)$ e a anomalia negativa de Eu mais pronunciada $\left(\mathrm{Eu} / \mathrm{Eu}^{*}=0,6\right)$. O biotita leucogranito $\left(\Sigma_{\mathrm{ETR}}=75\right)$ não apresenta anomalias de európio $\left(\mathrm{Eu} / \mathrm{Eu}^{*}=1,0\right)$.

No diagrama multielementar normalizado em relação ao condritos de Sun et al. (1980; Fig. 65), nota-se que os biotita gnaisses graníticos e granodioríticos apresentam anomalia negativa de $\mathrm{Nb}, \mathrm{Sm}$ e Ti acentuadas. Uma amostra de biotita gnaisse granodiorítico também mostra anomalia negativa de $\mathrm{U}$ e Ta, enquanto o gnaisse milonitizado apresenta maiores conteúdos de Th e U. O conjunto de amostras não mostra anomalias significativas de Sr. O anfibólio-biotita granito foliado difere dos demais litotipos devido, principalmente, os maiores conteúdos de $\mathrm{Nd}, \mathrm{Zr}$, Gd e Y.

A comparação entre a composição dos biotita gnaisses e os TTG, com base em elementos traços, apresenta algumas semelhanças, como apresentado na figura 65 . Adicionalmente, os valores de $\mathrm{Yb}_{\mathrm{N}}$ vs. $(\mathrm{La} / \mathrm{Yb})_{\mathrm{N}}$ dos gnaisses distribui-se no intervalo esperado para TTG e rochas adakíticas com alto conteúdo de sílica, com exceção do hornblenda-biotita granito foliado, que diferencia-se de todos os demais granitoides da área (Fig. 66). 

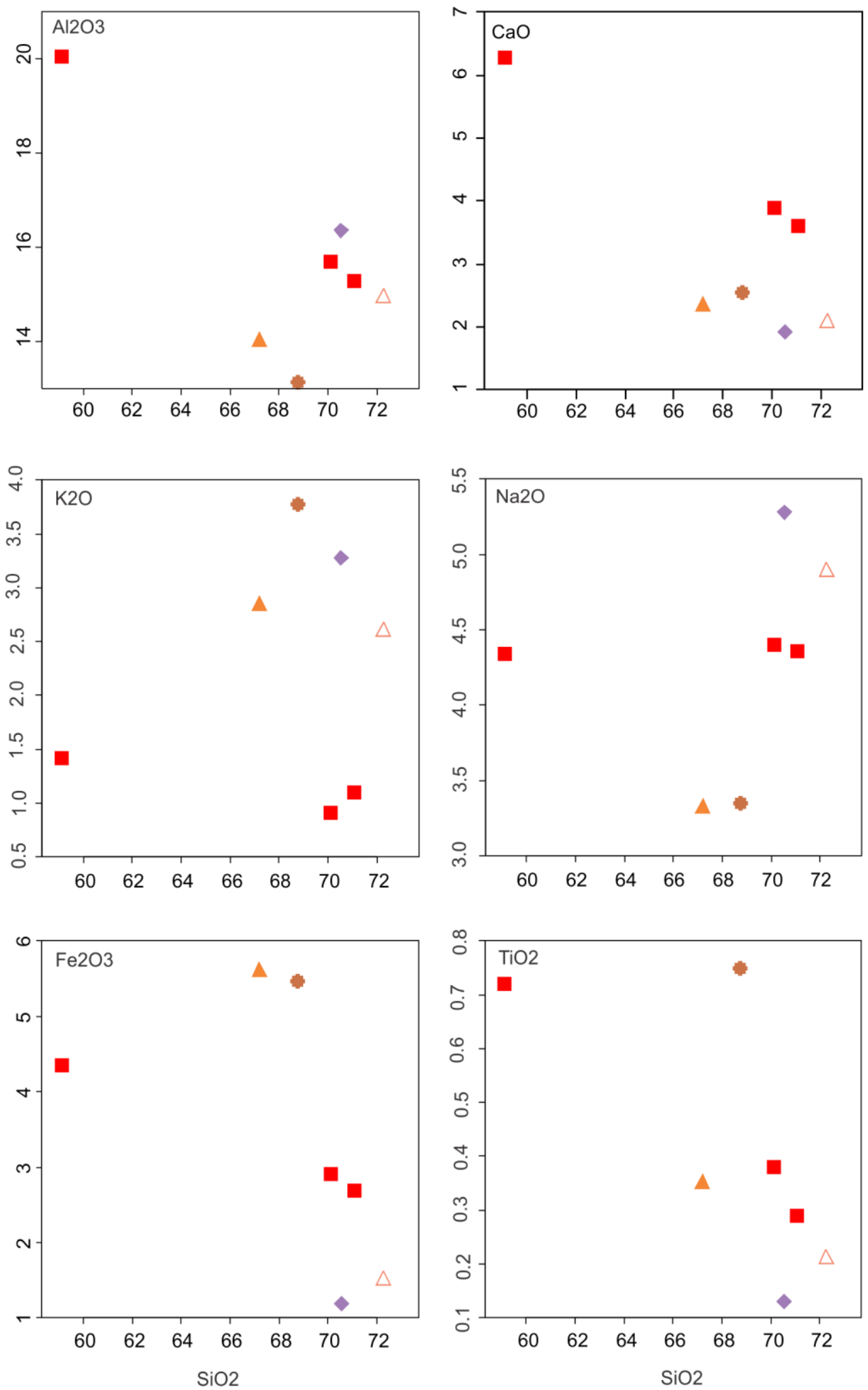

$\triangle$ Biotita leucogranito

- Anfibólio-biotita granito foliado

Biotita gnaisse granodiorítico $\Delta$ Gnaisse granodiorítico Biotita gnaisse granítico milonitizado

Figura 61: Diagramas de Harker mostrando as variações composicionais dos granitoides estudados. 

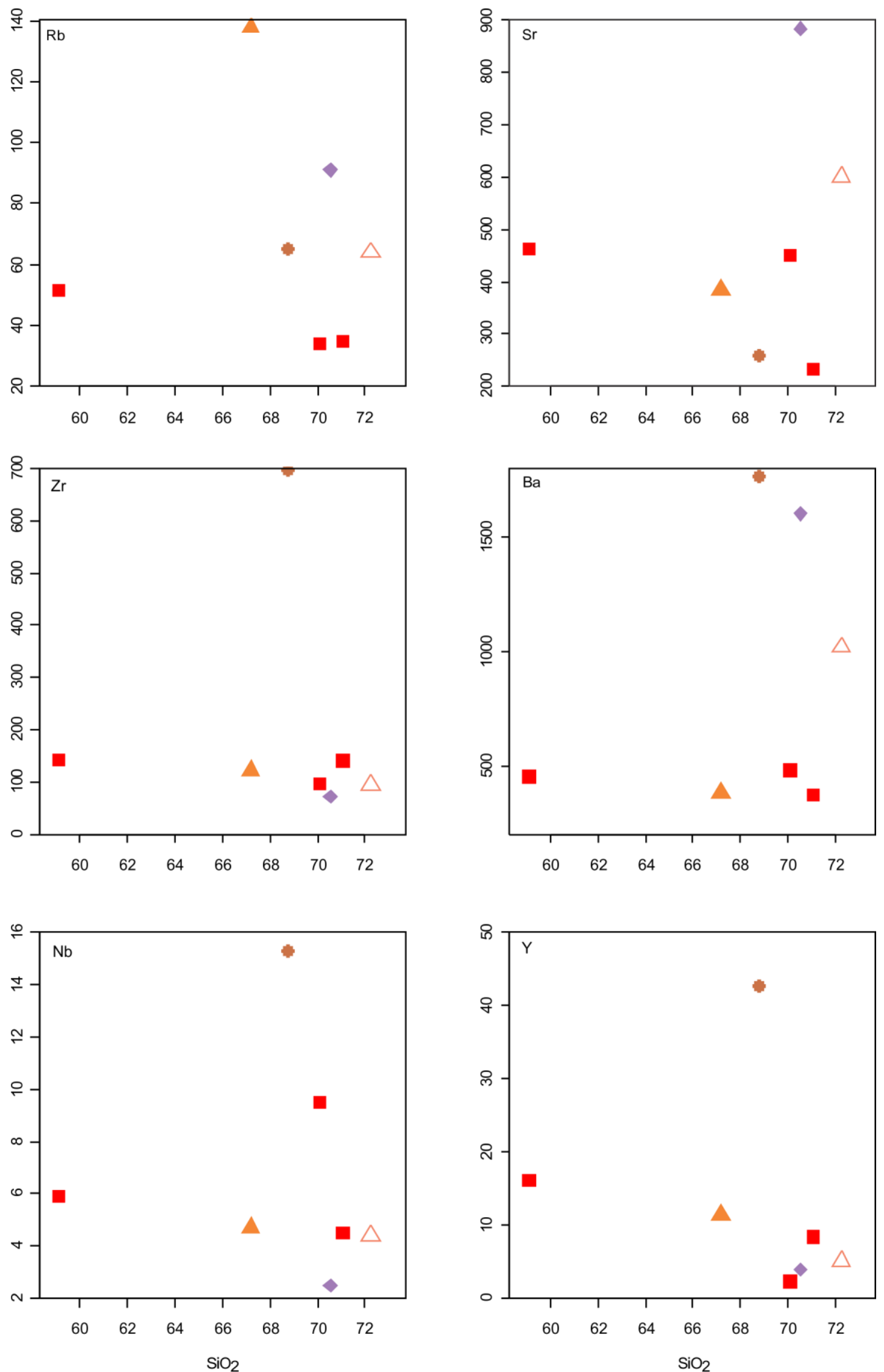

Biotita leucogranito Anfibólio-biotita granito foliado

Biotita gnaisse granodiorítico Biotita gnaisse granítico
Gnaisse granodiorítico milonitizado

Figura 62. Diagramas de Harker para elementos traços das rochas granitoides. 
A comparação entre a composição dos biotita gnaisses e os TTG, com base em elementos traços, apresenta algumas semelhanças, como apresentado na figura 65 . Adicionalmente, os valores de $\mathrm{Yb}_{\mathrm{N}}$ vs. $(\mathrm{La} / \mathrm{Yb})_{\mathrm{N}}$ dos gnaisses distribui-se no intervalo esperado para TTG e rochas adakíticas com alto conteúdo de sílica, com exceção do hornblenda-biotita granito foliado, que diferencia-se de todos os demais granitoides da área (Fig. 66).

De acordo com os critérios definidos por Moyen e Martin (2012), as características geológicas e litoquímicas dos biotita gnaisses granodioríticos e graníticos (trondhjemíticos) são semelhantes às dos TTG sódicos de médio ETRP, incluindo: (a) associação de ortognaisse polifásico com encraves e leucossoma; (b) conteúdo de $\mathrm{Na}_{2} \mathrm{O}$ entre 4 e $6 \%\left(\mathrm{Na}_{2} \mathrm{O}_{\mathrm{BG}}=4,34\right.$ a $5,28 \%$ ); (c) razão $\mathrm{K}_{2} \mathrm{O} / \mathrm{Na}_{2} \mathrm{O}$ entre 0,3 e $0,6\left(\mathrm{~K}_{2} \mathrm{O} / \mathrm{Na}_{2} \mathrm{O}_{\mathrm{BG}}=0,21\right.$ a 0,62$)$; (d) conteúdo de $\mathrm{Al}_{2} \mathrm{O}_{3}$ igual ou maior que $15 \%$ a $70 \%$ de $\mathrm{SiO}_{2}\left(\mathrm{Al}_{2} \mathrm{O}_{3 \mathrm{BG}}=15,29\right.$ a $16,36 \%$ a $\mathrm{SiO}_{2}$ de 70,11 a $71,07 \%$ ); (e) conteúdo de $\mathrm{Yb}$ menor que 1,5 pmm ( $\mathrm{Yb}_{\mathrm{ODG}}=0,20$ a 0,81 ppm); (f) valores de $(\mathrm{La} / \mathrm{Yb})_{\mathrm{N}}$ maiores que $15\left(\mathrm{La} / \mathrm{YbN}_{\mathrm{ODG}}=30,05\right.$ a 74,44); $(\mathrm{g})$ valores de $\mathrm{Sr} / \mathrm{Y}$ entre 20 e 200 $\left(\mathrm{Sr} / \mathrm{Y}_{\mathrm{BT}}=28\right.$ a 226,69); (h) anomalias negativas de $\mathrm{Nb}$-Ta e Ti; (i) ausência de anomalia significativa de Sr; (g) ausência de anomalia negativa de Eu, que no nos biotita gnaisses são pouco expressivas a positivas $\left(\mathrm{Eu} / \mathrm{Eu}^{*}=0,86\right.$ a 1,45$)$. Contudo, uma amostra de biotita gnaisse granodiorítico apresenta menor valor de $\mathrm{SiO}_{2}(59,12 \%)$ e maior $\mathrm{de}^{\mathrm{Al}_{2} \mathrm{O}_{3}}(20,06 \%)$, assim como razão $(\mathrm{La} / \mathrm{Yb})_{\mathrm{N}}$ de 9,6 e conteúdo de $\mathrm{Yb}$ de 1,61 ppm.

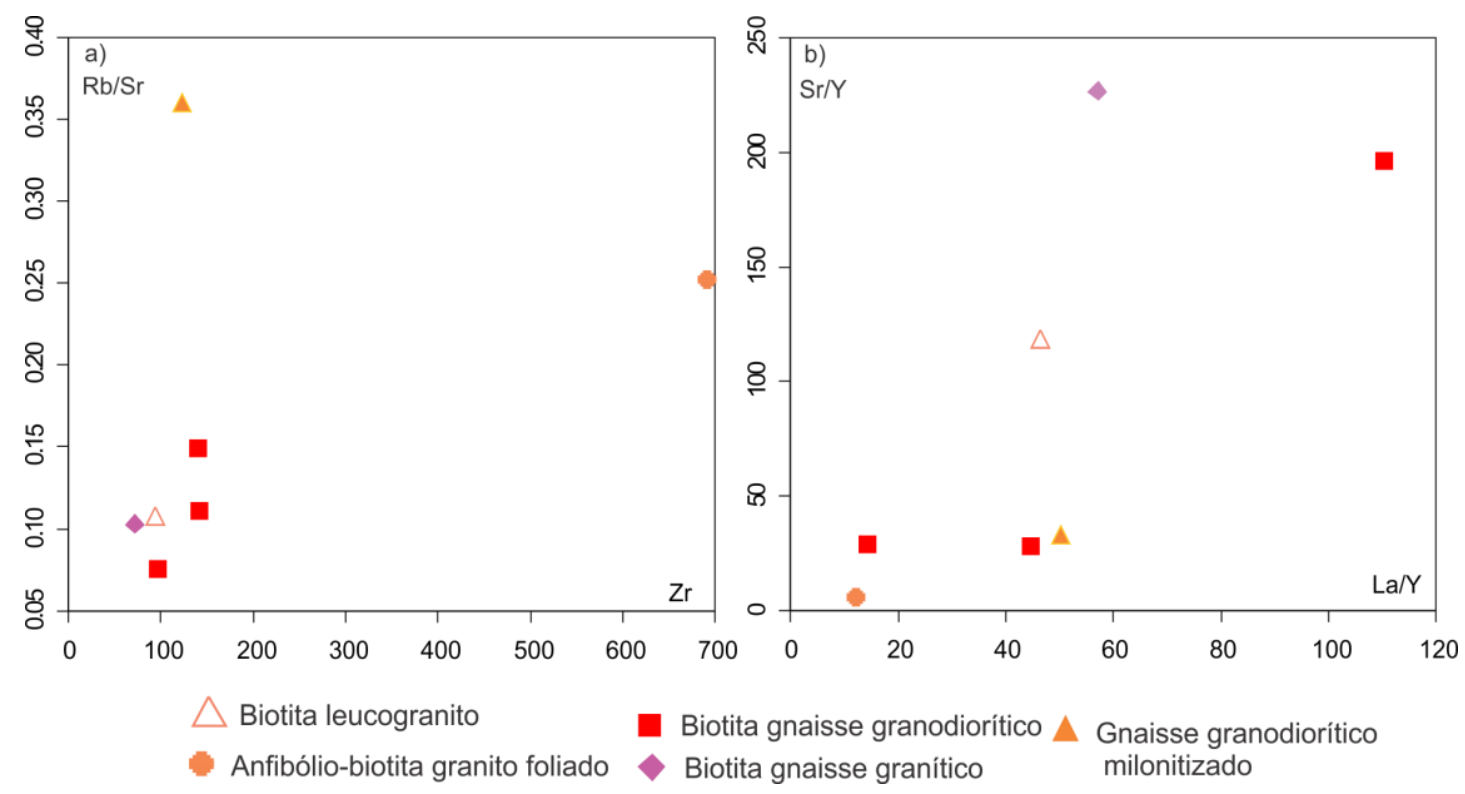

Figura 63: Diagramas dos elementos traços das unidades da área de Água Azul do Norte: (a) diagrama $\mathrm{Zr} v s$ $\mathrm{Rb} / \mathrm{Sr}$, (b) diagrama La/Yb vs $\mathrm{Sr} / \mathrm{Y}$. 


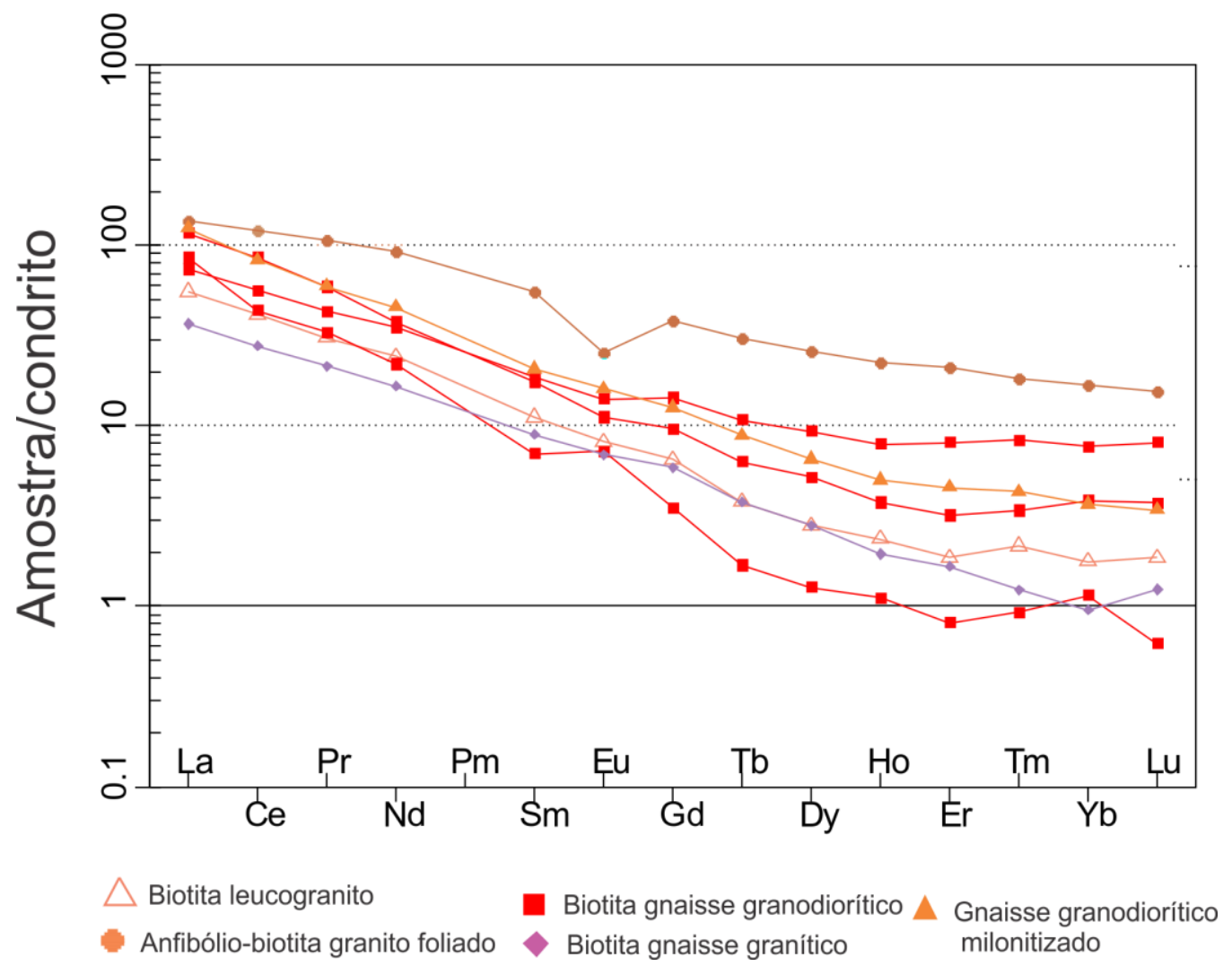

Figura 64: Padrões de ETR normalizado pelo condritos de Boyton (1984) para os gnaisses e rochas graníticas.

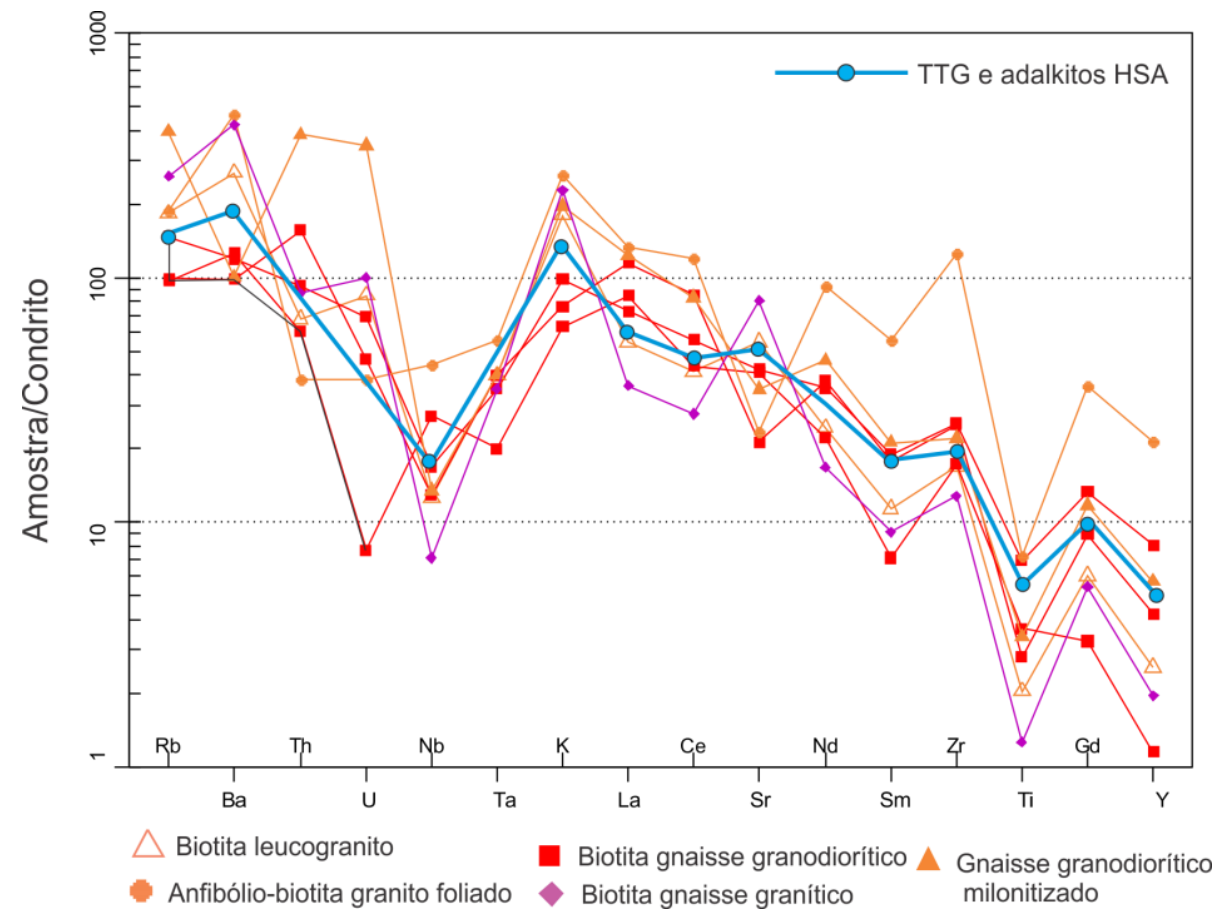

Figura 65. Diagrama multielementar normalizado em relação ao condritos de Sun et al. (1980), comparando as amostras de granitoides com a média da composição dos TTG e adakitos de alto conteúdo de sílica (HSA) de Martin et al. (2005). 


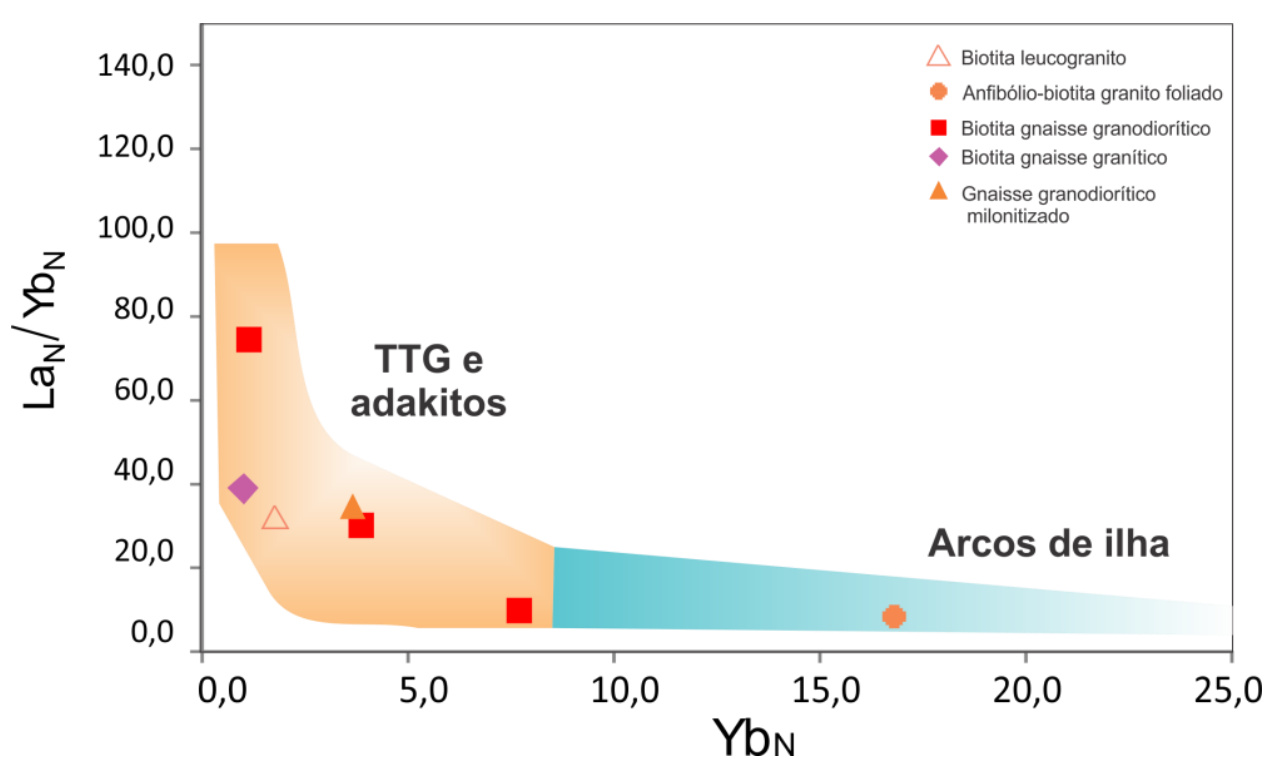

Figura 66. Diagrama de Martin et al. (1999) para a distinção entre TTG, adakitos e rochas de arcos de ilha, mostrando a semelhança dos biotita gnaisses com TTG.

\subsubsection{Ambiente tectônico}

De acordo com a classificação de ambiente tectônico de Pearce et al. (1984), todos os granitóides apresentam semelhanças com granitos de arcos vulcânicas (VAG). Entretanto, o hornblenda-biotita granito foliado também compartilha algumas características de granitos de ambiente intra-placa, especialmente devido aos seus conteúdos mais elevados de $\mathrm{Y}$ e $\mathrm{Y}+\mathrm{Nb}$ (Fig. 67).

A figura 68 apresenta a comparação dos gnaisses e granitos estudados com a média da crosta continental arqueana e com TTG arqueanos, que foram interpretados por Condie e Kröner (2013) como formados em arco continental. 

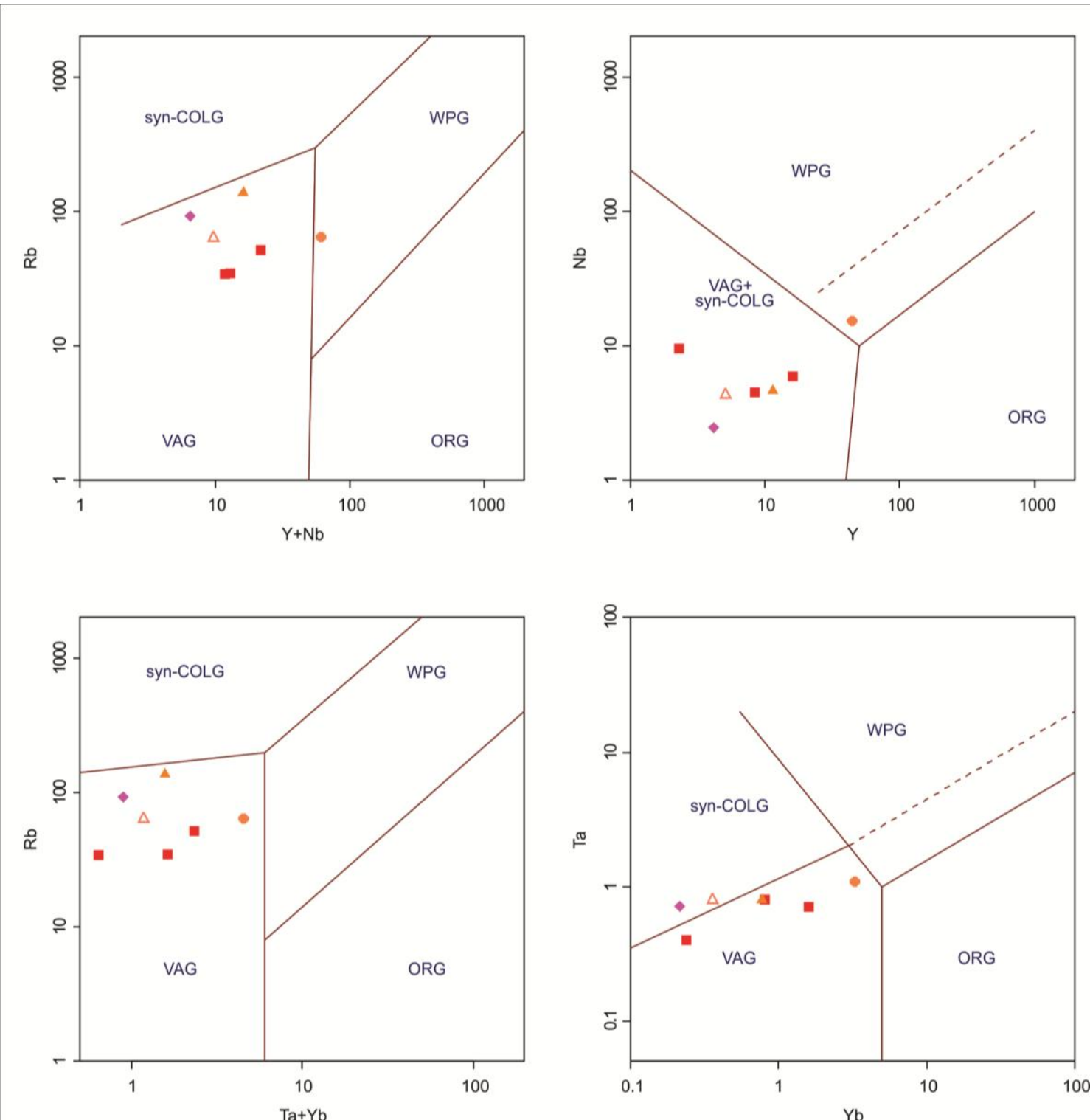

$\triangle$ Biotita leucogranito Anfibólio-biotita granito foliado

Biotita gnaisse granodioritico $\Delta$ Gnaisse granodiorítico Biotita gnaisse granítico milonitizado

Figura 67. Diagramas discriminantes de ambiente tectônico para rochas graníticas de Pearce et al. (1984). 


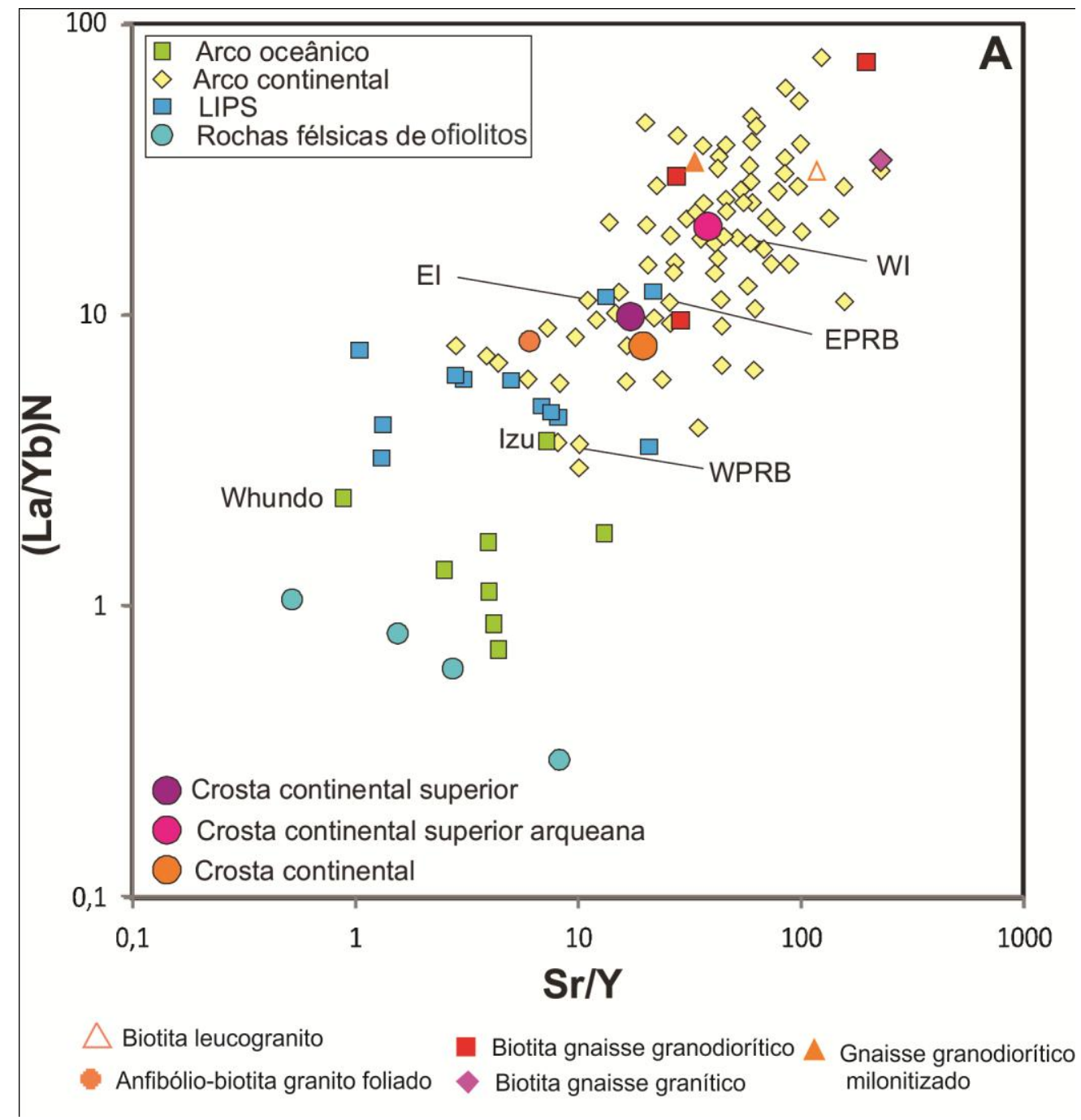

Figura 68. Diagrama de $\log (\mathrm{Sr} / \mathrm{Y})$ vs. $\log (\mathrm{La} / \mathrm{Yb})_{\mathrm{N}}$ proposto por Condie e Kröner (2013) para mostrar a distribuição de rochas ígneas félsicas, incluindo vulcânicas, hipoabissais e plutônicas, de diferentes ambientes tectônicos e a comparação entre amostras de gnaisses e granitos da região de Água Azul do norte, Província Carajás, com rochas de arco continental, oceânico, LIPS e rochas félsicas de sequências ofiolíticas. LIP = Large Igneous Province; WI e EI = composição média das rochas ígneas félsicas da Irlanda Ocidental e Oriental, respectivamente (Draut et al. 2002; 2009); EPRB e WPRB = Batólito de Peninsular Range, Califórnia (Lee $e t$ al., 2007); Izu = Arco Izu-Bonin, Complexo Granítico Izu (Saito et al. 2007); Whundo = Arco Whundu, Pilbara, Austrália (Smithies et al., 2005). Exceto para as amostras do Complexo Xingu, cada ponto no gráfico refere-se ao valor médio de cada localidade. Análises compliladas por Condie e Kröner (2013). Composições médias da crosta continental são de Rudnick \& Gao (2003). 


\section{DISCUSSÕES}

\subsection{O GREENSTONE BELT SAPUCAIA: CARACTERIZAÇÃO DOS LITOTIPOS}

O Grupo Sapucaia na área de Água Azul do Norte aflora próximo ao contato entre os domínios Rio Maria, ao sul, e Carajás, ao norte. Corresponde a uma faixa alongada e lenticularizada, com direção preferencial E-W, em contato tectônico com o Tonalito Caracol (2,92 a 2,94 Ga; Leite et al. 2004), ao sul, e gnaisses e migmatitos do Complexo Xingu, ao norte, que registra metamorfismo em ca. 2,86 Ga, referente ao segundo evento de migmatização reconhecido nessa unidade (Machado et al. 1991).

Os litotipos do Grupo Sapucaia caracterizados nesse estudo podem ser agrupados em três unidades: (i) unidade metaultramáfica (clorita-tremolita xistos, clorita-actinolita xistos, serpentinitos e clorititos); (ii) unidade máfica (Mg-hornblenda/hornblenda anfibolitos); e (iii) unidade metassedimentar (biotita-muscovita xisto com almandina). Essas unidades foram atribuídas em estudos prévios à uma sequência metavulcanossedimentar do tipo greenstone belt (Araújo \& Maia 1991), embora na área estudada não tenham sido reconhecidos alguns litotipos, tais como formações ferríferas do tipo Algoma, chert, metaexalitos, ou estruturas do tipo pillow lavas nos basaltos e komatiítos, característicos dessas sequências. A ampla predominância de rochas metaultramáficas na área de Água Azul do Norte sugere que principalmente as partes basais da sequência greenstone belt sejam aflorantes, ou tenham sido preservadas, nessa região.

A unidade metaultramáfica inclui litotipos nos quais relíquias de estruturas ígneas foram apenas raramente reconhecidas. Os estudos petrográficos permitiram a caracterização de (antofilita)-clorita-tremolita xistos (tremolita $+\mathrm{Mg}$-clorita + magnetita \pm antofilita \pm talco \pm carbonato \pm ilmenita \pm pirrotita), edenita-clorita xisto (clorita + edenita/fluoroedenita \pm antofilita \pm magnetita \pm serpentina \pm talco) e clorita-actinolita xistos (actinolita + clorita \pm magnetita \pm talco) predominantes.

A paragênese típica dos (antofilita)-clorita-tremolita xistos é análoga à descrita como resultante do metamorfismo de protólitos komatííticos (Jolly 1982; Gole et al. 1987). Essa paragênese evidencia progressão do metamorfismo pós Sn-1 e durante o desenvolvimento da Sn em condições de fácies anfibolito, como indicado pela substituição da tremolita por antofilita ou, alternativamente, formação de antofilita a partir de tremolita e magnesita ainda em condições de fácies xisto verde superior (Ford \& Skippen 1997).

Os clorita-tremolita xistos e clorita-actinolita xistos apresentem semelhanças químicas com rochas komatíticas. Entretanto, a definição de komatiíto de Arndt et al. (2008) estabelece que "komatiíto é uma rocha vulcânica ultramáfica com textura spinifex ou relacionada a derrames de lavas contendo essa textura". Embora textura spinifex não tenha sido caracterizada nesse estudo, estudos prévios como os de Araújo \& Maia (1991) descreveram textura spinifex em rochas metaultramáficas com afinidade komatiítica nas proximidades do Igarapé Sapucaia, confirmando a presença desses litotipos no Grupo Sapucaia. Ainda assim, a ausência de texturas preservadas nos litotipos estudados ou a associação clara desse litotipos com outros do Greenstone Belt Sapucaia nos quais a textura spinifex já foi descrita, dificulta sua classificação definitiva.

Adicionalmente, cummingtonita-clorita-tremolita xisto (cummingtonita/ $\mathrm{Mg}$ -

cummingtonita + clorita \pm tremolita \pm magnetita \pm talco \pm serpentina \pm talco \pm magnetita) ocorre associado a esses litotipos e representa marcantes diferenças geoquímicas em relação Dissertação de Mestrado - IG-USP - Soraya Damasceno Sousa - 2014 
às demais rochas metaultramáficas, tais como elevados conteúdos de $\mathrm{MgO}$ e \#Mg. De acordo com Arndt et al. (2008), líquidos komatíticos apresentam um limite máximo de $30 \%$ de $\mathrm{MgO}$ e rochas com conteúdos superiores de $\mathrm{MgO}$, semelhantes a duas das amostras de antofilitaMg-cummingtonita xistos, podem representar rochas cumuláticas (olivine cumulates), que comumente associam-se aos derrames.

Corpos de serpentinitos (lizardita + nimita + magnetita \pm calcedônia com relíquias de olivina) foram reconhecidos nos mesmos afloramentos nos quais os clorita-tremolita xistos são predominantes. A presença de lizardita, identificada por difração de raios X, pode refletir as condições predominantes durante o retrometamorfismo em condições de fácies xisto verde inferior, nas quais a antigorita é instável (Evans 2004). Tais rochas foram também interpretadas como formadas a partir de protólitos cumuláticos ricos em olivina que podem representar os condutos a partir dos quais as lavas extravasaram (Lesher et al. 1984, 1989; Hill et al. 1995).

Próximo ao contato com gnaisses e migmatitos do Complexo Xingu, os cloritatremolita xistos apresentam gradações para clorita-actinolita xistos, talco xistos (talco + clinocloro + magnetita) e cloritito (clorita + magnetita + cromomagnetita \pm antofilita \pm apatita \pm zircão \pm ilmenita \pm rutilo \pm monazita \pm serpentina \pm dolomita \pm quartzo \pm biotita). Esses litotipos são semelhantes aos produtos de processos metassomáticos sin-metamórficos resultantes do gradiente de potencial químico entre as rochas metaultramáficas e os gnaisses, caracterizando zonas com alteração blackwall (Winter 2010, Bucher \& Grape 2011).

Cálculos de balanço de massa indicaram que os clorita-actinolita xistos resultaram de perda de massa de aproximadamente $12 \%$, com perdas de $\mathrm{SiO}_{2}, \mathrm{CaO}, \mathrm{Na}_{2} \mathrm{O}, \mathrm{Co}, \mathrm{V}, \mathrm{Ga}, \mathrm{Cu}$, $\mathrm{Sr}, \mathrm{Rb}, \mathrm{Zr}, \mathrm{Nb}$, Ba e Ce e ganhos relativos de $\mathrm{Ni}, \mathrm{Y}, \mathrm{Zn}$ e La. Nos clorititos essas mudanças foram muito intensas, refletindo expressiva perda de massa (78\%), com perdas relativas de $\mathrm{SiO}_{2}, \mathrm{MgO}, \mathrm{MnO}, \mathrm{CaO}$, além de $\mathrm{Ni}, \mathrm{Cu}, \mathrm{Co}$ e $\mathrm{V}$. Os ganhos refletem claramente a lixiviação pelos fluidos hidrotermais de $\mathrm{P}_{2} \mathrm{O}_{5}, \mathrm{Zr}$, Th, U e ETRL dos granitoides e incorporação desses nos clorititos. Assim, os clorita-actinolita xistos podem representar zonas mais distais de alteração, nas quais características dos protólitos ainda foram parcialmente preservadas, enquanto os clorititos são proximais e resultaram de intenso metassomatismo. A lixiviação de metais em rochas metaultramáficas, em especial do $\mathrm{Cu}$, pode ter importante implicação metalogenética, uma vez que depósitos cupríferos hidrotermais são notáveis na Província Carajás, por exemplo, Sossego, Salobo, Alvo 118, Cristalino, Igarapé Bahia (Hunh \& Nascimento 1997, Lindenmayer et al. 1999; Réquia et al. 2003; Tallarico et al. 2005; Monteiro et al. 2008; Xavier et al. 2012) . Assim, o cobre pode ter sido lixiviado por fluidos hidrotermais, ao menos em parte, a partir de mecanismos de interação fluido-rocha envolvendo grandes volumes de rochas em sistemas hidrotermais regionais.

Adicionalmente, entre os litotipos metaultramáficos foi caracterizado apenas localmente olivina-hercinita-clorita- $(\mathrm{Mg})$ hornblenda xisto (Mg-hornblenda/Mg-ferrihornblenda + Mg-clorita + forsterita + hercinita + cromomagnetita \pm magnetita \pm serpentina). Esse litotipo apresenta deformação dúctil de alta temperatura revelada pelo forte estiramento da olivina, semelhante à característica de corpos de peridotitos do manto superior.

A unidade metabásica é caracterizada por hornblenda e magnesiohornblenda anfibolitos, cujos protólitos são classificados como basaltos, de acordo com Le Maitre (1989). Esses litotipos apresentam tendência tholeiítica e não mostram fracionamento de elementos terras raras leves em relação aos pesados $\left(\mathrm{La} / \mathrm{Yb}_{\mathrm{N}}=1,00\right)$, exceto em uma amostra. As suas 
razões de elementos HFS ( $\mathrm{La}, \mathrm{Sm}, \mathrm{Yb}, \mathrm{Nb}$ e Th) indicam nos diagramas para discriminação de ambiente geotectônico de rochas ultrabásicas e básicas, proposto por Agrawal et al. (2008), formação em ambiente MORB. Entretanto, a ocorrência de metabasitos na área é pouco comum e poucas amostras de metabasitos foram analisadas nesse estudo. Adicionalmente, as amostras analisadas revelam considerável metassomatismo, que se reflete na grande dispersão dessas amostras em grande parte dos diagramas.

Os metabasitos foram submetidos a condições de metamorfismo em fácies anfibolito inferior durante o desenvolvimento da foliação $\mathrm{Sn}$, como indica a presença de titanita, que comumente é consumida em fácies anfibolito superior (Spear et al. 1993). Tais condições são condizentes com a paragênese observada nos biotita-muscovita xistos com granada, que representam os metapelitos presentes na área.

Dessa forma, os litotipos metaultramáficos, metabásicos e metapelitos registram condições de metamorfismo análogas, com pico na fácies anfibolito inferior, enquanto os $\mathrm{Mg}$ hornblenda-Mg-clorita-olivina-hercinita xistos apresentam paragênese compatível com condições P-T prevalecentes na fácies anfibolito superior transicional para fácies granulito, diferindo, portanto, daquelas registradas nos demais litotipos metaultramáficos do Greenstone Belt Sapucaia.

\subsection{NATUREZA DO MAGMATISMO ULTRAMÁFICO}

A avaliação das características químicas dos litotipos metaultramáficos requer avaliação cuidadosa da mobilidade dos elementos químicos em decorrência de processos metassomáticos. Os estudos geoquímicos de Arndt (1994), Condie (1994) e Brewer \& Menuge (1996) em rochas vulcânicas máficas e ultramáficas pré-cambrianas sugeriram que os elementos HFS (High field strength, tais como Nb, Ta, Zr, Hf, Ti), assim como Y, V, Al, Ti e Sc são menos susceptíveis a alteração durante o metamorfismo de fácies xisto verde e podem ser úteis na caracterização da composição da fonte magmática dessas rochas. Entretanto, no conjunto de amostras metaultramáficas analisado nesse estudo, mobilidade relativa de ETR e Y foi verificada em amostras com evidências de metassomatismo, especialmente nos cloritaactinolita xistos e cloritito.

As rochas metaultramáficas menos metassomatisadas (antofilita-clorita-tremolita xistos) apresentam conteúdo de $\mathrm{MgO}$ entre $19,29 \%$ e 22,55\% e de $\mathrm{TiO}_{2}$ de 0,36\% a 0,53\%, sendo classificadas como komatiítos e, subordinadamente, basaltos komatíticos. Apesar de não apresentarem a textura spinifex típica que caracteriza os komatiítos, essas rochas possuem semelhanças geoquímicas com komatiítos do tipo Barberton, tais como, razões $\mathrm{CaO} / \mathrm{Al}_{2} \mathrm{O}_{3}>1$ (1,06 a 1,63), de $\mathrm{Al}_{2} \mathrm{O}_{3} / \mathrm{TiO}_{2}$ menores que 20 (entre 10,18 e 18,32) e de $(\mathrm{Gd} / \mathrm{Yb})_{\mathrm{N}}$ entre 1,31 e 3,46. Entretanto, os valores de $(\mathrm{Gd} / \mathrm{Yb})_{\mathrm{N}}$ de 1,31 a 3,46 são ainda mais elevados que os reportados para komatíitos desse tipo, além de evidenciarem maior dispersão.

Enriquecimentos em ETRL em relação aos ETRP $\left[(\mathrm{La} / \mathrm{Yb})_{\mathrm{N}}=3,01-26\right]$, anomalias de Eu levemente negativas a ausentes $\left(\mathrm{Eu} / \mathrm{Eu}^{*}=0,77\right.$ a 0,99$)$ e pronunciadas anomalias 
negativas de $\mathrm{Ce}\left(\mathrm{Ce} / \mathrm{Ce} e^{*}=0,04\right.$ a 0,86$)$ foram também verificadas nessas rochas metaultramáficas. Nos diagramas multielementares normalizados pelo manto primitivo, esses litotipos revelam anomalias positivas de $\mathrm{Nb}$ e negativas de $\mathrm{K}$, $\mathrm{Ti}, \mathrm{Sr}$ e $\mathrm{Zr}$.

As anomalias negativas de Ce podem ser atribuídas à remoção de Ce por fluidos relativamente oxidantes associados a metamorfismo de fundo oceânico ou regional (Kerrich et al. 2013). Entretanto, as razões $\mathrm{Zr} / \mathrm{Th}$ elevadas (93 a 122) dos (antofilita)-clorita-tremolita xistos, semelhantes às mantélicas, não são condizentes com significativa contaminação crustal relacionada aos processos pós-magmáticos. Adicionalmente, tanto as amostras de (antofilita)clorita-tremolita xistos do grupo $1 \mathrm{a}(\mathrm{Nb} / \mathrm{Th}=44$ a 96$)$ como do grupo $1 \mathrm{~b}(\mathrm{Nb} / \mathrm{Th}=16$ a 24$)$ apresentam valores elevados da razão $\mathrm{Nb} / \mathrm{Th}$, o que também não evidencia componentes crustais significativos. Por sua vez, as amostras de cloritito $(\mathrm{Nb} / \mathrm{Th}=0,94)$, antofilita- $\mathrm{Mg}$ cummingtonita xistos $(\mathrm{Nb} / \mathrm{Th}=0,50$ a 10) e clorita-actinolita xistos $(\mathrm{Nb} / \mathrm{Th}=1,50$ a 16$)$ revelam forte contribuição de componente crustal, possivelmente associado ao metassomatismo.

Assim, características geoquímicas dos (antofilita)-clorita-tremolita xistos podem fornecer informações a respeito da natureza do magma a partir do qual seus protólitos foram formados. Suas razões $\left(\mathrm{La} / \mathrm{Sm}_{\mathrm{N}}\right)$ e $\left(\mathrm{La} / \mathrm{Yb}_{\mathrm{N}}\right)$ possivelmente indicam fonte enriquecida em elementos incompatíveis (ETRL), análoga à de magmas resultantes de elevadas taxas de fusão do manto peridotítico com granada no resíduo. As anomalias negativas de $\mathrm{Zr}$ desses litotipos também seriam indicativas de segregação de magma em presença de majorita residual a profundidades maiores que $400 \mathrm{~km}$ (Polat et al. 1999).

Adicionalmente, as anomalias positivas de $\mathrm{Nb}$ evidenciam derivação de plumas mantélicas com contribuição de material do slab reciclado em grandes profundidades (Jayananda et al. 2013). Por sua vez, as razões entre elementos HFS, tais como $\mathrm{Nb} / \mathrm{Th}, \mathrm{Zr} / \mathrm{Nb}$, $\mathrm{Zr} / \mathrm{Y}$ e Nb/Y, indicam semelhança das rochas metaultramáficas com basaltos de ilha oceânica (OIB) transicionais para MORB, enquanto os metabasitos representariam tholeiítos formados em ambiente MORB.

O conjunto de características geoquímicas dos (antofilita)-clorita-tremolita xistos assemelham-se aos reportados por Polat et al. (1999) para os komatiítos empobrecidos em alumínio do tipo Barbenton do greenstone belt da Subprovíncia Wawa, Ontario, Canadá, com idade de 2,75 Ga. Tais rochas mostram, assim como os litotipos do Grupo Sapucaia, assinatura pouco comum devido ao enriquecimento em elementos incompatíveis $\left(\mathrm{La} / \mathrm{Sm}_{\mathrm{N}}=\right.$ $\left.1,1-2,3, \mathrm{Gd} / \mathrm{Yb}_{\mathrm{N}}=2,2-2,9\right)$, anomalias negativas de $\mathrm{Zr}$ e positivas de $\mathrm{Nb}$. Essas características foram interpretadas como derivadas de uma pluma mantélica heterogênea, incluindo fontes mantélicas com características do manto empobrecido e de crosta oceânica subductada e Dissertação de Mestrado - IG-USP - Soraya Damasceno Sousa - 2014 
reciclada no manto profundo.

Embora os antofilita-Mg-cummingtonita xistos apresentem evidências de processos metassomáticos, sua assinatura geoquímica caracterizada por conteúdo mais elevado de $\mathrm{MgO}$ (25,50 a 35,77\%) e menor de $\mathrm{CaO}(0,01$ a $4,10 \%), \mathrm{TiO}_{2}(0,02$ a $0,18 \%)$ e $\mathrm{Al}_{2} \mathrm{O}_{3}(0,56 \%$ a 8,21\%), associado aos conteúdos muito baixos de ETR (1 a 10 ppm) e Y (0,40 a 8,20\%), razões $(\mathrm{Gd} / \mathrm{Yb})_{\mathrm{N}}$ mais baixas $(0,48$ a 0,88$)$ e às anomalias negativas de $\mathrm{Nb}$, não podem ser atribuídos apenas a processos pós-magmáticos. Assim, a diversidade de características químicas dos litotipos metaultramáficos do Grupo Sapucaia pode refletir a natureza também heterogênea dos magmas que originaram seus protólitos. Heterogeneidade química em komatiítos e litotipos associados também foi descrita no Greenstone Belt Abitibi (ca. 2,7 Ga; Fan \& Kerrich 1997) e nos greenstone belts Schreiber-Hemlo e White River-Dayohessarah na Subprovíncia Wawa, Canadá (Polat et al. 1999). Nesses casos, essas assinaturas químicas foram associados à formação de platôs oceânicos a partir de pluma heterogênea com múltiplos componentes. Um cenário análogo pode ser sugerido para o Greenstone Belt Sapucaia, embora estudos adicionais sejam necessários para a caracterização das fontes mantélicas.

\subsection{COMPARAÇÕES DO GRUPO SAPUCAIA COM OS DEMAIS GREENSTONE BELTS DA PROVÍNCIA CARAJÁS}

São reportados na literatura estudos petrográficos, geoquímicos e isotópicos relativos aos greenstone belts do Domínio Rio Maria, na parte sul da Província Carajás, especialmente sobre o Greenstone Belt Identidade (e.g. Souza \& Dall'Agnol 1996, Souza et al. 1997, 2001).

Segundo Souza \& Dall'Agnol (1996), o Greenstone Belt Identidade é composto por rochas metaultramáficas xistosas, contendo quantidades variadas de anfibólio incolor, talco e clorita, unidade metabásica, representada por metabasaltos e metagabros, e unidade dacítica. De forma análoga ao observado no Grupo Sapucaia, os litotipos do Greenstone Belt Identidade não apresentam mineralogia primária preservada, porém, Souza \& Dall1Agnol (1996) descreveram nessas rochas arranjo entre os cristais de anfibólio e a matriz com talco e clorita interpretados como relíquias de texturas spinifex paralelas, triangulares e espinha de peixe.

As rochas metaultramáficas do Greenstone Belt Identidade apresentam, segundo Souza et al. (1997), conteúdos médios de $\mathrm{SiO}_{2}$ (46,56\%), $\mathrm{MgO}(25,58 \%), \mathrm{Al}_{2} \mathrm{O}_{3}$ (7,77\%), $\mathrm{Fe}_{2} \mathrm{O}_{3}(11,1 \%), \mathrm{CaO}(5,45 \%)$ e $\mathrm{TiO}(0,23 \%)$, semelhantes aos das rochas metaultramáficas menos metassomatisadas do Greenstone Belt Sapucaia. As rochas metaultramáficas do Greenstone Belt Sapucaia são semelhantes aos komatiitos empobrecidos em alumínio do tipo Barbeton, enquanto os litotipos do Greenstone Belt Identidade não são empobrecidos em $\mathrm{Al}_{2} \mathrm{O}_{3}$, embora apresentem enriquecimento em ETRL $\left(\mathrm{La}_{\mathrm{N}} / \mathrm{Sm}_{\mathrm{N}}=2.22\right)$ e ETRP $\left(\mathrm{Gd}_{\mathrm{N}} / \mathrm{Yb}_{\mathrm{N}}\right.$ Dissertação de Mestrado - IG-USP - Soraya Damasceno Sousa - 2014 
$\left.=1.23 ; \mathrm{La}_{\mathrm{N}} / \mathrm{Yb}_{\mathrm{N}}=4.79\right)$ e razões de $\mathrm{CaO} / \mathrm{Al}_{2} \mathrm{O}_{3}=0.80$ e de $\mathrm{Al}_{2} \mathrm{O}_{3} / \mathrm{TiO}_{2}=20$.

Souza et al. $(1997,2001)$ sugerem origem do magma parental dessas rochas a partir de altas taxas de fusão parcial do manto peridotítico com pequenas quantidades de granada ligeiramente empobrecido em elementos incompatíveis como fonte do magmatismo ultramáfico dessas rochas. Adicionalmente, nos possíveis metakomatiítos do Greenstone Belt Sapucaia, as elevadas razões $\mathrm{Gd} / \mathrm{YbN}(0,72$ - 2,5) indicam a formação de seus protólitos a partir de magmas resultantes de fusão do manto peridotítico com granada no resíduo, possivelmente em maiores profundidades.

Adicionalmente, as rochas metaultramáficas do Greenstone Belt Sapucaia não mostram anomalias positivas de $\mathrm{Nb}$, e seu ambiente tectônico de formação foi interpretado como análogo ao de arcos de ilhas intraoceânicos (Souza et al., 2001). Dessa forma, significativa diversidade química e possivelmente tectônica resultou no magmatismo ultramáfico do Domínio Rio Maria.

\subsection{GRANITOIDES DA ÁREA DE ÁGUA AZUL DO NORTE}

Os granitoides reconhecidos na área de Agua Azul do Norte incluem um conjunto de gnaisses, por vezes migmatizados elou milonitizados, além de biotita leucogranito e hornblenda-biotita granito foliado. Os protólitos dos biotita gnaisses apresentam composição tonalítica a granodiorítica ou trondjemítica e representam rochas magnesianas, peraluminosas e cálcicas a cálcico-alcalinas, de acordo com os critérios de Frost at al. (2001). O biotita leucogranito apresenta composição trondjemítica e mostra semelhanças químicas com os gnaisses. Por sua vez, o anfibólio-biotita granito apresenta composição granítica a quartzomonzonítica e é distinto dos demais, por ser ferroso, metaluminoso e alcalino, e apresentar conteúdos mais elevados de $\mathrm{Zr}, \mathrm{Nb}, \mathrm{Ba}, \mathrm{Y}$ e ETR.

Os biotita gnaisses apresentam fracionamento variável, mas significativo, dos elementos terras raras leves em relação aos pesados $\left(\mathrm{La} / \mathrm{Yb}_{\mathrm{N}}=9,6\right.$ a 74,44) e anomalias de európio negativas sutis a ausentes ou positivas $\left(\mathrm{Eu} / \mathrm{Eu}^{*}=0,86\right.$ a 1,45$)$, enquanto o anfibólio-biotita granito foliado apresenta menores valores de $\mathrm{La} / \mathrm{Yb}_{\mathrm{N}}(8,1)$ e a anomalia negativa de Eu mais pronunciada $\left(\mathrm{Eu} / \mathrm{Eu}^{*}=0,6\right)$. Os gnaisses milonitizados apresentam maiores conteúdos de Th e U, que podem refletir metassomatismo ao longo das zonas de cisalhamento.

De acordo com os critérios definidos por Moyen e Martin (2012), as características geológicas e litoquímicas dos biotita gnaisses tonalíticos, granodioríticos e graníticos (trondhjemíticos) são semelhantes às dos TTG sódicos de médio ETRP, incluindo: (a) associação de ortognaisse polifásico com encraves e leucossoma; (b) conteúdo de $\mathrm{Na}_{2} \mathrm{O}$ entre 4 e $6 \%\left(\mathrm{Na}_{2} \mathrm{O}_{\mathrm{BG}}=4,34\right.$ a 5,28\%); (c) razão $\mathrm{K}_{2} \mathrm{O} / \mathrm{Na}_{2} \mathrm{O}$ entre 0,3 e $0,6\left(\mathrm{~K}_{2} \mathrm{O} / \mathrm{Na}_{2} \mathrm{O}_{\mathrm{BG}}=0,21\right.$ a 
0,62); (d) conteúdo de $\mathrm{Al}_{2} \mathrm{O}_{3}$ igual ou maior que $15 \%$ a $70 \%$ de $\mathrm{SiO}_{2}\left(\mathrm{Al}_{2} \mathrm{O}_{3 \mathrm{BG}}=15,29\right.$ a $16,36 \%$ a $\mathrm{SiO}_{2}$ de 70,11 a 71,07\%); (e) conteúdo de $\mathrm{Yb}$ menor que 1,5 pmm (YboDG $=0,20$ a 0,81 ppm); (f) valores de $(\mathrm{La} / \mathrm{Yb})_{\mathrm{N}}$ maiores que $15\left(\mathrm{La} / \mathrm{YbN}_{\mathrm{ODG}}=30,05\right.$ a 74,44); (g) valores de $\mathrm{Sr} / \mathrm{Y}$ entre 20 e $200\left(\mathrm{Sr} / \mathrm{Y}_{\mathrm{BT}}=28\right.$ a 226,69); (h) anomalias negativas de $\mathrm{Nb}$-Ta e Ti; (i) ausência de anomalia significativa de Sr; (g) ausência de anomalia negativa de Eu, que nos biotita gnaisses são pouco expressivas a positivas $\left(\mathrm{Eu} / \mathrm{Eu}^{*}=0,86\right.$ a 1,45$)$. Contudo, uma amostra de biotita gnaisse granodiorítico apresenta menor valor de $\mathrm{SiO}_{2}(59,12 \%)$ e maior de $\mathrm{Al}_{2} \mathrm{O}_{3}(20,06 \%)$, assim como razão $(\mathrm{La} / \mathrm{Yb})_{\mathrm{N}}$ de 9,6 e conteúdo de $\mathrm{Yb}$ de 1,61 ppm.

Os biotita gnaisses representariam, portanto, suítes TTG com assinatura química similar a de granitos de arcos vulcânicos (VAG) e da média da crosta continental arqueana (Condie e Kröner 2013). As elevadas razões $\mathrm{Nb} / \mathrm{Yb}, \mathrm{Sr} / \mathrm{Y}$ e $(\mathrm{La} / \mathrm{Yb})_{\mathrm{N}}$ dos biotita gnaisses refletem possivelmente evolução a partir da fusão de metabasaltos hidratados a pressões elevadas (acima de 12 kbar), compatíveis com estabilidade da granada e anfibólio no resíduo. Segundo Condie \& Kröner (2013), essa assinatura química seria mais comum em rochas geradas em ambientes de arcos magmáticos continentais e resultaria da geração do magma parental por fusão da crosta oceânica subductada durante o Arqueano, de modo análogo ao proposto por Martin (1986) e Martin et al. (2010) no modelo de "Hot Subduction".

Os ortognaisses TTG podem ser atribuídos ao Complexo Xingu (Silva et al.1974; DOCEGEO 1988), no qual foram inicialmente reconhecidos gnaisses, migmatitos, granulitos e granitoides diversos. Estudos recentes permitiram a caracterização mais refinada dos litotipos atribuídos ao embasamento da província, sobretudo no Domínio Rio Maria, permitindo a individualização de novas unidades geológicas (e.g. Almeida et al. 2010, 2001). Com isso a ocorrência do Complexo Xingu, que inclui litotipos gnáissicos, ficou restrita apenas ao Domínio Carajás.

Por sua vez, o hornblenda-biotita granito foliado compartilha algumas características com os granitos do tipo A de ambiente intra-placa. Suas características são semelhantes aos dos granitos alcalinos da Suíte Planalto, de idade 2,72 a 2,73 (Feio et al. 2013) - que são metaluminosos, ferrosos, enriquecidos em $\mathrm{Zr}$, media razão $\mathrm{Rb} / \mathrm{Sr}$, e baixa razão $\mathrm{Sr} / \mathrm{Y}$ e $\mathrm{La} / \mathrm{Yb}$ - que representa extenso magmatismo neoarqueano reconhecido apenas no Domínio Carajás.

O debate sobre a evolução crustal no Arqueano é intenso e posições antagônicas são defendidas para explicar a formação dos terrenos granito-greenstone belt, incluindo o papel do diapirismo granítico (Hamilton 2011) ou processos análogos ao da tectônica de placas modernos (Condie \& Kröner 2013, Polat 2014). Embora uma avaliação aprofundada desses processos esteja muito além do escopo desse estudo, o conjunto de dados apresentados seria condizente com a evolução da sequência de greenstone belt em platôs oceânicos com Dissertação de Mestrado - IG-USP - Soraya Damasceno Sousa - 2014 
influência de plumas mantélicas com múltiplos componentes, acrescionados em margens convergentes ao proto-continente, representado pelos TTGs do Complexo Xingu, formados em ambiente de arco magmático e intrudidos pelo Tonalito Caracol (2,92 a 2,94 Ga; Leite et al. 2004) e possivelmente pelo Granodiorito Rio Maria (Oliveira et al. 2009a).

Nesse contexto, a presença de corpos de olivina-hercinita-clorita-(Mg) hornblenda xisto com olivina fortemente estirada, semelhantes a peridotitos do manto superior mais comumente associados a sequências ofiolíticas desmembradas, espacialmente relacionados com o limite dos domínios tectônicos Carajás e Rio Maria, pode sugerir associação com antiga zona de sutura, resultante de subducção de sul para norte, na qual fragmentos de crosta oceânica foram também amalgamados aos proto-continentes. 


\section{CONCLUSÕES}

Na região de Água Azul do Norte, as rochas do Grupo Sapucaia podem ser divididas em três unidades: (i) unidade metaultramáfica (antofilita-clorita-tremolita xistos, magnesiocummingtonita-clorita xistos, clorita-actinolita xistos, serpentinitos e clorititos); (ii) unidade máfica (Mg-hornblenda/hornblenda anfibolitos e quartzo-clorita xistos); e (iii) unidade metassedimentar (biotita-muscovita xisto com almandina).

As rochas metaultramáficas podem ser classificadas como komatiítos peridotitícos e basaltos komatíticos, baseado nos estudos geoquímicos, porém, é preciso cautela nessa definição, já que as mesmas não apresentam características texturais, tais como, texturas spinifex típica desses litotipos. Adicionalmente, é possível que tenham sido derivadas de protólitos com composição de komatiítos e basaltos komatiíticos (antofilita-clorita-tremolita xistos) e olivina cumulatos (serpentinitos e magnesio-cummingtonita-clorita xistos).

As paragêneses metamórficas são indicativas de condições de fácies xisto verde a anfibolito inferior. Processos metassomáticos atuaram variavelmente, principalmente em contato com granitoides e gnaisses em zonas de cisalhamento regionais, resultando em litotipos representativos de alteração do tipo blackwall, tais como clorita-actinolita xistos distais e clorititos proximais.

As semelhanças geoquímicas das rochas menos metassomatisadas (clorita-tremolita xistos) com os komatítos do tipo Barbeton, tais como razões $\mathrm{Gd} / \mathrm{Y} \mathrm{b}_{\mathrm{N}}>1$, sugerem formação a partir da fusão do manto peridotítico com majorita no resíduo. As anomalias positivas de $\mathrm{Nb}$ desses litotipos podem indicar proveniência de plumas mantélicas com adição de material do slab reciclado em profundidades relativamente grandes. Por sua vez, a assinatura química distinta dos antofilita-Mg-cummingtonita xistos (baixo conteúdo de ETR, razões $\mathrm{Gd} / \mathrm{Yb}_{\mathrm{N}}$ mais baixa e anomalias negativas de $\mathrm{Nb}$ ) não pode ser atribuída apenas à contaminação crustal ou metassomatismo e é sugestiva de derivação de pluma heterogênea com múltiplos componentes.

O olivina-hercinita-clorita-( $\mathrm{Mg})$ hornblenda xisto com olivina fortemente deformada indica deformação dúctil de alta temperatura em condições de fácies anfibolito superior a granulito, revelando trajetória metamórfica diferente das demais unidades atribuídas ao Greenstone Belt Sapucaia. A semelhança desses litotipos com peridotitos do manto superior, mais comumente associados a sequências ofiolíticas desmembradas, pode sugerir associação com antiga zona de sutura. 
Os granitoides que representam o embasamento granito-gnáissico-migmatítico previamente inseridos no Complexo Xingu, caracterizados como biotita gnaisses, assemelham-se aos de suítes do tipo TTG com assinatura química similar a de granitos de arcos vulcânicos (VAG) e da média da crosta continental arqueana. Sua evolução pode ser inferida a partir da fusão de metabasaltos hidratados a pressões elevadas (acima de 12 kbar), compatíveis com estabilidade da granada e anfibólio no resíduo. Adicionalmente, hornblendabiotita granito foliado, que são metaluminosos, ferrosos, enriquecidos em $\mathrm{Zr}$, com média razão $\mathrm{Rb} / \mathrm{Sr}$, e baixa razão $\mathrm{Sr} / \mathrm{Y}$ e $\mathrm{La} / \mathrm{Yb}$, assemelha-se a granitos do tipo A de ambiente intraplaca, tais como os granitos alcalinos da Suíte Planalto, de idade 2,72 a 2,73 (Feio et al. 2013), que representa extenso magmatismo neoarqueano reconhecido apenas no Domínio Carajás. Assim, o conjunto de litotipos reconhecidos na região de Água Azul do Norte, entre os domínios tectônicos Rio Maria e Carajás, pode registrar resquícios de platôs ou ilhas oceânicas, representadas pelo Greenstone Belt Sapucaia, amalgamados aos proto-continentes durante o Mesoarqueano. 


\section{REFERÊNCIAS}

Agrawal, S; Guevara, M; Verma, S. 2008. Tectonic discrimination of basic and ultrabasic volcanic rocks through log-transformed ratios of immobile trace elements. International Geology Review 50, 1057-1079.

Almeida, F.F.M.; Hasui, Y.; Brito Neves, B.B. \& Fuck, R.A. 1981. Brasilian structural provinces: an introduction. Earth-Science Reviews, 17:1-29.

Almeida, J.A.C. 2005. Geologia, Petrografia e Geoquímica do Granito Anorogênico Bannach, Terreno Granito-Greestone de Rio Maria - Pará. Belém, UFPA. Centro de Geociências. (Dissertação de Mestrado).

Almeida, J.A.C. 2010. Geologia, geoquímica, geocronologia e petrogênese das suítes TTG e dos leucogranitos arqueanos do Terreno Granito-Greenstone de Rio Maria, sudeste do Cráton Amazônico. Tese (Doutorado em Geoquímica e Petrologia) - Programa de Pós-Graduação em Geologia e Geoquímica, Instituto de Geociências, Universidade Federal do Pará, Belém.

Almeida, J.A.C.; Dall’Agnol R.; Oliveira M.A.; Macambira M. B.; Pimentel, M.M.; Rämö, O.T.; Guimarães, F.V.; Leite, A.A.S. 2011. Zircon geochronology and origin of the TTG suites of the Rio Maria granite-greenstone terrane: Implications for the growth of the Archean crust of the Carajás province, Brazil. Precambrian Research, 187:201-221.

Althoff, F.J.; Barbey, P.; Boullier, A.M. 2000. 2.8-3.0 Ga plutonism and deformation in the SE Amazonian craton: the Archean granitoids of Marajoara (Carajás Mineral province, Brazil). Precambrian Research 104, 187-206.

Anhaeusser, C.R. 1971. The Barberton Mountain Land South Africa-a guide to the understanding of the Archaean geology of Western Australia. Geol. Soc. Austr. Spec. Publ. 3, pp. 103-120.

Anhaeusser, C.R. 1982. Archean greenstone terranes: geologic evolution and metalogenesis. Revista Brasileira de Geociências, v. 12 (1-3), 1-6, Mar-Set. 1982.

Araújo, O.J.B.; Maia, R.G.N. 1991. Serra dos Carajás, Folha SB-22-Z-A. Relatório Final. CPRM, Rio de Janeiro, 136p.

Araújo, O.J.B.; Maia, R.G.N.; Jorge-João, X.S.; Costa, J.B.S. 1988. A megaestruturação da folha Serra dos Carajás. In: Congr. Latino Am. Geol., 7, pp. 324-333.

Arndt, N.; F.; Nisbet, E. 1997. Mafic and ultramafic magmatism. In: De Wit, M.J., Ashwal L.D. (Eds.), Greenstone Belts, Oxford University Press, Oxford, pp. 233-254.

Arndt, N; Lesher, M.C; Barnes, J.S. (eds) 2008. Komatiite. Cambridge University Press, Cambridge, U.K., 467 p.

Avelar, V. G.; Lafon, J. M.; Correia Jr., F. C.; Macambira, E. M. B. 1999. O magmatismo arqueano da região de Tucumã - Província Mineral de Carajás: novos resultados geocronológicos. Revista Brasileira de Geociências, v. 29, n. 4, p. 453-460.

Avelar, V.O. 1996. Geocronologia Pb-Pb por evaporação em monocristal de zircão do magmatiwsmo da região de Tucumã, SE do Estado do Pará, Amazônia oriental. Dissertação de Mestrado, Universidade Federal do Pará, 149p.

Ayres, L. D., Trurston, P.C. 1985. Archean supracurstal sequences in the Canadian Shield: an overview. In: Evolution of Archean Supracrustal Sequences (eds Ayres, L. D., Trurston, P.C., Card, K.D., Weber, W.) Geol. Ass. Can. Spec. Pap 28: 343-380.

Barbosa, A.A.; Lafon, J.M.; Neves.A.P. ;Vale, A.G. 1995. Geocronologia $\mathrm{Rb}-\mathrm{Sr}$ e Pb-Pb do Granito Redenção, SE do Pará: Implicações para a evolução do magmatismo proterozóico 
da região de Redenção. Boletim do Museu Paraense Emílio Goeldi, v. 7, p. 147-164, 1995. (Série Ciências da Terra, 7).

Barbosa, J.P.O. 2004. Geologia Estrutural, Geoquímica, Petrografia e Geocronologia de granitóides da região do Igarapé Gelado, norte da Província Mineral de Carajás. Dissertação de Mestrado, UFPA, 96p.

Barker, F.; Arth, J.G. 1976. Generation fo trondhjemitic-tonalitic liquids and Archean bimodal trondhjemite-basalt suites. Geology, 4, 596-600.

Barros, C.E.M. 1997. Pétrologie et structure du Complexe Granitique Estrela (2.5 Ga) et de son encaissant métavolcano-sédimentaire (Province Métallifêre de Carajás, Brèsil). Nancy, 1997. 316 f. Tese (Doutorado) - Université Henri Poincaré, Nancy, 1997.

Barros, C.E.M.; Macambira, M.J.B.; Barbey, P.; Scheller, T. 2004. Dados isotópicos Pb-Pb em zircão (evaporação) e Sm-Nd do Complexo Granítico Estrela, Província Mineral de Carajás, Brasil: Implicações petrológicas e tectônicas. Revista Brasileira de Geociências 34, 531-538.

Barros, C.E.M; Barbey, P. 1998. A importância da granitogênese tardi-arqueana (2.5 Ga) na evolução tectono-metamórfica da Província Mineral de Carajás - o Complexo Granítico Estrela e sua auréola de contato. Revista Brasileira de Geociências, v. 28, n. 4, p. 513-522, 1998.

Barth, M. G. 2007. Composition and Evolution of the Lithosphere. Universität Mainz.

Bateman, R; Costa, S; Swe, T; Lamber, D. 2001. Archaean mafic magmatism in the Kalgoorlie area of the Yilgarn Craton, Western Australia: a geochemical and Nd isotopic study of the petrogenetic and tectonic evolution of a greenstone belt. Precambrian Res., 108:75-112.

Boynton, W.V. 1984. Geochemistry of the rare earth elements: meteorite studies. In P. Henderson (ed.) Rare Earth Element Geochemistry. Amsterdam, Elsevier, 63-114.

Bucher, K.; Frey, M. 1994. Petrogenesis of Metamorphic Rocks. Springer- Verlag Berlin Heidelberg, 318p.

Bucher, K.; Grapes, R. 2011. Petrogenesis of Metamorphic Rocks. Springer, 8th edition, 428p.

Bucher-Nurminen, K. 1988. Caledonian metamorphism of ultramafic rocks in the Central Scandinavian Caledonides. Nor. Geol. Unders. Special Publ. 3. 86-95.

Cavalcanti, G.C.G; 2007. Mapeamento Estrutural das Rochas Vulcânicas e Graníticas Adjacentes ao Garimpo Canadá, a Sul da Serra dos Carajás (PA). Trabalho de Conclusão de Curso (TCC). Universidade Federal do Pará.

Condie, K. C. 1994. Archean Crustal Evolution. Editora: Elsevier. Amsterdam

Condie, K.C. 1981. Archean Greenstone Belts. Elsevier, Amsterdam, 434 pp.

Condie, K.C. 1989. Geochemical Changes in Basalts and Andesites Across the ArcheanProterozoic Boundary: Identification and Significance. Lithos, 23: 1-18.

Condie, K.C. 2001. Mantle Plumas e seu registro na história da Terra. Cambridge University Press, Cambridge, Reino Unido, 305 p.

Condie, K.C.; Kröner, A. 2013. The building blocks of continental crust: Evidence for a major change in the tectonic setting of continental growth at the end of the Archean. Gondwana Research, 23, 394-402. 
Cordani, U. (1981). Comentários sobre as determinações geocronológicas da região da Serra dos Carajás. Report, Universidade de São Paulo-Docegeo.

Cordeiro, A.C. \& Saueressing, R.. 1980. Serra das Andorinhas: Geologia e Principais ocorrências de Ouro. In: Congresso Brasileiro de Geologia, 31, Camboriú. Resumos... Camboriú: SBG. Boletim 2, p. 344.

Cordeiro, A.C. 1982. Geologia preliminar da região de Andorinhas. In: Simpósio de Geologia da Amazônia, 1, Belém, 1982. Anais..., Belém, SBG. v. 1, p. 45-49.

Cousens, B.; Facey, K.; Falck, H. 2002. Geochemistry of the late Archean Banting Group, Yellowknife greenstone belt, Slave Province, Canada: simultaneous melting of the upper mantle and juvenile mafic crust. Can. J. Earth Sci., 39:1635-1656.

Cunha, B.C.C.; Santos, D.B.; Prado, P. 1984. Contribuição ao estudo da estratigrafia da região dos Gradaús, com ênfase no Grupo Rio Fresco. In: CONGRESSO BRASILEIRO DE GEOLOGIA, 33, 1984, Rio de Janeiro. Anais... Rio de Janeiro: SBG, 1984. v. 2, p. 873-885.

Dall'Agnol, R.; Oliveira, D.C.; Guimarães, F.V.; Gabriel, E.O.; Feio, G.R.L.; Lamarão, C.N.; Althoff, F.J.; Santos, P.A.; Mayara, F.B.; Silva, A.C.; Rodrigues, D.S.; Santos, M.J.P.; Silva, C. R.P.; Santos, R.D.; Santos, P.J.L. 2013. Geologia do subdomínio de transição do domínio Carajás - implicações para a evolução arqueana da Província Carajás - Pará. In: Simpósio de Geologia da Amazônia, 13, 2013. Belém. Resumos expandidos... Belém: SBG, p. 1082-1085.

Dall'Agnol, R.; Oliveira, M.A. De; Almeida, J. De A.C. De; Althoff, F.J.; Leite, A.A. Da S.L.; Oliveira, D.C.; Barros, C.E de M. 2006. Arquean and Paleoproterozoic granitoids of the Carajás Metallogenic Province, eastern Amazonian Craton. In: Symposium on magmatism, crustal evolution, and matallogenesis of the Amazonian Craton. Belém, PRONEXUFPA/SBG-NO, p 97-150.

Dall'agnol, R.; Scaillet, B.; Pichavant, M. 1999a. "Evolution of A-type granite magmas: an experimental study of the Lower Proterozoic Jamon Granite, eastern Amazonian craton, Brazil". Journal of Petrology. 40 (11) 1673-1698.

Dardenne, M.A.; Schobbenhaus, C.S. 2001. Metalogênese do Brasil. Editora Universidade de Brasília/CNPq, Brasília, 392 p

De Wit, M.J., Ashwal L.D. 1997. Greenstone Belts, Oxford University Press, Oxford, (Eds.) pp. 233-254.

Deer, W. A.; Howie, R.A.; Zussman, J. 1992. An introduction to the rock-forming minerais. 2ed. New York, Longman Scientific \& Technical, 696p.

Deer, W.A.; Howie, R.A.; Zussman, J. 1997. Rock-Forming Minerals. v1A. 2nd edition. The Geological Society, Londres. 919 pp.

Dias, G.S.; Macambira, M.B.; Dall'Agnol R.; Soares, A.D.V.; Barros, C.E.M. 1996. Datações de zircões de sill de metagabro: comprovação de idade arqueana da Formação Águas Claras, Carajás, Pará. In: V Simpósio de Geologia da Amazônia, SBG, pp 376-378.

Dias, S.B. 2009. Caracterização geológica, petrográfica e geoquímica de granitos Arqueanos da Folha Marajoara, terreno granito-greenstone de Rio Maria, sudeste do Pará. Dissertação de Mestrado, Programa de Pós-graduação em Geologia e Geoquímica, Instituto de Geociências, Universidade Federal do Pará, Belém, 129p.

DOCEGEO, 1988. Revisão litoestrátigráfica da Província Mineral de Carajás. In: BG, Congr. Bras. Geol., 25, Belém, Anexo, 10-54. 
Draut, A.E., Clift, P.D., Hannigan, R.E., Layne, G., Shimizu, N. 2002. A model for continentalcrust genesis by arc accretion: rare earth element evidence fromthe Irish Caledonides. Earth and Planetary Science Letters, 203: 861-877.

Draut, A.E.; Clift, P.D.; Amato, J.M.; Blusztajn, J.; Schouten, H. 2009. Arc-continent collision and the formation of continental crust: a new geochemical and isotopic record from the Ordovician Tyrone Igneous Complex, Irland. Journal of the Geological Society of London, 166: 485-500.

Duarte, K.D.; Pereira, E.D.; Dall'Agnol, R.; Lafon, J.M. 1991. Geologia e geocronologia do Granito Mata Surrão - sudoeste de Rio Maria (PA). In: Simpósio De Geologia da Amazônia, 3, Belém. Anais... Belém: SBG-Núcleo Norte, 1991. p. 7-20.

Evans, B.W. 2004. The serpentinite multisystem revisited: chrysotile is metastable. International Geology Review, 46 (2004), pp. 479-506

Faresin, A.C.; Oliveira, D.C.; Macambira, M.J. B. 2010. Geologia e geocronologia das rochas granitoides do complexo Xingu e da sequência greenstone belt da região de nova CanadáProvíncia Mineral de Carajás. In: SBG, Congresso Brasileiro de Geologia, 45, Anais, Belém, CDrom.

Feio, G. R. L. 2011. Magmatismo granitoide arqueano da área de Canaã dos Carajás: implicações para a evolução crustal da Província Carajás. Tese (Doutorado em Geoquímica e Petrologia) - Programa de Pós-Graduação em Geologia e Geoquímica, Universidade Federal do Pará, Belém, 190 f.

Feio, G.R.L.; Dall'Agnol R.; Dantas E.L.; Macambira M.J.B.; Santos J.O.S.; Althoff F.J. 2013. Archean granitoid magmatism in the Canaã dos Carajás area: Archean granitoid magmatism in the Canaã dos Carajás area: Implications for crustal evolution of the Carajás province, Amazonian craton, Brazil. Precambrian Research, 227 (2013) 157-185.

Ferreira-Filho, C.F.; Cançado, F.; Correa, C.; Macambira, E.M.B.; Siepierski, L.; JunqueiraBrod, T.C. 2007. Mineralizações estratiformes de EGP-Ni associadas a complexos acamadados em Carajás: os exemplos de Luanga e Serra da Onça. In: Rosa-Costa, L.T, Klein, E.L.; Viglio, E.P. (Org.). Contribuições à Geologia da Amazônia, Belém-PA, Publitec Gráfica \& Editora, 5: 1-14.

Ford, F.D.; Skippen, G.B. 1997. Petrology of the Flinton Creek metaperidotites: enstatitemagnesite and anthophyllite-magnesite assemblages from the Grenville Province. The Canadian Mineralogist, 35: 1221-1236.

Frost, B.R., Barnes, C., Collins, W., Arculus, R., Ellis, D., Frost, C., 2001. A chemical classification for granitic rocks. Journal of Petrology 42, 2033-2048.

Gabriel, E.O. 2012. Geologia, geoquímica e petrologia magnética dos granitoides arqueanos da porção nordeste de Água Azul do Norte (PA) - Província Carajás. Dissertação de Mestrado, Programa de Pós-graduação em Geologia e Geoquímica, Instituto de Geociências, Universidade Federal do Pará, Belém, 107p.

Gabriel, E.O.; Oliveira D.C.; Galarza M.A. 2010. Petrografia e Geocronologia de granitoides do Complexo Xingu da região nordeste de Água Azul do Norte, Província Mineral de Carajás, In: SBG, Congresso Brasileiro de Geologia, 45, Anais, Belém, CDrom.

Galarza, M.A.; Macambira, M.J.B. 2002a. Petrologia e geocronologia das rochas encaixantes do depósito de $\mathrm{Cu}-\mathrm{Au}$ Igarapé Bahia, Província Mineral de Carajás, Pará, Brasil. In: Klein, E. L.; Vasquez, M. L.; Rosa-Costa, L. T. (Ed.). Contribuições à geologia da Amazônia. Belém: SBG-Núcleo Norte, v. 3, p. 153-168. 
Galarza, M.A.; Macambira, M.J.B. 2002b. Geocronologia e evolução crustal da área do depósito de $\mathrm{Cu}-\mathrm{Au}$ Gameleira, Província Mineral de Carajás (Pará), Brasil. Revista do Instituto de Geociências da USP, v. 2, p. 143-159. (Geologia, Série Científica).

Galarza, M.A.; Oliveira D.C.; Santos R.D.; Martins A.C.; Santos A.N.; Santos P.J.L. 2012. Geocronologia do Diopsídio-Norito Pium e granitoides associados, Canaã dos Carajás, Província Carajás. In: SBG, Congresso Brasileiro de Geologia, 46, Santos-SP, CDrom.

Glikson, A.Y. 1976. Stratigraphy and evolution of primary ande secondary greenstones: significance of data from shields of the southern hemisphere. Pp 527-277. In B.T. Windley, (ed). The Early History of the Early. Wiley, New York, 619 pp.

Goldfarb, R.; Groves, D.I.; Gardoll, S. 2001. Orogenic gold and geologic time: a global synthesis. Ore Geology. Rev., 18:1-75.

Gole, M.; Barnes, S.J.; Hill, R.E.T. 1987. The role of fluids in metamorphism of komatiites, Agnew nickel deposit, Western Australia. Contrib. Mineral. Petrol. 96, 151-162.

Grant, J. A. 1986. The isocon diagram; a simple solution to Gresens' equation for metasomatic alteration. Economic Geology, 81,1976-1982.

Gresens, R. L. 1967. Composition-volume relationships of metasomatism. Chemical Geology, 2, 47-65.

Groves, D.I.; Goldfarb, R.J.; Gebre-Mariam, M.; Hagemann, S.G.; Robert, F. 1998. Orogenic gold deposits: A proposed classification in the context of their crustal distribution and relationship to other gold deposit types. Ore Geology. Rev., 13:7-27.

Hamilton, W.B. 2011. Plate tectonics began in Neoproterozoic time, and plumes from deep mantle have never operated. Lithos, 123 (2011) 1-20.

Hanski, E; Huhma, H. 2005. Central Lapland greenstone belt. In: Lehtinen M, Nurmi PA, Rämö OT (eds) Precambrian Geology of Finland - Key to the Evolution of the Fennoscandian Shield. Elsevier Science B.V, Amsterdam, pp 139-193.

Hastie, A.R.; Kerr, A.C.; Pearce, J.A.; Mitchell, S.F. 2007. Classification of altered volocanic island arc rocks using immobile trace elements: development of the Th Co discrimination diagram. Journal of Petrology 48, 2341-2357.

Hirata, W.K.; Rigon, J.C.; Kadekaru, K.; Cordeiro, A.A.C., Meireles, E.M. 1982. Geologia Regional da Província Mineral de Carajás. In: Simpósio de Geologia da Amazônia, 1, Belém, 1982. Anais..., Belém, SBG. v. 1, p. 100-110.

Hoffman, P.F., 1990. Precambrian geology and tectonic history of North America. In: The Geology of North America: an Overview. The Geology of North America, vol. A, Geological Society of America, pp. 447-512.

Hughes, C.J. 1973. Spilites, keratophyres and the igneous spectrum. Geological magazine, vol 109, no 6, pp 513-527.

Huhn, S.B.; Macambira, M.J.B; Dall'agnol, R. 1999. Geologia e Geocronologia Pb/Pb do granito Alcalino Arqueano Planalto, Região da Serra do Rabo, Carajás- PA. In: Simp. Geol. Amazonias, 6. Manaus, Anais...SBG. (1). p. 463-466.

Huhn, S.R.B., Nascimento, J.A.S. 1997. São os depósitos cupríferos de Carajás do tipo CuAu-U-ETR? In: Costa, M.L., Angélica, R.S. (Coord.). Contribuições à geologia da Amazônia. Belém: SBG-Núcleo Norte, 1997. v. 1, p. 143-160.

Huhn, S.R.B.; Santos,A.B.S.; Amaral, A.F.; Lendshan, E.J.; Gouvêa, J.L.; Martins, L.P.B; Montalvão, R.M.G.; Costa, V.G.1988. O terreno "granito greenstone" da região de Rio Maria 
- sul do Pará. In: Congresso Brasileiro de Geologia, 35, 1988, Belém. Anais... Manaus: SBGNúcleo Norte, v. 3, p. 1438-1452.

Ianhez, A.C.; Souza, A.M.S.; Montalvão, R.M.G. 1980. Geologia da sequiência vulcanosedimentar da Serra do Inajá - Santana do Araguaia. In: CONGRESSO BRASILEIRO DE GEOLOGIA, 31, Camboriú, 1990. Anais... Camboriú, SBG. v.5, p.2918- 2928.

Irvine, T.N.; Baragar, W.R.A. 1971. A guide to the chemical classification of the common volcanic rocks. Canadian of Journal Earth Sciences 8, 523-547.

Janoušek, V.; Farrow, C. M.; Erban, V.; Trubač, J. 2011. Brand new Geochemical Data Toolkit (GCDkit 3.0) - is it worth upgrading and browsing documentation? (Yes!). Geol. Výzk. Mor. Slez, 18, 26-30.

Jensen, L.S. 1976. A new method of classifying alkalic volcanic rocks. Ont. Div. Min., Misc. Pap., 66, 22 pp.

Jorge João, X.S.; Neves, A.P.; Leal, J.W.L. 1982. Ouro da Serra Pelada: aspectos da geologia e garimpagem. In: Simpósio De Geologia Da Amazônia, 1., Belém. Anais... Belém: SBGNúcleo Norte, v. 2, p. 52-62.

Kerr, P. 1959. Optical Mineralogy. New York, McGraw-Hill Book Co. 3ed.492p.

Kroner, A. 1982. Archaean to early Proterozoic tectonics and crustal evolution: a review. Revista Brasileira de Geociências, 12 (1-3):15-31, Mar-Set. São Paulo.

Krymsky, R.S.; Macambira, J.B.; Macambira, M.J.B. Geocronologia. 2002. U-Pb em zircão de rochas vulcânicas da Formação Carajás, Estado do Pará. In: Simpósio De Vulcanismo E Ambientes Associados, 2., 2002. Belém. Resumos... Belém: PRONEX/SBG, 2002. p. 41.

Lafon, J.M.; Macambira, M.J.B.; Pidgeon, R.T. 2000. Zircon U-Pb SHRIMP dating of Neoarchean magmatism in the southwestern part of the Carajás Province (eastern Amazonian Craton, Brazil). In: International Geological Congress, 31., 2000, Rio de Janeiro. Abstracts... Rio de Janeiro, 1 CD-ROM.

Lafon, J.M.; Scheller, T. 1994. Geocronologia $\mathrm{Pb} / \mathrm{Pb}$ em zircão do Granodiorito Cumaru, Serra dos Gradaús, PA. In: Simpósio De Geologia Da Amazônia, 4., 1994, Belém. Resumos expandidos... Belém: SBG-Núcleo Norte, p. 321-323.

Le Bas, M.J.; Le Maitre, R.W.; Streckeisen, A.; Zanettin, B. 1986. A chemical classification of volcanic rocks based on the total alkali-silica diagram. J. Petrol., 27: 745-750.

Le Maitre, R. W.; Bateman, P.; Dudek, A.; Keller, J.; Lameyre, J.; Le Bas, M. J.; Sabine, P. A.; Schmid, R.; Sørensen, H.; Streckeisen, A.; Woolley, A. R.; Zanettin, B. 1989. A Classification of Igneous Rocks and Glossary of Terms, Oxford, Blackwell, p. 191.

Lee, C.T.A.; Morton, D.M.; Kistler, R.W.; Baird, A.K. 2007. Petrology and tectonics of Phanerozoic continent formation: from island arc to accretion and continental arc magmatism. Earth and Planetary Science Letters, 263, 370-387.

Leite A.A.S.; Dall'Agnol R.; Macambira M.J.B.; Althoff F.J. 2004. Geologia e geocronologia dos granitoides arqueanos da região de Xinguara-PA e suas implicações na evolução do Terreno Granito-Greenstone de Rio Maria, Cráton Amazônico. Revista Brasileira de Geociências, 34 (4):447-458.

Leite, A.A.S. 2001. Geoqúimica, petrogênese e evolução estrutural dos granitoides arqueanos da região de Xinguara, SE do Cráton Amazônico. Belém, Centro de Geociências, 
Universidade Federal do Pará, 330p. Tese de doutorado. Curso de Pós-graduação em Geologia e Geoquímica, Centro de Geociências, UFPa.

Leite, A.A.S.; Dall' Agnol, R.; Althoff, F. J.; Almeida, J.A.C. 2010. Geoquímica e petrogênese dos granitóides TTG e leucogranitos potássicos arqueanos da região de Xinguara, terreno granito-greenstone de Rio Maria, Pará. In: 45 Congresso Brasileiro de Geologia, 2010, Belém. Cd-rom.

Leite, A.A.S.; Dall'agnol, R. 1997. Geologia e petrografia do maciço granítico Arqueano Xinguara e de suas encaixantes - SE do Pará. Boletim do Museu Paraense Emílio Goeldi, v. 9, p. 43-81 (Série Ciências da Terra).

Leite, A.A.S.; Dall'Agnol, R.; Macambira, M.J.B.; Althoff, F.J. 2004. Geologia e geocronologia dos granitoides arqueanos da região de Xinguara-PA e suas implicações na evolução do Terreno Granito-Greenstone de Rio Maria, Cráton Amazônico. Revista Brasileira de Geociências, 34(4):447-458.

Lindenmayer, Z. G. 1990. Salobo sequence, Carajás, Brazil: geology, geochemistry and metamorphism. Ontario, University of Western Ontario. 408 p. (Ph. D. Thesis).

Lindenmayer, Z.G. and Teixeira, J.B.G., 1999 - Ore genesis at the Salobo Copper deposit, Serra dos Carajás; in Silva, M.G. and Misi, A. (eds.), Base Metal Deposits of Brazil, MME/CPRM/DNPM, pp. 33-43.

Lowe, D.R. 1980. Stromatolites 3,400-Myr old from the Archean of Western Australia: Nature, v. 284, p. 441-443.

Lowe, D.R. 1982. Comparative Sedimentology of the Principal Volcanic Sequences of Archean Greenstone Belts in South Africa, Western Australia, and Canada: Implications for Crustal Evolution. Precambrian Research., 17: 1-29.

Lowe, D.R.1994. Archean greenstone-related sedimentary rocks. In: Condie, K.C. (Ed.), Archean crustal evolution. Elsevier, Amsterdam. pp. 121169.

Macambira M.J.B.; Costa J.B.S.; Althoff F.J.; Lafon J.M.; Melo J.C.V.; Santos A. 2000. New geochronological data for the Rio Maria TTG terrane; implications for the time contraints of the crustal formation of the Carajás province, Brazil. In: International Geological Congress, 31 st, Rio de Janeiro, 2000, CD-ron abstract volume.

Macambira, E.M.B.; Vale, A.G. 1997. São Félix do Xingu: folha SB.22-Y-B, Estado do Pará, escala 1:250.000. Texto Explicativo. Brasília: CPRM, 344 p., il. Programa Levantamentos Geológicos Básicos do Brasil (PLGB).

Macambira, J.B.; Kotschoubey, B.; Santos, M.D.; Moura, C.A.V.; Ramos, J.F.F. 1986. Estratigrafia e mineralizações primárias de ouro da aba sul do sinclinório de Gradaús - sul do Pará. In: Congresso Brasileiro de Geologia, 34., 1986, Goiânia. Anais... Goiânia: SBG, 1986. v. 5, p. 1956-1968.

Macambira, M.J.B.; Lancelot, J. 1991. Em busca do embasamento arqueano da região de Rio Maria, sudeste do Estado do Pará. In: Simpósio de Geologia da Amazônia, 3, Belém, 1991. Resumos... Belém. SBG. p.49-58.

Macambira, M.J.B.; Lancelot, J. 1996. Time constraints of Archean Rio Maria crust, Southeastern Amazonian Craton, Brazil. Intern. Geol. Rev., 38 (12): 1134-1142.

Machado, N.; Lindenmayer, Z.; Krogh, T.H.; Lindenmayer, D. 1991. U-Pb geoehronology of Archaean magmatism and basement reactivation in the Carajás área, Amazon shield, Brazil. Precambrian Research, 49: 329-354. 
Marangoanha, B.; Oliveira, D.C. 2013. Geologia, geoquímica e petrologia magnética do magmatismo máfico de Nova Canadá (Pa), Província Carajás. In: Simpósio de Geologia da Amazônia, 13, 2013. Belém. Resumos expandidos... Belém: SBG, p. 258-261.

Marinho, P.A.C. (Org). 1977. Projeto Carvão no Rio Fresco: relatório final. Belém: CPRM, v. 1,126 .

Martin, H. 1994. The Archean grey gneisses and the gneisses of continental crust. In: CONDIE, K. C. (ed.) Developments in precambrian geology 11. Archean crustal evolution, Amsterdam, Elsevier. p. 205-259.

Martin, H. 1999. The adakitic magmas: modern analogues of Archaeangranitoids. Lithos, 46, 411-429.

Martin, H.; Smithies, R.H.; Rapp, R.; Moyen, J.F.; Champion, D. 2005 An overview of adakite, tonalite-trondhjemite-granodiorite (TTG) and sanuktoid: relationship and some implications for crustal evolution. Lithos, 79, 1-24

Medeiros, H.; Dall'Agnol, R. 1988. Petrologia da porção leste do batólito Granodiorítico Rio Maria, sudeste do Pará. In: SBG, Congresso Brasileiro de Geologia, 35, Anais, Belém, v.3, p.1488-1499.

Medeiros-Filho, C.A.; Meirelles, E.M. 1985. Dados preliminares sobre a ocorrência de cromita na área Luanga. In: Simpósio De Geologia Da Amazônia, 2., Belém. Anais... Belém: SBG-Núcleo Norte, 1985. v. 3, p. 90-96.

Mehnert, K.R. 1968. Migmatites and the origino g granítica rocks. Elsevier Publishing Company, Amsterdan, 393 p.

Monteiro, L.V.S.; Xavier, R.P.; Hitzman, M.W.; Juliani, C.; Souza-Filho, C.R.; Carvalho, E.R. 2008. Mineral chemistry of ore and hydrothermal alteration at the Sossego iron oxidecopper-gold deposit, Carajás Mineral Province, Brazil. Ore Geol Rev 34:317-336

Monteiro, P.M.; Rolando A.P.; Macambira, M.J.B. 2004. Proveniência de zircão de quartzitos da Formação Gorotire e Grupo Rio Fresco, serra do Inajá, sul da Província Mineral do Carajás. In: Congresso Brasileiro De Geologia, 42, Araxá. Resumos... Araxá: SBG, 2004. 1 CD-ROM

Moreto C.P.N.; Monteiro, L.V.S.; Xavier, R.P.; Amaral, W.S.; Santos, T.J.S.; Juliani, C.; Souza-Filho, C.R. 2011. Mesoarchean (3.0 and 2.86 Ga) host rocks of the iron oxide-Cu-Au Bacaba deposit, Carajás Mineral Province: $\mathrm{U}-\mathrm{Pb}$ geochronology and metallogenetic implications. Mineralium Deposita, 46:789-811.

Moreto, C.P.N. 2013. Geocronologia U-Pb e Re-Os aplicada à evolução metalogenética do Cinturão Sul do Cobre da Província Mineral de Carajás. Tese de doutorado. Universidade Estadual de Campinas, Campinas-SP. 250 pp.

Moreto, C.P.N., Monteiro, L.V.S., Xavier, R.P., Melo, G.H.C., Silva, M.A.D. 2013. Multiple hydrothermal and iron oxide $\mathrm{Cu}-\mathrm{Au}$ systems in the Southern Copper Belt, Carajás Province. In: III Simpósio Brasileiro de Metalogenia, Gramado [CD-ROM].

Mougeot, R.; Respaut, JP.; Briqueu, L.; Ledru, P.; Milesi, J.P.; Macambira, M.J.B.; Huhn, S.B. 1996. Geochronological constrains for the age of the Águas Claras Formation (Carajás Province, Pará, Brazil). In: Cong. Bras. Geol., 39, Salvador, 1996. Anais, Salvador, SBG. 6, pp 579-581.

Moyen, J.F; Martin, H. 2012. Forty years of TTG research. Lithos, 148 (2012) 312-336.

Naldrett, A.J. 2004. Magmatic sulfide deposits. Springer, Heidelberg, 728 pp. 
Nesbitt, R. W. 1971. Skeletal crystal forms in the ultramafic rocks of the Yilgarn Block, Western Australia: Evidence for an Archaean ultramafic liquid. Geol. Soc. Australia, v. 3, p. 331-347.

Neves, S.P. 2001. Dinâmica do Manto e Deformação Continental: Uma Introdução a Geotectônica. Recife: Editora. Universitário da UFPE.

Nogueira, A.C.R.; Truckenbrodt, W.; Pinheiro, R.V.L. 1995. Formação Águas Claras, PréCambriano da Serra dos Carajás: redescrição e redefinição litoestratigráfica. Bol. Mus. Par. Em. Goeldi, 7: 177-277.

O'Connor, J.T. 1965. A classification for quartz-rich igneous rocks based on feldspar ratios. US Geological Survey Professional Paper B525. USGS, 79-84.

Oliveira D.C.; Dall'Agnol R.; Barros C.E.M.; Figueiredo, M.A.B.M. 2002. Petrologia magnética do Granito Paleoproterozoico Redenção, SE do Cráton Amazônico. In: E.L Klein, M.L. Vasquez, L.T. Rosa-Costa (eds.) Contribuições à Geologia da Amazônia. Sociedade Brasileira de Geologia Núcleo Norte, Belém, vol.3, p.115-132.

Oliveira, C.G.; Santos, R.V.; Leonardos, O.H. 1995. Geologia e mineralização aurífera do greenstone belt Sapucaia, sudeste do Pará. Boletim do Museu Paraense Emílio Goeldi, v. 7, p. 61-91.

Oliveira, D.C. Modelos de evolução e colocação dos granitos paleoproterozóicos da Suíte Jamon, SE do Cráton Amazônico. 2006. 171 f. Tese (Doutorado) - Centro de Geociências, Universidade Federal do Pará, Belém.

Oliveira, D.C.; Santos, P.J.L.; Gabriel, E.O.; Rodrigues, D.S.; Faresin, A.C.; Silva, M.L.T.; Sousa, S.D.; Santos, R.V.; Silva, A.C.; Souza, M.C.; Santos, R.D.; Macambira, M.J.B. 2010. Aspectos geológicos e geocronológicos das rochas magmáticas e metamórficas da região entre os municípios de Água Azul do Norte e Canaã dos Carajás - Província Mineral de Carajás, In: SBG, Congresso Brasileiro de Geologia, 45, CDrom.

Oliveira, M.A.; Dall'Agnol, R.; Althoff, F.J.; Leite, A.A.S. 2009a. Mesoarchean sanukitoid rocks of the Rio Maria Granite-Greenstone Terrane, Amazonian craton, Brazil. Journal of South American Earth Sciences, 27, 146-160.

Pearce, J.A., Harris, N.B.W., Tindle, A.G. 1984. Trace element discrimination diagrams for the tectonic interpretation of granitic rocks. Journal of Petrology, 25: 956-983.

Peccerillo, A.; Taylor, S.R. 1976. Geochemistry of Eocene calc-alkaline volcanic rocks from the Kastamonu area, Northern Turkey. Contribution to Mineralogy and Petrology 58, 63-81.

Pidgeon, R.T.; Macambira M.J.B.; Lafon J.M. 2000. Th-U-Pb isotopic systems and internal structures of complex zircons from an enderbite from the Pium Complex, Carajás Province, Brazil: evidence for the ages of granulites facies metamorphism and the protolith of the enderbite. Chemical Geology, 166:159-171.

Pimentel M.M.; Machado N. 1994. Geocronologia U-Pb dos Terrenos granito-greenstone de Rio Maria, Pará. In: Congresso Brasileiro De Geologia, 38, Camboriú, 1988. Boletim de Resumos Expandidos. Camboriú, SBG. p. 390-391.

Pimentel, M.M.; Lindenmayer, Z.G; Laux, J.H.; Armstrong, R.; Araújo, J.C. 2003. Geochronology and $\mathrm{Nd}$ geochemistry of the Gameleira $\mathrm{Cu}-\mathrm{Au}$ deposit, Serra dos Carajás, Brazil: 1.8-1.7 Ga hydrothermal alteration and mineralization. J South Am Earth Sci 15:803813 
Polat, A. 2014. Geochemical variations in Archean volcanic rocks, southwestern Greenland: Traces of diverse tectonic settings in the early Earth. Geological Society of America, March 2013; v. 41; no. 3; p. 379-380; doi: 10.1130/focus0320131.1

Polat, A.; Kerrich, R. 2001. Magnesian andesites, Nb-enriched basalt-andesites, and adakites from late Archean $2.7 \mathrm{Ga}$ Wawa greenstone belts, Superior Province, Canada: implications for late Archean subduction zone petrogenetic processes. Contrib. Mineral. Petrol., 141:3652 .

Ramos, J.F.; Moura, C. A. V.; Melo, C. F.; Pereira, J.L.; Serique, J. S-C. B.; Rodrigues, R. M. 1984.Uma discussão sobre sequencias sedimentares tidas como formação Rio Fresco, sudeste do Pará. In: CONGRESSO BRASILEIRO DE GEOLOGIA, 33., Rio de Janeiro, 1984. Resumos ... Rio de Janeiro: SBG, 1984. p. 50-51.

Ramsay, J. G. 1963. Sctructural investigations in the Barbeton Mountain Land, eastern Transvaal. Trans. Geol. Soc. South Africa, 66, p. 353-401.

Reis, F. N.; Macambira, M.J.B.; Villas, R. N.; Krymsky, R. 2001a. Estudo isotópico do Pb do depósito cupro-aurífero de Serra Verde, Província Mineral de Carajás In: Simp. Geol. Amaz. 7, Belém, Res. Expandidos, Sessão Tematica III (Metalogênese/Geologia Econômica), CDRom, SBG , p. 80-83

Réquia, K., Stein, H., Fontboté, L. Chiaradia, M. 2003. Re-Os and Pb-Pb geochronology of the Archean Salobo iron oxide copper-gold deposit, Carajás Mineral Province, northern Brazil. Miner. Dep., 38: 727-738.

Ricci, P.S.F.; Carvalho M.A. 2006. Rocks of the Pium-Area, Carajás Block, Brazil - A Deepseated High-T Gabbroic Pluton (Charnockitoid-Like) with Xenoliths of Enderbitic Gneisses Dated at $3002 \mathrm{Ma}$ - The Basement Problem Revisited. In: Simpósio de Geologia da Amazônia, Boletim de Resumos Expandidos, Belém, SBGeo/NO, cd rom.

Rolando, A.P.; Macambira, M.J.B. 2003. Archean crust formation in Inajá range area, SSE of Amazonian craton, Brazil, based on zircon ages and $\mathrm{Nd}$ isotopes. In: South American Symposium On Isotope Geology, 4., Salvador. Short Papers... Salvador: CBPM, p. 268-270.

Rudnick, R.L.; Gao, S. 2003. Composition of the continental crust. Treatise on Geochemistry, Vol. 3. Elsevier. 1-64.

Saito, S.; Arima, M.; Nakajima, T.; Misawa, K.; Kimura, J.I. 2007. Formation of distinct granitic magma batches by partial melting of hybrid lower crust in the Izu Arc collision zone, Central Japan. Journal of Petrology, 48, 1761-1791.

Santos, A.; Pena-Filho, J.I.C. 2000. Xinguara: folha SB.22- Z-C. Estado do Pará, escala 1:250.000. Brasília: CPRM, 1 CD-ROM. Programa Levantamentos Geológicos Básicos do Brasil (PLGB).

Santos, D.K.C.; Oliveira, D.C. 2010. Geologia, petrografia e estratigrafia da Sequência Greenstone Beltsd Grupo Sapucaia e rochas associadas da região de Nova Canadá, sudeste do Pará, Província Mineral de Carajás, Cratón Amazônico. In: SBG, Congresso Brasileiro de Geologia, 45, Anais, Belém, CDrom.

Santos, J.O.S. 2003. Geotectônica do Escudo das Guianas e Brasil-Central. In: (Ed.) Geologia, tectônica e recursos minerais do Brasil: texto, mapas e SIG. Brasília: CPRMServiço Geológico do Brasil, p. 169-226

Santos, J.O.S.; Hartmann, L.A.; Faria, M.S.; Riker, S.R.; Souza, M.M.; Almeida, M.E.; McNaughton, N.J. 2006. Compartimentação do Cráton Amazonas em províncias: Avanços 
ocorridos no período 2000-2006. In: Simpósio de Geologia da Amazônia, 9.: Belém, 2006, Anais, Belém: SBG, 2006, CD-ROM.

Santos, J.O.S; Hartmann, L.A.; Gaudette, H.E.; Groves, D.I.; McNaughton, N.J.; Fletcher, I.R. 2000. A new understanding of the provinces of the Amazon Craton based on integration of field mapping and U-Pb and Sm-Nd geochronology. Gondwana Research 3, 453-488.

Santos, M.D. 1995. O papel dos granitóides na gênese dos depósitos de ouro tipo lode arqueano: caso da jazida do Cumaru-PA. 1995. 157 f. Tese (Doutorado) - Universidade de Brasília, Brasília.

Santos, M.G.S. 2002. Estudo dos isótopos de $\mathrm{Pb}$ e $\mathrm{Nd}$ do Depósito de $\mathrm{Cu}-\mathrm{Au}$ (U-ETR) Alemão, Provincia Mineral de Carajás (PA). 2002. 126 f. Dissertação (Mestrado) - Centro de Geociências, Universidade Federal do Pará, Belém.

Santos, R.D.; Oliveira, D.C. 2010. Geologia, petrografia e caracterização geoquímica das rochas máficas do Complexo Pium-Província mineral de Carajás. In: Congresso Brasileiro de Geologia, 45, CDrom.

Sardinha A.S.; Dall'Agnol R.; Gomes A.C.B.; Macambira M.J.B.; Galarza M.A. 2004. Geocronologia $\mathrm{Pb}-\mathrm{Pb}$ e U-Pb em zircão de granitoides arqueanos da região de Canaã dos Carajás, Província Mineral de Carajás. In: RBG, Congresso Brasileiro de Geologia, 42, Anais, CDrom.

Sardinha A.S; Barros, C.E.M.; Krymsky, R. S.; Macambira, M.J.B. 2001. Petrografia e geocronologia U-Pb em zircão do Granito Serra do Rabo, Província Mineral de Carajás, Pará. In: Simpósio de Geologia da Amazônia, 7, Belém. Resumos expandidos...Belém: SBGNúcleo Norte, 2001. 1 CD-ROM.

Sardinha, A.S.;Barros, C.E.M.; Krymsky, R. 2006. Geology, Geochemistry, and U-Pb geochronology of the Archean $(2.74 \mathrm{Ga})$ Serra do Rabo granite stocks, Carajás Province, northern Brazil. Journal of South American Earth Sciences 20, 327-339.

Schorscher, J. H. D. 1994. Entwicklung des archaischen Rio das Velhas Grünsteingürtels, Minas Gerais, Brasilien. Terra Nostra, Bonn, Alemanha, v. 2, n. 94, p. 70-71, 1994.

Schwartz, S., Guillot, S., Reynard, B., Lafay, R., Debret, B., Nicollet, C., Lanari, P., Anne Line Auzende, A.L. 2013. Pressure-temperature estimates of the lizardite/antigorite transition in high pressure serpentinites. Lithos, 178: 197-210.

Shackleton, R. M. 1995. Tectonic evolution of greenstone belts The Croft Barn, Church Street, East Hendred, Wantage, Oxon OX12 8LA, UK, Geological Society, London, Special Publications; v. 95; p. 53-65;

Silva, M.G. 1983. A Seqüência Vucanossedimentar do médio Rio Itapicuru, Bahia: Caracterização petrográfica, considerações petrogenéticas preliminares e zoneografia metamórfica. Salvador. 88 p. (Dissertação de Mestrado, IG/UFBa).

Silva, M.G. 1987. Geochemie, Petrologie und Geotektonische Entwicklung Eines Proterozoischen Grunsteingurtels: Rio Itapicuru, Bahia, Brasil. Alemanha. 179 p. (Tese de Doutorado, Geologisches Institui der Universitaet).

Smithies, R.H.; Champion, D.C.; Van Kranendonk, M.J.; Howard, H.W.; Hickman, A.H. 2005.Modern-style subduction processes in the Mesoarchaean: geochemical evidence from the 3.12 GaWhundo intra-oceanic arc. Earth and Planetary Science Letters, 231, 221-237.

Sousa, S.D.; Oliveira, D.C.; Gabriel, E.O.; Macambira, M.J.B. 2010. Geologia, Petrografia e Geocronologia das rochas granitoides do Complexo Xingu da porção a leste da cidade de 
Água Azul do Norte (PA) - PMC. In: SBG, Congresso Brasileiro de Geologia, 45, Anais, Belém, CDrom.

Souza, S.R.B.; Macambira, M.J.B.; Sheller, T. 1996. Novos dados geocronológicos para os granitos deformados do Rio Itacaiúnas (Serra dos Carajás, PA); implicações estratigráficas. In: V Simpósio de Geologia da Amazônia, Belém, Proceedings, pp 380-383

Souza, Z.S. 1994. Geologia e petrogênese do "greenstone belt" Identidade: implicações sobre a evolução geodinâmica do terreno granite-greenstone de Rio Maria, SE do Pará. Ph.D. dissertation, Universidade Federal do Pará, Brazil, 625p

Souza, Z.S.; Potrel A.; Lafon, J.M.; Althoff, F.J.; Pimentel, M.M.; Dall'Agnol R.; Oliveira, C.G. 2001. $\mathrm{Nd}, \mathrm{Pb}$ and $\mathrm{Sr}$ isotopes in the Identidade Belt, an Archaean greenstone belt of the Rio Maria region (Carajás Province, Brazil): implications for the Archaean geodynamic evolution of the Amazonian Craton. Precambrian Research, 109:293-315.

Souza, Z.S.; Santos, A.B.S.; Ledsham, E.J.; Martins, L.P.B.; Huhn, S.R.B.; Costa, V.G. 1988. Feições geológicas e estruturais do "greenstone belt" de Identidade, região de Xinguara- Rio Maria, sul do Pará. In: CONGRESSO BRASILEIRO DE GEOLOGIA, 35., 1988, Belém. Anais... Belém: SBG, v. 3, p. 1453-1467.

Spear, F.S. 1993. Metamorphic phase equilibria and pressure-temperature-time paths. Mineralogical Society of America, Washington, D.C. (1993), 799 pp.

Stern, R.A.; Hanson, G.N. 1991. Archean high-Mg granodiorites: a derivative of light rare earth enriched monzodiorite of mantle origin. Journal of Petrology 32, 201-238.

Streckeisen, A. L. 1976. To each plutonic rock its proper name. Earth Science Review, 12: 133.

Sun, S.; McDonough, W.F. 1989. Chemical and isotopic systematic of oceanic basalts: implications for mantle composition and process. Geological Society London, Special Publication, 42: 313-345.

Sun, S.S.; Bailey, D.K.;Tarney J.; Dunham K. 1980. Lead isotopic study of young volcanic rocks from mid-ocean ridges, ocean islands and island arcs. Philos Trans R Soc London A297, 409-445.

Swanson, S.E. 2008. Magnesiocummingtonite in Metadunites from the Spruce Pine Mining District,Western North Carolina. 2008 Joint Meeting of The Geological Society of America, Soil Science Society of America, American Society of Agronomy, Crop Science Society of America, Gulf Coast Association of Geological Societies with the Gulf Coast Section of SEPM.

Sylvester, P. J., 1989. Post-collisional alkaline granites. Journal of Petrology, 97:261-280.

Szabó, G.A.J. 1996. Petrologia da Suíte Metaultramáfica da Seqüência Vulcano-Sedimentar Morro do Ferro na Região de sul a oeste de Alpinópolis, MG (Domínio Norte do Complexo Campos Gerais). Instituto de Geociências, Universidade de São Paulo, São Paulo, Tese de Doutoramento, $354 \mathrm{p}$.

Tallarico F.H.B., Figueiredo B.R., Groves D.I., Kositcin N., McNaughton N.J., Fletcher I.R., Rego J.L. 2005. Geology and SHRIMP U-Pb geochronology of the Igarapé Bahia deposit, Carajás copper-gold belt, Brazil: an Archean $(2.57 \mathrm{Ga})$ example of iron-oxide $\mathrm{Cu}-\mathrm{Au}-(\mathrm{U}-$ REE) mineralization. Econ Geol 100:7-28.

Tallarico, F.H.B.; Figueiredo, B.R.; Groves, D.I.; Kositcin, N.; McNaughton, N.J.; Fletche,r I.R.; Rego, J.L. 2005. Geology and SHRIMP U-Pb geochronology of the Igarapé Bahia Deposit, Carajás Copper-Gold Belt, Brazil: an Archean $(2.57 \mathrm{Ga})$ example of Iron-Oxide $\mathrm{Cu}-$ Au-(U-REE) Mineralization. Economic Geology, v. 100, n. 1, p. 7-28. 
Tassinari, C.C.G.; Macambira, M.J.B. 1999. A evolução tectônica do Cráton Amazônico. In: (Ed.) Geologia do continente Sul-americano: evolução da obra de Fernando Flávio Marques de Almeida. São Paulo: Beca, p. 471-485.

Tassinari, C.C.G.; Macambira, M.J.B. 2004. A evolução tectônica do Cráton Amazônico. In: Mantesso-Neto, V. et al. (Ed.). Geologia do continente Sul-americano: evolução da obra de Fernando Flávio Marques de Almeida. São Paulo: Beca, p. 471-485.

Tassinari, C.C.G.; Tachibana, J.; Tulio, M.; Livio, R.;Gaia ,C. 2005. Geologia isotópica aplicada nas mineralizações de $\mathrm{Cu}-\mathrm{Au}$ do greenstone belt da Serra dos Gradaús, Província Mineral de Carajás, Cráton Amazônico: exemplo de mineralizações policíclicas. In: Simpósio Brasileiro de Metalogenia, 1., Gramado, RS. Resumos... Porto Alegre: SBG/SEG/ SGMTMMME, 2005. 1 CD-ROM.

Trendall, A.F.; Basei, M.A.S.; Laeter, J.R.; Nelson, D.R. 1998. SHRIMP zircon U-Pb constraints on the age of the Carajás formation, Grão Pará group, Amazon Craton. Journal of South American Earth Sciences 11, 265-277.

Vasquez, M.L.; Rosa-Costa, L.T.; Silva, C.G.; Ricci, P.F.; Barbosa, J.O.; Klein, E.L.; Lopes, E.S.; Macambira, E.B.; Chaves, C.L.; Carvalho, J.M.; Oliveira, J.G.; Anjos, G.C.; Silva, H.R. 2008a. Geologia e Recursos Minerais do Estado do Pará: Sistema de Informações Geográficas - SIG: Texto Explicativo dos Mapas Geológico e Tectônico e de Recursos Minerais do Estado do Pará. Organizadores: M.L. Vasquez, L.T. Rosa-Costa. Escala 1:1.000.000. Belém: CPRM.

Vial, D.S.; Abreu, G.C.; Schubert, G; Ribeiro-Rodrigues, L.C. 2007. Smaller gold deposits in the Archean Rio das Velhas greenstone belt, Quadrilátero Ferrífero, Brazil. Ore Geology Reviews, Volume 32, Issues 3-4, November 2007, Pages 651-673.

Viljoen, M. J.; Viljoen, R.P.; Pearton, T.N. 1982. The nature and distribution of Archean komatiite volcanics in South Africa. In: Arndt, N. T., Nisbet, E. G. (Edit.) Komatiites. London: George Allen \& Unwin, p. 53-79.

Villas, R.N.; Santos, M.D. 2001. Gold deposits of the Carajás mineral province: deposit type and metallogenesis. Mineralium Deposita, 36: 300-331.

Whalen J.W., Currie K.L., Chappel B.W. 1987. A-Type Granites: Geochemical Characteristics, Discrimination And Petrogenesis. Contrib. Mineral. Petrol. 95: 407-419.

Wilson, J.F. 1979. A preliminary reappraisal of the Rhodesian basement complex. Spec. Publ. geol. Soc. S. Afr. 5: 1-23.

Wilson, J.F. 1981. The granitic-gnaiss greenstone shield: Zimbabwe. In: D.R. Hunter, (ed) Precambriam of the Southern Hemisfere. pp 454-488. Elsevier, Amsterdam, 882 pp.

Winter, J.D. 2010. An Introduction to Igneous and Metamorphic Petrology. Prentice Hall PTR, 2010 - Science - 702 pp.

Xavier, R.P., Monteiro, L.V.S., Moreto, C.P.N., Pestilho, A.L.S., Melo, G.H.C., Silva, M.A.D. da; Aires, B., Ribeiro, C., Freitas e Silva, F.H. 2012. The Iron Oxide Copper-Gold systems of the Carajas Mineral Province. In: J. Hedenquist, M. Harris, F. Camus. (Org.). SEG Special Publication 16, Geology and Genesis of Major Copper Deposits and Districts of the World: A Tribute to Richard H. Sillitoe. 1ed. Littleton: Society of Economic Geologists, 1: 433-454. 


\section{Apêndice}




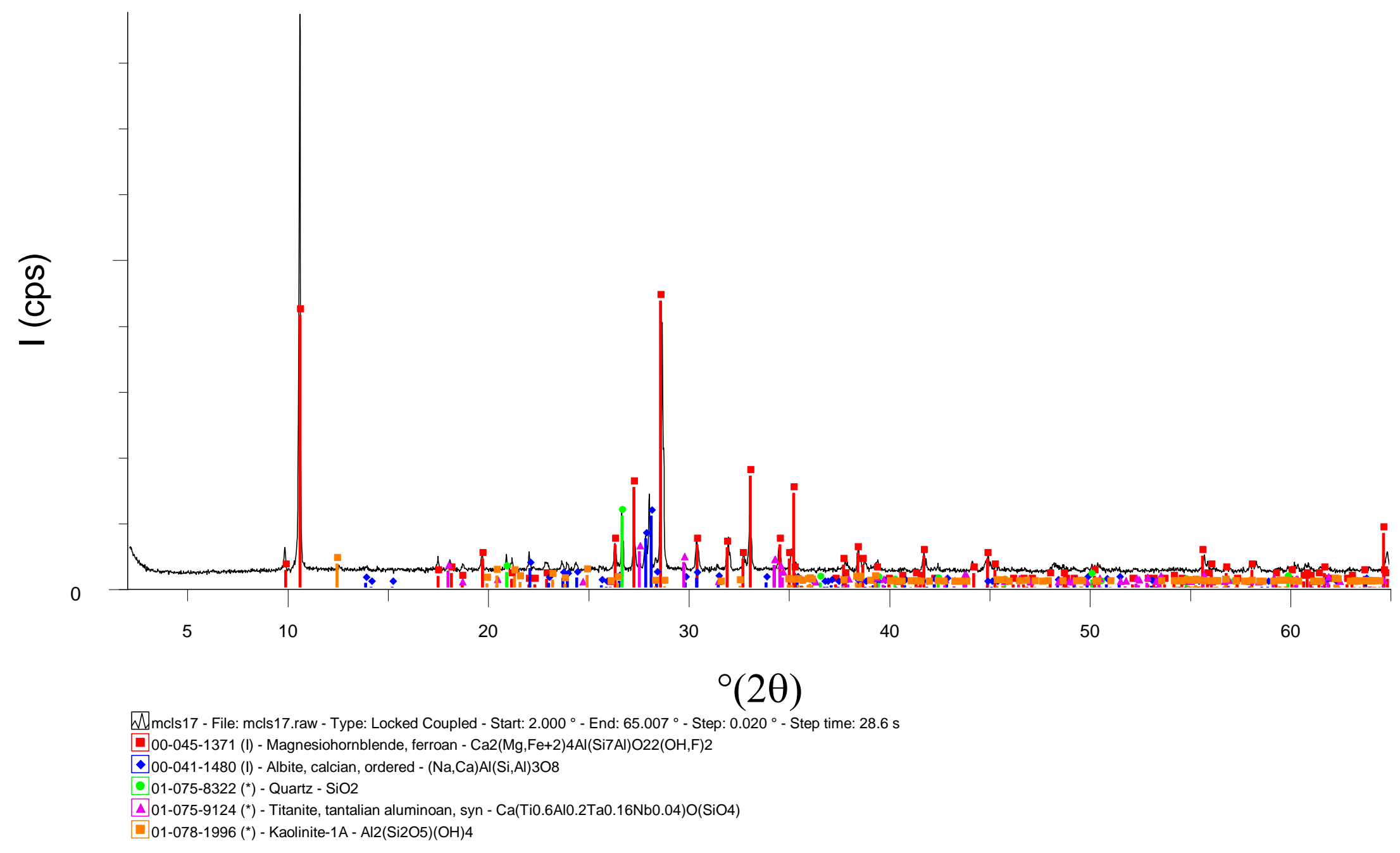




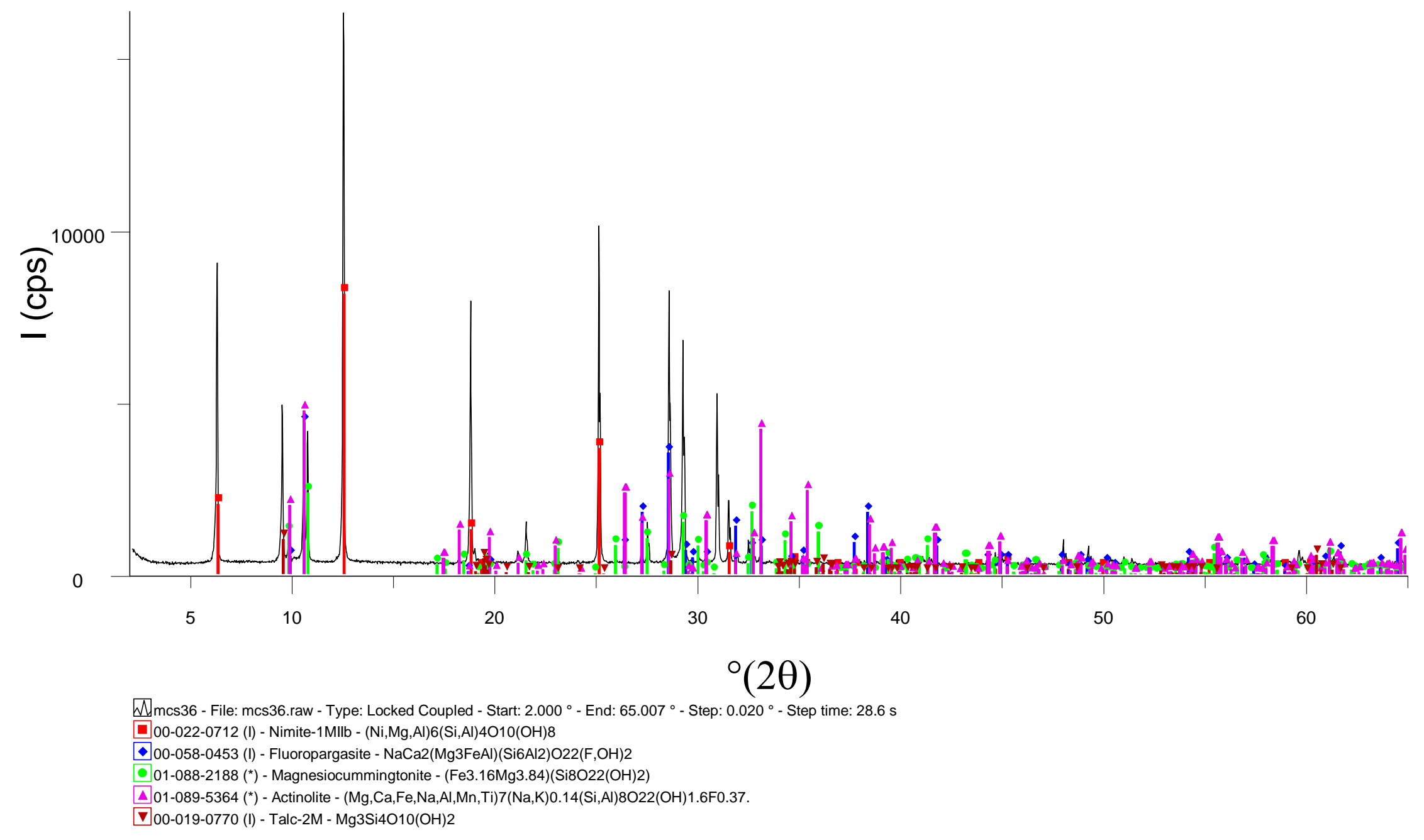


Apêndice 3. Gráfico de difratometria de raios X da amostra MCLS 19a

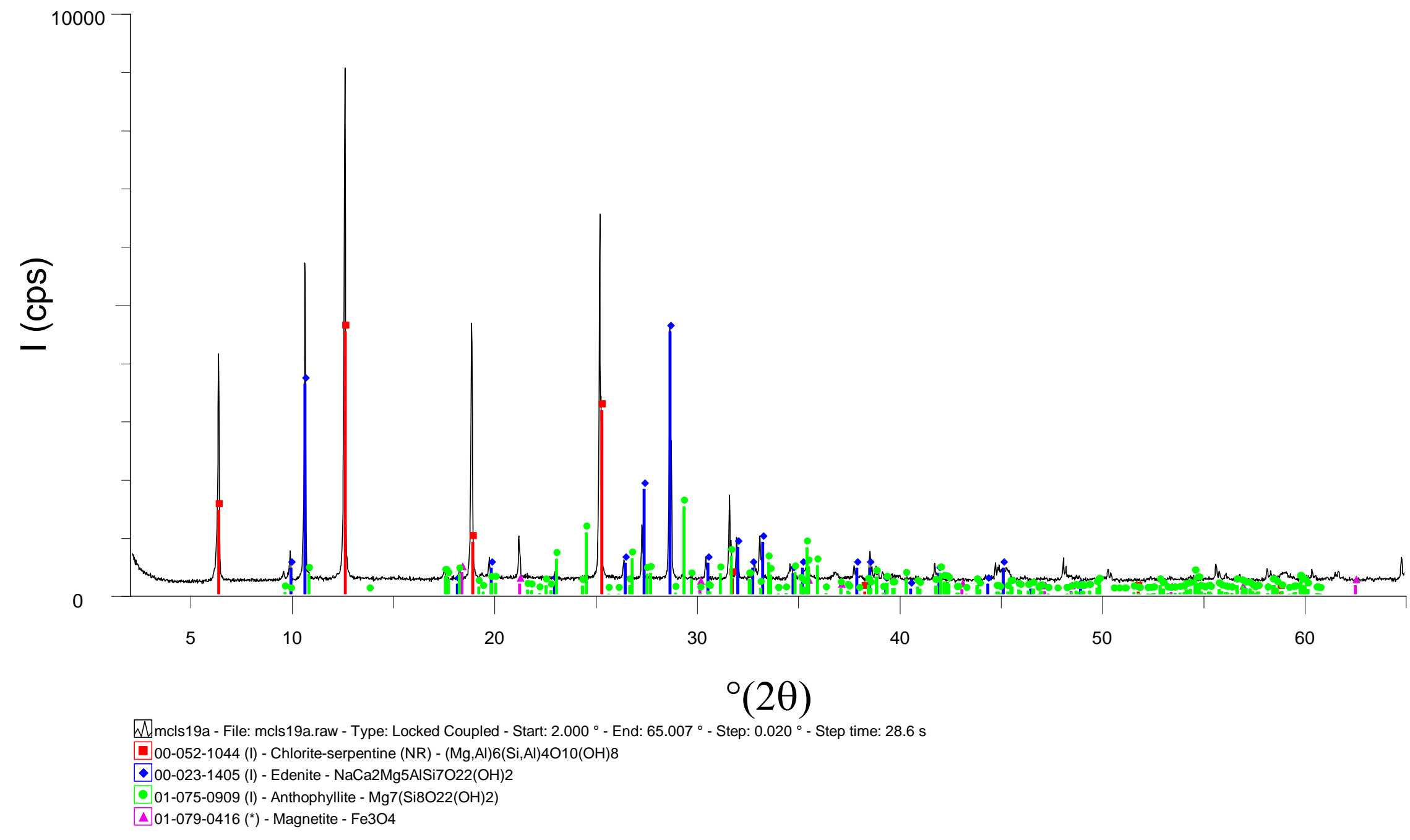


Apêndice 4. Gráfico de difratometria de raios X da amostra MCS 11

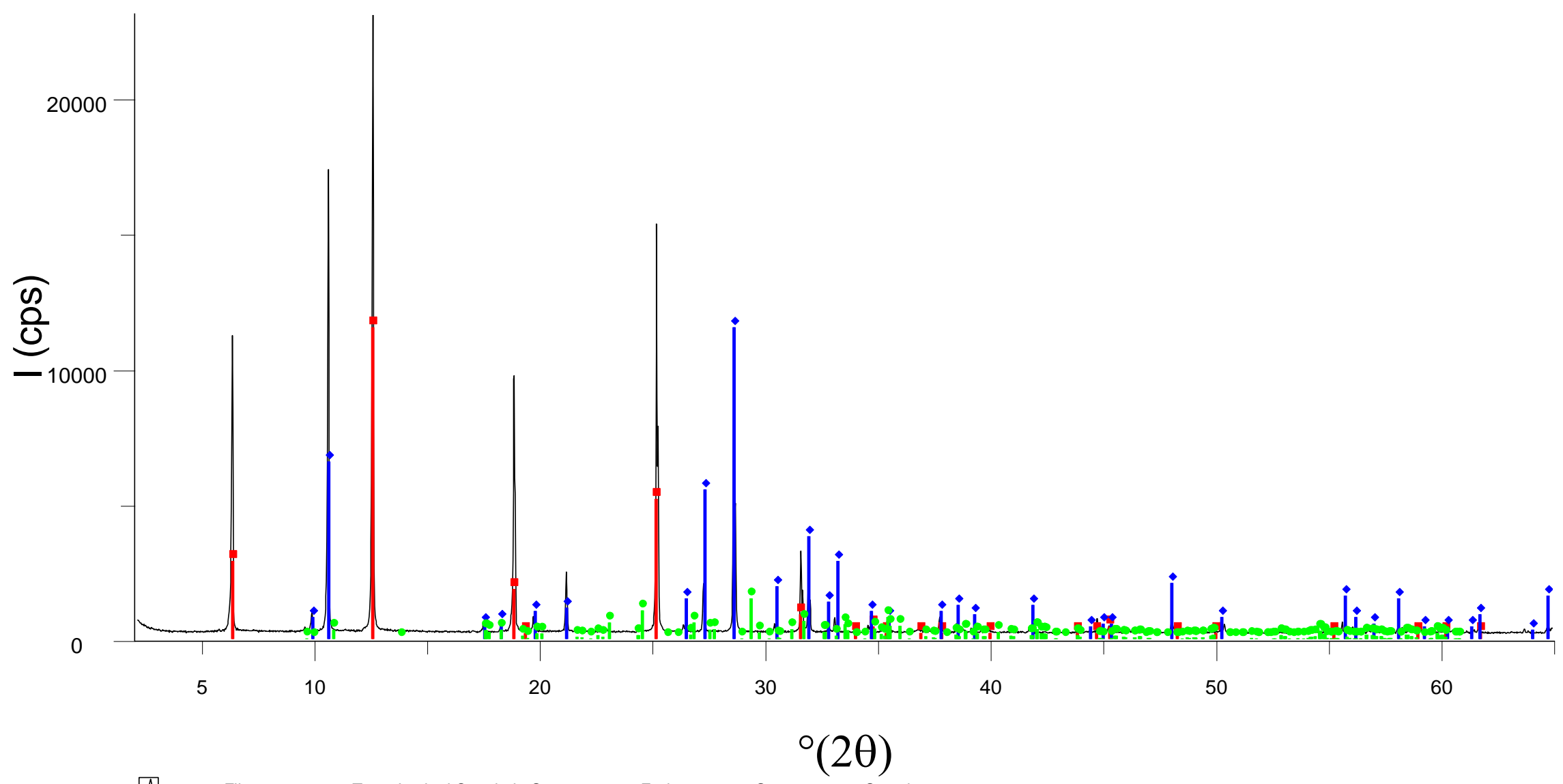

Mmcs11 - File: mcs11.raw - Type: Locked Coupled - Start: $2.000^{\circ}$ - End: $65.007^{\circ}$ - Step: $0.020^{\circ}$ - Step time: 28.6 s 00-022-0712 (I) - Nimite-1Mllb - (Ni,Mg,Al)6(Si,Al)4O10(OH)8

00-054-0748 (I) - Fluoro-edenite - NaCa2Mg5(Si7Al)O22F2

01-075-0909 (I) - Anthophyllite - Mg7(Si8O22(OH)2) 


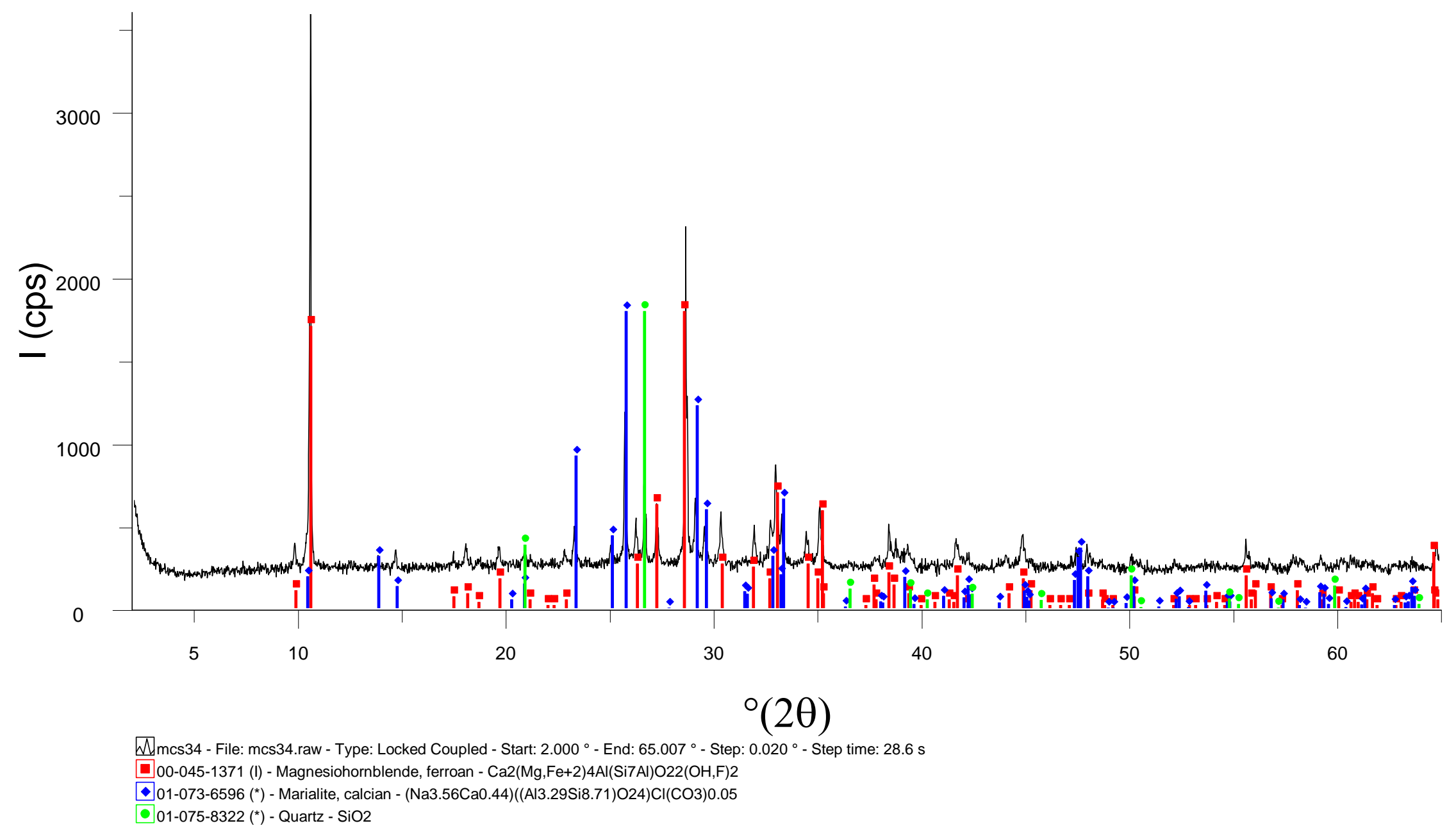




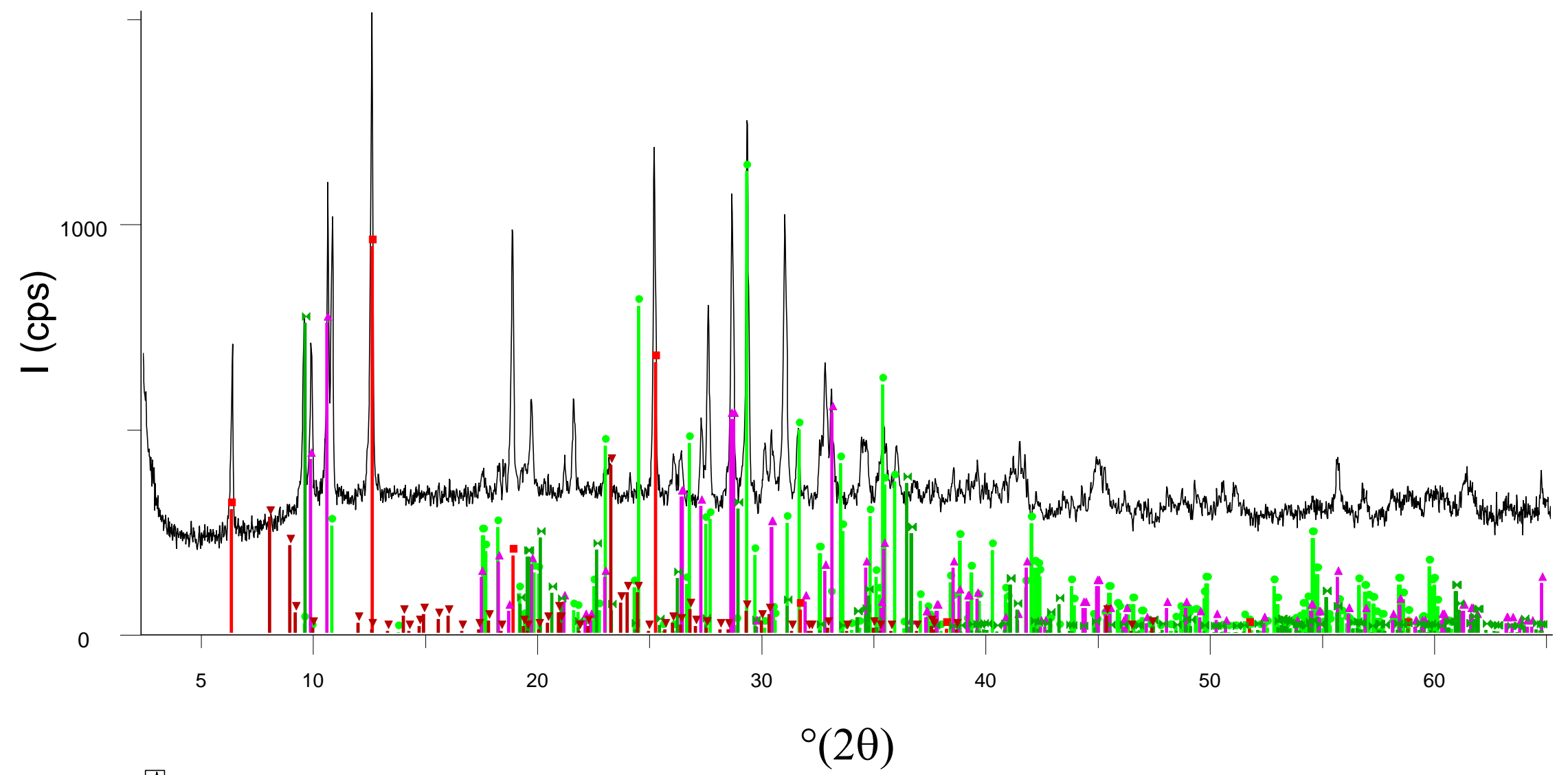

Whmcs35 - File: mcs35.raw - Type: Locked Coupled - Start: $2.314^{\circ}$ - End: $65.271^{\circ}$ - Step: $0.020^{\circ}$ - Step time: $28.6 \mathrm{~s}$ 01-075-0909 (I) - Anthophyllite - Mg7(Si8O22(OH)2)

- 00-052-1044 (I) - Chlorite-serpentine (NR) - (Mg,Al)6(Si,Al)4O10(OH)8

$\triangle$ 00-044-1402 (I) - Tremolite - Ca2Mg5Si8O22(OH)2

$\nabla$ 00-044-0002 (I) - Mutinaite, syn - Al2O3.54SiO2

01-074-1036 (I) - Talc-2M - Mg3Si4O10(OH)2 
Apêndice 7. Gráfico de difratometria de raios X da amostra MCLS 25

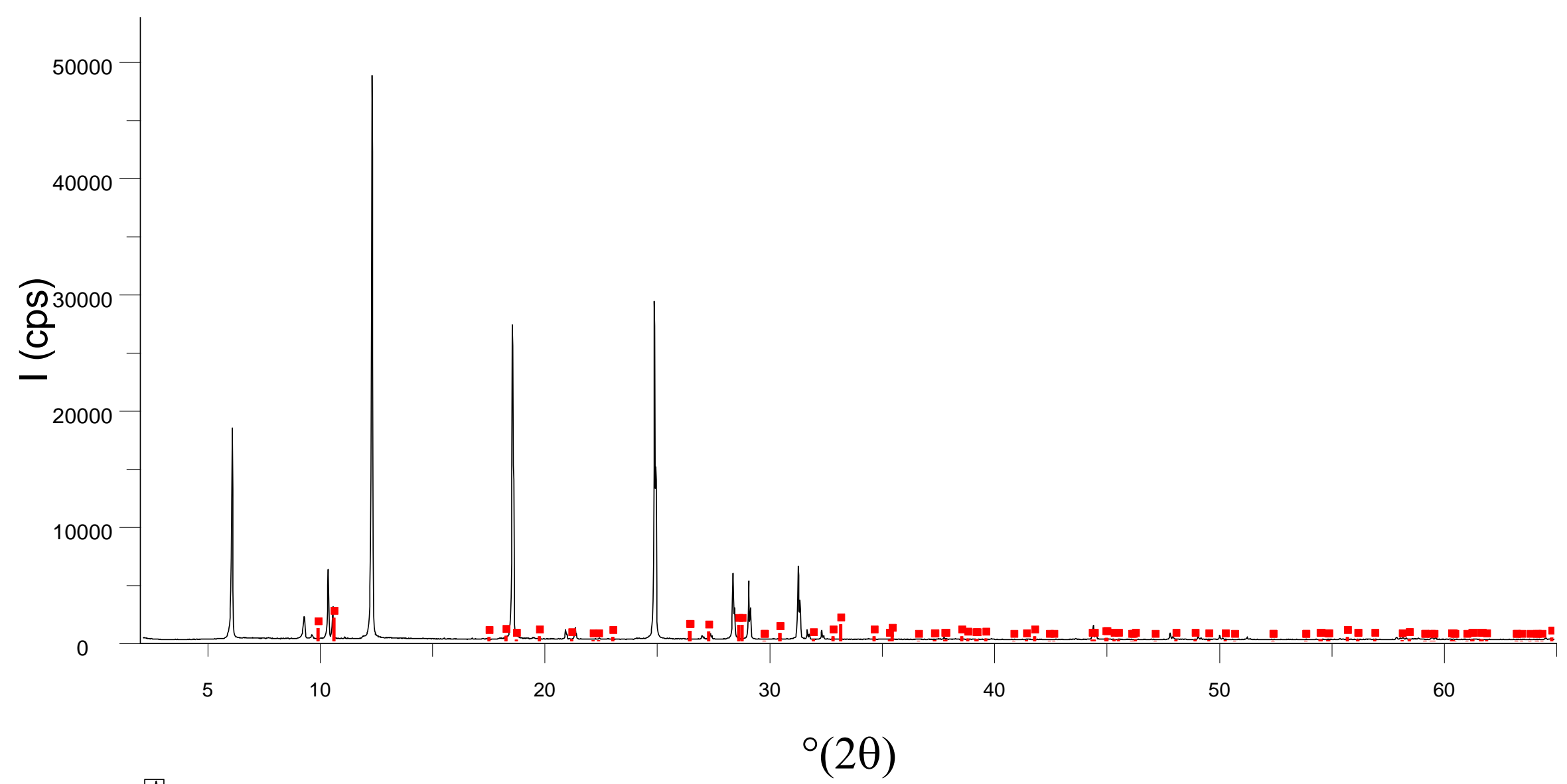

WMCLS25 - File: MCLS25.raw - Type: Locked Coupled - Start: $2.000^{\circ}$ - End: $65.007^{\circ}$ - Step: $0.020^{\circ}$ - Step time: $28.6 \mathrm{~s}$ $\square$ 00-044-1402 (I) - Tremolite - Ca2Mg5Si8O22(OH)2 


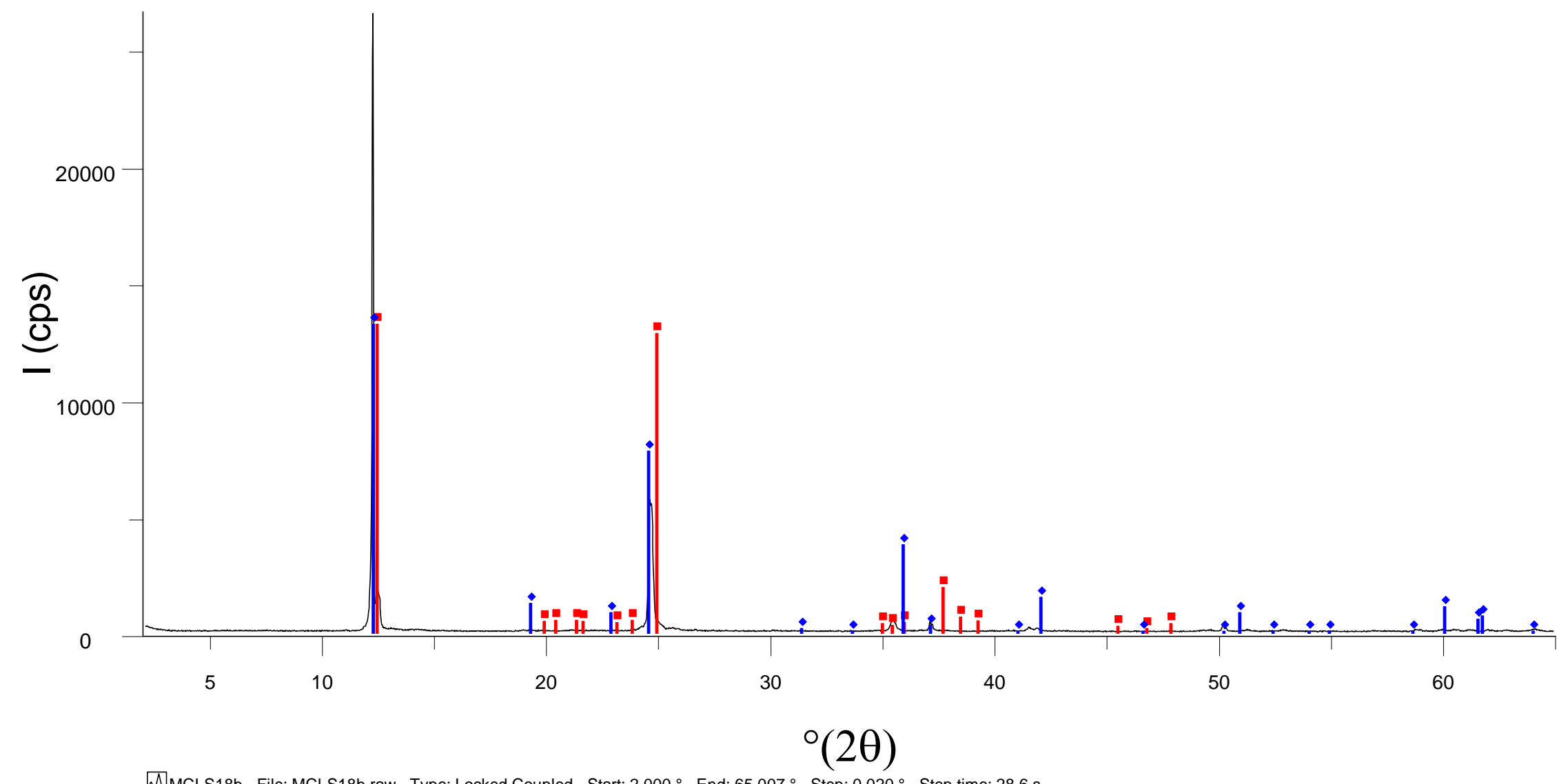

WMCLS18b - File: MCLS18b.raw - Type: Locked Coupled - Start: $2.000^{\circ}$ - End: $65.007^{\circ}$ - Step: $0.020^{\circ}$ - Step time: $28.6 \mathrm{~s}$ 00-058-2004 (I) - Kaolinite-1A - Al2Si2O5(OH)4

00-050-1625 (I) - Lizardite-1T - (Mg.Al)3((Si,Fe)2O5)(OH)4 
Apêndice 9. Gráfico de difratometria de raios X da amostra MCLS 18d

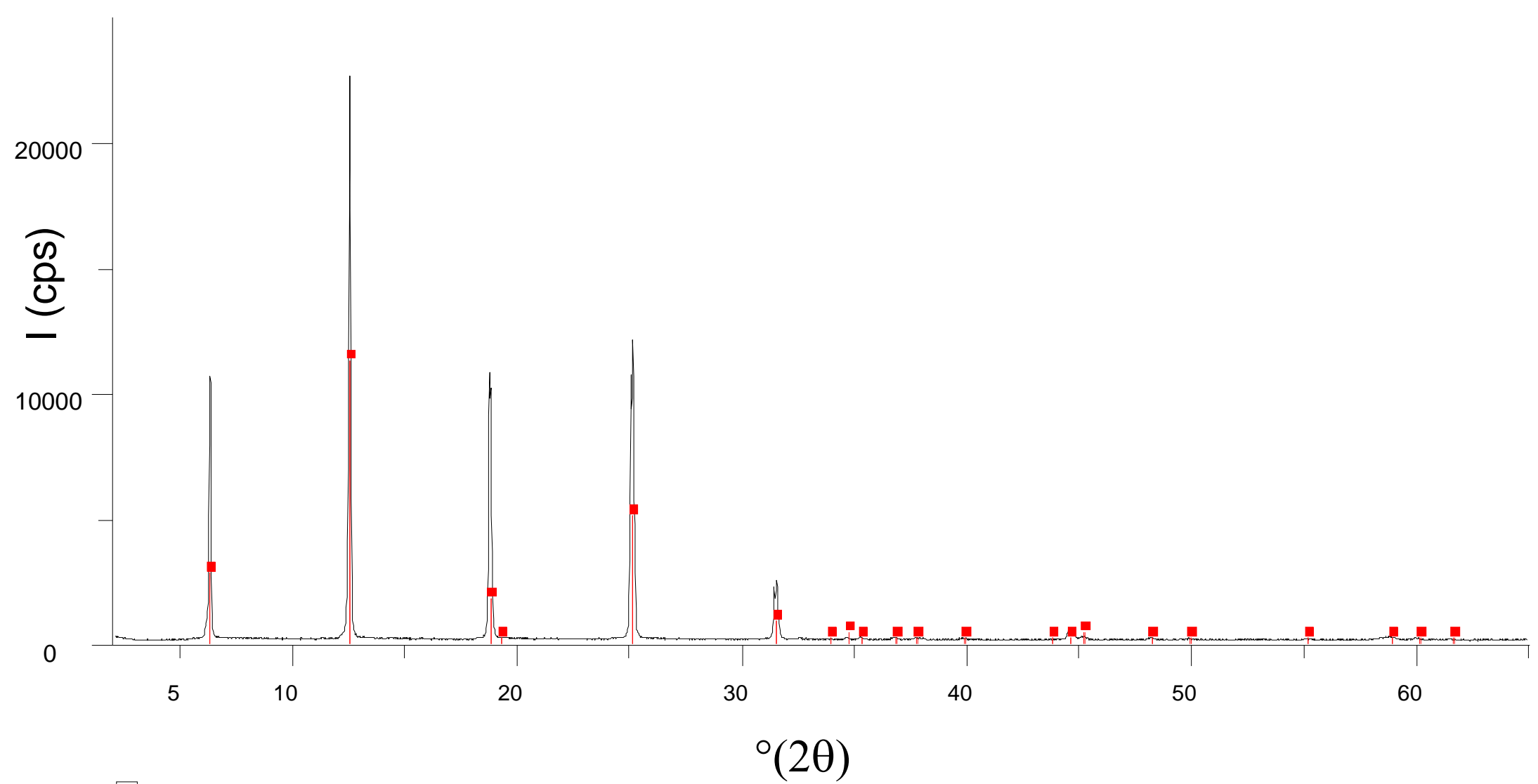

MMCLS18d - File: MCLS18a.raw - Type: Locked Coupled - Start: $2.000^{\circ}$ - End: $65.007^{\circ}$ - Step: $0.020^{\circ}$ - Step time: $28.6 \mathrm{~s}$ 00-022-0712 (I) - Nimite-1Mllb - (Ni,Mg,Al)6(Si,Al)4O10(OH)8 
Apêndice 10. Tabela dos dados geoquímicos analisados.

\begin{tabular}{|c|c|c|c|c|c|c|c|c|c|c|c|c|c|c|c|c|c|c|}
\hline & & & & & ME & AULTI & AMÁF & CAS & & & & & $\mathbf{M E}$ & ABÁSIC & AS & DIAF & ÁSIO & $\begin{array}{c}\text { METAPE } \\
\text { LÍTICA }\end{array}$ \\
\hline & $\begin{array}{c}\text { MCLS } \\
18 \mathrm{~d}\end{array}$ & $\begin{array}{c}\text { MCLS } \\
18 \mathrm{~b}\end{array}$ & $\begin{array}{c}\text { MCLS } \\
25\end{array}$ & $\begin{array}{c}\text { MCS } \\
08\end{array}$ & $\begin{array}{c}\text { MCS } \\
11\end{array}$ & $\begin{array}{c}\text { MCS } \\
16\end{array}$ & $\begin{array}{c}\text { MCS } \\
10\end{array}$ & $\begin{array}{c}\text { MCS } \\
35\end{array}$ & $\begin{array}{c}\text { MCS } \\
30 \mathrm{~b}\end{array}$ & $\begin{array}{c}\text { MCS } \\
36\end{array}$ & $\begin{array}{c}\text { MCS } \\
38 \mathrm{a}\end{array}$ & $\begin{array}{c}\text { MCS } \\
42\end{array}$ & $\begin{array}{c}\text { MCS } \\
20\end{array}$ & $\begin{array}{c}\text { MCLS } \\
17\end{array}$ & $\begin{array}{c}\text { MCS } \\
38 b\end{array}$ & $\begin{array}{c}\text { MCS } \\
22\end{array}$ & $\begin{array}{c}\text { MCLS } \\
12\end{array}$ & \\
\hline $\mathrm{SiO} 2(\%)$ & 27,66 & 41,44 & 45,83 & 49,30 & 46,95 & 46,94 & 43,18 & 49,02 & 49,75 & 43,06 & 45,93 & 39,28 & 52,67 & 49,81 & 47,95 & 49,79 & 52,82 & 74,88 \\
\hline $\mathrm{TiO} 2$ & 2,76 & 0,02 & 0,18 & 0,21 & 0,42 & 0,41 & 0,53 & 0,36 & 0,45 & 0,46 & 0,52 & 0,08 & 0,30 & 0,90 & 0,39 & 0,92 & 0,79 & 0,44 \\
\hline $\mathrm{Al} 2 \mathrm{O} 3$ & 17,14 & 0,56 & 8,21 & 5,55 & 6,08 & 7,07 & 9,71 & 4,7 & 4,58 & 4,83 & 7,56 & 1,99 & 5,41 & 14,00 & 18,23 & 14,34 & 14,15 & 11,9 \\
\hline $\mathrm{Fe} 2 \mathrm{O} 3$ & 12,93 & 8,94 & 8,59 & 11,51 & 11,80 & 11,80 & 14,20 & 11,29 & 10,97 & 12,55 & 12,81 & 8,88 & 10,11 & 13,14 & 7,58 & 12,7 & 12,13 & 3,76 \\
\hline $\mathrm{MnO}$ & 0,08 & 0,06 & 0,14 & 0,17 & 0,16 & 0,18 & 0,17 & 0,17 & 0,24 & 0,21 & 0,18 & 0,15 & 0,21 & 0,23 & 0,12 & 0,20 & 0,19 & 0,07 \\
\hline $\mathrm{MgO}$ & 25,82 & 35,77 & 25,50 & 18,98 & 20,75 & 20,41 & 19,29 & 21,56 & 22,1 & 22,55 & 19,57 & 34,13 & 16,14 & 7,69 & 9,26 & 8,23 & 6,34 & 1,34 \\
\hline $\mathrm{CaO}$ & 1,12 & 0,01 & 4,10 & 9,32 & 8,61 & 9,81 & 6,65 & 7,66 & 6,65 & 6,5 & 7,98 & 0,65 & 12,18 & 10,37 & 13,72 & 11,55 & 10,34 & 1,61 \\
\hline $\mathrm{Na} 2 \mathrm{O}$ & 0,01 & 0,01 & 0,05 & 0,18 & 0,13 & 0,32 & 0,23 & 0,10 & 0,06 & 0,04 & 0,32 & 0,01 & 1,06 & 2,20 & 1,31 & 1,72 & 1,96 & 2,94 \\
\hline $\mathrm{K} 2 \mathrm{O}$ & 0,01 & 0,01 & 0,01 & 0,01 & 0,01 & 0,02 & 0,01 & 0,01 & 0,01 & 0,01 & 0,01 & 0,01 & 0,22 & 0,25 & 0,16 & 0,08 & 0,7 & 1,23 \\
\hline $\mathrm{P} 2 \mathrm{O} 5$ & 0,86 & 0,01 & 0,01 & 0,02 & 0,01 & 0,02 & 0,05 & 0,01 & 0,03 & 0,02 & 0,02 & 0,02 & 0,06 & 0,07 & 0,03 & 0,07 & 0,11 & 0,07 \\
\hline $\mathrm{Cr} 2 \mathrm{O} 3$ & 0,05 & 0,76 & 0,41 & 0,25 & 0,28 & 0,26 & 0,31 & 0,25 & 0,27 & 0,22 & 0,20 & 0,23 & 0,22 & 0,05 & 0,13 & 0,03 & 0,02 & 0,02 \\
\hline Total & 88,44 & 87,59 & 93,03 & 95,50 & 95,20 & 97,24 & 94,33 & 95,13 & 95,11 & 90,45 & 95,10 & 85,43 & 98,58 & 98,71 & 98,88 & 99,63 & 99,55 & 98,26 \\
\hline $\mathrm{Ni}(\mathrm{ppm})$ & 581 & 3162 & 1022 & 750 & 1127 & 1184 & 746 & 1046 & 666 & 1639 & 833 & 2615 & 193 & 133 & 158 & 126 & 62 & 26 \\
\hline $\mathrm{Y}$ & 50 & 0,4 & 8,2 & 84,6 & 12,1 & 10,5 & 33,4 & 32,2 & 54,2 & 18,1 & 88,7 & 1,2 & 9,6 & 20,0 & 8,3 & 19,1 & 19,9 & 8 \\
\hline $\mathrm{Co}$ & 123,4 & 97,1 & 60 & 64,4 & 76 & 98,6 & 77,5 & 82,0 & 85,4 & 92,7 & 69,2 & 100,8 & 59,9 & 65,5 & 47,9 & 66,1 & 58,8 & 26,1 \\
\hline V & 390 & 36 & 122 & 119 & 150 & 135 & 195 & 134 & 159 & 119 & 146 & 50 & 167 & 312 & 162 & 286 & 220 & 65 \\
\hline $\mathrm{Ga}$ & 10,3 & 1,3 & 7,4 & 5,9 & 7,6 & 7,7 & 10,9 & 6,2 & 7,4 & 5,9 & 8,7 & 3,0 & 8,8 & 16,1 & 14 & 16,2 & 16,4 & 12,4 \\
\hline $\mathrm{Cu}$ & 0,2 & 0,2 & 54 & 27,2 & 115,3 & 95,8 & 2,4 & 24,3 & 477,4 & 11,2 & 53,5 & 21,4 & 0,5 & 157,7 & 13 & 100,7 & 95,7 & 26,2 \\
\hline $\mathrm{Zn}$ & 34 & 14 & 11 & 40 & 10 & 8 & 21 & 19 & 23 & 25 & 35 & 20 & 4 & 22 & 2 & 16 & 16 & 34 \\
\hline $\mathrm{Rb}$ & 0,1 & 0,5 & 1,1 & 0,2 & 0,4 & 1,3 & 1,4 & 0,4 & 2,0 & 0,7 & 0,6 & 0,3 & 6,6 & 3,7 & 2,2 & 2,3 & 24,9 & 47,8 \\
\hline $\mathrm{Sr}$ & 25,9 & 0,5 & 4,6 & 5,6 & 7,0 & 63,5 & 4,5 & 10,8 & 6,7 & 60,5 & 9,5 & 3,5 & 177,1 & 125,5 & 258,8 & 101,4 & 118,5 & 337,9 \\
\hline $\mathrm{Zr}$ & 246 & 2,1 & 15,1 & 11,1 & 23,6 & 28,1 & 38,5 & 21,5 & 27,7 & 24,4 & 27,6 & 4,9 & 30,6 & 50,9 & 21 & 51,9 & 79,6 & 113 \\
\hline $\mathrm{Nb}$ & 9,2 & 0,1 & 0,3 & 0,3 & 19,2 & 13,2 & 4,5 & 4,3 & 4,8 & 3,2 & 3,3 & 2,0 & 9,5 & 1,7 & 2,2 & 6,7 & 3,0 & 4,8 \\
\hline Cs & 0,1 & 0,1 & 0,1 & 0,1 & 0,1 & 0,1 & 0,2 & 0,1 & 0,1 & 0,1 & 0,1 & 0,2 & 0,1 & 0,1 & 0,3 & 0,3 & 0,9 & 3,5 \\
\hline $\mathrm{Ba}$ & 101 & 10 & 5 & 4 & 23 & 26 & 3 & 3 & 22 & 16 & 5 & 25 & 90 & 65 & 17 & 28 & 183 & 392 \\
\hline
\end{tabular}




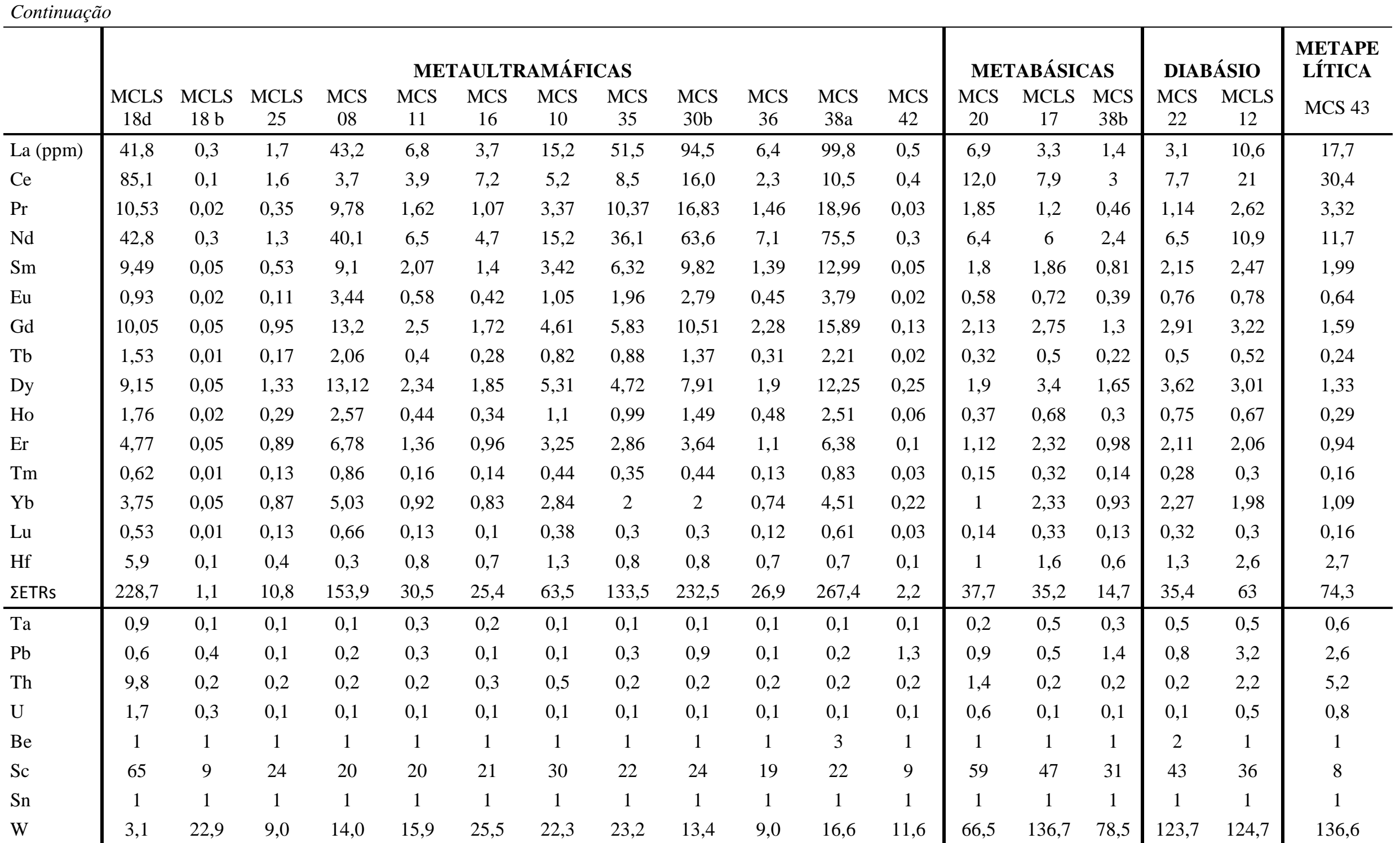




\section{Anexos}

